\title{
SOLAR HEAT WORLDWIDE
}

Global Market Development and Trends in 2017 | Detailed Market Figures 2016

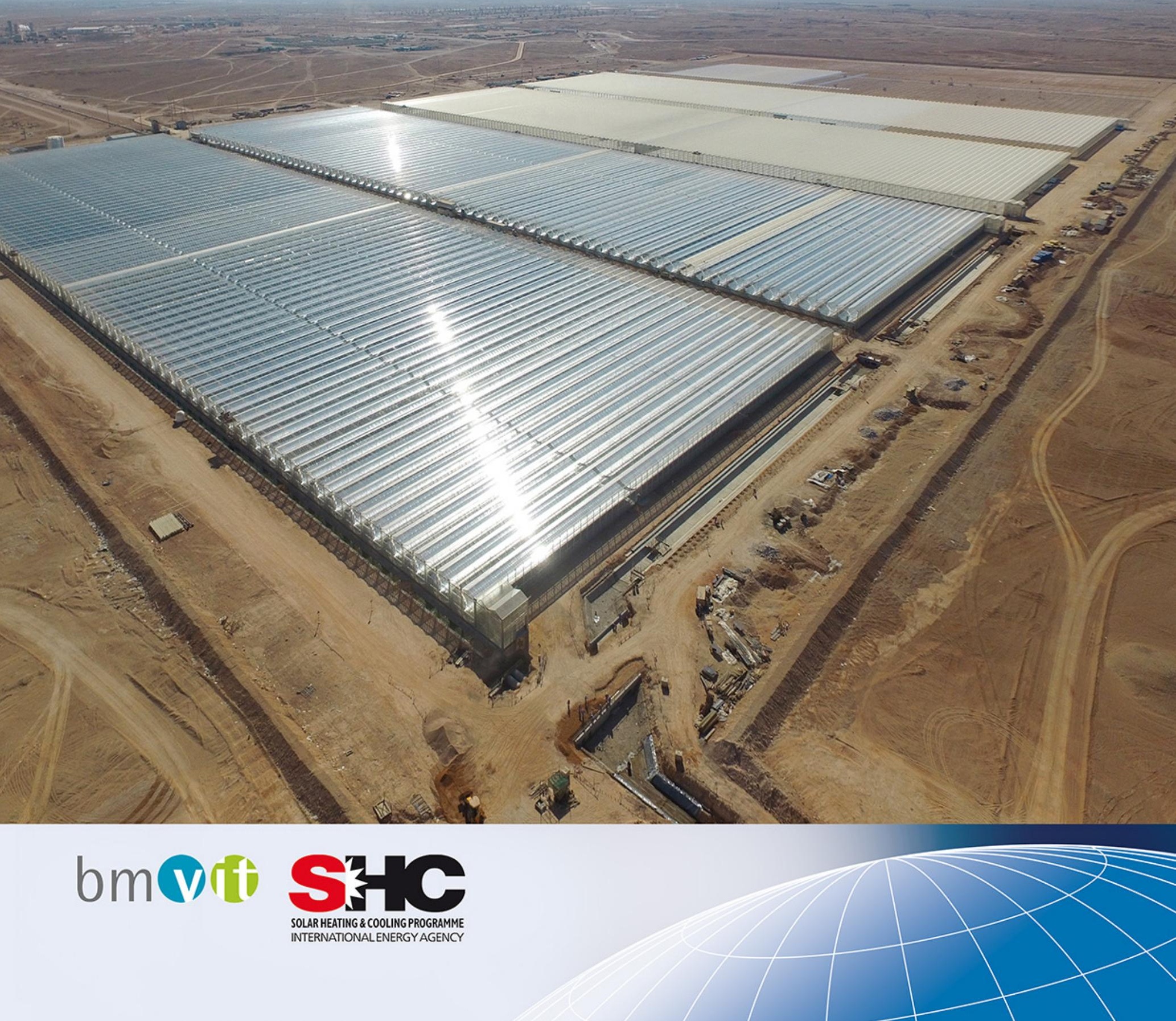





\section{SOLAR HEAT WORLDWIDE}

Global Market Development and Trends in 2017

Detailed Market Figures 2016

2018 EDITION

Werner Weiss, Monika Spörk-Dür

AEE INTEC

AEE - Institute for Sustainable Technologies

8200 Gleisdorf, Austria

AEE INTEC

IEA Solar Heating \& Cooling Programme, May 2018

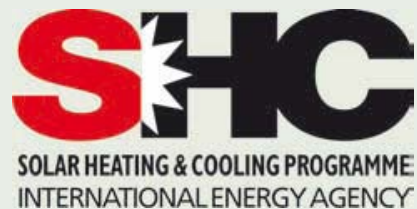

Supported by the Austrian Ministry for Transport, Innovation and Technology

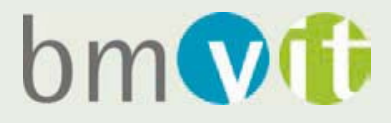

Cover Photo: Barbara Soldera, GlassPoint Solar, Inc.

Design, prepress and web version: STEINHUBER INFODESIGN, Graz, Austria

Notice:

The Solar Heating and Cooling Programme functions within a framework created by the International Energy Agency (IEA). Views, findings and publications of the Solar Heating and Cooling Programme do not necessarily represent the views or policies of the IEA Secretariat or of all its individual member countries. 
The authors would like to give special thanks to the following contributors to this edition of the Solar Heat Worldwide Report:

Chapter 4.2: Large-scale Systems for Solar District Heating and Large Residential, Commercial and Public Buildings

\section{Prof. Jan-Olof Dalenbäck}

Chalmers University of Technology, Sweden

Chapter 4.3: Solar Heat for Industrial Applications

\section{Bärbel Epp}

Solrico, Germany

\section{Wolfgang Glatzl}

AEE INTEC, Austria

\section{Bärbel Epp}

Solrico, Germany

Chapter 4.4: Solar Air Conditioning and Cooling

\section{Dr. Christian Holter}

S.O.L.I.D. GmbH, Austria

\section{Dr. Daniel Mugnier}

TECSOL SA., France

We also very much appreciate the long-term co-operation with all national delegates of the IEA SHC Executive Committee and other national experts, who provide the updated solar thermal market data from 66 countries around the globe every year. All these contributors are listed in the appendix of this report.

Last but not least, the authors would like to thank Pamela Murphy for her feedback, ideas for improvement and proofreading of the report. 


\section{Table of Contents}

1

Background

Summary

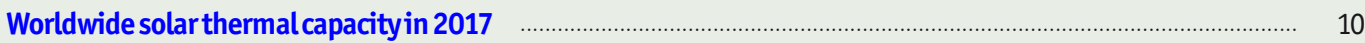

Solar thermal capacity in relation to the capacity of other renewable energy technologies ….................................. 11

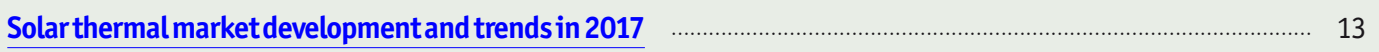

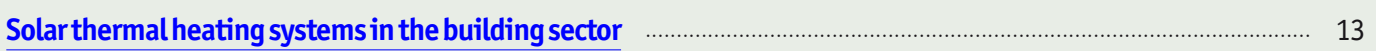

Large-scale systems for the supply of residential, commercial and public buildings …..................................... 13

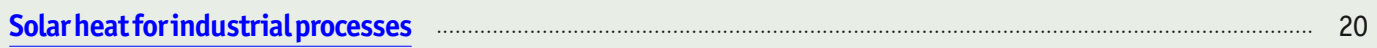

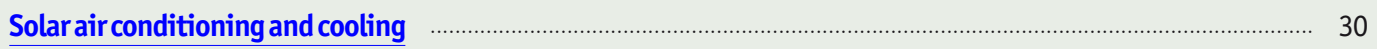

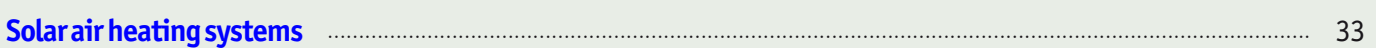

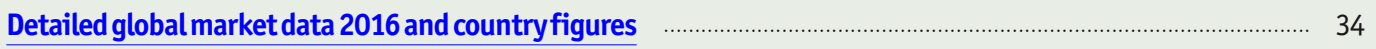

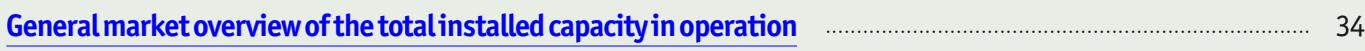

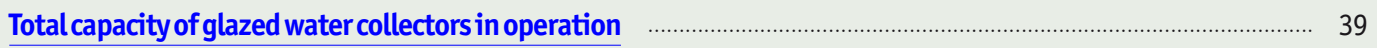

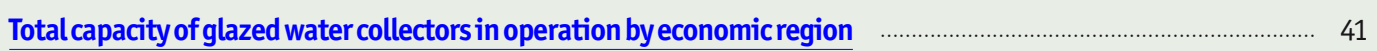

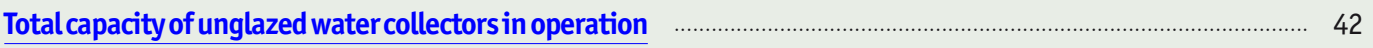

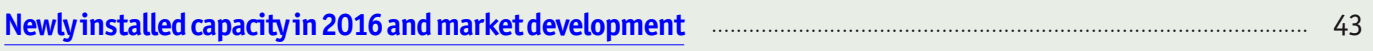

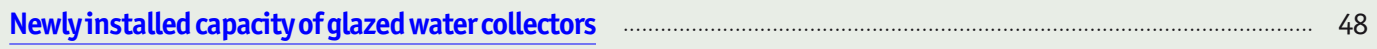

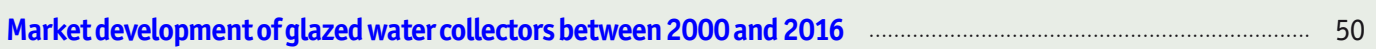

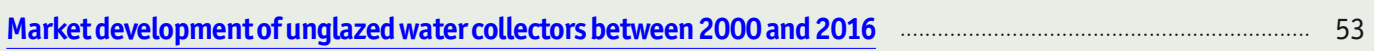

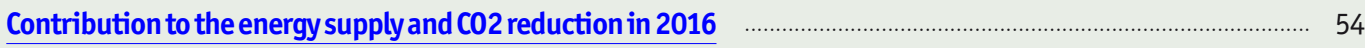

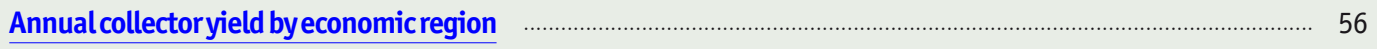

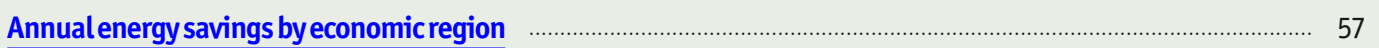

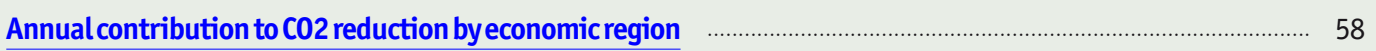

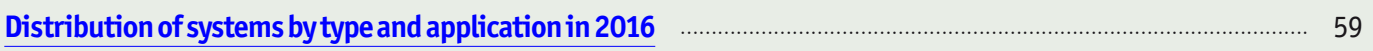

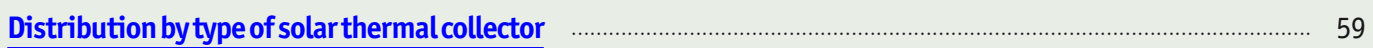

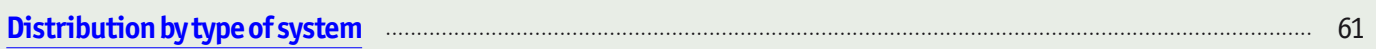

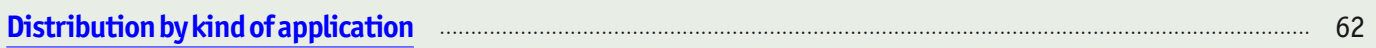

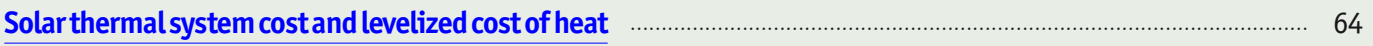

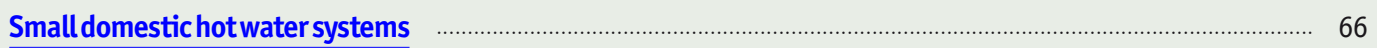

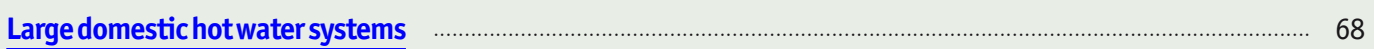

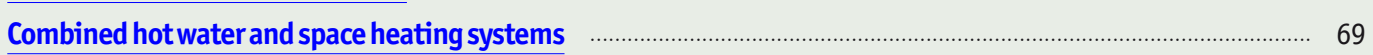

Swimming pool heating systems

Appendix

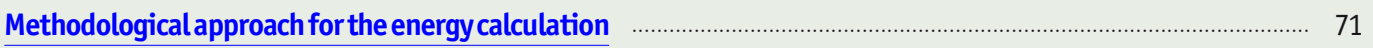

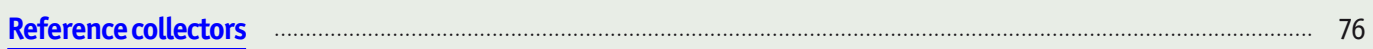

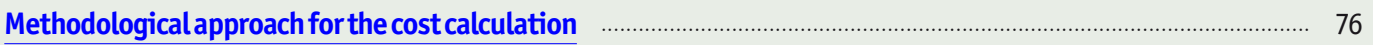

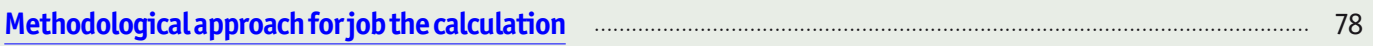

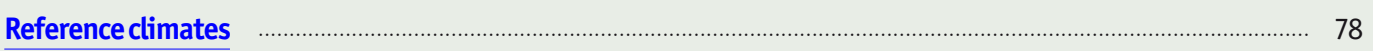

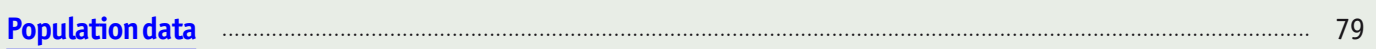

Market data of the previous years

References to reports and persons that have supplied the data

List of Figures

List of Tables 
The report was prepared within the framework of the Solar Heating and Cooling Programme (SHC) of the International Energy Agency (IEA). The goal of the report is to give an overview of the general trends, to highlight special applications and outstanding projects and to document the solar thermal capacityinstalled in the important markets worldwide. Furthermore, it is the goal to ascertain the contribution of solar thermal systems to the supply of energy and the $\mathrm{CO}_{2}$ emissions avoided as a result of operating these systems. The collectors documented in detail are unglazed collectors, glazed flat-plate collectors (FPC) and evacuated tube collectors (ETC) with water as the energy carrier as well as glazed and unglazed air collectors.

This edition of Solar Heat Worldwide includes for the first time an overview of concentrating solar collectors, which are applied in district heating and for industrial processes.

The data were collected from a survey of the national delegates of the IEA SHC Executive Committee and other national experts active in the field of solar thermal energy. As some of the 66 countries included in this report have very detailed statistics and others have only estimates from experts, the data was checked for its plausibility on the basis of various publications.

The collector area, also referenced as the installed capacity, served as the basis for estimating the contributions of solar thermal systems to the energy supply and reductions of $\mathrm{CO}_{2}$ emissions.

The 66 countries included in this report represent 4.8 billion people, or about $66 \%$ of the world's population. The installed capacity in these countries is estimated to represent $95 \%$ of the solar thermal market worldwide.

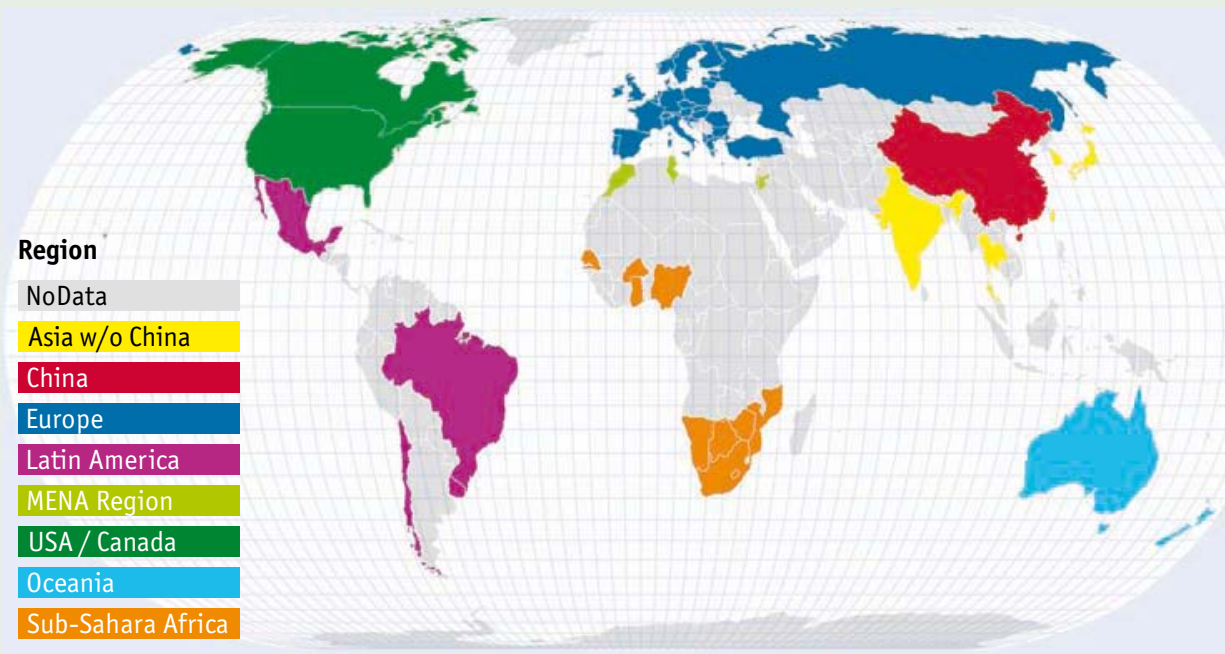

Figure 1: $\quad$ Countries shown in color have detailed market data. Countries shown in grey have estimated market data. 
This report is split into two parts. The first part (Chapters 3 - 4) gives an overall overview of the global solar thermal market development in 2017. In addition, general trends are described and detailed 2017 data on successful applications, such as solar assisted district heating and solar heat for industrial processes, are documented.

The second part (Chapters 5 - 8) presents detailed market figures for the year 2016 from 66 countries around the globe. The concluding chapter of the second part is focused on solar thermal system cost and levelized cost of solar heat for different applications and regions worldwide.

\section{Global solar thermal market developments and status in 2017}

The cumulated solar thermal capacity in operation by end of 2017 was $472 \mathrm{GW}_{\text {th }}$ (675 million square meters). Compared to the year 2000 the installed capacity grew by the factor 7.6.

The corresponding annual solar thermal energy yield in 2017 amounted to 388 TWh, which correlates to savings of 41.7 million tons of oil and 134.7 million tons of $\mathrm{CO}_{2}$.

Despite these achievements, the global solar thermal market has faced challenging times in recent years. This is especially evident in the large markets in China and Europe where the traditional mass markets for small-scale solar water heating systems for singlefamily houses and apartment buildings are under market pressure from heat pumps and photovoltaic systems.

In total, the global market declined by $4.2 \%$ in 2017. Positive market developments were recorded in India (26\%), Mexico (7\%), and in Turkey ( $4 \%)$.

In contrast to the small-scale solar water heating systems, the megawatt-scale solar supported districtheating systems and industrial applications have gained increasing interest all over the world in recent years and several ambitious projects have been successfully implemented.

By the end of 2017 about 300 large-scale solar thermal systems $\left(>350 \mathrm{~kW}\right.$ th; $\left.500 \mathrm{~m}^{2}\right)$ connected to district heating networks and in residential buildings were in operation. The total installed capacity of these systems equaled $1,140 \mathrm{MW}_{\mathrm{th}}\left(1,630,415 \mathrm{~m}^{2}\right)$, excluding concentrating systems that add $110,929 \mathrm{~m}^{2}$.

In 2017, nine large-scale solar thermal systems with about 35,000 $\mathrm{m}^{2}\left(24.5 \mathrm{MW}_{\text {th }}\right)$ were installed in Europe. Outside Europe, $5.9 \mathrm{MW}_{\text {th }}\left(8,444 \mathrm{~m}^{2}\right)$ were installed and one concentrating system in Tibet with a collector area of $9,000 \mathrm{~m}^{2}$. About $75 \%$ of the new collector area installed in Europe is from two new large systems in Denmark and three extensions added to Danish systems. About $92 \%$ of the installed capacity installed outside Europe has been installed in China.

The world's largest plant for solar district heating is located in Silkeborg, Denmark and has an installed capacity of $110 \mathrm{MW}_{\text {th }}$ (156,694 $\mathrm{m}^{2}$ flat plate collectors). The start of operation of this plant was in December 2016. 
Important to note is that in 2016 and 2017 three parabolic trough collector fields were installed for feeding into district heating networks in Denmark and China. The concentrating collector area of these three systems installed adds up to $110,929 \mathrm{~m}^{2}$.

Solar heat for industrial processes (SHIP) continues to be a growing market. A number of promising projects have been implemented in the last couple of years ranging from small-scale demonstration plants to very large systems with $100 \mathrm{MW}_{\text {th }}$ capacity. At least 624 SHIP systems, totalling $608,994 \mathrm{~m}^{2}$ collector area, were in operation at the end of the year 2017.

2017 was a record year for SHIP installations -124 new larger systems, totalling 192,580 $\mathrm{m}^{2}$ collector area, started operating. With this, the documented world total grew in 2017 by $25 \%$ in number of installed plants and by $46 \%$ by installed collector area. The world's largest solar process heat application began operation in February 2018 at the Amal oilfield located in the south of the Sultanate of Oman. The Miraah parabolic trough plant with a total capacity of over $100 \mathrm{MW}_{\text {th }}$ delivers 660 tons of steam per day for the extraction of viscous or heavy oil as an alternative to steam generated from natural gas.

\section{Detailed market analyses for 66 countries based on 2016 data}

By the end of 2016, an installed capacity of $457 \mathrm{GW}_{\text {th }}$ corresponding to a total of 653 million square meters of collector area was in operation in the recorded 66 countries. These figures include unglazed water collectors, flat plate collectors, evacuated tube collectors and unglazed and glazed air collectors.

The vast majority of the total capacity in operation was installed in China ( $\left.324.5 \mathrm{GW}_{\text {th }}\right)$ and Europe $\left(51.8 \mathrm{GW}_{\text {th }}\right)$, which together accounted for $82.3 \%$ of the total installed capacity. The remaining installed capacity was shared between the United States and Canada (18.6 $\left.\mathrm{GW}_{\text {th }}\right)$, Asia excluding China $\left(12.1 \mathrm{GW}_{\text {th }}\right)$, Latin America $\left(12.3 \mathrm{GW}_{\text {th }}\right)$, the MENA ${ }^{1}$ countries, Israel, Jordan, Lebanon, Morocco, the Palestinian Territories and Tunisia $\left(6.8 \mathrm{GW}_{\text {th }}\right)$, Australia and New Zealand $\left(6.5 \mathrm{GW}_{\mathrm{th}}\right)$, and Sub-Sahara African countries Botswana, Burkina Faso, Ghana, Lesotho, Mauritius, Mozambique, Namibia, Senegal, South Africa and Zimbabwe (1.5 GW $\mathrm{th}_{\mathrm{th}}$ ). The market volume of "all other countries" is estimated to amount for $5 \%$ of the total installations $\left(22.8 \mathrm{GW}_{\mathrm{th}}\right)$.

With a global share of $71.6 \%$, evacuated tube collectors were the predominant solar thermal collector technology followed by flat plate collectors with $22.1 \%$, unglazed water collectors with $6.1 \%$ and glazed and unglazed air collectors with $0.3 \%$.

The top 10 countries - those with the highest market penetration were China, the United States, Turkey, Germany, Brazil, India, Australia, Austria, Israel and Greece. The leading countries in cumulated glazed and unglazed water collector capacityin operation in 2016 per 1,000 inhabitants were Barbados ( $515 \mathrm{~kW}_{\mathrm{th}} / 1,000$ inhabitants), Austria ( $418 \mathrm{~kW}$ th $/ 1,000$ inhabitants), Cyprus (399 kW $\mathrm{th} / 1,000$ inhabitants), Israel (397 kW th/1,000 inhabitants), Greece (292 kW th/1,000 inhabitants), the Palestinian Territories (289 $\mathrm{kW}_{\mathrm{th}} / 1,000$ inhabitants), Australia (269 kWth/1,000 inhabitants), China (236 kW th $/ 1,000$ inhabitants), Denmark (204 kW $\mathrm{th}_{\mathrm{th}} / 1,000$ inhabitants) and Turkey (186 kWth $/ 1,000$ inhabitants). 


\section{Newly installed capacity worldwide in 2016}

By the end of 2016 a capacity of $36.5 \mathrm{GW}_{\text {th }}$, corresponding to 52.2 million $\mathrm{m}^{2}$ of solar collectors, were installed worldwide. This means a decrease in new collectorinstallations of $9 \%$ compared to theyear 2015. This downward trend however is less than the $14 \%$ in the year 2014/15 and seems to continue in 2017 with recovering markets mainly driven by the growth in large-scale and solar process heat installations and the recovering market in China.

The main markets in 2016 were again China $\left(27.7 \mathrm{GW}_{\text {th }}\right.$ ) and Europe (3.2 $\mathrm{GW}_{\mathrm{th}}$ ), which together accounted for $84.5 \%$ of the overall new collector installations in 2016. The rest of the market was shared between Latin America (1.2 GW $\mathrm{Gh}_{\mathrm{th}}$ ), Asia excluding China $\left(1.0 \mathrm{GW}_{\mathrm{th}}\right)$, the United States and Canada $\left(0.7 \mathrm{GW}_{\mathrm{th}}\right)$, the MENA countries $\left(0.4 \mathrm{GW}_{\mathrm{th}}\right)$, Australia $\left(0.4 \mathrm{GW}_{\mathrm{th}}\right)$, and the Sub-Sahara African countries $\left(0.1 \mathrm{GW}_{\mathrm{th}}\right)$. The market volume of "all other countries" is estimated to amount for $5 \%$ of the new installations $\left(1.8 \mathrm{GW}_{\text {th }}\right)$.

Of the top 10 markets in 2016, positive market growth was reported from Denmark due to 31 large-scale installations and 5 extensions of existing plants in 2016 and from Mexico, where a strong committed supply chain and cost-effective residential market exists and the construction market with a wide range of applications (residential solar hot water collectors, residential and commercial swimming pools, agricultural drying systems, and an increased number of larger commercial SHIP and public building installations) is a growing sector.

With a share of $73.8 \%$ of the newly installed capacity in 2016 , evacuated tube collectors are still by far the most important solar thermal collector technology worldwide. In a global context, this breakdown is mainly driven by the dominance of the Chinese market where around $86 \%$ of all newly installed collectors in 2016 were evacuated tube collectors. Nevertheless, it is noteable that the share of evacuated tube collectors decreased from about $82 \%$ in 2011 to $73.8 \%$ in 2016 , and in the same time frame flat plate collectors increased the share from $14.7 \%$ to $22.1 \%$.

In Europe, the situation is almost the opposite compared to China with $74.9 \%$ of all solar thermal systems installed in 2016 being flat plate collectors. In the medium-term perspective, the share of flat plate collectors decreased in Europe from $81.5 \%$ in 2011 to $74.9 \%$ in 2016. Driven mainly by the markets in Turkey, Poland, Switzerland and Germany the evacuated tube collectors did increase their share in Europe between 2011 and 2016 from $15.6 \%$ to $23.5 \%$.

In terms of newly installed solar thermal capacity per 1,000 inhabitants in 2016, Denmark took the lead followed by Israel and Cyprus in second position. China ranks fifth followed by Greece, Australia, Turkey, Austria and the Palestinian Territories.

\section{Distribution of systems by system type and application}

The thermal use of the sun's energy varies greatly from region to region and can be roughly distinguished by the type of solar thermal collector used, the type of system operation (pumped solar thermal systems, thermosiphon systems) and the main type of application (swimming pool heating, domestic hot water preparation, space heating, others such as heating of industrial processes, solar district heating and solar thermal cooling).

Worldwide, more than three quarters of all solar thermal systems installed are thermosiphon systems and the restare pumped solar heating systems. Similar to the distribution by type of solar thermal collectorin total numbers, the Chinese marketand Asia excluding China influenced the overall figures the most. In 2016, $89 \%$ of the newly installed systems were thermosiphon systems while pumped systems only accounted for $11 \%$. 
In general, thermosiphon systems are more common in warm climates, such as in Africa, South America, southern Europe and the MENA countries. In these regions thermosiphon systems are more often equipped with flat plate collectors, while in China the typical thermosiphon system for domestic hot water preparation is equipped with evacuated tubes.

The calculated number of water-based solar thermal systems in operation was approximately 113 million by the end of 2016. The breakdown is $6 \%$ used for swimming pool heating, $63 \%$ used for domestic hot water preparation in single-family houses and $28 \%$ attached to larger domestic hot water systems for multifamily houses, hotels, hospitals, schools, etc. Around $2 \%$ of the worldwide installed capacity supplied heat for both domestic hot water and space heating (solar combi-systems). The remaining systems accounted for around $1 \%$ and delivered heat to other applications, including district heating networks, industrial processes and thermally driven solar cooling applications.

Compared to the cumulated installed capacity, the share of swimming pool heating was less for new installations ( $6 \%$ of total capacity and $3 \%$ of newly installed capacity). A similar trend can be seen for several years now for domestic hot water systems in single-family homes: $63 \%$ of total capacity in operation and $42 \%$ of new installations in 2016 make this kind of system the most common application worldwide, but it is showing a decreasing trend.

By contrast, the share of large-scale domestic hot water applications is increasing (28\% of total capacity and $50 \%$ of newly installed capacity). It can be assumed that this market segment took over some of the market shares from both swimming pool heating and domestic hot water systems in single-family homes.

The share of solar district heating and solar process heat applications is steadily increasing despite it still only representing $3 \%$ of the global market.

\section{Employment and turnover}

Based on a comprehensive literature survey and data collected from detailed country reports, the number of jobs in the fields of production, installation and maintenance of solar thermal systems is estimated to be 708,000 worldwide in $2016 .^{2}$

The worldwide turnover of the solar thermal industry in 2016 is estimated at $€ 16$ billion (US $\$ 19.2$ billion).

\section{Levelized cost of solar thermal generated heat (LCOH)}

Solar thermal markets are facing challenging times, which is partly due to increasing economic pressure from other renewable technologies. To address this, a special focus is being given to the economics of solar thermal systems in Chapter 8 of this year's report.

The economic analysis based on 2016 cost shows that there is a very broad range in system costs, and subsequently, the levelized cost of solar heat. The cost data shown below refer to end-user (customer) prices excluding VAT and subsidies. These costs are dependent on the system type (thermosyphon or pumped) and the application, such as small domestic hot water systems for singlefamily homes, large domestic hot water systems for multi-family homes, small combined hot water and space heating systems and 


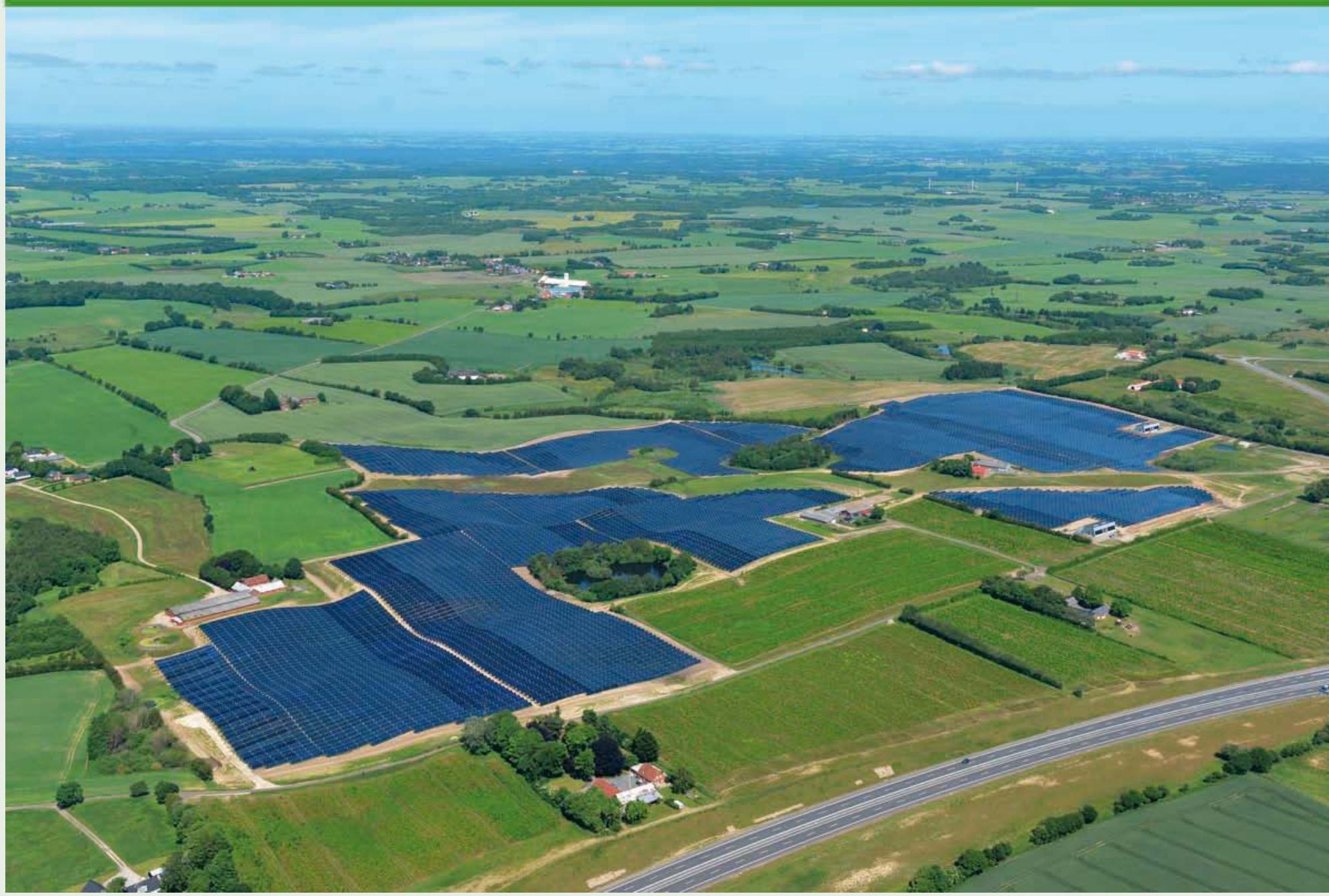

$156,694 \mathrm{~m}^{2}$ solar collector field at Silkeborg, Denmark

Photo: Arcon-SunmarkAS

swimming pool heating systems with unglazed water collectors. Furthermore, the solar fraction and the climatic conditions play an important role.

For domestic applications, the lowest $\mathrm{LCOH}$ range is between $\sim 1 €$-ct / kWh for pool heating systems (Australia, Brazil), $2-4 €$-ct / kWh for small thermosiphon domestic hot water systems (Brazil, India, Turkey) and $7-8 €$-ct/ kWh for small pumped domestic hot water systems (Australia, China).

For larger pumped systems in multi-family homes LCOH is lowest in Brazil and India ( $2-3 €$-ct / kWh).

Small combined hot water and space heating systems are cheapest in Brazil ( $3 €-c t / k W h)$.

By contrast, the highest $\mathrm{LCOH}$ range is between $\sim 2 €$-ct / kWh for pool heating systems (Canada, Israel), $7-12 €$-ct / kWh for small thermosiphon systems (Australia, China, South Africa), 12 - $20 €$-ct/ kWh for small pumped systems (Australia, Austria, Canada, Denmark, France), 8-14€-ct/ kWh for larger pumped systems in multi-family homes (Austria, Canada, Denmark, France) and $11-19 €$-ct/ kWh for small combi-systems (Austria, China, Denmark, Germany, South Africa).

For large-scale systems in Denmark $\left(>10,000 \mathrm{~m}^{2}\right)$, the average LCOH for diurnal storage is $3.6 €$-ct $/ \mathrm{kWh}$. And for even larger systems $\left(>50,000 \mathrm{~m}^{2}\right)$ with seasonal storage attached, the average $\mathrm{LCOH}$ is $4.9 €-\mathrm{ct} / \mathrm{kWh}$. 
Global solar thermal capacity of unglazed and glazed water collectors in operation grew from $62 \mathrm{GW}_{\text {th }}$ (89 million square meters) in 2000 to $472 \mathrm{GW}_{\text {th }}$ (675 million square meters) in 2017.

The corresponding annual solar thermal energy yields amounted to 51 TWh in 2000 and 388 TWh in 2017 (Figure 2).

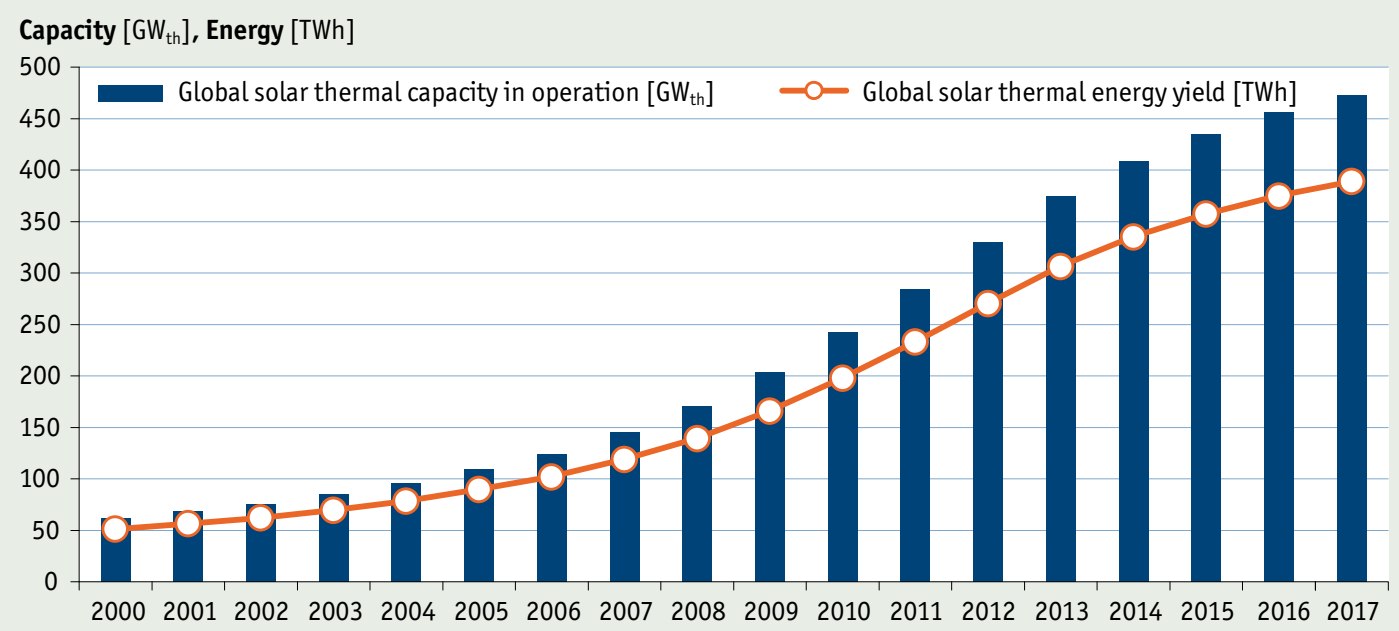

Figure 2: $\quad$ Global solar thermal capacity in operation and annual energy yields 2000 - 2017

\section{Environmental effects and contribution to climate goals}

The global solar thermal energy yields in 2017 corresponded to savings of 41.7 million tons of oiland 134.7 million tons of $\mathrm{CO}_{2}$. This shows the significant contribution of this technology to the global climate goals. 


\section{1 Solar thermal capacity in relation to the capacity of other renewable energy technologies}

Compared with other forms of renewable energy, solar heating's contribution in meeting global energy demand is, besides the traditional renewable energies like biomass and hydropower, second only to wind power (Figure 3).

The cumulated solar thermal capacity in operation by the end of 2017 was $472 \mathrm{GW}_{\mathrm{th}}{ }^{3}$, which trailed behind wind power's installed capacity of $540 \mathrm{GW}_{\mathrm{el}}$, but ahead of photovoltaics' $402 \mathrm{GW}_{\mathrm{el}}$ of installed capacity. The total capacity of concentrating solar thermal power (CSP) systems was about $5 \mathrm{GW}_{\mathrm{el}}$, which is in the range of $1 \%$ of the capacity of solar heating and cooling technologies.

In terms of energy, solar thermal systems supplied a total of 388 TWh of heat, whereas wind turbines supplied 1,430 TWh and photovoltaic systems 494 TWh of electricity.

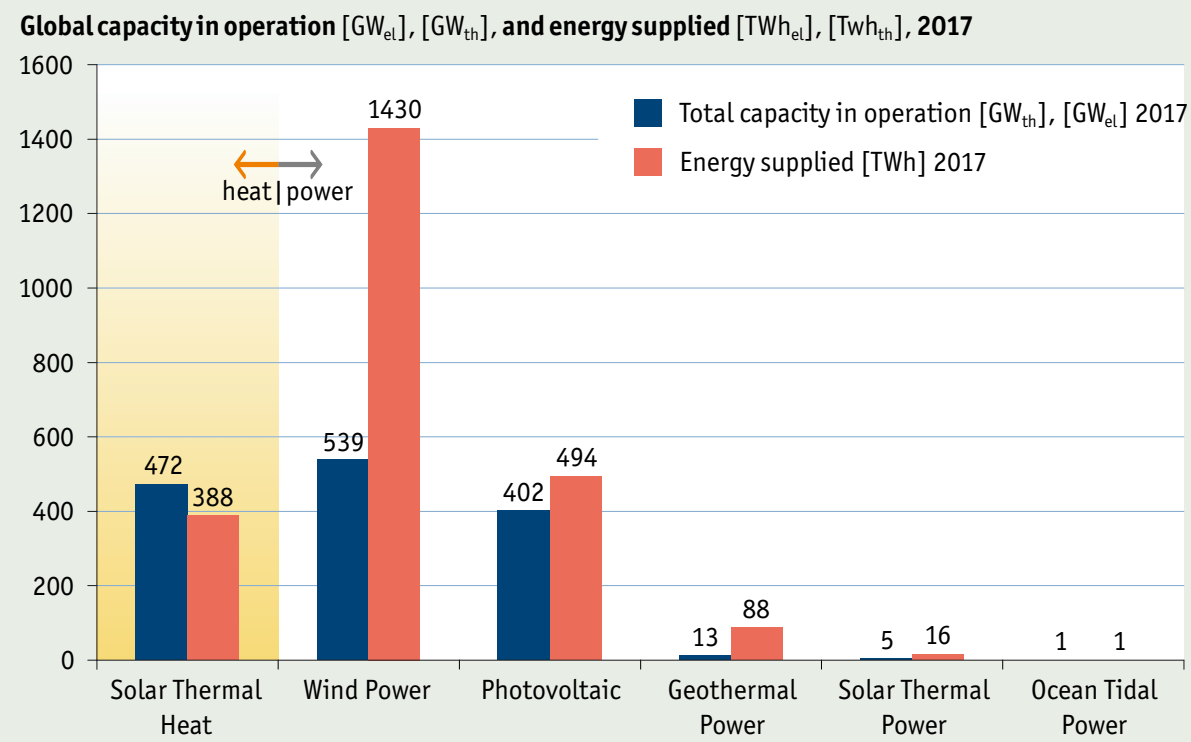

Figure 3: Global capacity in operation $\left[G W_{\mathrm{e}}\right],\left[G W_{\mathrm{th}}\right] 2017$ and annual energy yields [TWh $\left.\mathrm{e}\right],\left[T W h_{\mathrm{th}}\right]$.

(Sources: AEE INTEC, Global Wind Energy Council (GWEC), SolarPower Europe, REN21 - Global Status Report 2018)

The development of global installed capacity of solar thermal heat, wind and photovoltaics between 2010 and 2017 is shown in Figure 4. It can be highlighted that all mentioned renewable technologies show positive growth rates in terms of cumulated installed capacities.

Solar thermal was the leading renewable energy technology in terms of cumulated installed capacity in operation for many years. In 2015 wind energy caught up to a level equal to solar thermal and has been ahead of solar thermal since 2016. 
Solar thermal systems are facing challenging times. This is reflected in the continuous shrinking of the annual added collector capacity, which declined from $18 \%$ in the period $2010 / 2011$ to $4 \%$ in the period $2016 / 2017$.

Compared to theyear 2016, newinstallations declined by 4.2\% in 2017. The most dramatic development were in China wherefor the fourth year in a row the market declined. After a-17\% decline in 2014 and 2015 and a $9 \%$ decline in 2016, this trend continued 2017 with a $6 \%$ decline. For detailed country trends please refer to Chapter 5 . Besides this general trend in China it is remarkable that 2017 saw an increase of $8 \%$ in newly installed flat plate capacity in China, whereas vacuum tube capacity declined by $8 \%$. Positive market growth were recorded in India (26\%), Mexico (7\%), and in Turkey ( $4 \%$ ).

Megawatt-scale solar supported district heating systems and solar heating and cooling applications in the commercial and industrial sector have gained increasing interestall over the world in recentyears, and several ambitious projects have been successfully implemented.

Although the share of these types of systems is increasing steadily, it still only represents about $3 \%$ of the overall global installed capacity and only a few countries have installations up to now.

Small-scale solar water heating systems for detached single-family houses and apartment buildings represent approximately $90 \%$ of the worldwide annual installations, therefore a declining interest in these systems would have a significant impact, particularly in the large markets of China and Europe. These two markets are the traditional mass markets for small-scale solar water heating and to a certain extent for solar space heating systems for detached single-family houses and apartment buildings and both are under market pressure from heat pumps and photovoltaic systems.

\section{2 \\ Large-scale systems for the supply of residential, commercial and public buildings}

In the Scandinavian countries Denmark and Sweden, as well as in Austria, Germany, Spain and Greece, large-scale solar thermal plants connected to local or district heating grids, or installed on large residential, commercial and public buildings have been in use since the early 1980s. In recent years, China and other countries have installed a number of large-scale systems. 
By the end of 2017, 296 large-scale solar thermal systems (>350 $\left.\mathrm{kW}_{\text {th }} ; 500 \mathrm{~m}^{2}\right)$ were in operation (Figure 5). The total installed collector area of these systems equaled 1,741,344 $\mathrm{m}^{2}$. The capacity of these systems (excluding concentrating solar thermal systems) was $1,140 \mathrm{MW}_{\text {th }}$.

In 2017, 15 large-scale solar thermal systems were added worldwide. Of these installations, two installations each in Austria, Denmark and Germany and one large-scale system each in Sweden, France and in the Republic of Serbia were installed. In addition, the collector area of three existing Danish plants was extended.

Outside Europe in 2017 one large-scale system for district heating was installed in Australia, one in Kyrgyzstan and four in China. The total capacity of these systems is $5.9 \mathrm{MW}_{\text {th }}\left(8,444 \mathrm{~m}^{2}\right.$, excluding one concentrating solar thermal system with $9,000 \mathrm{~m}^{2}$ in Tibet).

The nine large-scale systems added in Europe in 2017 account for about $35,000 \mathrm{~m}^{2}\left(24.5 \mathrm{MW}_{\mathrm{th}}\right.$ ) of solar collectors. Of the new collector area, $46 \%$ was installed in Denmark. .

Denmark is the European frontrunner for large-scale solar district heating system installations, but in 2017 the market dipped. After a record high in 2016, with 31 newinstallations equalling 400,000 $\mathrm{m}^{2}$ of large-scale collector fields across the country, Denmark was down to only two new installations and three extensions of existing solar district heating systems with a total capacity of 18.6 $\mathrm{MW}_{\text {th }}\left(26,536 \mathrm{~m}^{2}\right)$ in 2017.

No. of systems [-]

Collector area $\left[\mathrm{m}^{2}\right]$

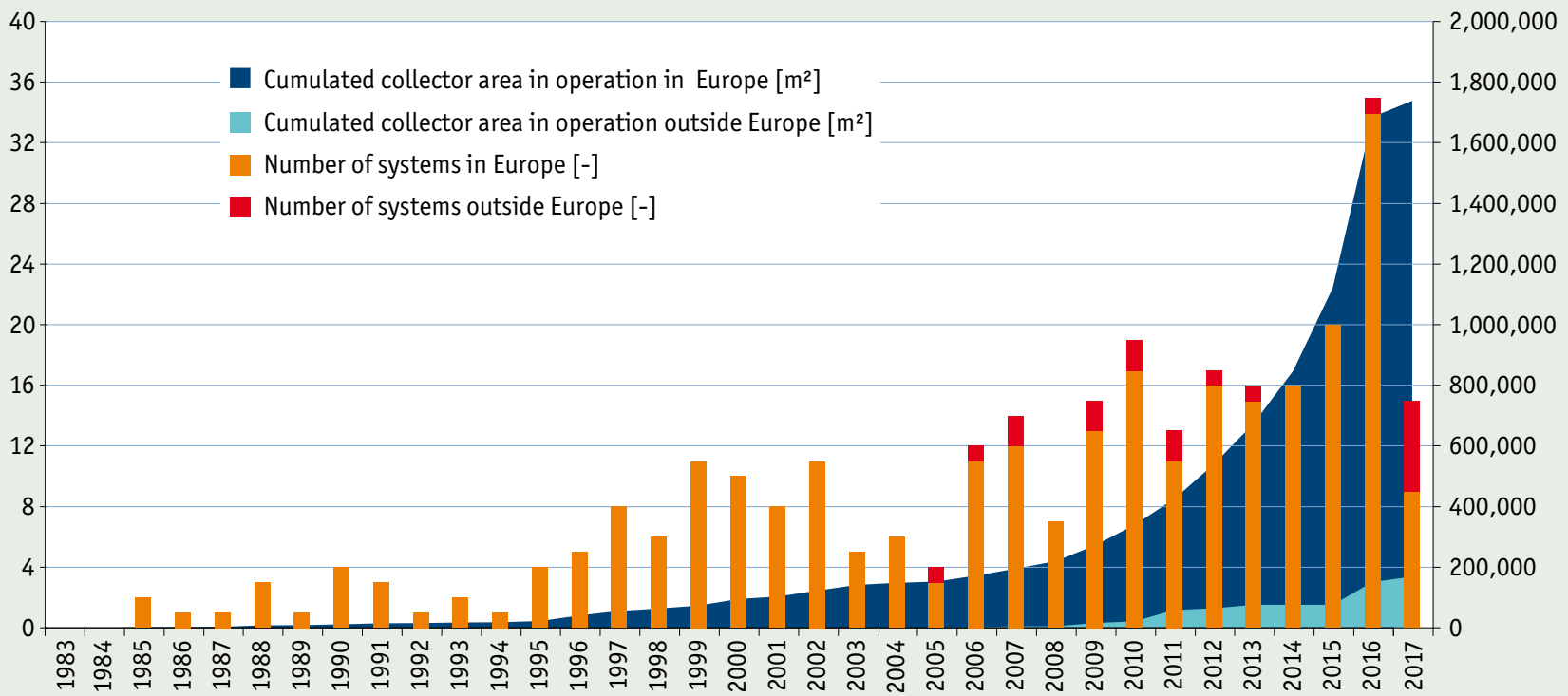

Figure 5: $\quad$ Large-scale systems for solar district heating and large residential, commercial and public buildings worldwide - annual achievements and cumulated area in operation in 2017 (Data source: Jan-Olof Dalenbäck - Chalmers University of Technology, SE and Sabine Putz - IEA SHC Task 55, Bärbel Epp solarthermalworld.org) 


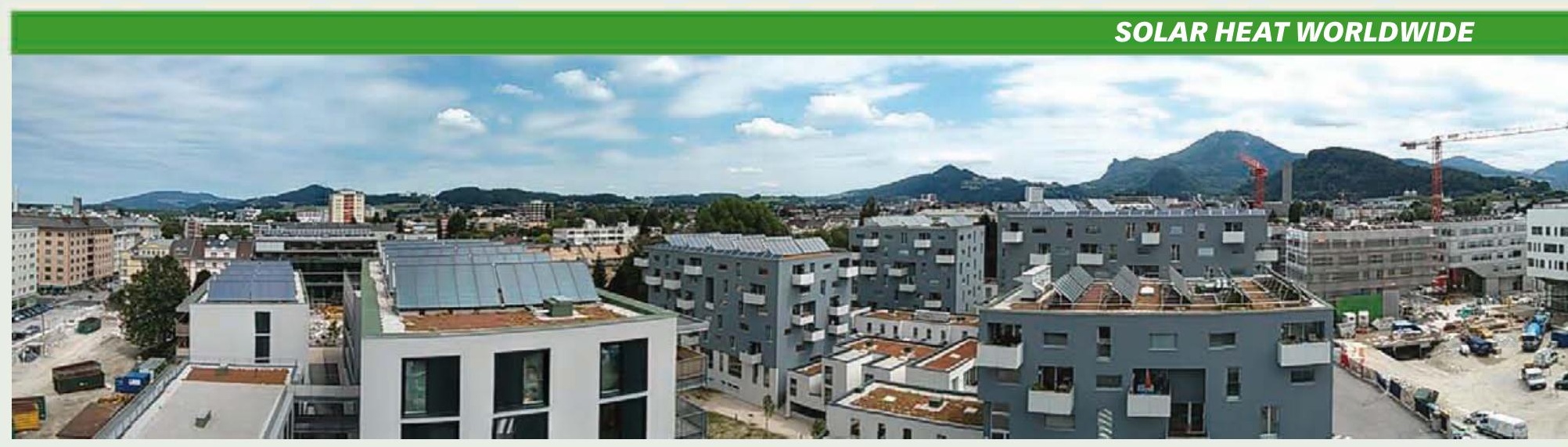

Solar thermal systems on multi-family houses in Salzburg, Austria

Photo: AEE INTEC

The biggest sub-sector of the systems described above is solar assisted district heating. And, Denmark is the leader by far not only in Europe but also worldwide, in the number of systems as well as in the installed capacity. The collector area for solar district heating in Denmark adds up to $1,327,451 \mathrm{~m}^{2}$ with an installed capacity of $910.4 \mathrm{MW}_{\text {th }}$ by end of $2017 .{ }^{4}$ The average system size of these plants calculates to be $8.2 \mathrm{MW}_{\mathrm{th}}\left(11,746 \mathrm{~m}^{2}\right)$. Most of the Danish installations are ground mounted flat plate collectorfields hydraulically connected to load-balancing storages in close distance to the district heating main distribution line. The largest plants in operation are located in Silkeborg $\left(110 \mathrm{MW}_{\text {th }}\right)$, Vojens $\left(50 \mathrm{MW}_{\text {th }} ; 69,991 \mathrm{~m}^{2}\right)$, Gram $\left(31.4 \mathrm{MW}_{\mathrm{th}} ; 44,836 \mathrm{~m}^{2}\right)$ and Dronninglund $\left(26.3 \mathrm{MW}_{\text {th }} ; 37,500 \mathrm{~m}^{2}\right)$ and are equipped with seasonal pit heat storages for solar fractions of around $50 \%$ (see also Chapter 4.2.1).

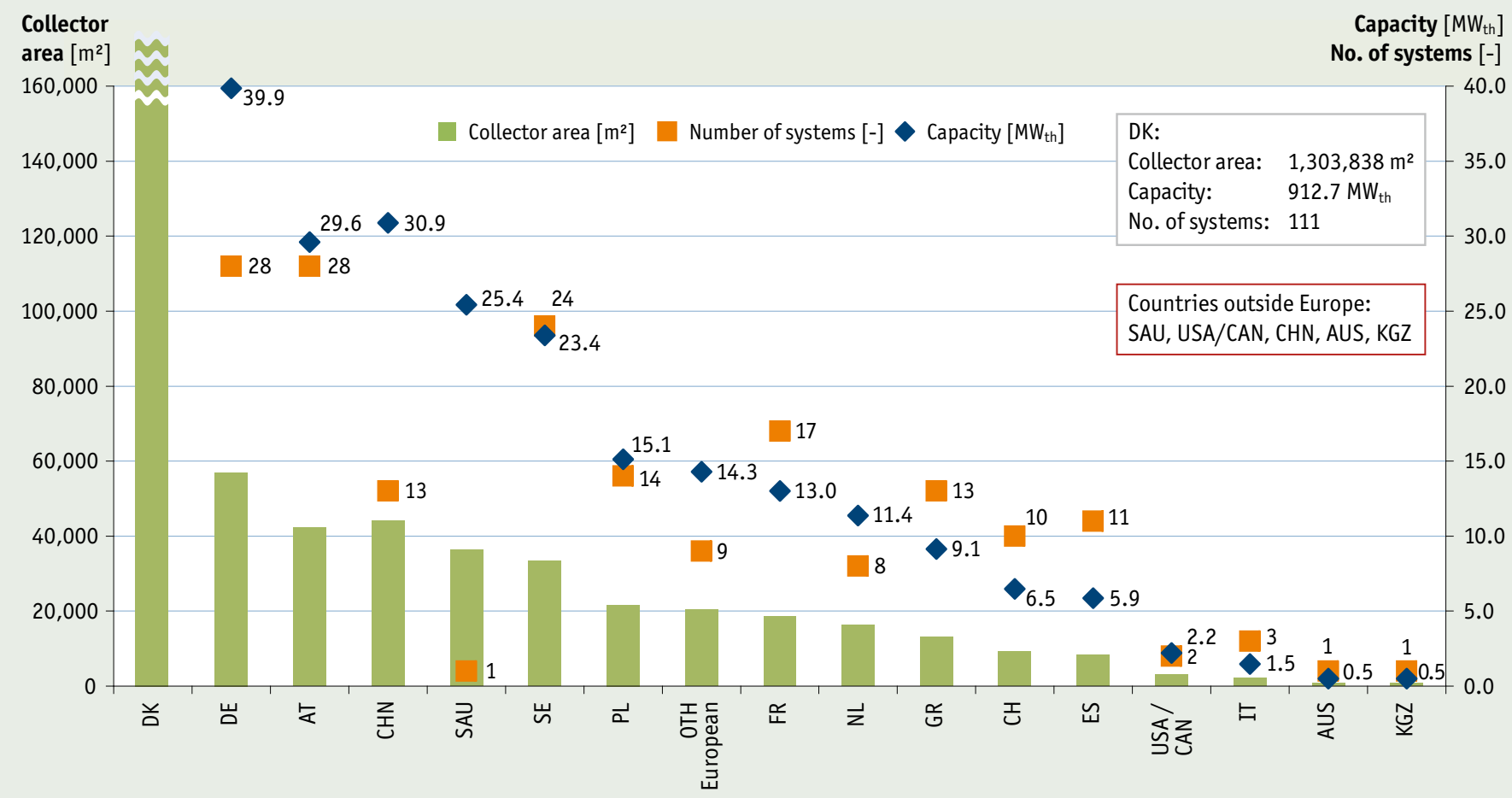

Systems with concentrating solar thermal collectors $>500 \mathrm{~m}^{2}$ excluded; worldwide this type of system added with $110,929 \mathrm{~m}^{2}$ to large-scale systems for solar district heating and large residential, commercialand public buildings.

Figure 6: $\quad$ Large-scale systems for solar district heating and residential buildings - capacities and collector area installed and number of systems in 2017 (Data source: Jan-Olof Dalenbäck - Chalmers University of Technology, SE, Sabine Putz - IEA SHC Task 55, Bärbel Epp, solarthermalworld.org)

4 For the calculation of the installed capacity of solar district heating in Denmark by end of 2017 the system of Brønderslev with an installed collector area of $26,929 \mathrm{~m}^{2}$ has been excluded because it is a concentrating solar thermal system. 


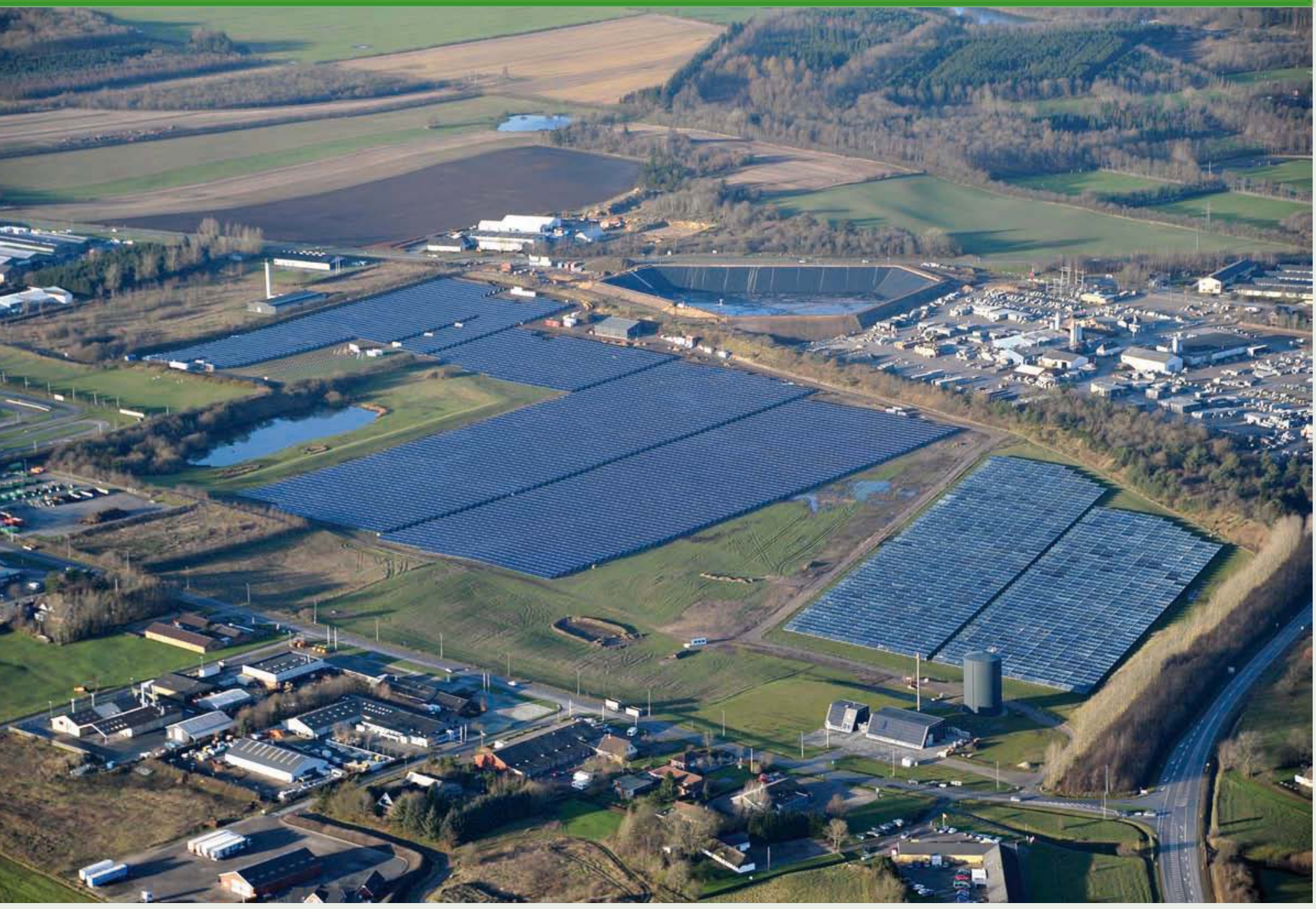

Solar district heating system in Vojens with load-balancing pit storage, Denmark.

Photo:Arcon-SunmarkA/S

Figure 6 shows solar district heating systems and large-scale systems for large residential, commercial and public buildings (excluding concentrating solar thermal systems) in Europe and worldwide. In Denmark, the share of large-scale systems for large residential, commercial and public buildings is less than $1 \%$ (a collector area of about 3,300 $\mathrm{m}^{2}$ ).

Worldwide, Denmark is a good example for a mature and commercial solar district heating market but other markets are catching up, especially China. In several other countries smaller niche markets exist, such as in Austria where 28 systems $>500 \mathrm{~m}^{2}$ are installed to feed into district heating networks, smaller micro grids in urban quarters or local biomass heating networks and to supply large residential, commercial and public buildings. Other countries to note are Germany with 28 large-scale systems (some of these with seasonal storage), Sweden (24 systems), France (17 systems), Poland (14 systems), Greece (13 systems) and Switzerland (10 systems). 


\section{Selected large-scale systems connected to district heating in different countries}

The world's largest plant for solar district heating is located in Denmark. Silkeborg has an installed capacity of $110 \mathrm{MW}_{\text {th }}\left(156,694 \mathrm{~m}^{2}\right.$ flat plate collectors) $)^{5}$. The start of operation of this plant was in December 2016.

Besides the system in Silkeborg, a substantial number of the other largest solar thermal systems are also located in Denmark and supply heat to district heating networks. The second largest system was commissioned in the city of Vojens in 2015 with a thermal capacity of $50 \mathrm{MW}_{\text {th }}\left(69,991 \mathrm{~m}^{2}\right)$ and delivers $55-60 \%$ of the thermal energy demand of 2,000 households ${ }^{6} ;$. It is connected to a huge seasonal pit heat storage with a volume of $203,000 \mathrm{~m}^{3}$.

In Riyadh, Saudi Arabia a large-scale solar district heating plantwas commissioned in July 2011. The solar thermal plant with a total capacity of $25.4 \mathrm{MW}_{\text {th }}\left(36,305 \mathrm{~m}^{2}\right)$ is connected to a heating network for the supply of space heating and domestic hot water at a university campus.

One of the large solar district heating systems in China was installed already in 2013 at the Hebei University of Economics and Business in Shijiazhuang and supplies heat for space heating and hot water for the students' apartments. Avacuum collector field of 8.1 $\mathrm{MW}_{\text {th }}\left(11,592 \mathrm{~m}^{2}\right)$ is connected to $20,000 \mathrm{~m}^{3}$ heat storage. The overall storage comprises of 228 steel tanks that are integrated into a building. Another large system in similar size, $7.9 \mathrm{MW}_{\text {th }}\left(11,310 \mathrm{~m}^{2}\right)$ was installed in 2008 in the new city in the resettlement district in Shenzhen.

As mentioned above, in 2017 four large-scale solar thermal plants for district heating were installed in China. Two of these systems are using concentrating solar collectors and are described in the following chapter.

The other two systems use flat-plate collectors. One of these systems is located in Lhasa, Tibet. It has a capacity of $2.24 \mathrm{MW}_{\text {th }}$ $\left(3,200 \mathrm{~m}^{2}\right)$ and is used for space heating of military barracks. The second system with a capacity of $2.17 \mathrm{MW}_{\mathrm{th}}\left(3,100 \mathrm{~m}^{2}\right)$ is installed in Inner Mongolia and supplies a residential area of the Hohehot Municipality ${ }^{8}$.

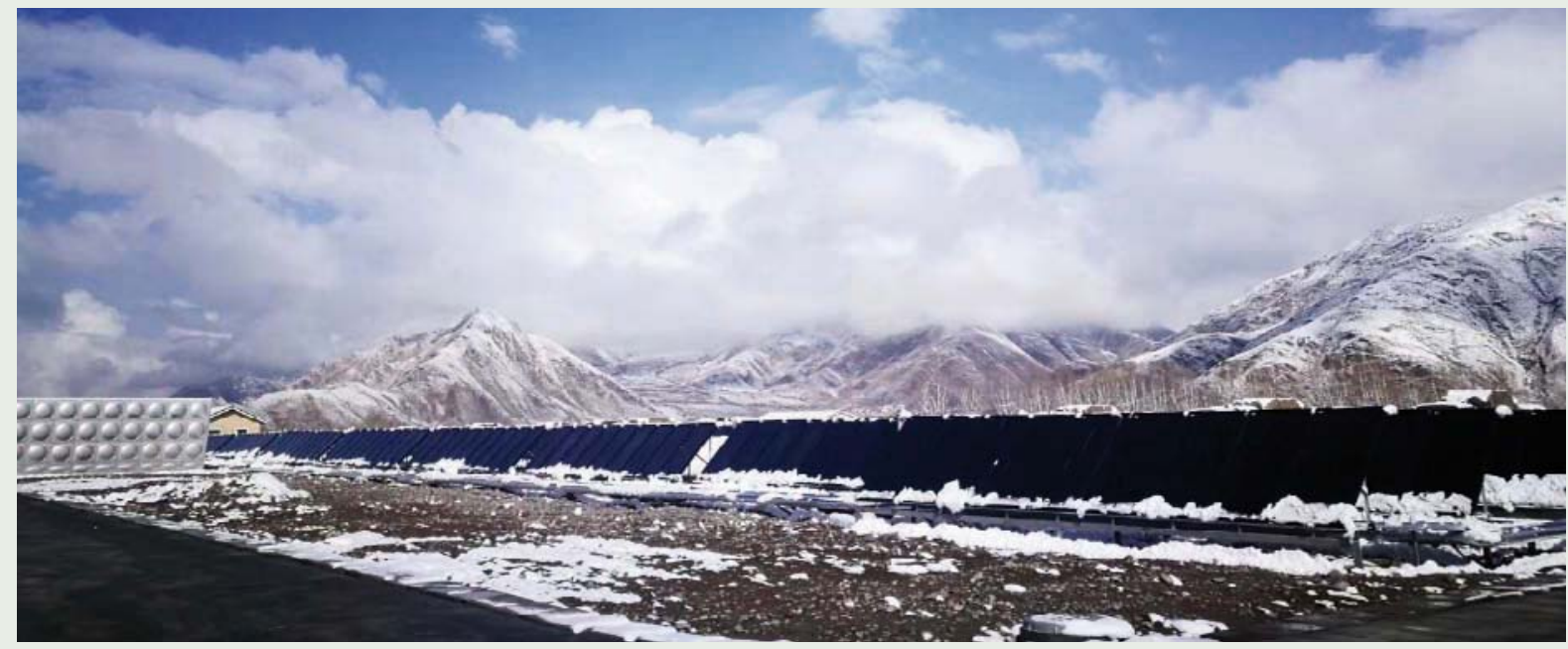

3,200 $\mathrm{m}^{2}$ solar space heating project in Lhasa, Tibet.

Photo: FIVESTARSOLAR ENERGYCO., LTD.

http://solar-district-heating.eu/ServicesTools/Plantdatabase.aspx

http://www.solarthermalworld.org/content/denmark-37-mw-field-203000-m3-storage-underway

http://www.arcon.dk/NY_Referencer.aspx

Information from Bärbel Epp - solrico 


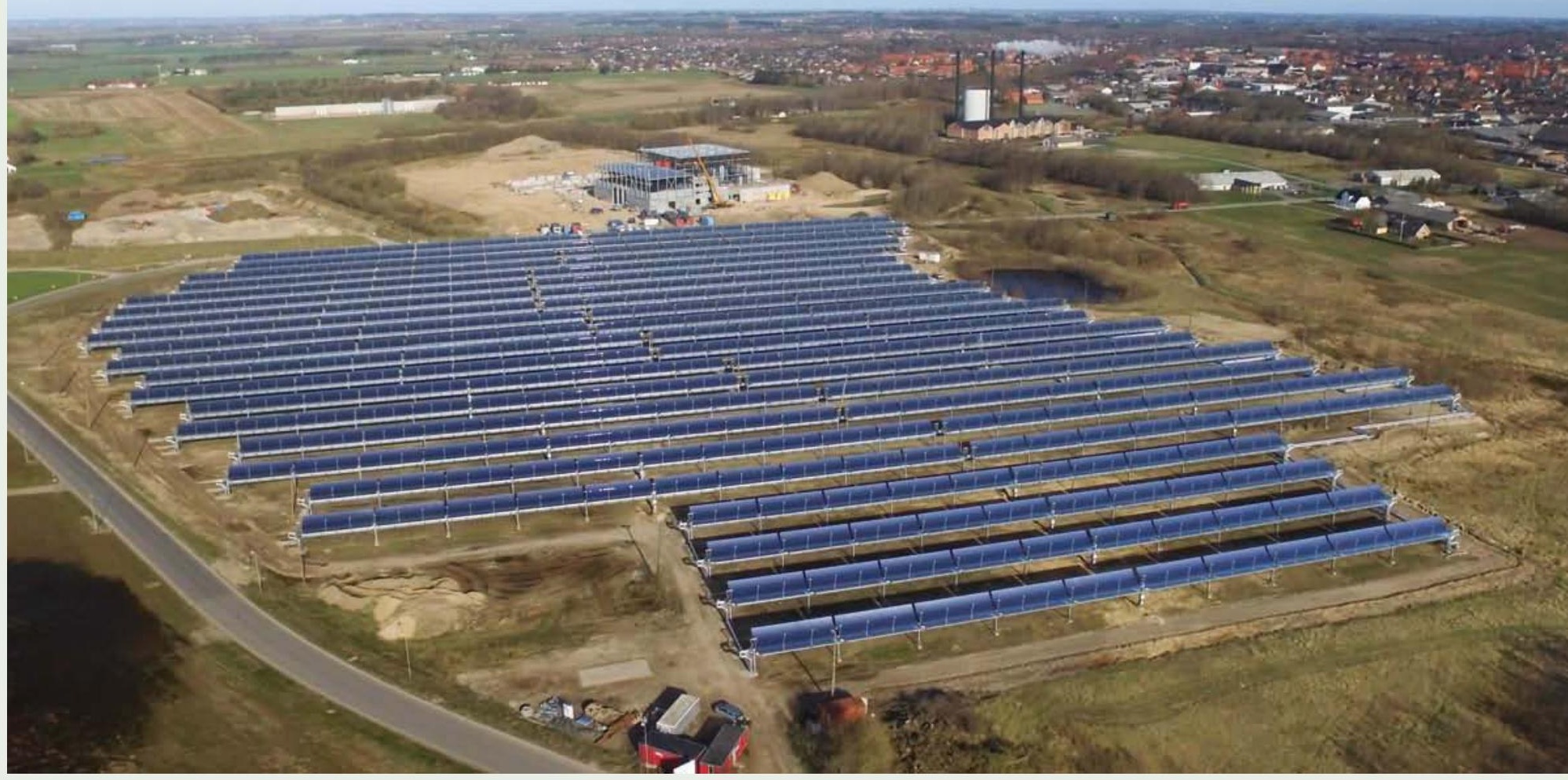

Parabolic trough collector field in Brønderslev, Denmark with an installed capacity of $16.6 \mathrm{MW}$ th supplies not only heat

Photo: Aalborg CSP

to the district heating network, but also to power production as an add-on to a biomass-fuelled ORC system.

\subsubsection{Concentrating solar collectors for district heating}

In 2016 and 2017 three concentrating solar collector fields were installed for feeding in district heating networks in Denmark and China ${ }^{9},{ }^{10},{ }^{11}$. The concentrating collector area of these three installed systems adds up to $110,929 \mathrm{~m}^{2}$.

One of these concentrating solar thermal systems has been installed in northern Denmark in the municipality of Brønderslev. Its $26,929 \mathrm{~m}^{2}$ parabolic trough collector field with an installed capacity of $16.6 \mathrm{MW}_{\text {th }}$ supplies not only heat to the district heating network, but also contributes to power production as an add-on to a biomass-fuelled organic rankine cycle (ORC) system. This combined solution is the first large-scale system in the world to demonstrate how concentrating solar collectors with an integrated energy system design can optimize efficiency ofORC even in regions with low direct solar radiation. The expected annual solaryield is $16,000 \mathrm{MWh}$ or $590 \mathrm{kWh} / \mathrm{m}^{2}$ collector area. The parabolic trough collector field has been operating since early 2017 but is going to be connected to the ORC plant in 2018.

In China two large-scale parabolic trough collector fields have been installed and connected to district heating systems. One system was installed in Inner Mongolia in 0ctober 2016 with a parabolic trough collector area of 75,000 $\mathrm{m}^{2}$, the second one in Tibet with a collector area of $9,000 \mathrm{~m}^{2}$ (in a second phase another $9,000 \mathrm{~m}^{2}$ collector area is planned to be finished in 2018). This collector field will run on thermal oil and will be connected to a molten salt storage tank.

9 http://www.solarthermalworld.org/content/denmark-concentrating-solar-collectors-district-heat-northern-europe

10 http://www.solarthermalworld.org/content/second-winter-75000-m²-sdh-heating-system-inner-mongolia

11 http://www.solarthermalworld.org/content/tibets-highly-subsidised-solar-heating-market 


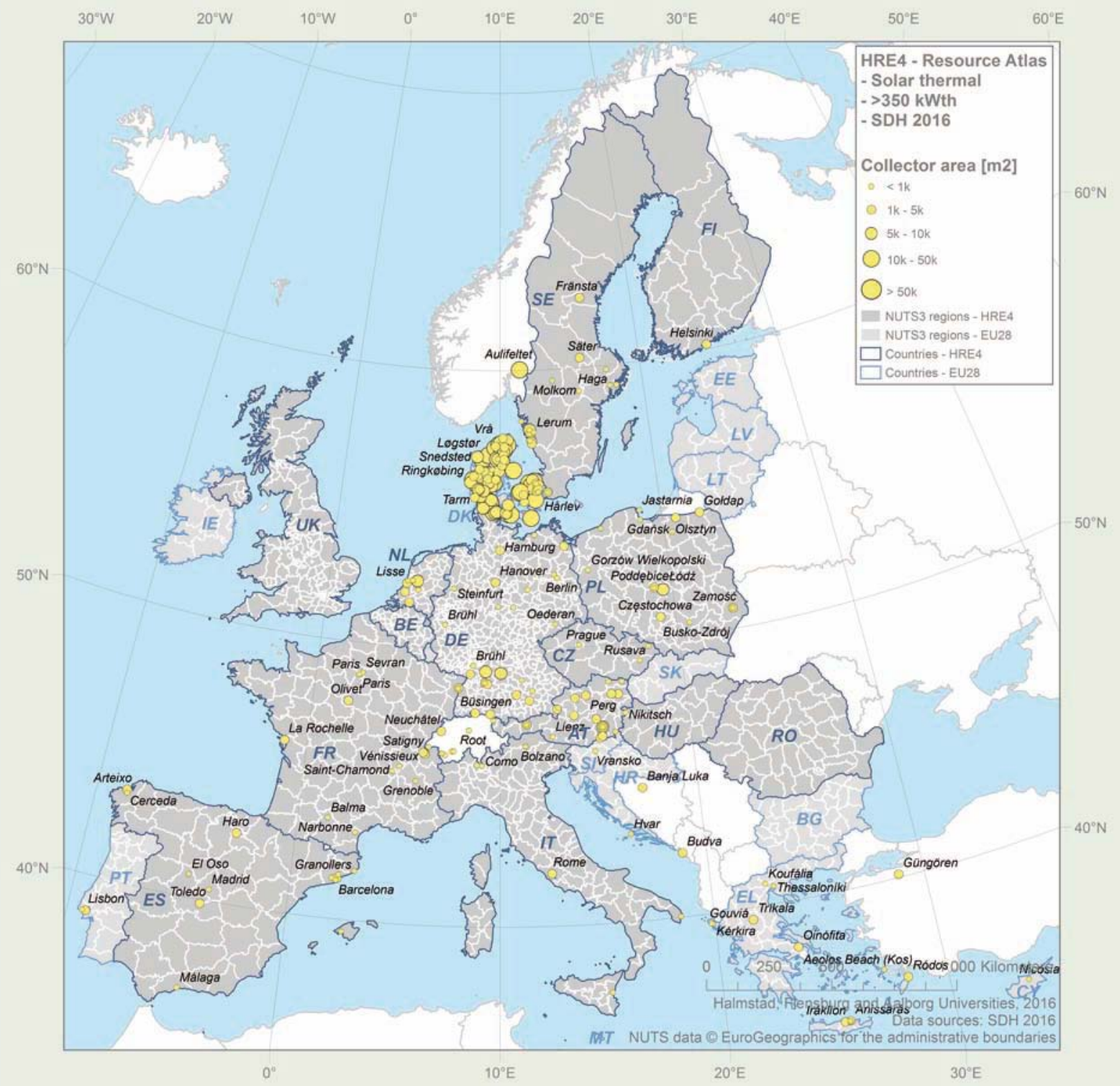

Figure 7: $\quad$ Solar district heating systems $>500 \mathrm{~m}^{2}(350 \mathrm{~kW}$ th $)$ in Europe. (Source: Heat Roadmap Europe)

\begin{tabular}{l|l} 
4.3 & Solar heat for industrial processes
\end{tabular}

A variety of industrial processes demand vastamounts of thermal energy, which makes the industrial sector a promising market for solar thermal applications. Depending on the temperature level of the needed heat, different types of solar thermal collectors are used from air collectors, flat plate and evacuated tube collectors for temperatures up to $100^{\circ} \mathrm{C}$ to concentrating solar thermal collectors, such as Scheffler dishes, Fresnel collectors and parabolic troughs for temperatures up to $400^{\circ} \mathrm{C}$.

Solar heat for industrial processes (SHIP) is a growing market. A number of promising projects have been implemented in the last couple of years ranging from small-scale demonstration plants to very large systems with $100 \mathrm{MW}_{\text {th }}$ capacity. 


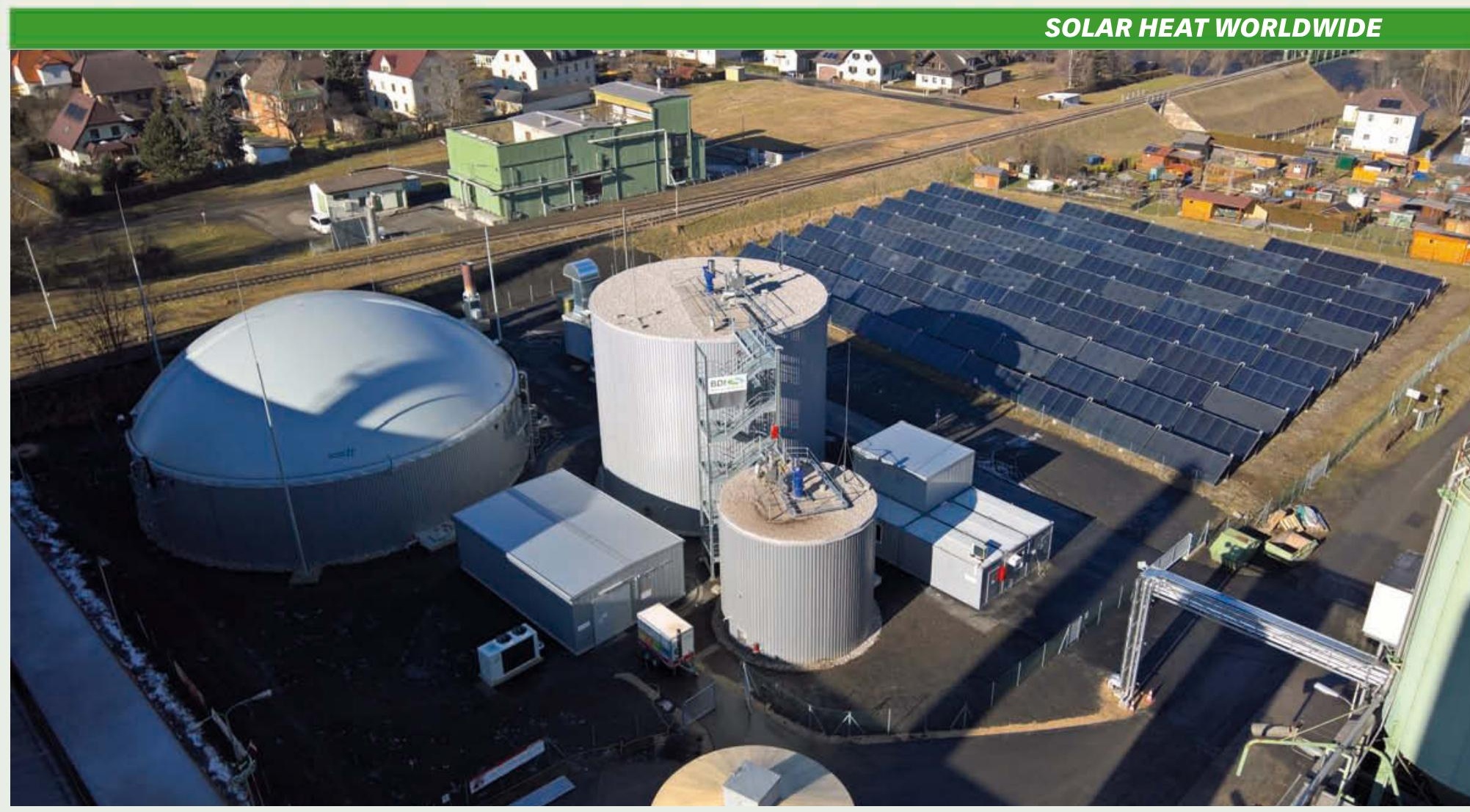

$1 M W_{\text {th }}$ solar process heat plant at the Goess Brewery in Austria.

Photo: Brauunion

Based on the data published in the AEE INTEC SHIP database ${ }^{12}$ and by SOLRIC ${ }^{13}$ and the project, Solar Payback ${ }^{14}$ at least 624 SHIP systems totalling $608,994 \mathrm{~m}^{2}$ collector area were in operation at the end of the year 2017.

2017 was a record year for SHIP installations with 124 new documented systems, totalling 192,580 $\mathrm{m}^{2}$ collector area, starting operation. With this the documented world total raised in 2017 by $25 \%$ in terms of the number of the installed plants and by $46 \%$ in terms of installed collector area. A select number of these plants are described in the following chapter.

The table below gives an overview by country of the SHIP plants installed in 2017.

\begin{tabular}{|c|c|c|c|}
\hline & $\begin{array}{l}\text { No. of systems } \\
\text { installed in } 2017\end{array}$ & $\begin{array}{l}\text { Total collector area } \\
\qquad\left[\mathrm{m}^{2}\right]\end{array}$ & $\begin{array}{l}\text { Average collector } \\
\text { system size }\left[\mathrm{m}^{2}\right]\end{array}$ \\
\hline Oman & 1 & 148,000 & 148,000 \\
\hline Mexico & 36 & 6,411 & 178 \\
\hline India & 36 & 15,313 & 425 \\
\hline China & 19 & 11,534 & 607 \\
\hline Austria & 2 & 1,785 & 893 \\
\hline France & 2 & 2,052 & 1,026 \\
\hline Afghanistan & 1 & 3,260 & 3,260 \\
\hline Jordan & 1 & 1,254 & 1,254 \\
\hline Other countries & 12 & 2,971 & 114 \\
\hline TOTAL & 124 & 192,580 & \\
\hline
\end{tabular}

Table 1: $\quad$ Solar heat for industrial processes (SHIP) plants installed in 2017. Sources: Solar Payback SHIP Supplier Survey 2017, AEE INTEC

Not included in the table's figures are the 378 small preheating units (totalling at $1.6 \mathrm{MW}_{\text {th }} ; 2,234 \mathrm{~m}^{2}$ ) that were newly installed in 2017 in the silk production center of Sidlaghatta ${ }^{15}$, in southern India used to replace wood and briquettes for preheating the traditional stoves.

12 http://ship-plants.info/

13 http://www.sunwindenergy.com/content/solar-process-heat-surprisingly-popular

14 https://www.solar-payback.com/suppliers/

15 http://www.solarthermalworld.org/content/1500-preheating-systems-indias-silk-region 


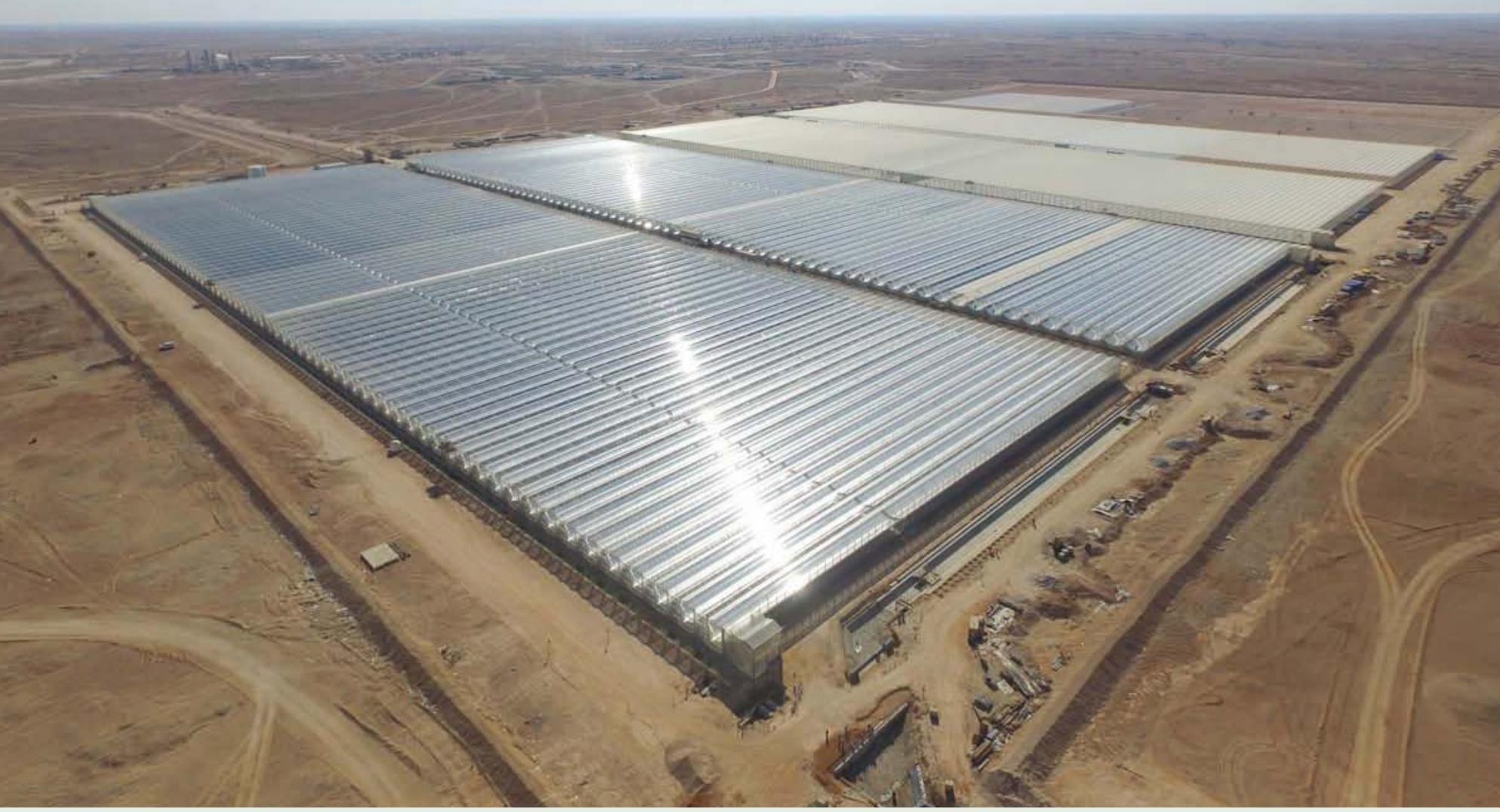

Four blocks of the Miraah solar plant with a total capacity of $100 \mathrm{MW}$ th.

Photo: Barbara Soldera, GlassPoint Solar, Inc.

\section{China}

The largest SHIP installation completed in China in 2017 was a $2.3 \mathrm{MW}_{\text {th }}\left(3,300 \mathrm{~m}^{2}\right)$ vacuum tube collector field that supplies heat to the company Heli Lithium Industry in Tibet.

Another big plant installed in 2017 uses a $1.5 \mathrm{MW}_{\text {th }}\left(2,200 \mathrm{~m}^{2}\right)$ vacuum tube collector field to supply heat to the sea vegetable processer Polyocean Algal Industry Group in the city of Quingdao, Shandong Province.

\section{Afghanistan}

A German parabolic trough collector manufacturer delivered and installed a 3,260 $\mathrm{m}^{2}$ collector field in Afghanistan at a meat production factory.

\section{Jordan}

A Fresnel collector field with a capacity of $700 \mathrm{~kW}_{\text {th }}$ (aperture area of 1,254 $\mathrm{m}^{2}$ ) for direct steam generation for solar process heating and solar thermal cooling with an absorption chiller has been installed at the Japan Tobacco International factory in Jordan. 
As Figure 9 shows, the growth for Indian systems with concentrating solar collectors (mainly Scheffler dish systems) has been steady over the years with 1 to 4 new systems every year over the last 9 years. While in Mexico, the first system with concentrating solar thermal collectors was installed in 2012 and since then have commissioned more and larger systems every year with the exception of 2016. In 2017, 11 new systems with concentrating solar thermal collectors (mainly parabolic trough) with a total area of around 4,700 $\mathrm{m}^{2}$ were installed in Mexico.

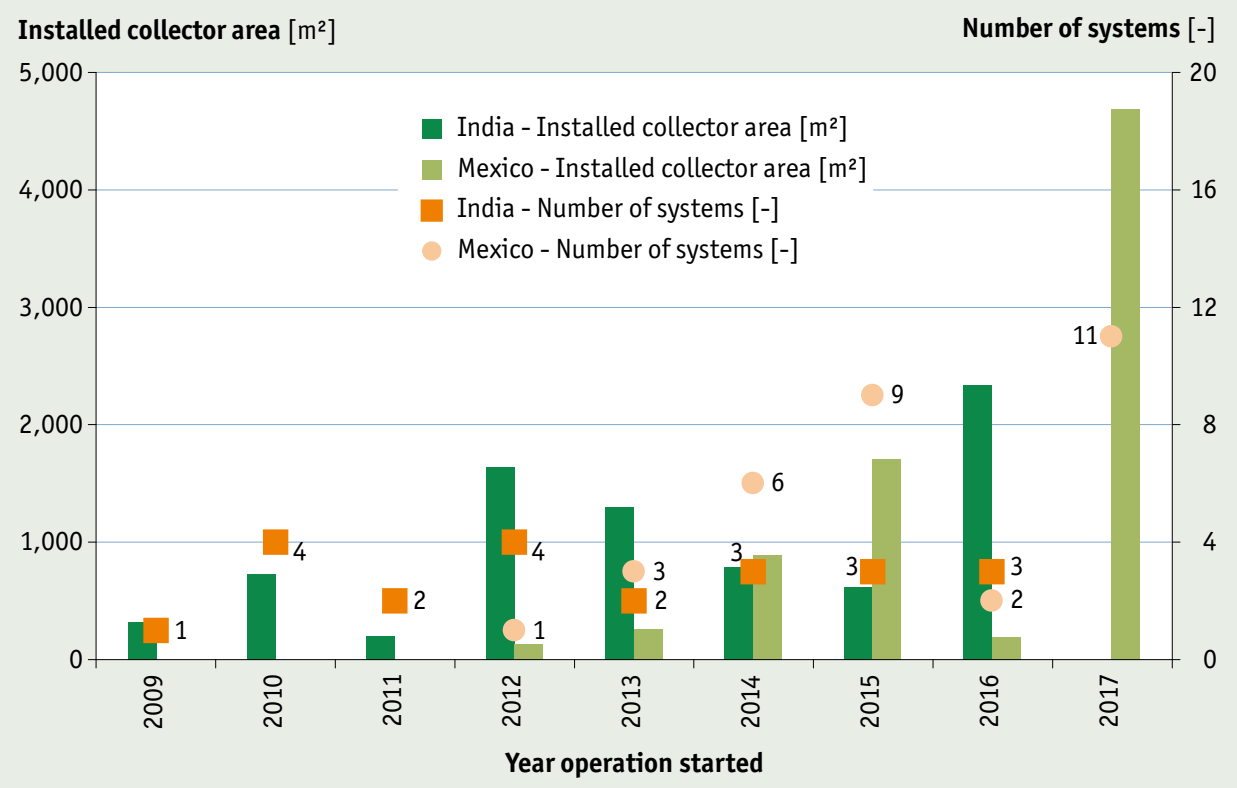

Figure 9: $\quad$ Number and gross area of installed plants with concentrating solar thermal (CST) collector systems in India and Mexico by end of March 2018. (Source: IEA SHC Task49 / IV SHIP database)

The targeted industrial sectors in Figure 10 shows that both countries have installed the majority of their systems in the food industry sectors. While Mexico has focused almost entirely on the food and beverage sectors; India also has a significant number of plants in the chemical, textile, agriculture and other industries sectors.

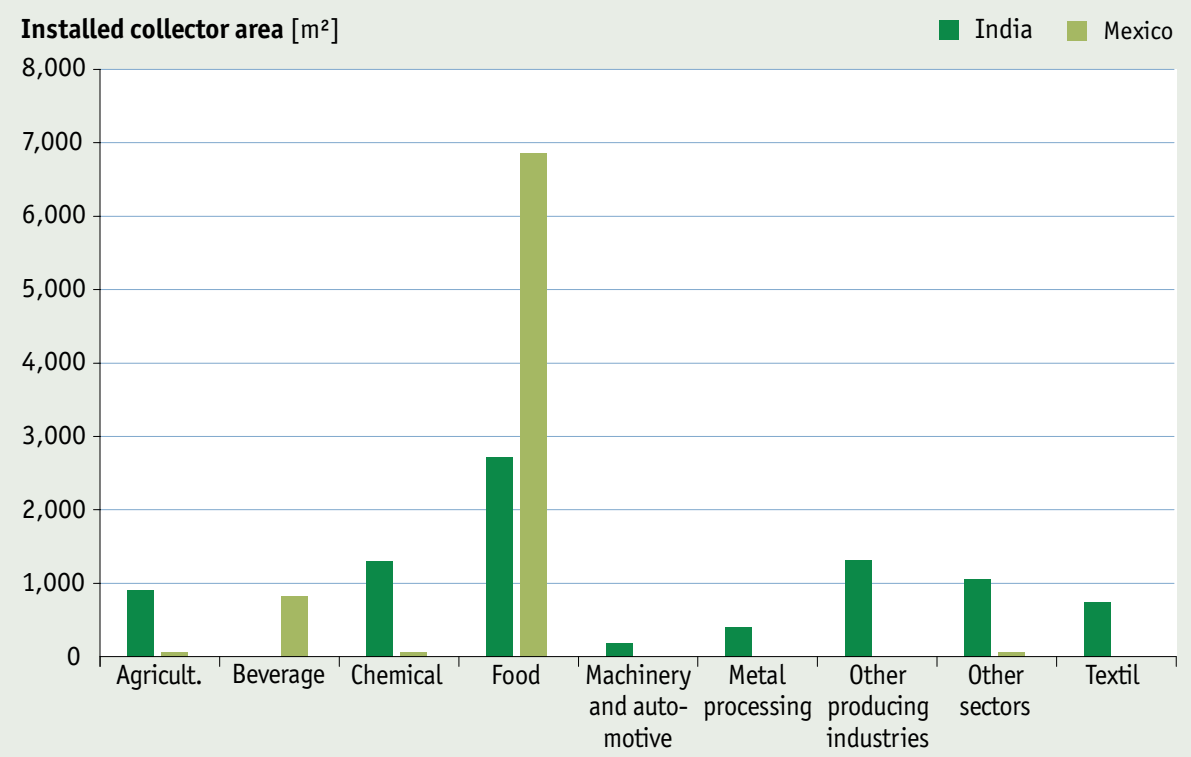

Figure 10: $\quad$ Application of concentrating solar thermal (CST) collector systems to various industrial sectors in India and Mexico by end of March 2018. (Source: IEA SHC Task49 / IV SHIP database) 
Figure 11 and Figure 12 show the number, gross area and thermal capacity of the installed plants with concentrating collectors in Mexico and India respectively. Both countries have most systems with the highest total gross area in the range of $100-999 \mathrm{~m}^{2}$. India also has one application with a gross area $>1000 \mathrm{~m}^{2}$.

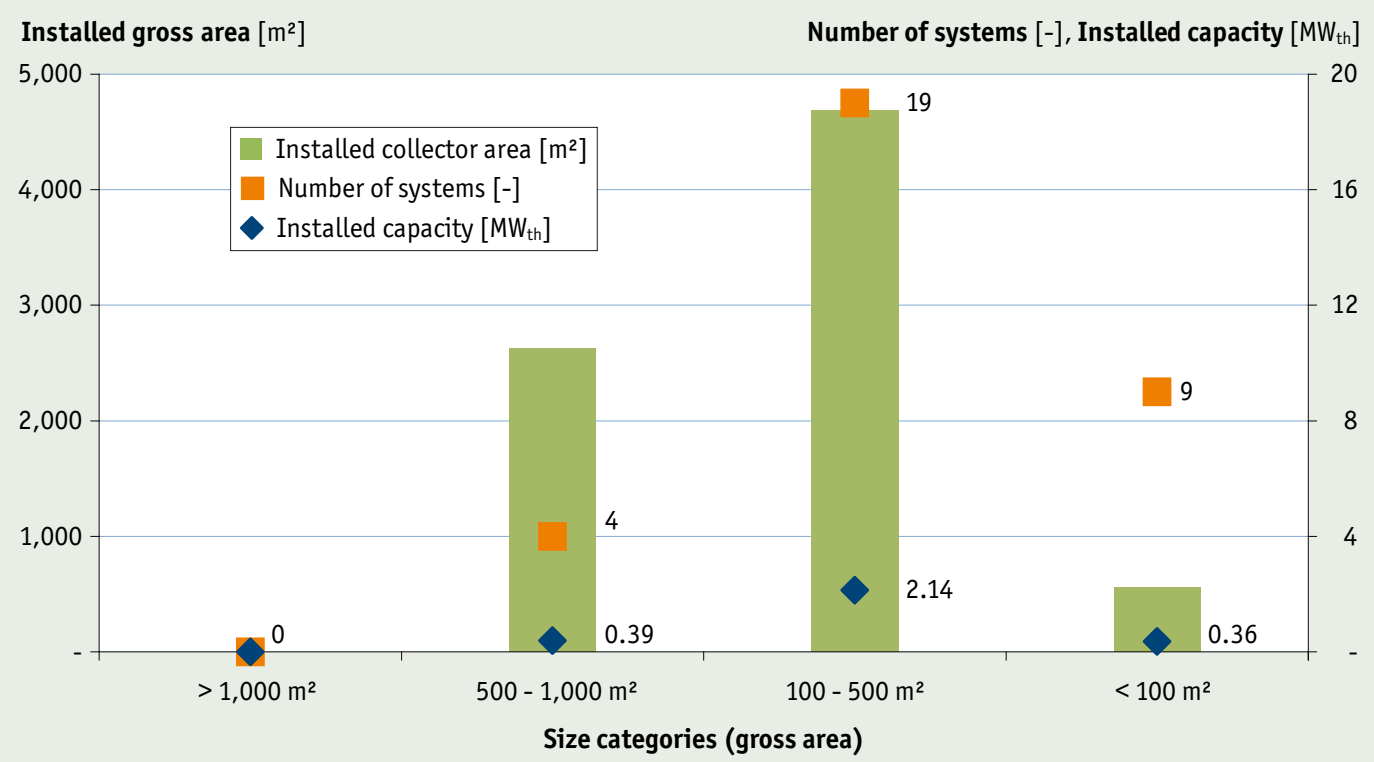

Figure 11: Number, gross area and thermal capacity of installed plants with concentrating collector types in different size categories in Mexico by end of March 2018. (Source: IEA SHC Task49 / IV SHIP database)

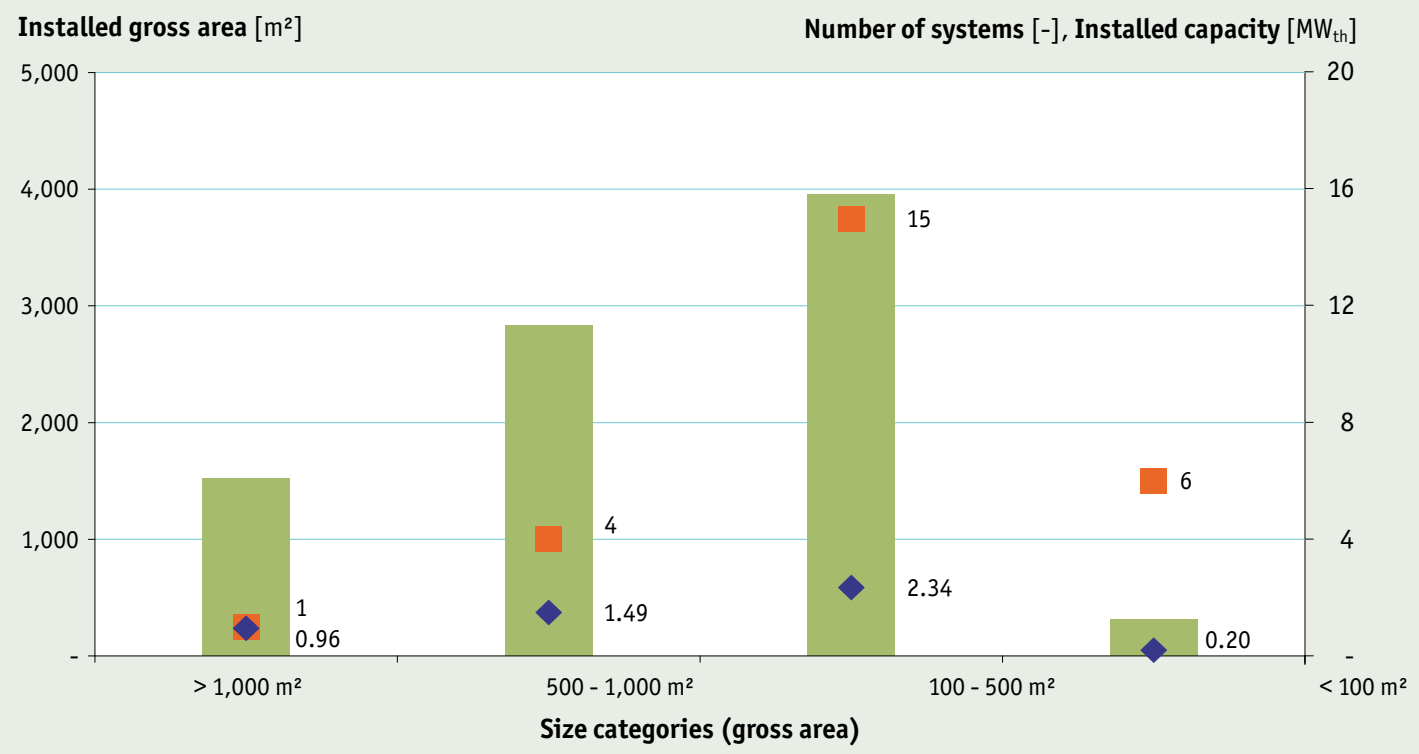

Figure 12: $\quad$ Number, gross area and thermal capacity of installed plants with concentrating collector types in different size categories in India by end of March 2018. (Source: IEA SHC Task49/IV SHIP database) 


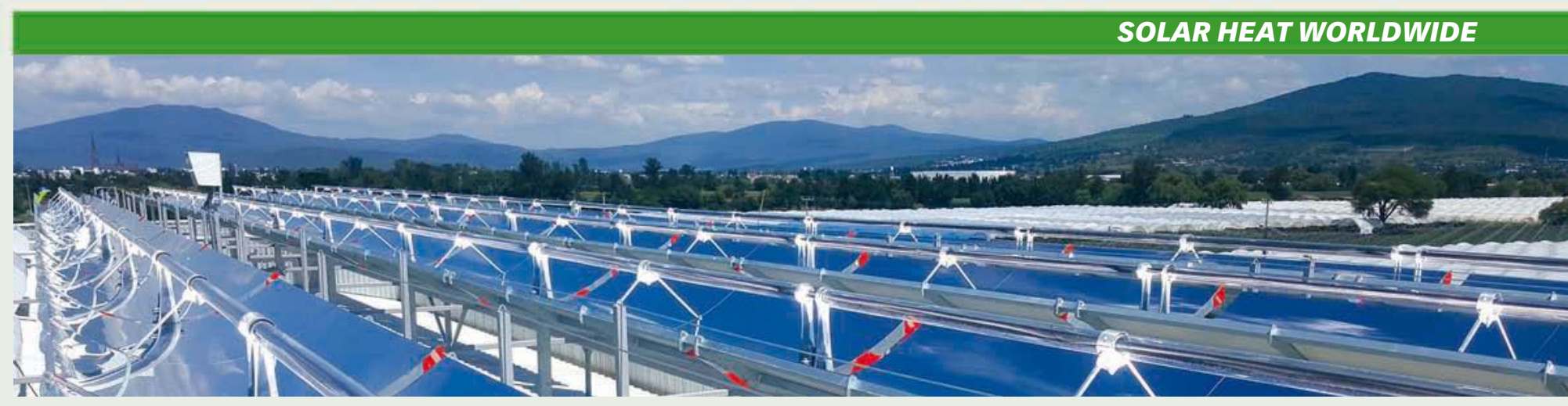

\subsubsection{Detailed analysis of 271 systems}

Photo: Inventive Power S.A.P.I. de C.V.

Of the 635 documented SHIP plants, 271 have more detailed information on the collector area and installed capacity as well as type of application and type of collector that can be found in the IEA SHC Task49 / IV SHIP database, which is an online portal operated by AEE INTEC in Austria ${ }^{17}$.

The following figures show the analysis of the systems where detailed information was available.

As described above, a $100 \mathrm{MW}_{\text {th }}$ solar process heat application was commissioned in 0man in 2017 for enhanced oil recovery. The first four blocks of this system surpass the so far largest solar process heat application in Chile, which has a thermal capacity of $27.5 \mathrm{MW}_{\text {th. }}$. Together the two systems account for $62 \%$ of the total installed thermal capacity of the 271 solar process heat plants worldwide analyzed in this chapter in detail.

Figure 13 shows the distribution of the 271 systems in terms of size. The two systems mentioned above exceed $21 \mathrm{MW}_{\text {th }}$ of thermal capacity, 26 systems have installed capacities between $0.7 \mathrm{MW}_{\text {th }}$ and $21 \mathrm{MW}_{\mathrm{th}}\left(1,000 \mathrm{~m}^{2}-30,000 \mathrm{~m}^{2}\right), 45$ systems have installed capacities between 0.35 and $0.7 \mathrm{MW}_{\text {th }}\left(500-1,000 \mathrm{~m}^{2}\right)$ and 198 systems are below $0.35 \mathrm{MW}_{\text {th }}\left(<500 \mathrm{~m}^{2}\right)$.

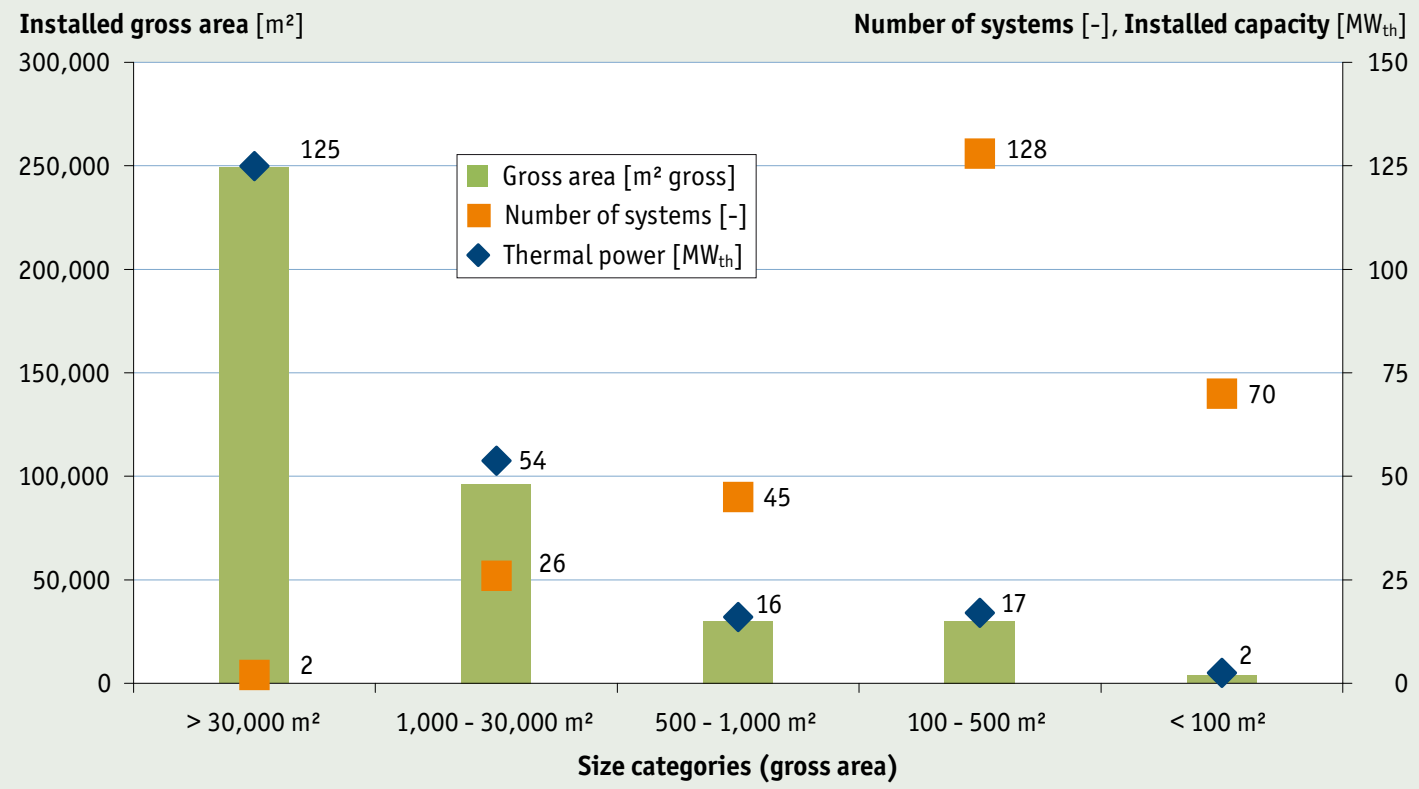

Figure 13: Global solar process heat plants in operation by capacity and collector area by end of March 2018

(Source: IEA SHC Task49 / IV SHIP database)

17 http://ship-plants.info/ 
Figure 14 shows the analyzed process heat systems in respect to the used collector technology. The majority of the systems use flat plate collectors to produce solar process heat followed by parabolic trough collectors and evacuated tube collectors. In terms of installed collector area parabolic trough collectors are ahead of flat plate collectors. Compared to theyear 2016 parabolic trough collectors took over $2^{\text {nd }}$ place in regard to the number of installed systems from evacuated tube collectors.

Installed collector area $\left[\mathrm{m}^{2}\right]$

Number of systems [-], Installed capacity [MW

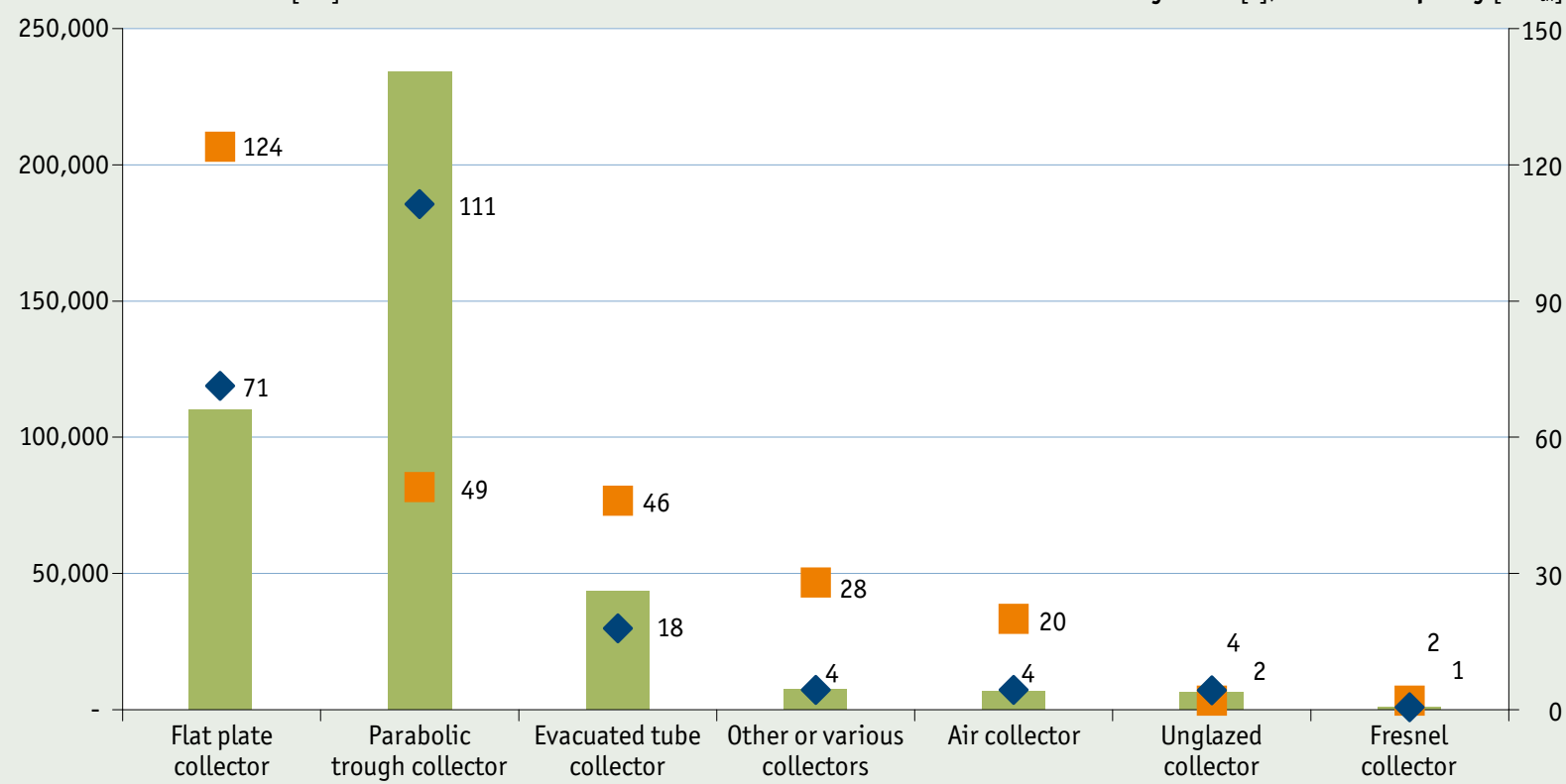

Figure 14: Global solar process heat applications in operation by type of collector by end of March 2018. (Source: IEA SHC Task49/IV SHIP database)

The following figure shows the industry sectors of the 271 systems analyzed in detail. The main sectors are mining, food and textile. While the food sector accounts for 104 systems (38\%) these systems tend to be small to medium-sized systems and thus represent in total $25.6 \mathrm{MW}_{\text {th }}(13 \%)$ of the total installed thermal capacity. On the other side, the mining sector accounts for the two largest systems (Codelco copper mine in Chile and Miraah oil field in $0 \mathrm{man}$ ) and 12 smaller systems ( $5 \%$ of total numberinstalled systems). The installed thermal capacity in the mining sector is $131 \mathrm{MW}_{\text {th }}$ and represents $65 \%$ of the total installed thermal capacity.

Installed collector area $\left[\mathrm{m}^{2}\right]$

Number of systems [-], Installed capacity $\left[\mathrm{MW}_{\mathrm{th}}\right]$

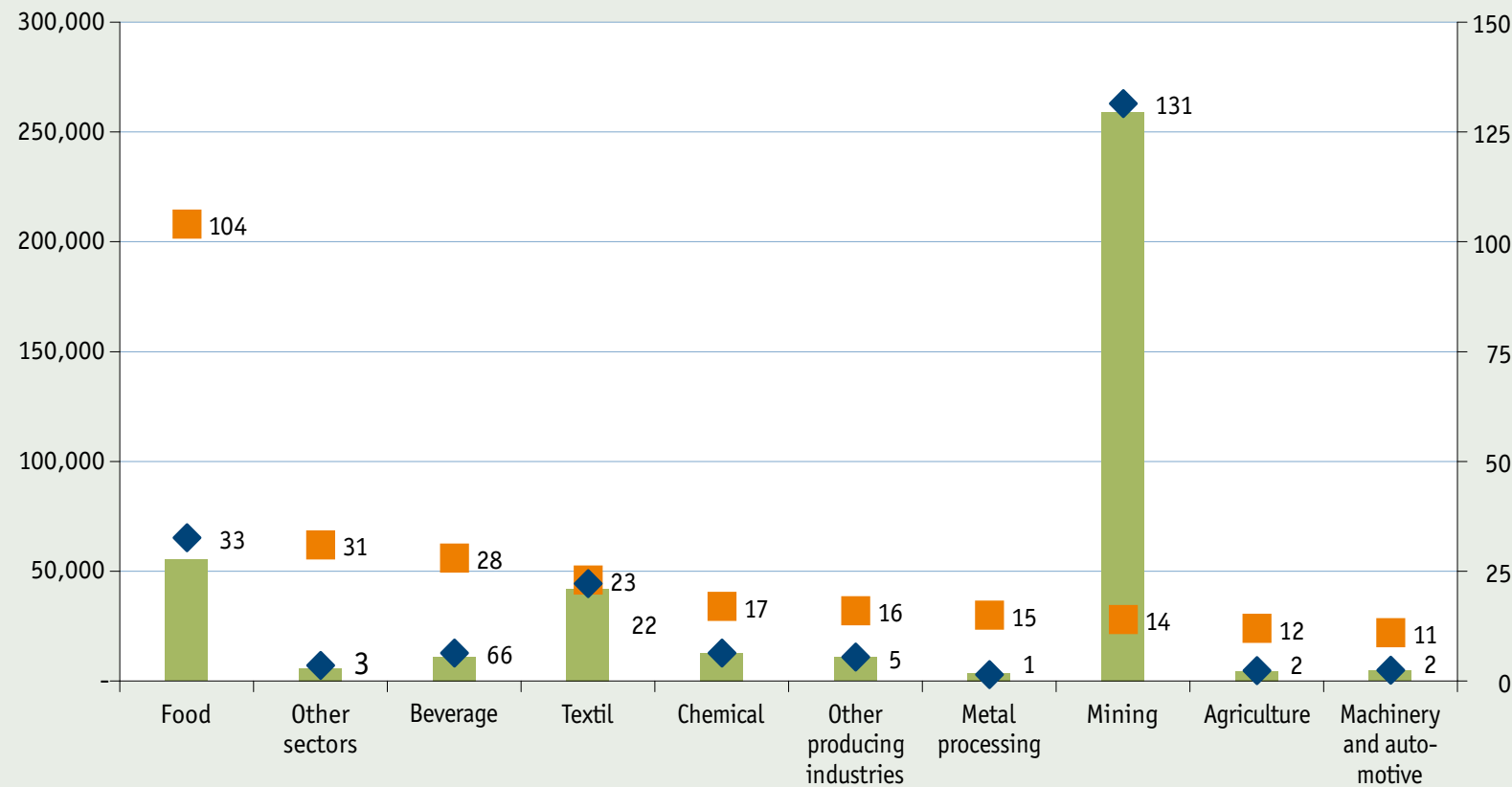

Figure 15: $\quad$ Global solar process heat installations in operation by industry sector by end of March 2018. (Source: IEA SHC Task49 / IV SHIP database) 
Figure 16 shows the global installed solar process heat systems by country. Mexico and India have the highest number of installed systems, followed by Austria, Germany, United States and Spain. In terms of solar capacity, Oman is the leader with only one system installed followed by China generated from 12 systems, and then Chile generated from two systems.

Installed gross area $\left[\mathrm{m}^{2}\right]$

Number of systems [-], Installed capacity $\left[\mathrm{MW}_{\mathrm{th}}\right]$

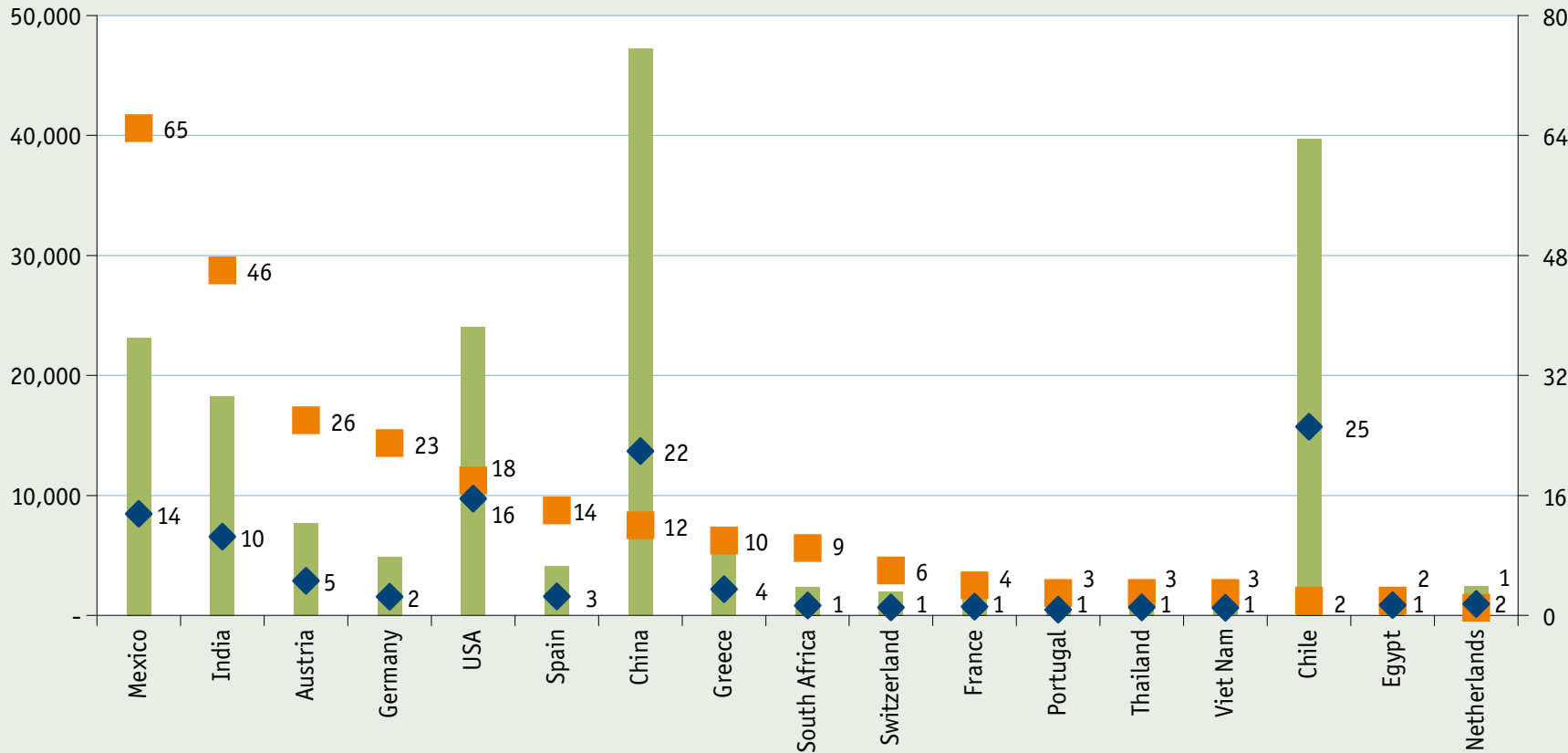

Figure 16: Global solar process heat installations in operation by country by end of March 2018. Only countries with at least $0.7 M W_{\text {th }}$

(1,000 $\mathrm{m}^{2}$ gross area) are shown (248 of 271 systems accounting for $98 \%$ of installed thermal capacity) (Source: IEA SHC Task49)

IV SHIP database)

Looking at the specific useful heat delivery in respect to the latitude, Figure 17 illustrates the range. The specific heat delivery depends on the solar radiation, ambient temperature, process integration and the process temperature level. Therefore, it has a wide range between 0.2 and about 1.5 for all countries.

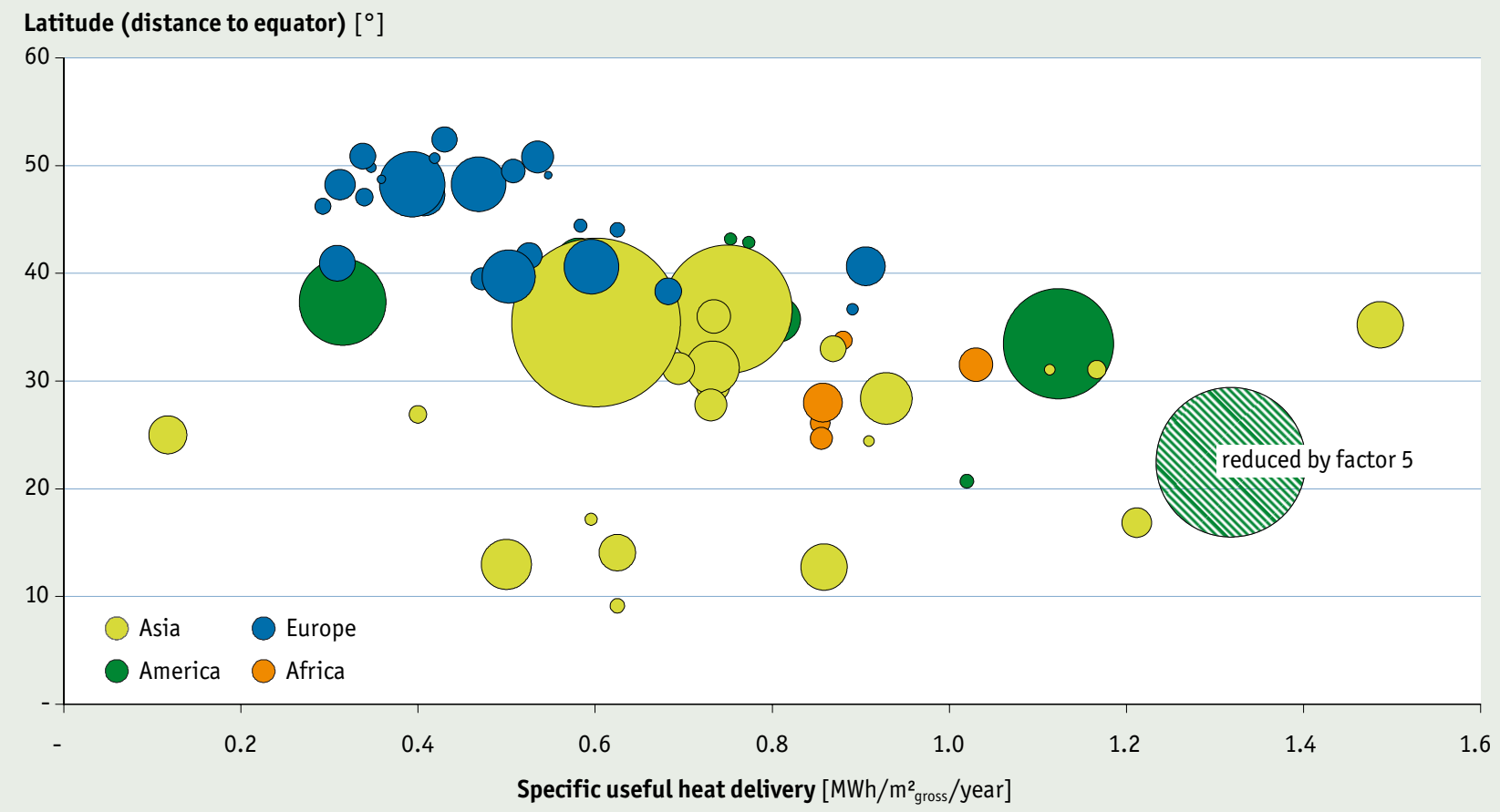

Figure 17: $\quad$ Specific useful heat delivery and latitude of installed systems by end of March 2018 (Source: IEA SHC Task49 / IV SHIP database) 


\section{4 Solar air conditioning and cooling}

\subsubsection{Small and medium size applications}

In a global market for cooling and refrigeration, which will keep growing especially in emerging countries worldwide due to their economic growth, there is a huge potential for cooling systems that use solar energy. This is related to thermal as well as PV driven solar cooling and air conditioning systems. A major argument for using solar driven systems is that they consume less conventional energy and use natural refrigerants, such as water and ammonia. In Europe, their application is also pushed by the European F-gas regulation No. 517 / 2014. Another driver of demand for solar cooling technology is its potential to reduce peak electricity demand, particularly in countries with significant cooling needs with grid constraints.

Bythe end of 2015, an estimated 1,350 solar cooling systems were installed worldwide. More recent global data are not available as data collection is difficult with more and more players entering the market, especially in Asia and the Middle East. Approximately $70 \%$ of the small and medium capacity $(<350 \mathrm{~kW})$ solar cooling systems worldwide are installed in Europe.

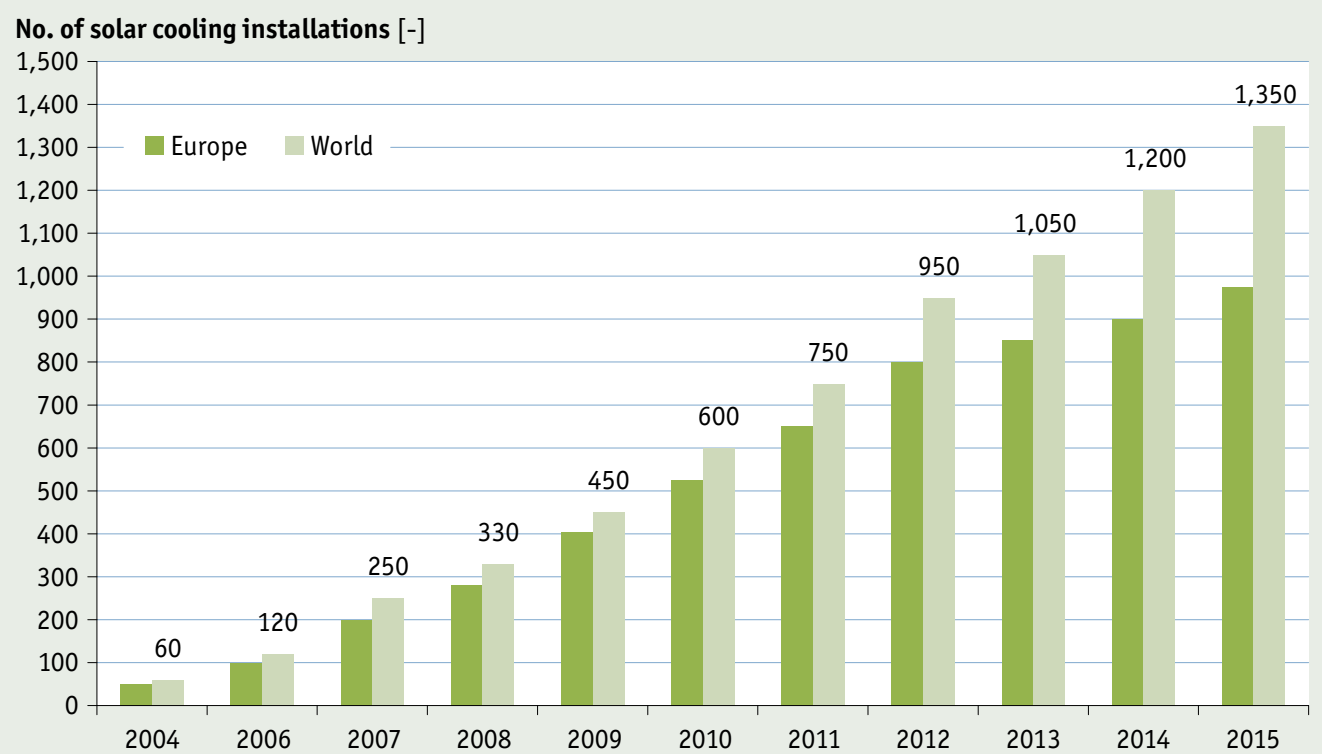

Figure 18: $\quad$ Market development 2004-2015 of small to large-scale solar air conditioning and cooling systems (Source: Solem Consulting, Tecsol)

In the segment of small and medium size applications, a new generation of solar cooling systems, either PV or thermally driven, has appeared among existing solar thermal cooling solutions. Unfortunately, a real and significant market has not yet emerged from these innovations. Nevertheless, several SME's ${ }^{18},{ }^{19},{ }^{20}$ are working on solutions to reduce the relatively high system costs, space requirements and the complexity of solar thermal-based cooling, especially for small-capacity systems.

Already, several Chinese manufacturers are including a PV option on their units as a support to the main grid supply even ifthis add on positions the overall system as an expensive air conditioner.

\footnotetext{
18 http://pvcooling.atisys.fr/

19 https://www.sunoyster.com/socool/

20 http://www.freescoo.com/en/
} 


\section{Solar cooling with a cooling capacity larger than 350 kW}

Solar cooling with thermal absorption chillers with a cooling capacity larger than 350kW / 100RT has improved significantly in performance and at the same time decreased in costs recently. Economy of scale plays an important role: Therefore, solar cooling for larger office buildings, hotels, hospitals or commercial and industrial applications have become cost competitive.

Solar thermal systems, which combine at the same timethe demand of low temperature heat (for domestic hot water) and high temperature heat (for air conditioning) are even more competitive. Those combinations are very favorable especially in moderate climates because they give a very good balance of the solar energy use over the year.

The advantage of solar energy for cooling is the match in time between solar radiation (supply) and demand. Expensive electricity in peak times can be saved. Furthermore, solar thermal energy is outstanding by the easy way of storing the solar heat and shifting it for cooling demands in the evenings and nights, and moreover keeping remaining energy for morning cooling.

The electricity needed by a system, e.g. running pumps and the cooling tower, is quite low. Depending on the climate, it may give electric COPs $\left(\mathrm{kW}_{\mathrm{th}} / \mathrm{kW}_{\mathrm{el}}\right)$ of 20 to 40 in systems with optimized variable speed drive performances. Thus, the electric demand for air conditioning in a building is cut down by more than $80 \%$ compared to conventional HVAC equipment.

The world's largest solar cooling application is located in Arizona, USA and was commissioned in May 2014. Theinstallation covers a roof-mounted solar thermal collector field with a capacity of $3.4 \mathrm{MW}_{\text {th }}\left(4,865 \mathrm{~m}^{2}\right)$ that supplies heat to a single-effect lithium bromide absorption chiller with a cooling capacity of $1.75 \mathrm{MW}$.

Several larger solar cooling systems were also installed between 2015 and 2017. These include systems for the European companies Wipotec (Germany) and for the Sheikh Zayed Desert Learning Center in Abu Dhabi²1.

In 2017, large-scale solar cooling installations were realized for IKEA Alexandra in Singapore and for Hospital Militar Escuela, Dr. Alejandro Dávila Bolaños in Managua, Nicaragua.

The solar thermal cooling system at IKEA Alexandra in Singapore has a collector area of 2,472 $\mathrm{m}^{2}$. The cooling capacity of the absorption chiller is $880 \mathrm{~kW}$ (250 tons).

The system in Managua has a total capacity of $3.1 \mathrm{MW}_{\text {th }}$ (4,450 $\mathrm{m}^{2}$ collector area). The roof mounted flat plate collector field is hydraulically connected to a $1.023 \mathrm{MW}_{\text {th }}$ absorption chiller with a cooling capacity of $1,023 \mathrm{~kW}$ and supplies hot water and cooling to Nicaragua's largest and most modern hospital with approximately 400 beds. 

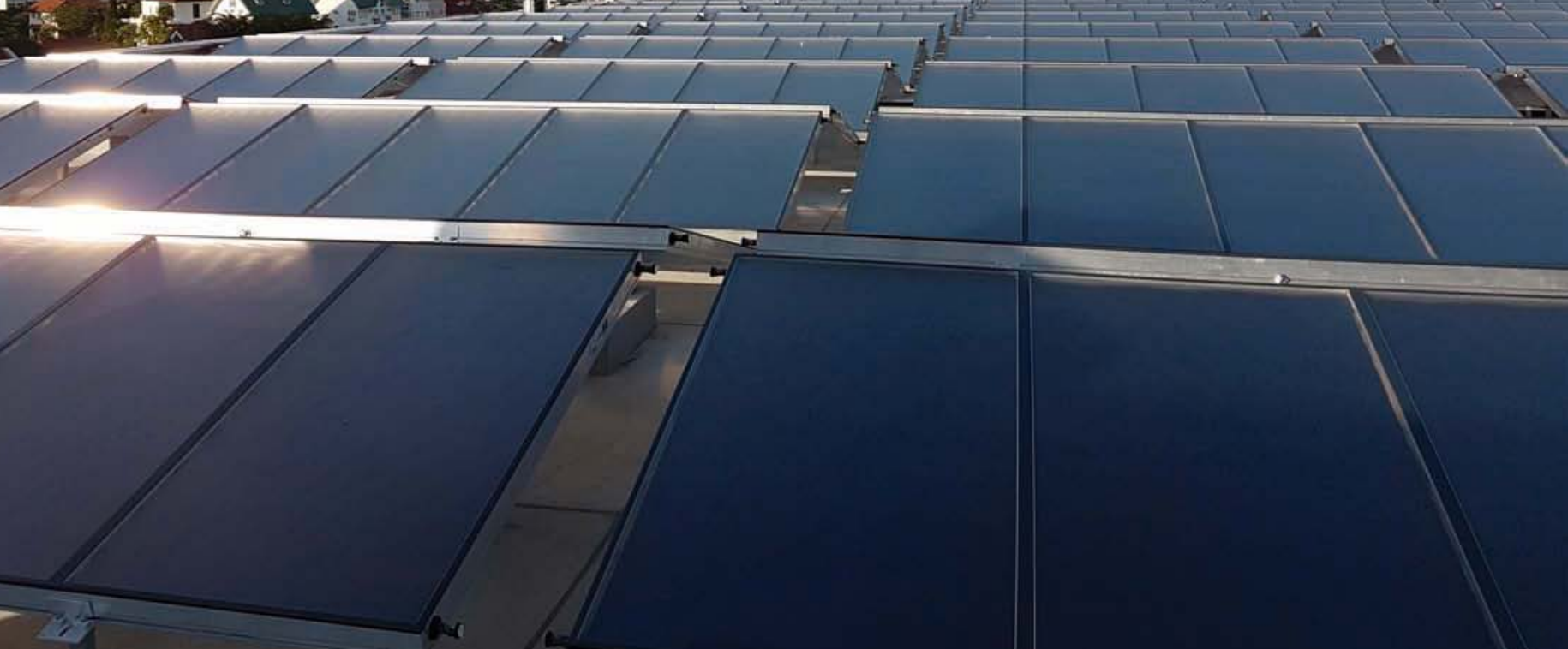

2,472 $\mathrm{m}^{2}$ solar cooling system at IKEA Singapore delivers 1,587 MWh for an $880 \mathrm{~kW}$ absorption chiller.

Photo: SOLID GmbH

\begin{tabular}{|c|c|c|c|c|c|c|}
\hline Country & Site & $\begin{array}{l}\text { Commis- } \\
\text { sioned }\end{array}$ & $\begin{array}{c}\text { Installed } \\
\text { capacity } \\
\text { [kWth] }\end{array}$ & $\begin{array}{c}\text { Collector } \\
\text { size } \\
{\left[\mathrm{m}^{2}\right]}\end{array}$ & Collector type & $\begin{array}{l}\text { Cooling } \\
\text { capacity } \\
\text { [kWcold] }\end{array}$ \\
\hline Singapore & IKEA Alexandra & 2017 & 1,730 & 2,472 & Flat plate & 880 \\
\hline Nicaragua & Hospital Militar Escuela, Dr. Alejandro Dávila Bolaños & 2017 & 3,115 & 4,450 & Flat plate & 1,023 \\
\hline India & Office, Gujarat State Electricity Corporation & 2017 & 1,102 & 1,575 & Evacuated tube & 528 \\
\hline Arizona, USA & Desert Mountain High School, Scottsdale & 2014 & 3,407 & 4,865 & Flatplate & 1,750 \\
\hline Johannesburg, South Africa & MTN Headquarter & 2014 & 272 & 484 & Fresnel & 330 \\
\hline Unitad Arab Emirates & Sheikh Zayed Desert Learning Center & 2012 & 794 & 1,134 & Flat plate & 352 \\
\hline Jamaika & Digicel, Kingston & & 687 & 982 & Flat plate & 600 \\
\hline Singapore & United World College & 2011 & 2,710 & 3,872 & Flat plate & 1,500 \\
\hline Qatar, Doha & Showcase football stadium & 2010 & 700 & 1,408 & Fresnel & n.a \\
\hline Istanbul, Turkey & Metro shopping center & 2009 & 840 & 1,200 & Evacuated tube & n.a. \\
\hline Spain, Sevilla & Sevilla University, Escuela Superior de Ingenieros & 2009 & & 352 & Fresnel & n.a. \\
\hline Lisbon, Portugal & CGD Lisbon & 2008 & 1,105 & 1,579 & Flat plate & 585 \\
\hline Rome, Italy & Metro Cash\&Carry & 2008 & 2,100 & 3,000 & Flat plate & 700 \\
\hline
\end{tabular}

Table 2: $\quad$ Large-scale solar cooling systems installed between 2007 and 2017

Sources: Blackdot Energy, Industrial Solar GmbH, Ritter XL Solar, SOLID GmbH, www.solarthermalworld.org

As can be seen in the table above, the majority of these systems are equipped with flat plate or evacuated tube collectors. By contrast, some thermal cooling machines are driven by concentrating solar thermal collectors, such as Fresnel collectors. 


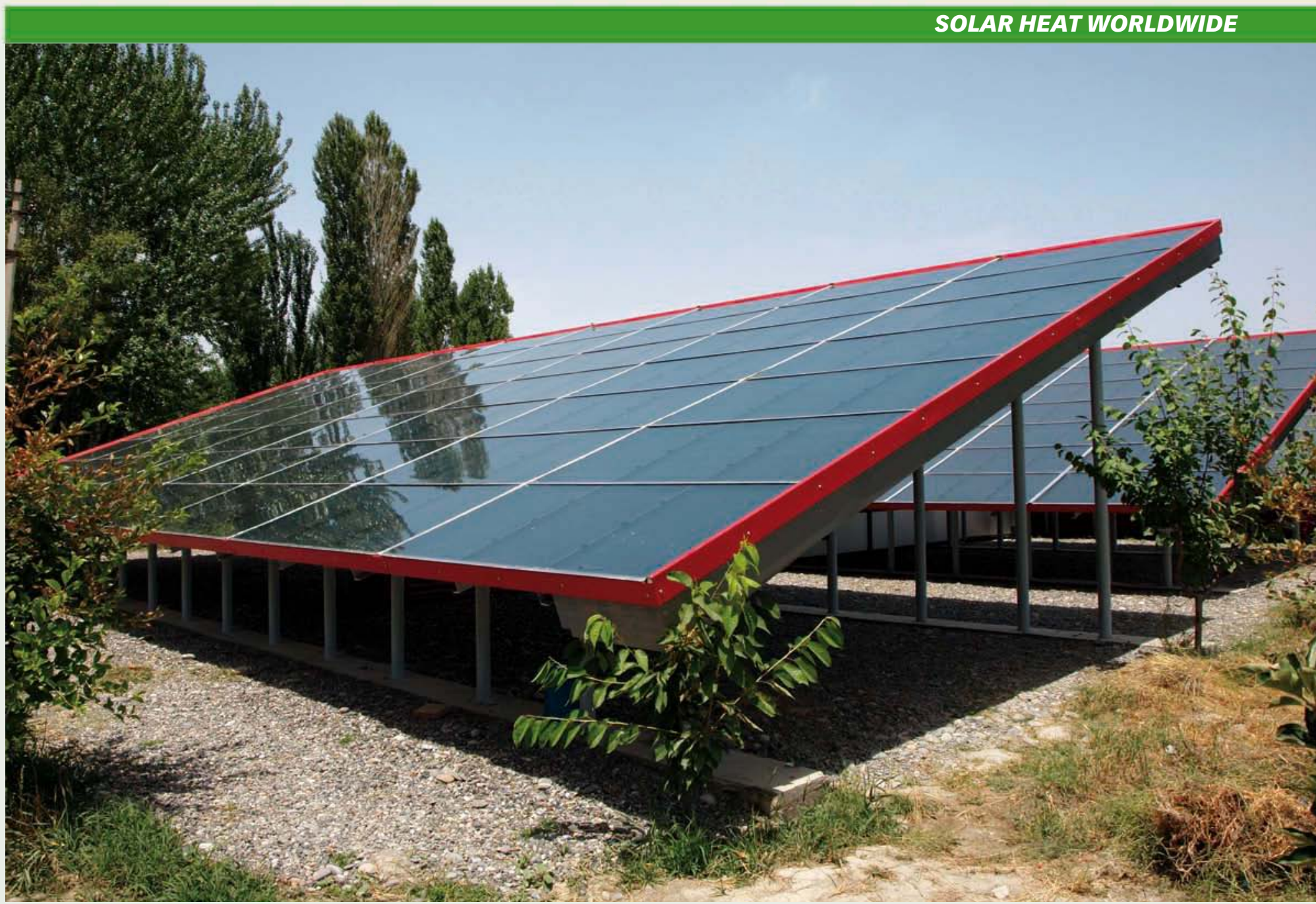

Solar air collector system in Uzbekistan.

Photo: CONA SOLARAUSTRIA

\subsection{Solar air heating systems}

Solar air heating systems have been used mainly in North America and Japan for the past 30 years by schools, municipalities, military, commercial and industrial entities as well as in in agricultural and in residential buildings. Wall mounted systems are common and take advantage of the lower winter sun angles and avoid snow accumulation as is typical of roof mounted systems. Storage of the heat is possible, but most solar air systems do not include storage to minimize costs.

Solar air heating systems in North America are typically designed to cover between 20 and $30 \%$ of the annual space heating demand of a building. The air is generally taken off the top of the collector (since hot air rises) and the heated or pre-heated fresh air is then connected to fans and ducted into the building via the ventilation system.

Solar air heaters are also common in agricultural applications primarily for drying or in some cases for wood chip drying.

By end of 2016 a total of $1.22 \mathrm{MW}_{\text {th }}\left(1,742,942 \mathrm{~m}^{2}\right)$ of glazed and unglazed air collectors wereinstalled worldwide. The annual worldwide market 2016 was at a range of $57 \mathrm{MW}_{\text {th }}\left(82,000 \mathrm{~m}^{2}\right)$.

The leading countries in air collector installations are Australia, Canada, Japan and the United States. The other markets are nearly negligible. 


\section{$5 \quad$ Detailed global market data 2016 and country figures}

The following chapters of the report show detailed solar thermal market figures for theyear 2016 and country figures for 66 countries.

Background of the presented data: The following chapters of the report show figures of the actual collector area in operation in 2016 and not the cumulated collector area installed in a country. To determinethe collector area (and respective capacity) in operation, either official country reports on the lifetime were used or, if such reports were not available, a 25-year lifetime for a system was calculated. The collector area in operation was then calculated using a linear equation. For China, the methodology of the Chinese Solar Thermal Industry Federation (CSTIF) was used. According to the CSTIF approach the operation lifetime is considered to be 10 years. For Germany a lifetime of 20 years is used.

The analysis further distinguishes between different types of solar thermal collectors, such as unglazed water collectors, glazed water collectors including flat plate collectors (FPC) and evacuated tube collectors (ETC) as well as unglazed and glazed air collectors. Concentrating collectors are not within the scope of this report.

\subsection{General market overview of the total installed capacity in operation}

By the end of 2016, an installed capacity of $457 \mathrm{GW}_{\text {th }}$ corresponding to a total of 652.9 million square meters of collector area was in operation worldwide.

The vast majority of the total capacity in operation was installed in China $\left(324.5 \mathrm{GW}_{\mathrm{th}}\right)$ and Europe $\left(51.8 \mathrm{GW}_{\mathrm{th}}\right)$, which together accounted for $82.3 \%$ of the total installed capacity. The remaining installed capacity was shared between the United States and Canada (18.6 GW $\left.\mathrm{GW}_{\text {th }}\right)$, Asia excluding China (12.1 $\left.\mathrm{GW}_{\text {th }}\right)$, Latin America $\left(12.3 \mathrm{GW}_{\text {th }}\right)$, the MENA countries Israel, Jordan, Lebanon, Morocco, the Palestinian Territories and Tunisia $\left(6.8 \mathrm{GW}_{\mathrm{th}}\right)$, Australia and New Zealand $\left(6.5 \mathrm{GW}_{\text {th }}\right)$, and Sub-Sahara African countries Botswana, Burkina Faso, Ghana, Lesotho, Mauritius, Mozambique, Namibia, Senegal, South Africa and Zimbabwe (1.5 GW th $_{\text {) }}$. The market volume of "all other countries" is estimated to amount for $5 \%$ of the total installations (22.9 $\left.\mathrm{GW}_{\text {th }}\right)$.

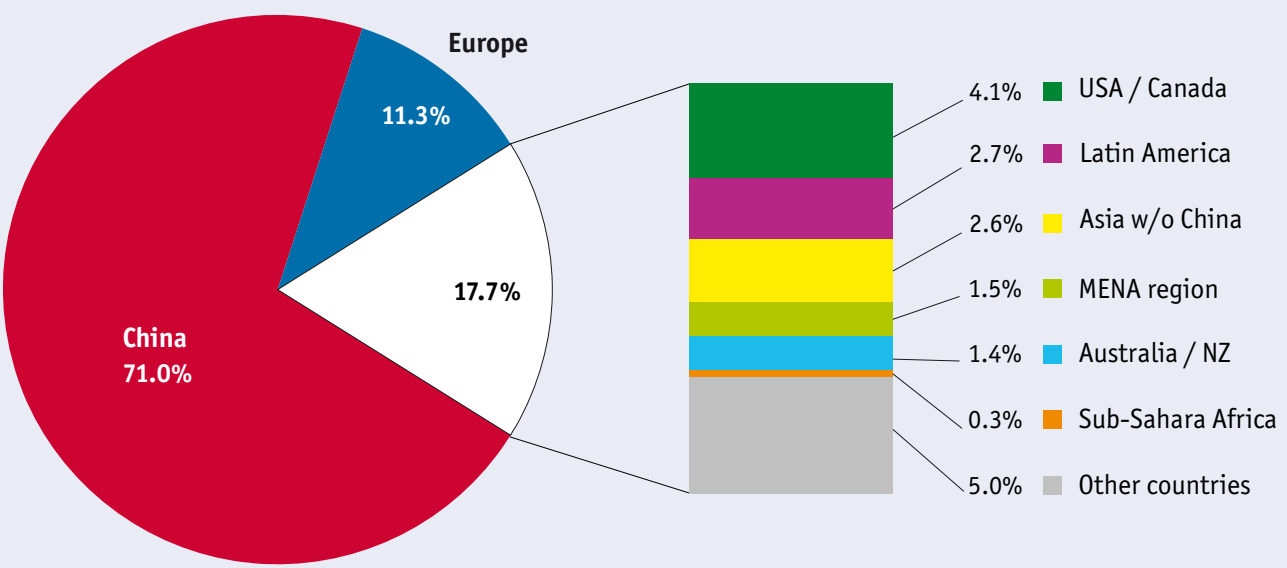

\footnotetext{
Sub-Sahara Africa:

Asiaw/o China:

Botswana, Burkina Faso, Ghana, Lesotho, Mauritius, Mozambique, Namibia, Senegal, South Africa, Zimbabwe

Latin America:

India, Japan, South Korea, Taiwan, Thailand

Europe:

Barbados, Brazil, Chile, Mexico, Uruguay

EU 28, Albania, Macedonia, Norway, Russia, Switzerland, Turkey

MENA countries:

Israel, Jordan, Lebanon, Morocco, Palestinian Territories, Tunisia
}

Figure 19: $\quad$ Share of the total installed capacity in operation (glazed and unglazed water and air collectors) by economic region in 2016 


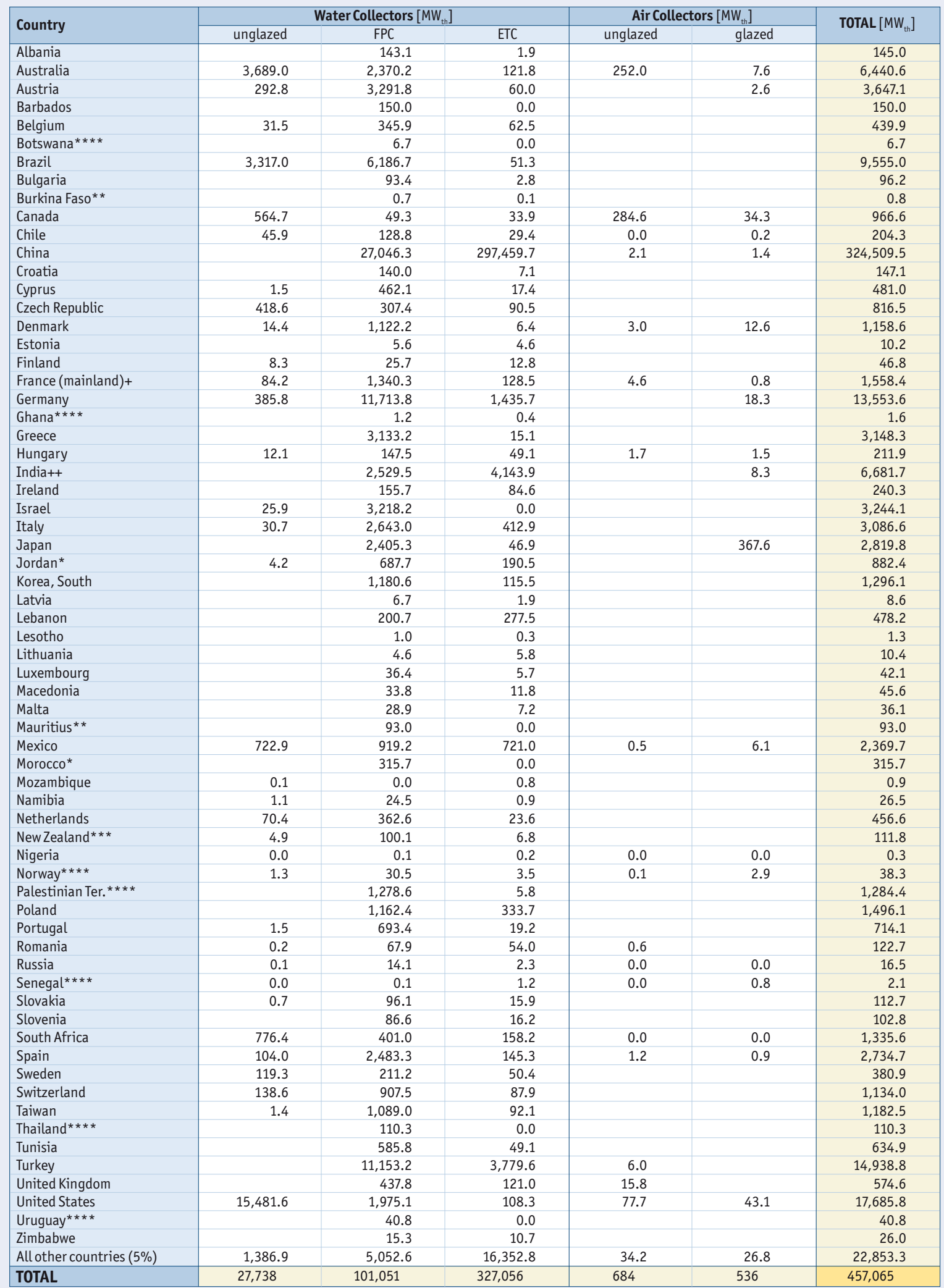

Note: If no data is given: no reliable database for this collector type is available

** Total capacity in operation refers to the year 2015

$* * * *$ Total capacity in operation is based on estimations for new installations in 2016
* Total capacity in operation refers to theyear 2014

*** Total capacityin operation refers to the year 2009

$+\quad$ The figures for France relate to mainland France only, overseas territories of France (DOM) are not considered

Table 3: $\quad$ Total capacity in operation in $2016\left[M W_{\text {th }}\right]$ 


\begin{tabular}{|c|c|c|c|c|c|c|}
\hline \multirow{2}{*}{ Country } & \multicolumn{3}{|c|}{ Water Collectors $\left[\mathrm{m}^{2}\right]$} & \multicolumn{2}{|c|}{ Air Collectors [m²] } & \multirow{2}{*}{$\begin{array}{c}\text { TOTAL (excl. } \\
\text { concentrators) } \\
{\left[\mathrm{m}^{2}\right]}\end{array}$} \\
\hline & unglazed & $\mathrm{FPC}$ & ETC & unglazed & glazed & \\
\hline Albania & & 204,498 & 2,760 & & & 207,258 \\
\hline Australia & $5,270,000$ & $3,386,000$ & 174,000 & 360,000 & 10,800 & $9,200,800$ \\
\hline Barbados & & 214,290 & & & & 214,290 \\
\hline Belgium & 45,000 & 494,083 & 89,250 & & & 628,333 \\
\hline Botswana ${ }^{* * *}$ & & 9,500 & & & & 9,500 \\
\hline Burkina Faso $0^{* * *}$ & & 932 & 139 & & & 1,071 \\
\hline Canada & 806,664 & 70,365 & 48,436 & 406,579 & 48,985 & $1,381,029$ \\
\hline Chile & 65,550 & 184,000 & 42,000 & 0 & 300 & 291,850 \\
\hline China & & $38,637,613$ & $424,942,386$ & 3,000 & 2,000 & $463,584,999$ \\
\hline Croatia & & 200,017 & 10,075 & & & 210,092 \\
\hline Cyprus & 2,213 & 660,120 & 24,800 & & & 687,133 \\
\hline Germany & 551,110 & $16,734,000$ & $2,051,000$ & & 26,100 & $19,362,210$ \\
\hline Ghana**** & & 1,663 & 611 & & & 2,274 \\
\hline Greece & & $4,476,000$ & 21,600 & & & $4,497,600$ \\
\hline Hungary & 17,300 & 210,700 & 70,100 & 2,450 & 2,100 & 302,650 \\
\hline India++ & & $3,613,504$ & $5,919,907$ & & 11,900 & $9,545,311$ \\
\hline Ireland & & 222,420 & 120,831 & & & 343,251 \\
\hline Israel & 37,000 & $4,597,434$ & & & & $4,634,434$ \\
\hline Italy & 43,800 & $3,775,766$ & 589,803 & & & $4,409,369$ \\
\hline Japan & & $3,436,185$ & 67,025 & & 525,149 & $4,028,359$ \\
\hline Jordan* & 5,940 & 982,482 & 272,084 & & & $1,260,506$ \\
\hline Korea, South & & $1,686,558$ & 165,060 & & & $1,851,618$ \\
\hline Latvia & & 9,592 & 2,740 & & & 12,332 \\
\hline Morocco* & & 451,000 & & & & 451,000 \\
\hline Mozambique & 144 & 61 & 1,181 & & & 1,386 \\
\hline Namibia & 1,560 & 34,995 & 1,343 & & & 37,898 \\
\hline Netherlands & 100,564 & 517,991 & 33,650 & & & 652,205 \\
\hline New Zealand ${ }^{* * *}$ & 7,025 & 142,975 & 9,644 & & & 159,645 \\
\hline Nigeria & 0 & 120 & 235 & 0 & 70 & 425 \\
\hline Norway $* * * *$ & 1,849 & 43,624 & 5,032 & 200 & 4,106 & 54,812 \\
\hline Palestinian Ter. ${ }^{* * * *}$ & & $1,826,625$ & 8,225 & & & $1,834,850$ \\
\hline Poland & & $1,660,500$ & 476,700 & & & $2,137,200$ \\
\hline Portugal & 2,130 & 990,522 & 27,480 & & & $1,020,132$ \\
\hline Romania & 340 & 97,000 & 77,150 & 800 & & 175,290 \\
\hline Russia & 137 & 20,203 & 3,251 & 2 & 64 & 23,657 \\
\hline Senegal ${ }^{* * * *}$ & 0 & 87 & 1,648 & 0 & 1,145 & 2,879 \\
\hline Slovakia & 1,000 & 137,350 & 22,750 & & & 161,100 \\
\hline Slovenia & & 123,650 & 23,150 & & & 146,800 \\
\hline South Africa & $1,109,093$ & 572,836 & 226,070 & 0 & 0 & $1,907,999$ \\
\hline Spain & 148,520 & $3,547,629$ & 207,639 & 1,750 & 1,250 & $3,906,788$ \\
\hline Sweden & 170,410 & 301,674 & 72,070 & & & 544,154 \\
\hline Switzerland & 198,050 & $1,296,480$ & 125,620 & & & $1,620,150$ \\
\hline Taiwan & 1,937 & $1,555,672$ & 131,539 & & & $1,689,148$ \\
\hline Thailand ${ }^{* * * *}$ & & 157,536 & & & & 157,536 \\
\hline Tunisia & & 836,792 & 70,104 & & & 906,896 \\
\hline Turkey & & $15,933,182$ & $5,399,454$ & 8,570 & & $21,341,206$ \\
\hline United Kingdom & & 625,375 & 172,794 & 22,600 & & 820,769 \\
\hline United States & $22,116,619$ & $2,821,556$ & 154,711 & 111,068 & 61,500 & $25,265,453$ \\
\hline
\end{tabular}

Note: If no data is given: no reliable database for this collector type is available * * Total capacity in operation refers to the year 2015

**** Total capacity in operation is based on estimations for newinstallations in 2016
* Total capacity in operation refers to theyear 2014

*** Total capacityin operation refers to the year 2009

+ The figures for France relate to mainland France only, overseas territories of France (DOM) are not considered

Table 4: $\quad$ Total installed collector area in operation in $2016\left[\mathrm{~m}^{2}\right]$ 
The total installed capacity in operation in 2016 was divided into flat plate collectors (FPC): $101.1 \mathrm{GW}_{\text {th }}$ (144.4 million square meters), evacuated tube collectors (ETC): $327.1 \mathrm{GW}_{\text {th }}$ (467.2 million square meters), unglazed water collectors $27.7 \mathrm{GW}_{\text {th }}$ (39.6 million square meters), and glazed and unglazed air collectors: $1.2 \mathrm{GW}_{\text {th }}(1.7 \text { million square meters })^{22}$.

With a global share of $71.5 \%$, evacuated tube collectors were the predominant solar thermal collector technology, followed by flat plate collectors with $22.1 \%$ and unglazed water collectors with $6.1 \%$. Air collectors play only a minor rolein the total numbers (Figure 20).

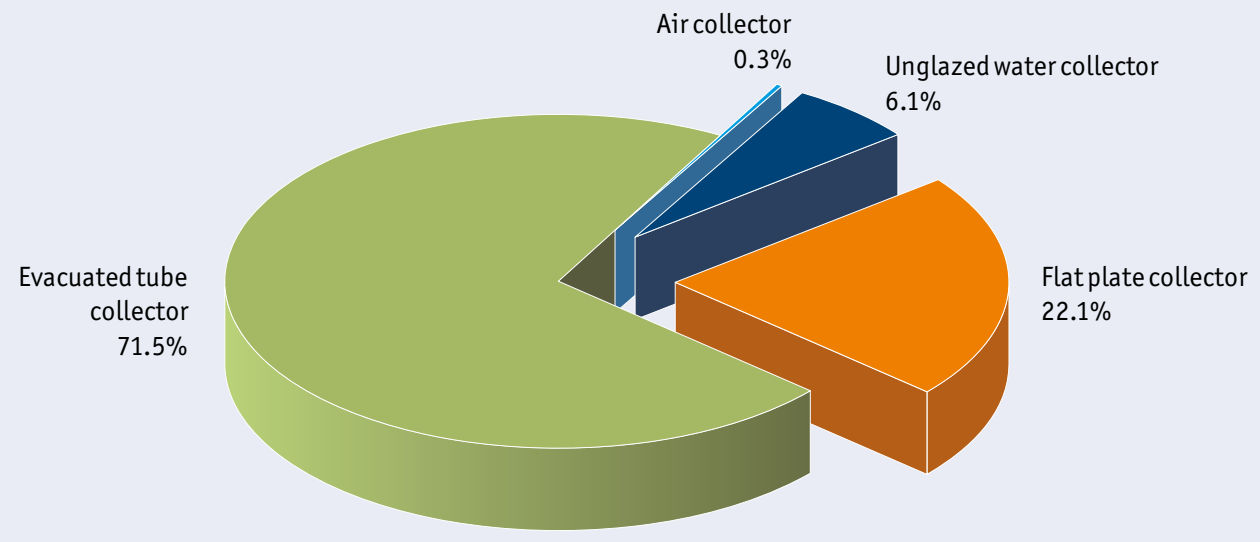

Figure 20: $\quad$ Distribution of the total installed capacity in operation by collector type in 2016 - WORLD

By contrast in Europe, the second largest market to China, flat plate collectors were the dominant collector type (Figure 21). Compared to 2015 the share of evacuated tube collectors increased in Europe by $1.8 \%$.

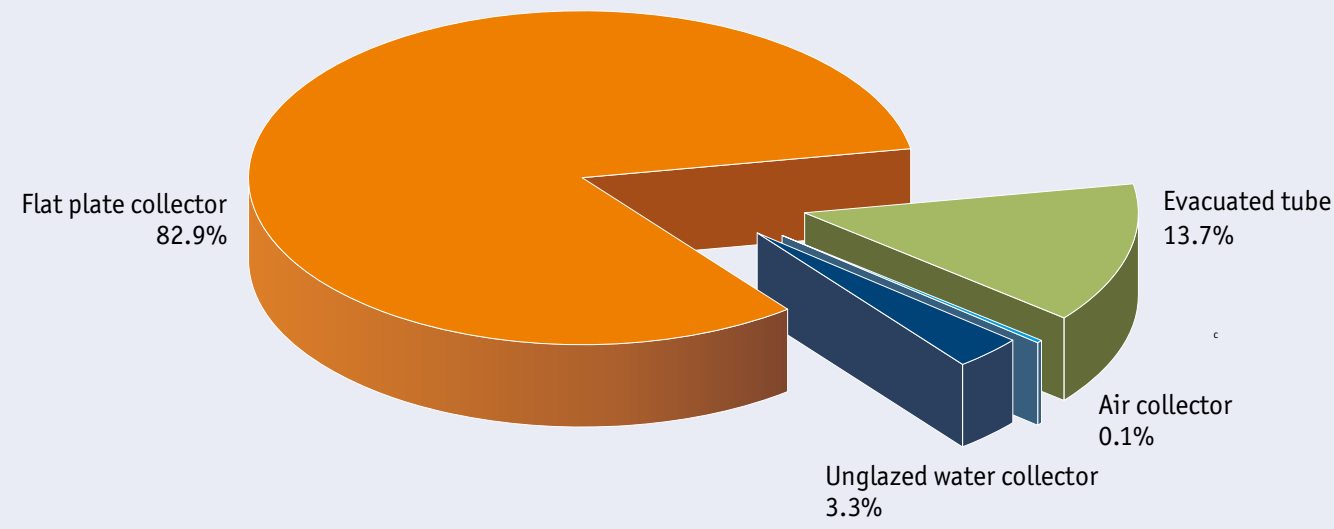

Figure 21: Distribution of the total installed capacity in operation by collector type in 2016 - EUROPE 
Figure 22 shows the cumulated installed capacity of glazed and unglazed water collectors in operation for the 10 leading markets in 2016 in total numbers.

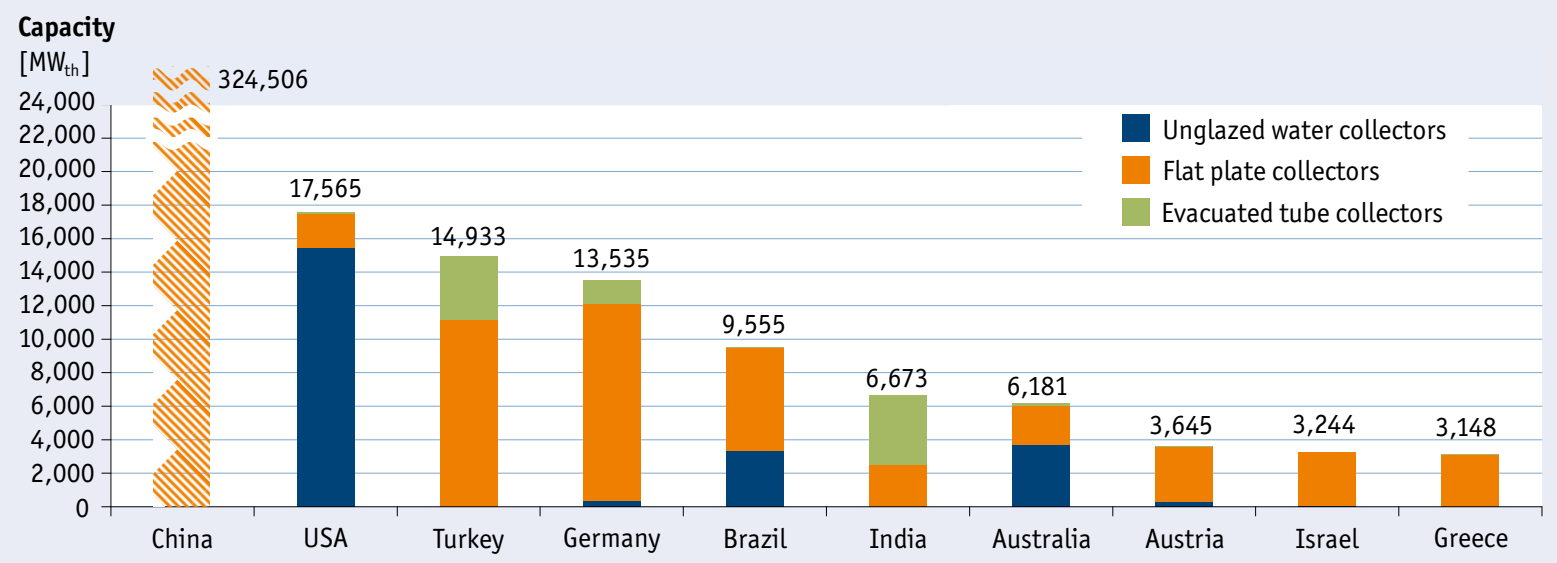

Figure 22: Top 10 countries of cumulated water collector installations (absolute figures in $M W_{\text {th }}$ ) 2016

Compared to the year 2015, the top 10 countries remained unchanged. However, Turkey overtook Germany in 2015 and now holds the number three position and India overtook Australia in 2015 and improved its position from seventh position to position six. This shows the trend of the last years that non-OECD countries are taking over more and more the top positions.

China remained the world leader in total capacity, and its market is dominated by evacuated tube collectors. The United States held its second position due to the high number of installed unglazed water collectors. Only Australia and to some extent Brazil play an important role with respect to unglazed water collectors besides the United States. In the large European markets Germany, Austria and Greece flat plate collectors were the most important collector technology. A strong trend towards evacuated tube collector technology can be seen in Turkey and Israel over the past several years.

The top 10 countries with the highest market penetration per capita changed compared to 2015. The leading countries in cumulated glazed and unglazed water collector capacity in operation in 2016 per 1,000 inhabitants were Barbados (515 kW

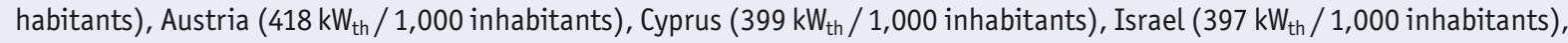
Greece (292 kW th $/ 1,000$ inhabitants), the Palestinian territories (289 kW th / 1,000 inhabitants), Australia (269 kW th $/ 1,000$ inhabitants), China (236 kW th / 1,000 inhabitants), Denmark (204 kW th / 1,000 inhabitants) and Turkey (186 kW th $/ 1,000$ inhabitants). Denmark overtook Turkey due to a lot of large district heating systems installed in 2016.

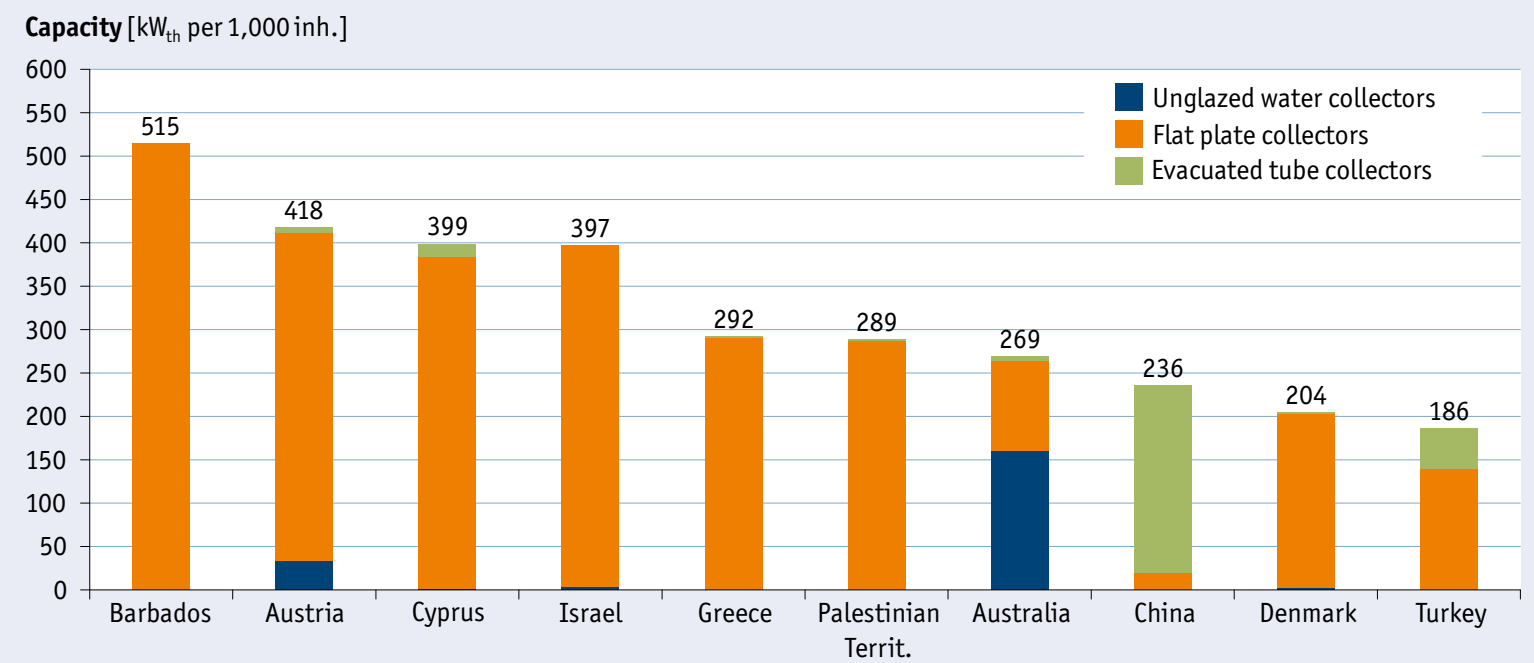

Figure 23: $\quad$ Top 10 countries of cumulated water collector installations (relative figures in $k W_{\text {th }}$ per 1,000 inhabitants) 2016 
With $324.5 \mathrm{GW}_{\text {th }}$, China was still by far the leader in terms of total installed capacity of glazed water collectors in 2016. With $>10 \mathrm{GW}_{\text {th }}$ of installed capacity, Turkey and Germany were next. Several countries, namely India, Brazil, Austria, Israel, Greece, Italy, Spain, Australia, Japan, the United States, Mexico, Poland, France, South Korea, the Palestinian Territories, and Taiwan had more than $1 \mathrm{GW}_{\text {th }}$ of water collectors installed by the end of 2016 (Figure 24).

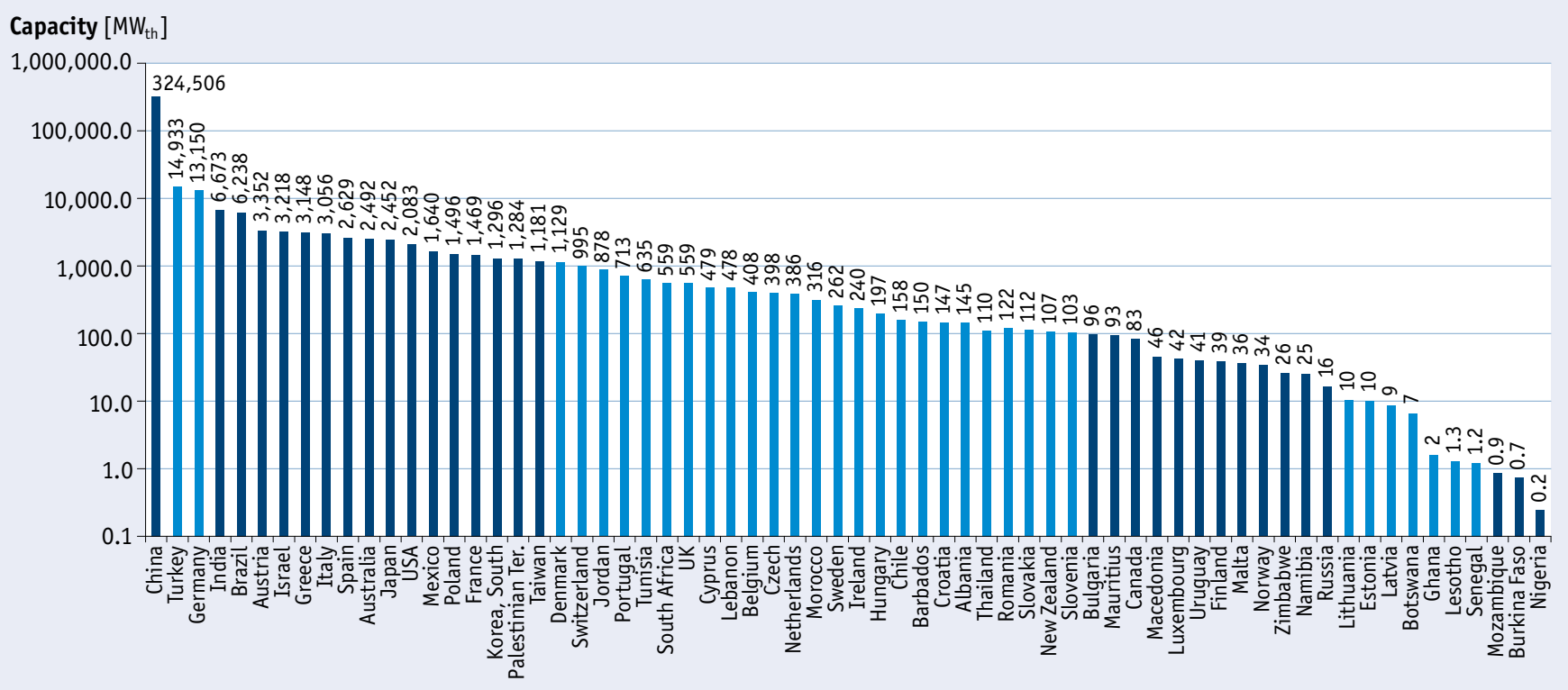

Figure 24: $\quad$ Total capacity of glazed water collectors in operation by the end of 2016

In terms of total installed capacity of glazed water collectors in operation per 1,000 inhabitants, there was a continued dominance by five countries: Barbados, Cyprus, Israel, Austria and Greece. China ranks seventh in terms of market penetration. Nevertheless, it is remarkable that China with its 1.37 billion inhabitants exceeds solar thermal per capacity levels of the large European markets in Germany, Turkey, Denmark and Spain (Figure 25).

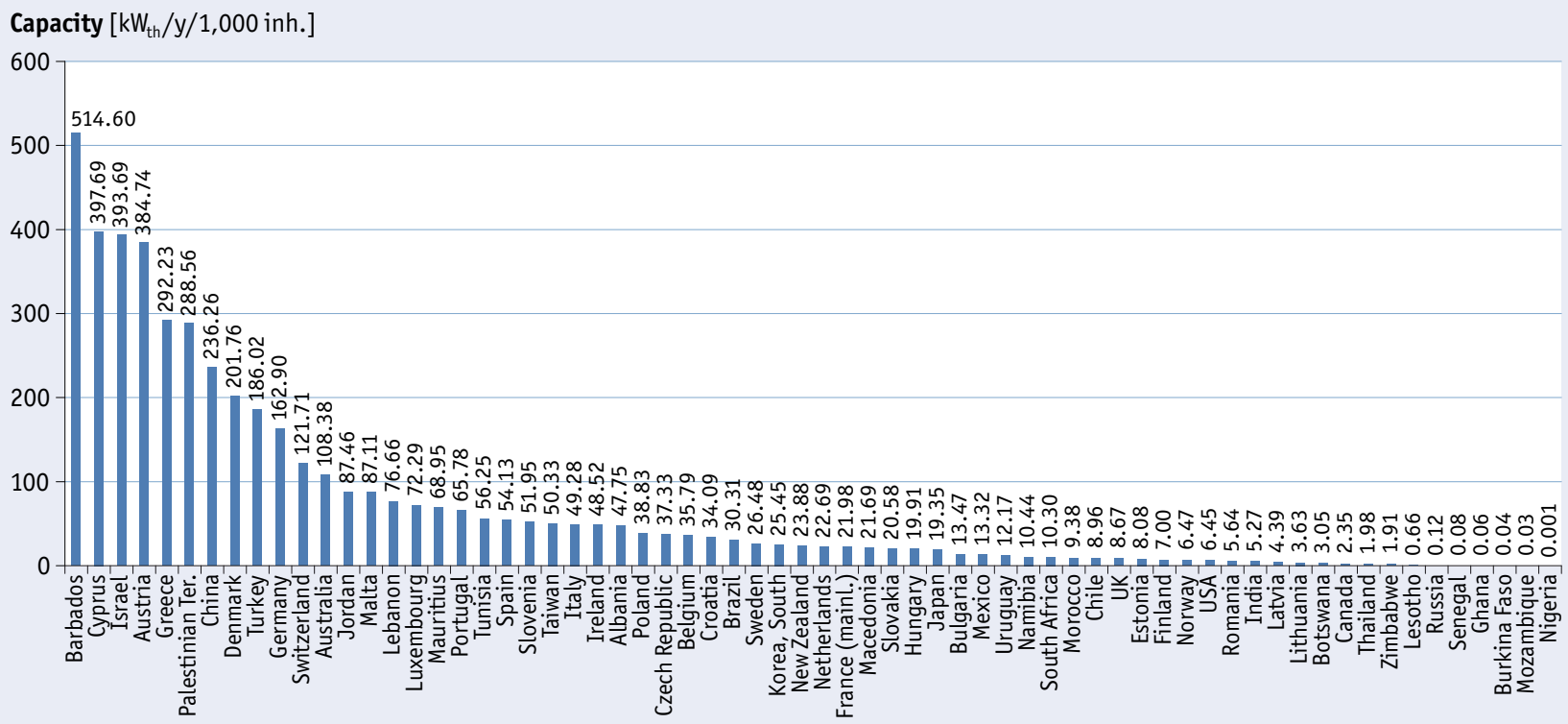

Figure 25: $\quad$ Total capacity of glazed water collectors in operation in $k W_{\text {th }}$ per 1,000 inhabitants in 2016 
The following figures show the solar thermal market penetration per capita worldwide and in Europe.

\section{Cumulated installed capacity in kW per 1,000 inhabitants (2016)}
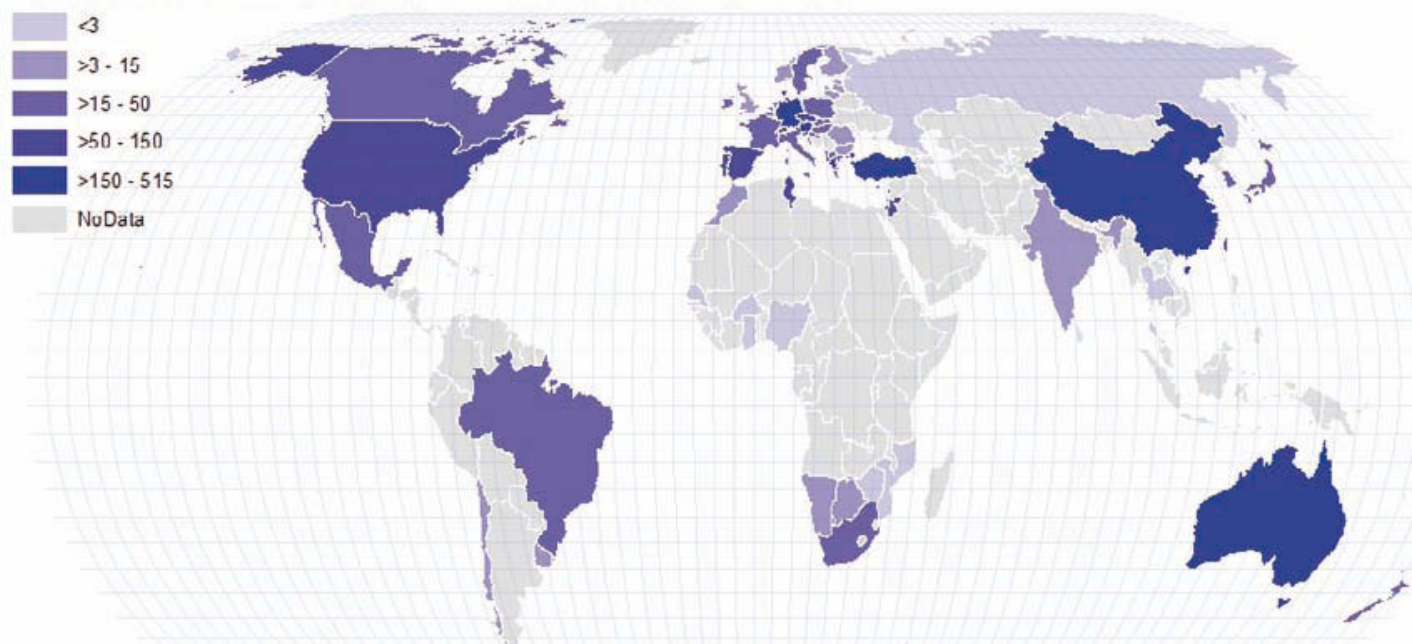

Figure 26: $\quad$ Solar thermal market penetration per capita worldwide in $\mathrm{kW}_{\text {th }}$ per 1,000 inhabitants

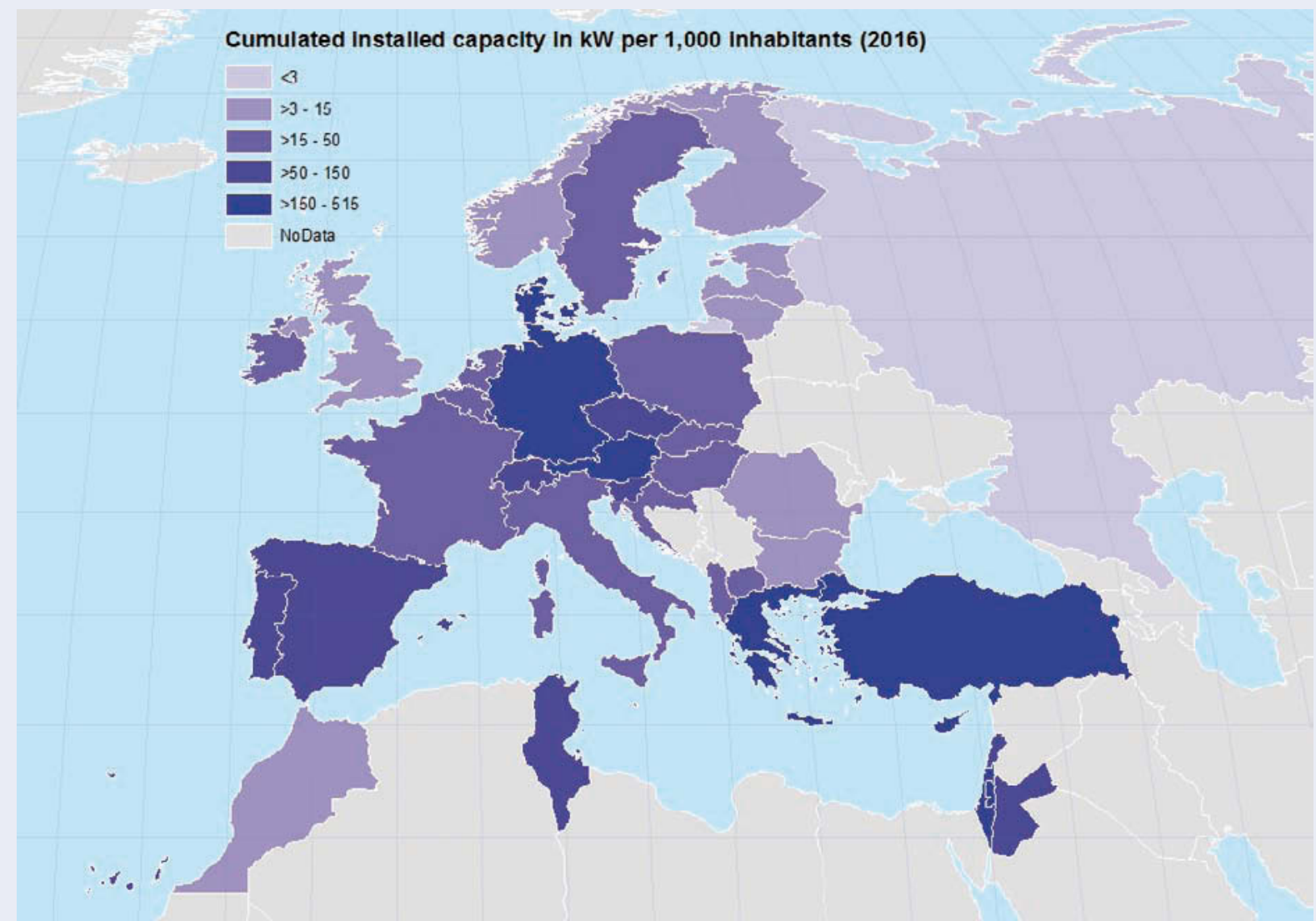

Figure 27: $\quad$ Solar thermal market penetration per capita in Europe in $k W_{\text {th }}$ per 1,000 inhabitants 


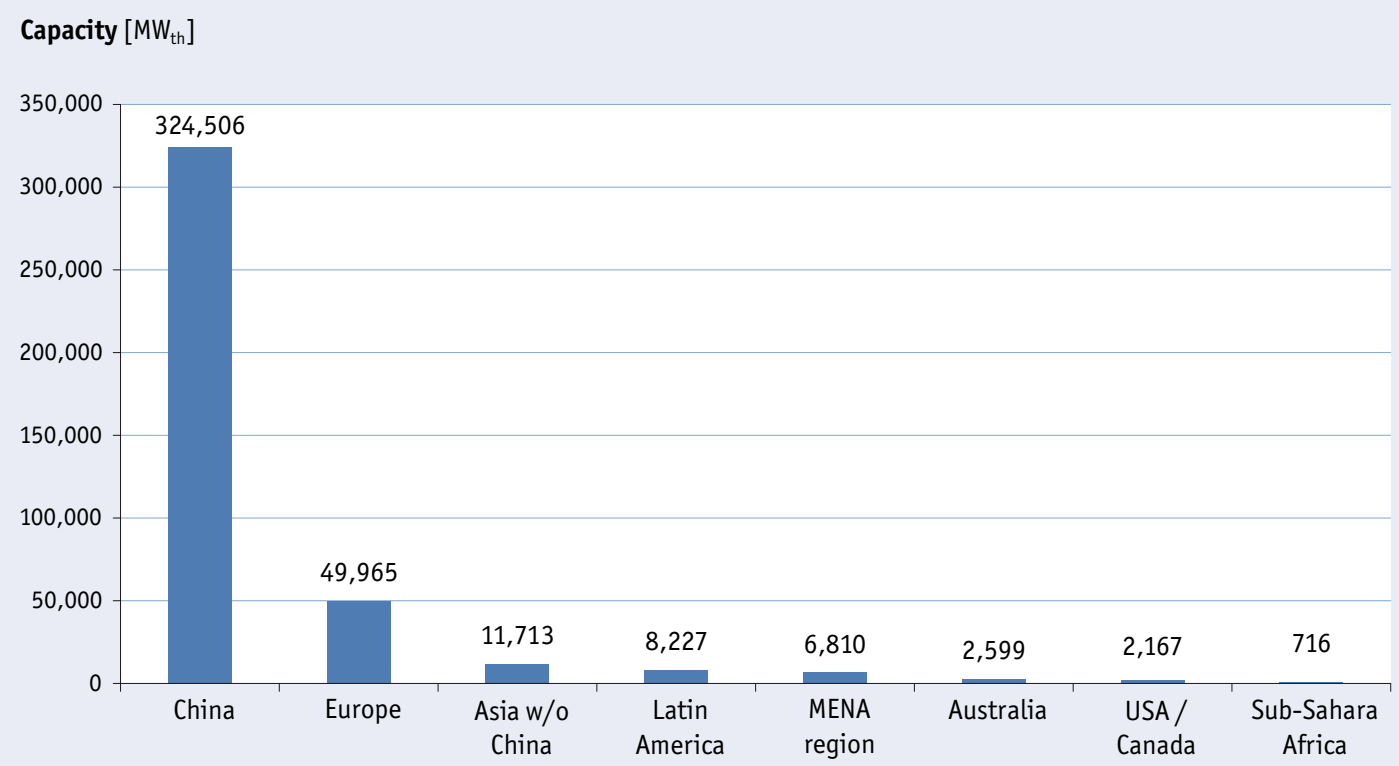

Figure 28: $\quad$ Total capacity of glazed flat plate and evacuated tube collectors in operation by economic region in 2016

In terms of market penetration per capita by economic region, China again takes the lead. It is remarkable that the MENA countries and also Australia are ahead of Europe (Figure 29) and shows the very unbalanced market distribution in Europe. Whereas some European countries like Cyprus, Austria and Greece belong to the world market leaders in terms of high market penetration, others like the Baltic countries have negligible solar thermal market penetrations.

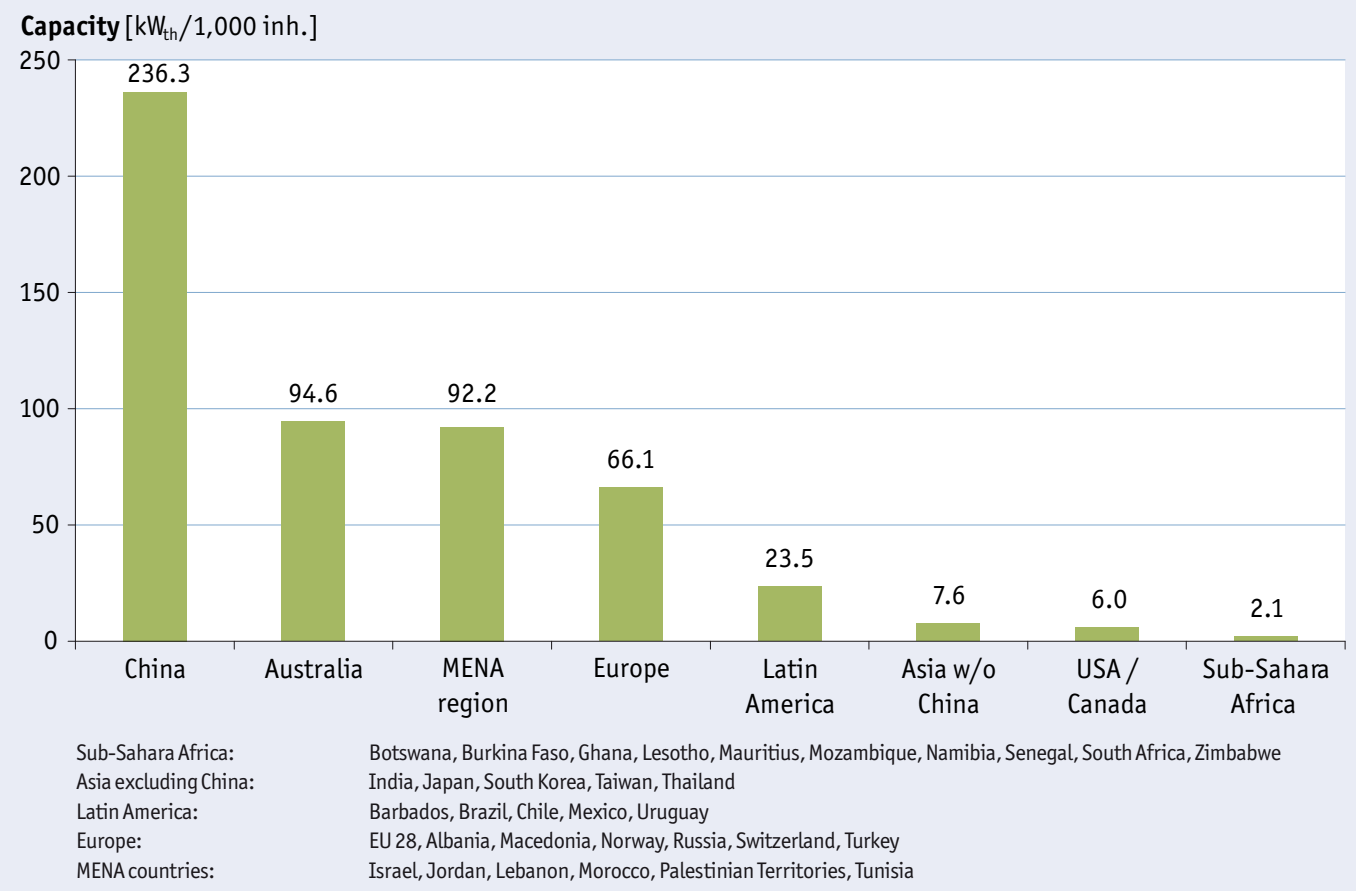

Figure 29: Total capacity of glazed flat plate and evacuated tube collectors in operation by economic region and in $k W_{\text {th }}$ per 1,000 inhabitants in 2016 


\subsection{Total capacity of unglazed water collectors in operation}

Unglazed water collectors are mainly used for swimming pool heating. This type of collector has losta significant market share over the past decade. The share of unglazed water collectors in the total installed collector capacity was reduced from $21 \%{ }^{23}$ in 2005 to just $6 \%$ in 2016. Figure 30 and Figure 31 show the total installed capacity of unglazed water collectors and total installed capacity of unglazed water collectors per 1,000 inhabitants by end of the year 2016.

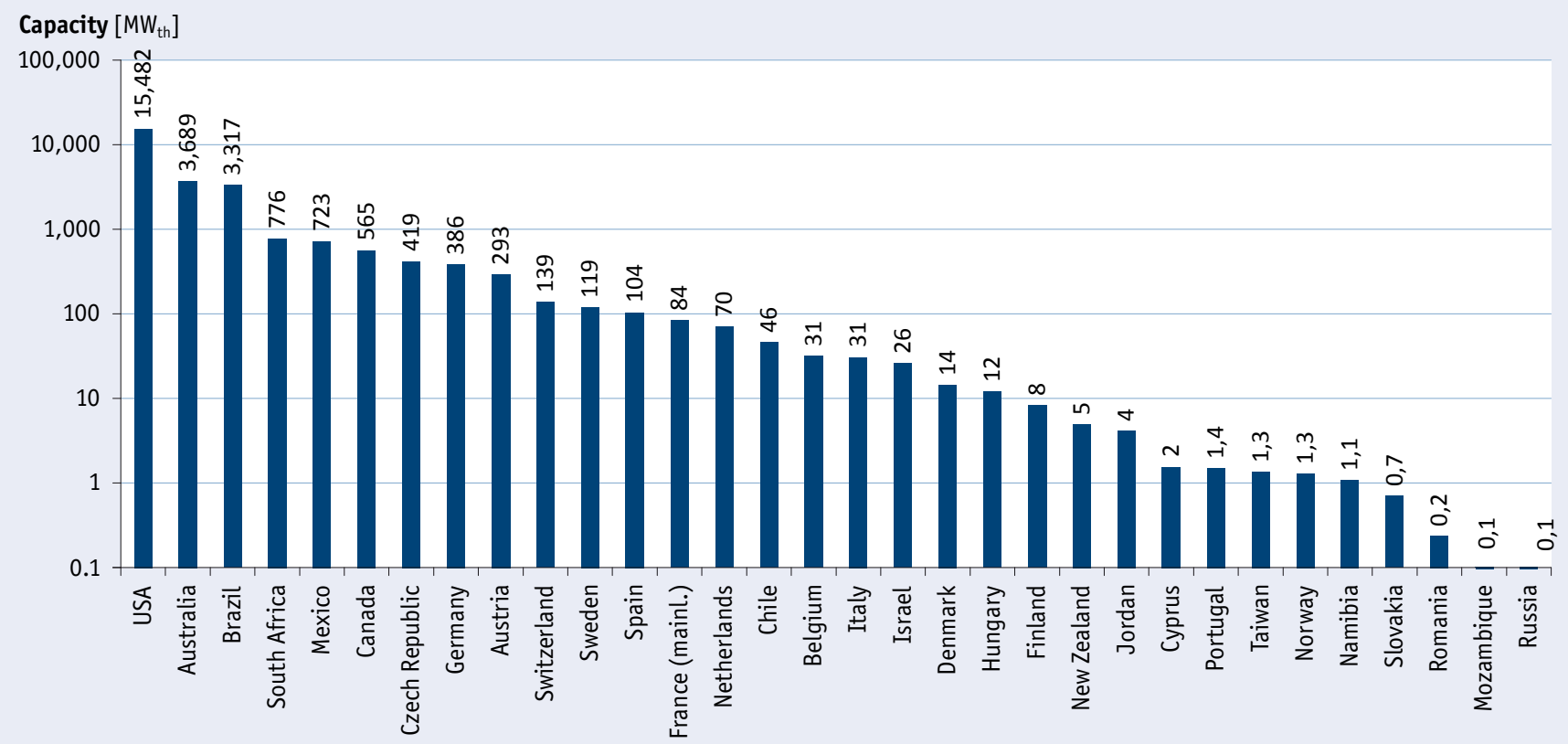

Figure 30: Total capacity of unglazed water collectors in operation in 2016

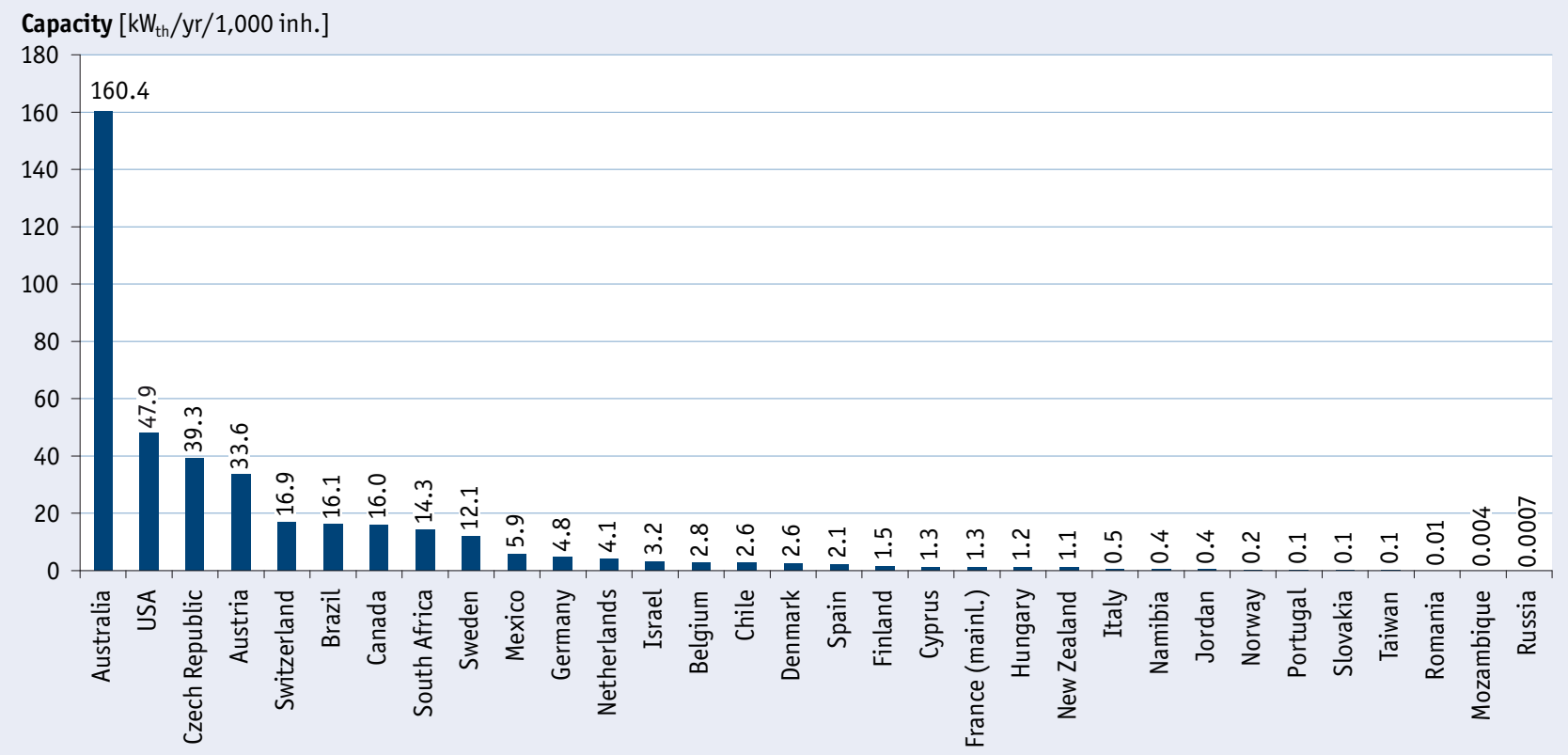

Figure 31: Total capacity of unglazed water collectors in operation in $k W_{\text {th }}$ per 1,000 inhabitants in 2016

23 Solar Heat Worldwide (Ed.2008), Figure 3 


\section{5 \\ Newly installed capacity in 2016 and market development}

In the year 2016, a total capacity of $36.5 \mathrm{GW}$ th, corresponding to 52.2 million square meters of solar collectors was installed worldwide. This means a decrease in new collector installations by $9 \%$ compared to the year 2015.

The main markets were in China (27.7 GW $\mathrm{Gh}_{\text {th }}$ ) and Europe (3.2 $\mathrm{GW}_{\text {th }}$ ), which together accounted for $85 \%$ of the overall new collector installations in 2016. The rest of the market was shared between Latin America (1.2 $\left.\mathrm{GW}_{\mathrm{th}}\right)$, Asia excluding China (1.0 GW $\left.\mathrm{Gh}_{\mathrm{th}}\right)$, the United States and Canada $\left(0.7 \mathrm{GW}_{\mathrm{th}}\right)$, the MENA countries $\left(0.4 \mathrm{GW}_{\mathrm{th}}\right)$, Australia $\left(0.4 \mathrm{GW}_{\mathrm{th}}\right)$, and the Sub-Sahara African countries $\left(0.1 \mathrm{GW}_{\text {th }}\right)$. The market volume of "all other countries" is estimated to amount to $5 \%$ of the new installations $\left(1.8 \mathrm{GW}_{\text {th }}\right)$.

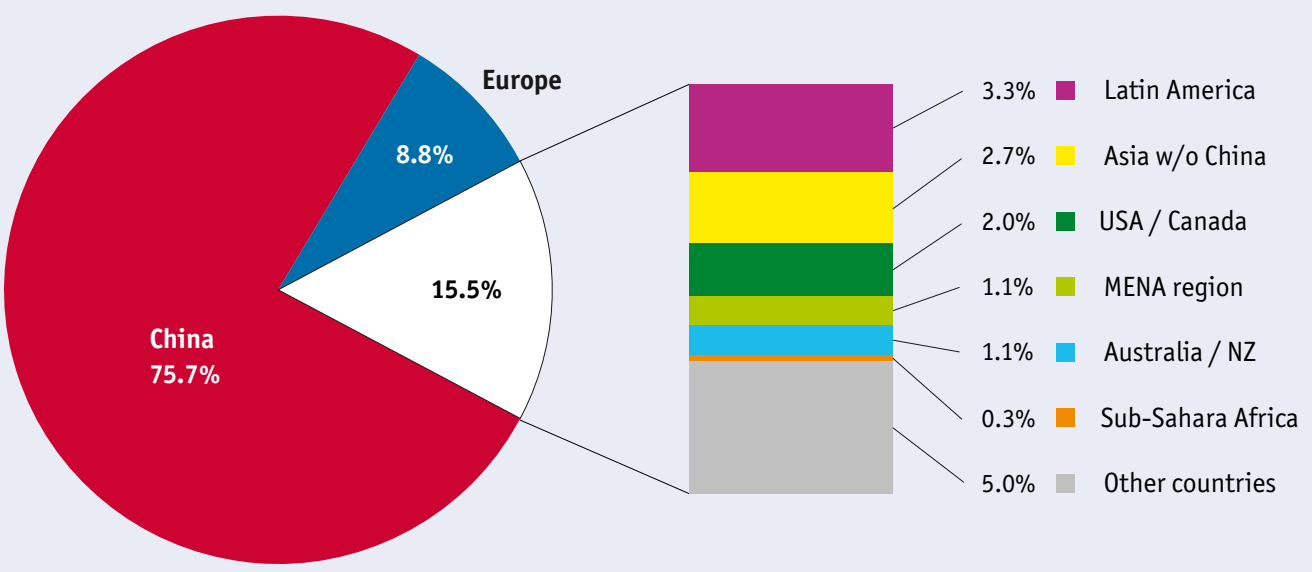

Sub-Sahara Africa: Botswana, Burkina Faso, Ghana, Lesotho, Mauritius, Mozambique, Namibia, Nigeria, Senegal, South Africa, Zimbabwe Asia excluding China: India, Japan, Korea South, Taiwan, Thailand Latin America: $\quad$ Barbados, Brazil, Chile, Mexico, Uruguay

Europe: $\quad$ EU 28, Albania, Macedonia, Norway, Russia, Switzerland, Turkey

MENA countries: $\quad$ Israel, Lebanon, Palestinian Territories, Tunisia

Figure 32: $\quad$ Share of newly installed capacity (glazed and unglazed water and air collectors) by economic regions in 2016

From the top 10 markets in 2016 a positive market development was reported only from Denmark ( $90 \%$ compared to 2015 due to large solar district heating systems installed in 2016) and Mexico (6\%). The other major solar thermal markets within the top 10 countries suffered market declines. 


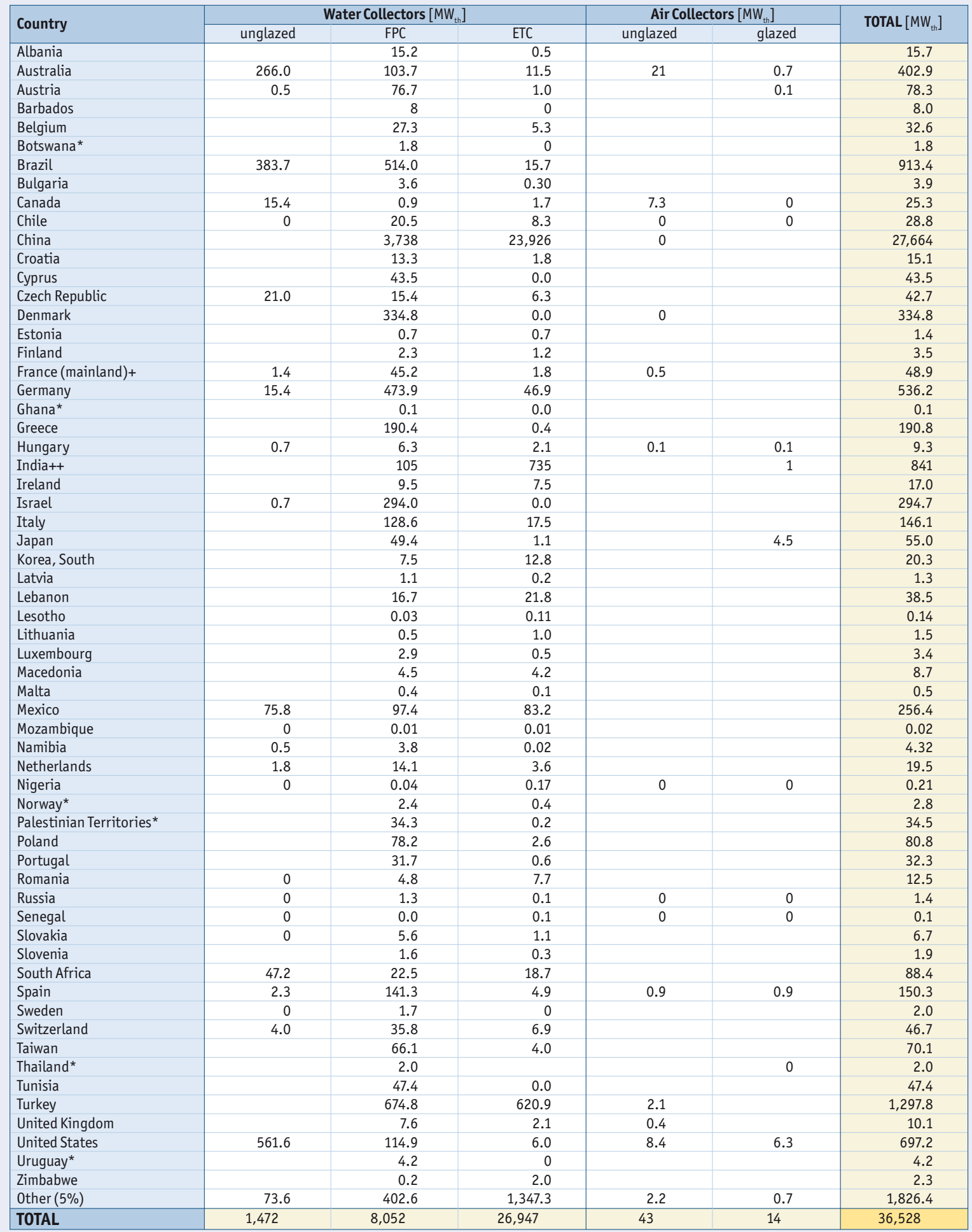

Note: If no data is given: no reliable database for this collector type is available.

* Country market data for new installations in 2016 estimated by AEE INTEC ( $\%$ growth rate assumed)

$+\quad$ The figures for France relate to mainland France only, overseas territories of France (DOM) are not considered

++ Since 2016 the figures for India refer to calendaryear

Table 5: $\quad$ Newly installed capacity in $2016\left[M W_{\text {th }} /\right.$ a $]$ 


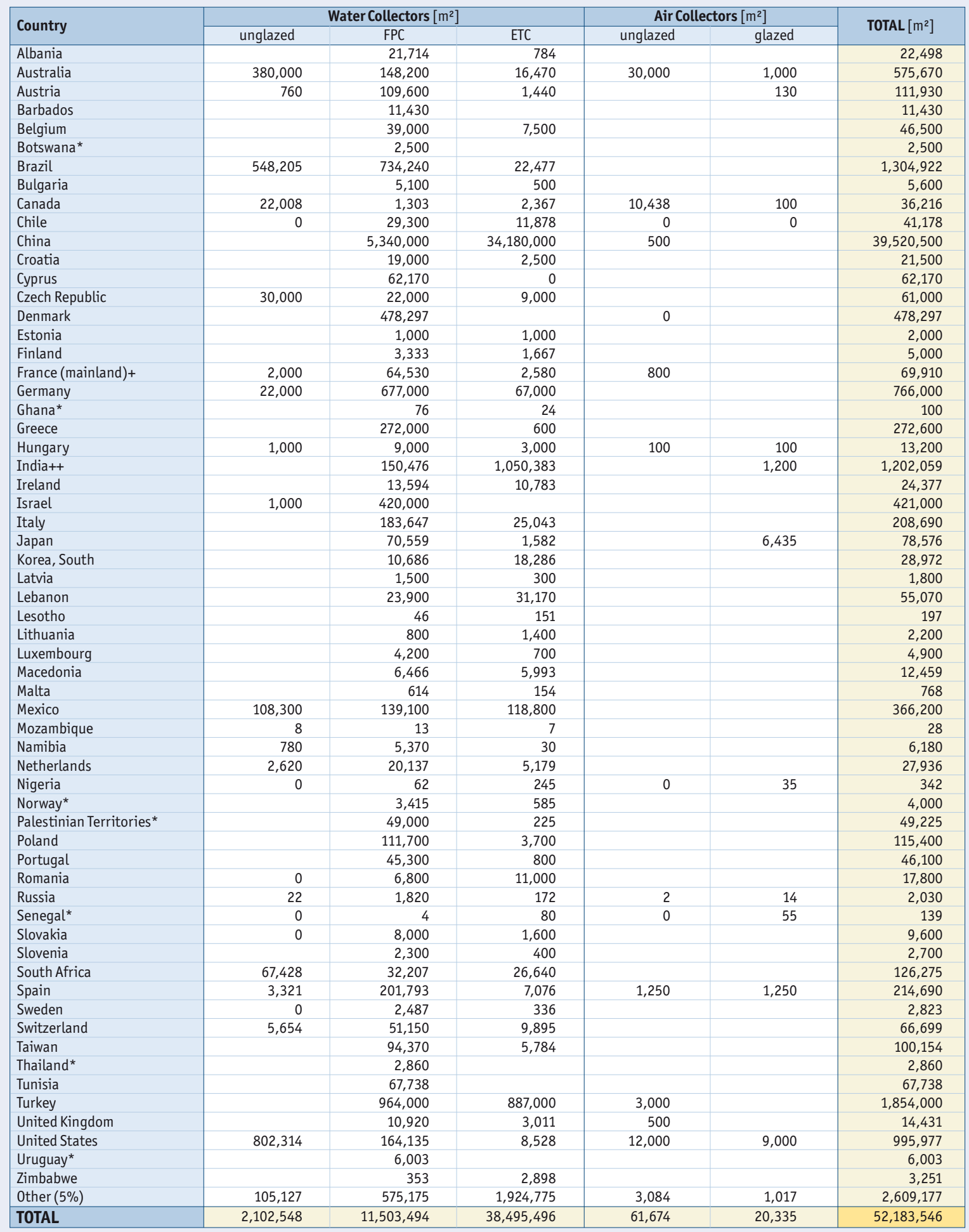

Note: If no data is given: no reliable database for this collector type is available.

* Country market data for new installations in 2015 estimated by AEEINTEC ( $\%$ growth rate assumed)

$+\quad$ The figures for France relate to mainland France only, overseas territories of France (DOM) are not considered

++ Since 2016 the figures for India refer to calendar year

Table 6: $\quad$ Newly installed collector area in $2016\left[\mathrm{~m}^{2} / \mathrm{a}\right]$ 
New installations in 2016 are divided into flat plate collectors: $8.1 \mathrm{GW}_{\text {th }}$ (11.5 million square meters), evacuated tube collectors: $26.9 \mathrm{GW}_{\text {th }}$ (38.5 million square meters), unglazed water collectors: $1.5 \mathrm{GW}_{\text {th }}$ (2.1 million square meters), and glazed and unglazed air collectors: $0.06 \mathrm{GW}_{\text {th }}$ (0.1 million square meters).

With a share of $73.8 \%$, evacuated tube collectors remain by far the most important solar thermal collector technology worldwide (Figure 33). In a global context, this breakdown is mainly driven by the dominance of the Chinese market where around $87 \%$ of all newly installed collectors in 2016 were evacuated tube collectors. Nevertheless, it is notable that the share of evacuated tube collectors decreased from about $82 \%$ in 2011 to $73.8 \%$ in 2016 and in the same time frame flat plate collectors increased their share from $14.7 \%$ to $22 \%$.

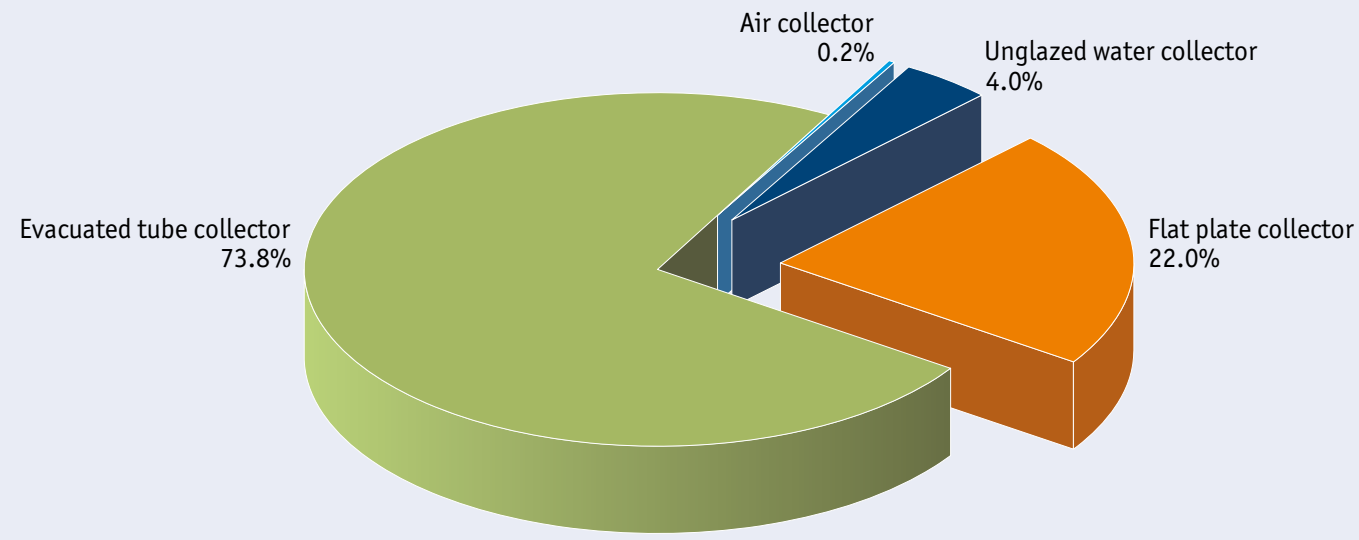

Figure 33: Distribution of the newly installed capacity by collector type in 2016 - WORLD

In Europe, the situation is almost the opposite compared to China with $74.9 \%$ of all solar thermal collectors installed in 2016 being flat plate collectors (Figure 34). In the medium term perspective, the share of flat plate collectors decreased in Europe from $81.5 \%$ in 2011 to $74.9 \%$ in 2016. While driven mainly by the markets in Turkey, Poland, Switzerland and Germany, evacuated tube collectors increased their share in Europe between 2011 and 2016 from $15.6 \%$ to $23.5 \%$. In theyear 2016 the share of evacuated tube collectors decreased again compared to the year 2015 from $26.1 \%$ in 2015 to $23.5 \%$ in 2016 .

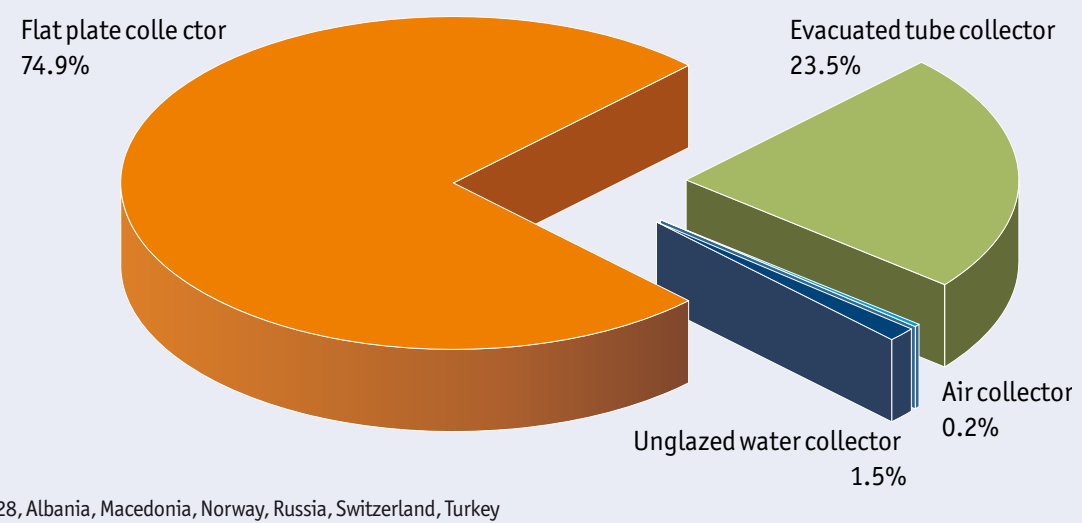

Figure 34: $\quad$ Distribution of the newly installed capacity by collector type in 2016 - EUROPE 
Figure 35 shows the newly installed capacity of glazed and unglazed water collectors for the 10 leading markets in 2016 in total numbers. China remained the market leader in absolute terms followed by Turkey. Brazil overtook India and ranks in the third position in 2016. Denmark pushed Poland out of the top 10 due to the large number of solar district heating systems installed in 2016. Germany faced a significant market decline the fourth year in a row, but held on to its sixth position rank.

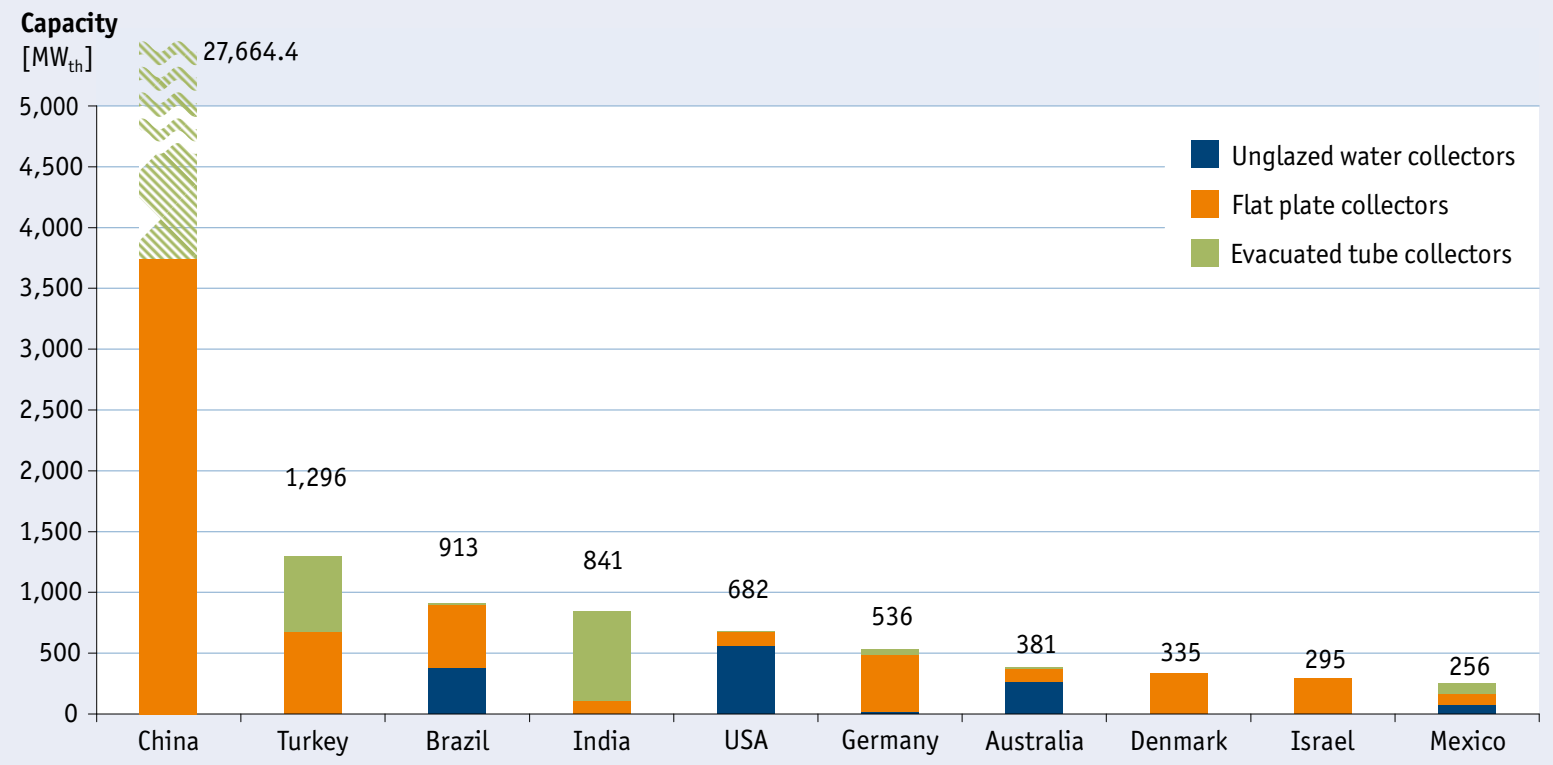

Figure 35: $\quad$ Top 10 markets for glazed and unglazed water collectors in 2016 (absolute figures in MWth)

In terms of newly installed solar thermal capacity per 1,000 inhabitants in 2016, the top 10 countries are shown in Figure 40. The fast climber in 2016 was Denmark, which took the lead. Israel and Cyprus were second. The other rankings stayed unchanged compared to 2015.

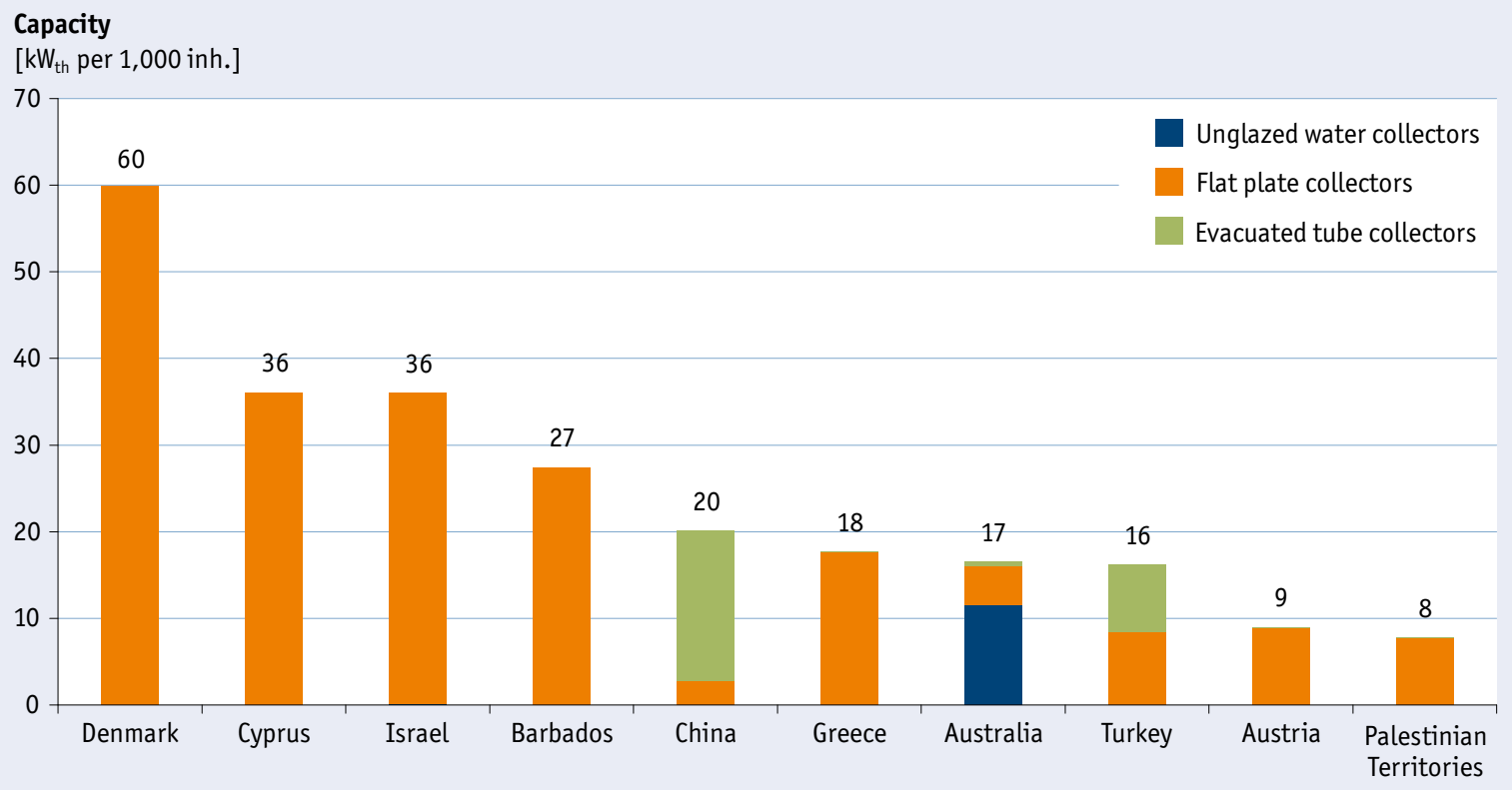

Figure 36: Top 10 markets for glazed and unglazed water collectors in 2016 (in $k W_{\text {th }}$ per 1,000 inhabitants) 


\section{6 \\ Newly installed capacity of glazed water collectors}

In 2016 glazed water collectors accounted for $95.9 \%$ of the total newly installed capacity and with a market share of $79 \%$. China was the most influential market in the global context (Figure 37).

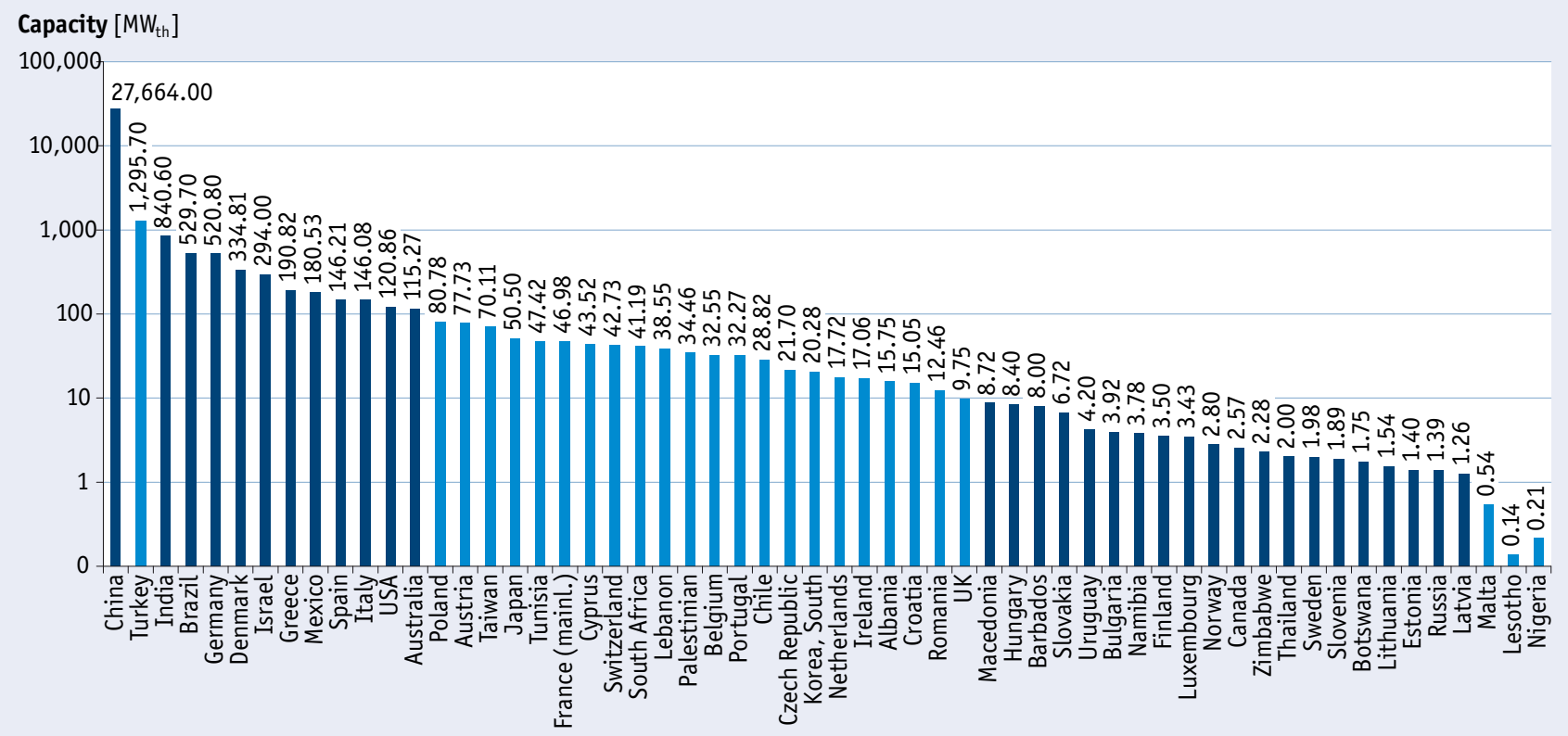

Figure 37: $\quad$ Newly installed capacity of glazed water collectors in 2016

In terms of newly installed glazed water collector capacity per 1,000 inhabitants, Denmark is the leader ahead of Cyprus and Israel. In this respect China ranks in the place (Figure 38).

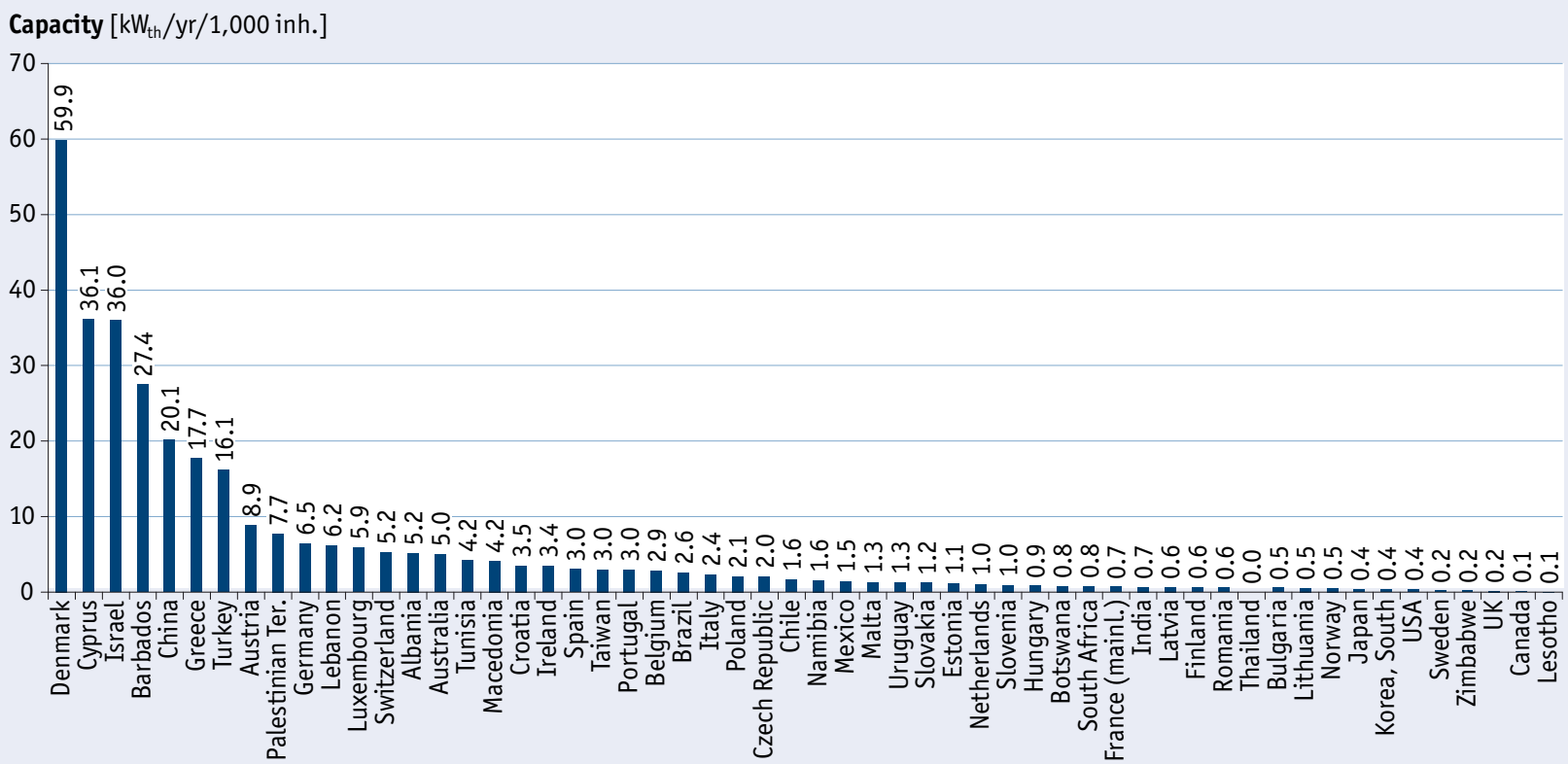

Figure 38: $\quad$ Newly installed capacity of glazed water collectors in 2016 in $k W_{\text {th }}$ per 1,000 inhabitants 
The following figures show the solar thermal market penetration per capita of the newly installed capacity in 2016 worldwide and in Europe.

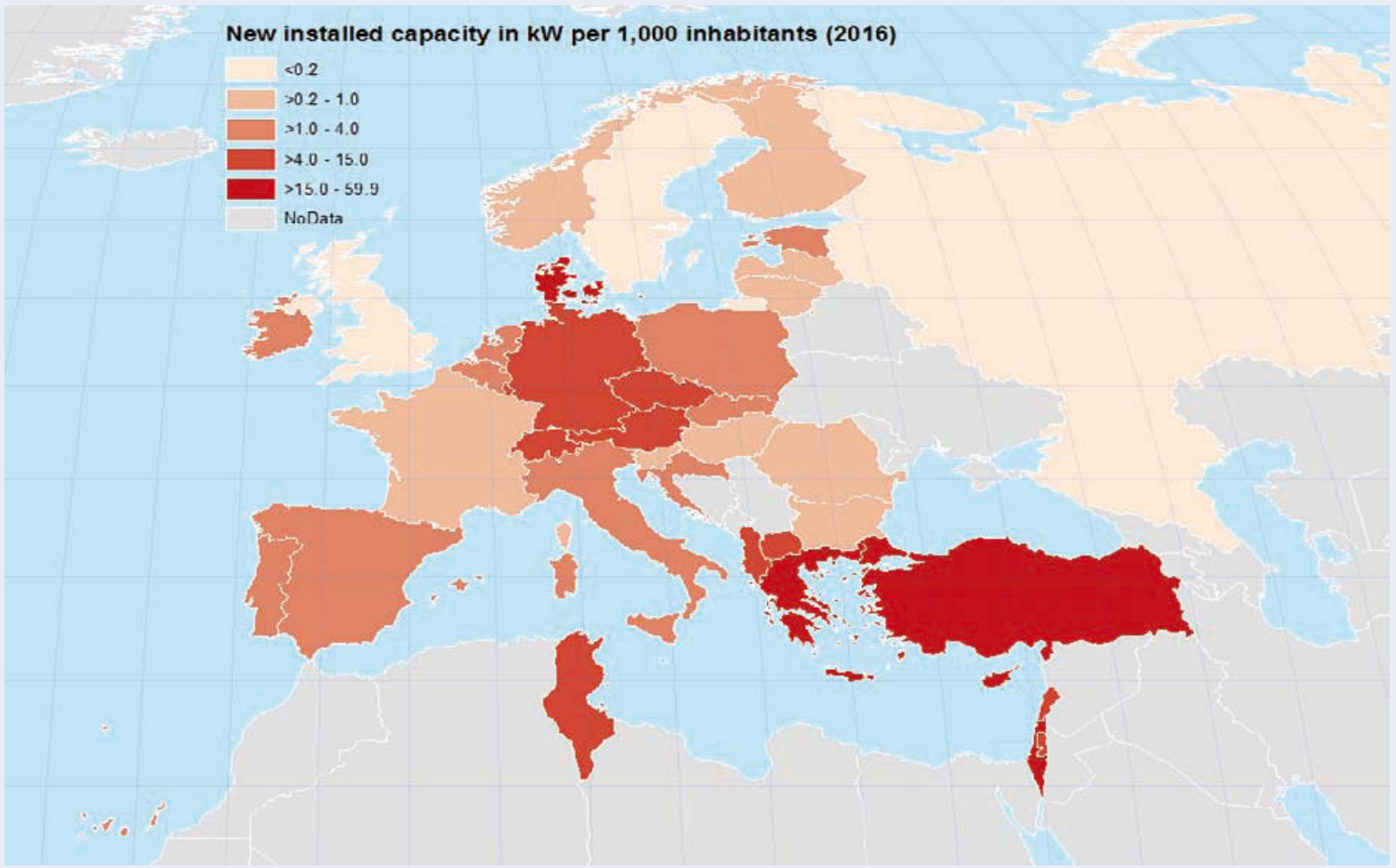

Figure 39: $\quad$ Installed capacity in Europe in 2016 in $k W_{\text {th }}$ per 1,000 inhabitants

New installed capacity in kW per 1,000 inhabitants (2016)

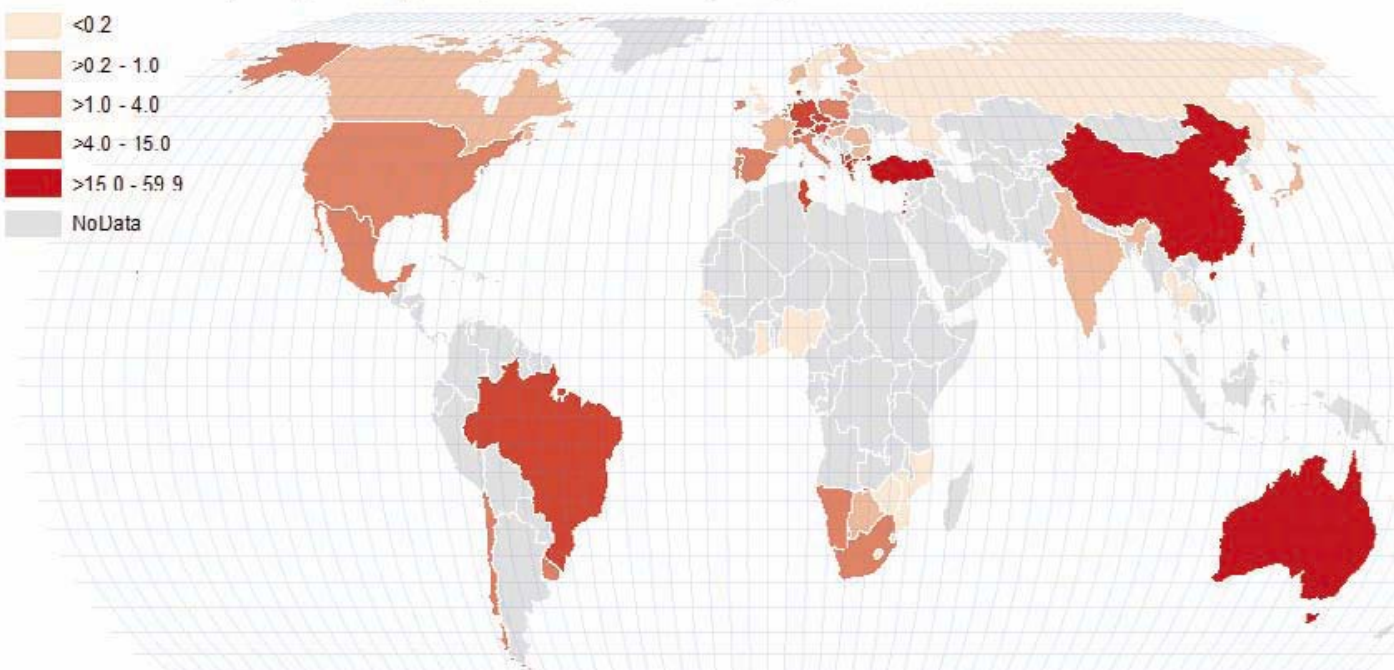

Figure 40: $\quad$ Installed capacity worldwide in 2016 in $\mathrm{kW}$ th per 1,000 inhabitants 


\section{7 Market development of glazed water collectors between 2000 and 2016}

The worldwide market of glazed water collectors was characterized by a steady upwards trend between 2000 and 2011 and showed a leveling trend in 2012 and 2013 at around $53 \mathrm{GW}$ th. In 2014, a significant market decline of $-15.6 \%$ was reported for the first time since the year 2000. This trend continued in 2015 and 2016, but the markets seem to have recovered slightly as the decline slowed down.

The newly installed glazed water collector capacity in 2016 amounted to $35 \mathrm{GW}_{\text {th }}$ (Figure 41).

Capacity $\left[\mathrm{GW}_{\mathrm{th}}\right]$

Growth rate [-]

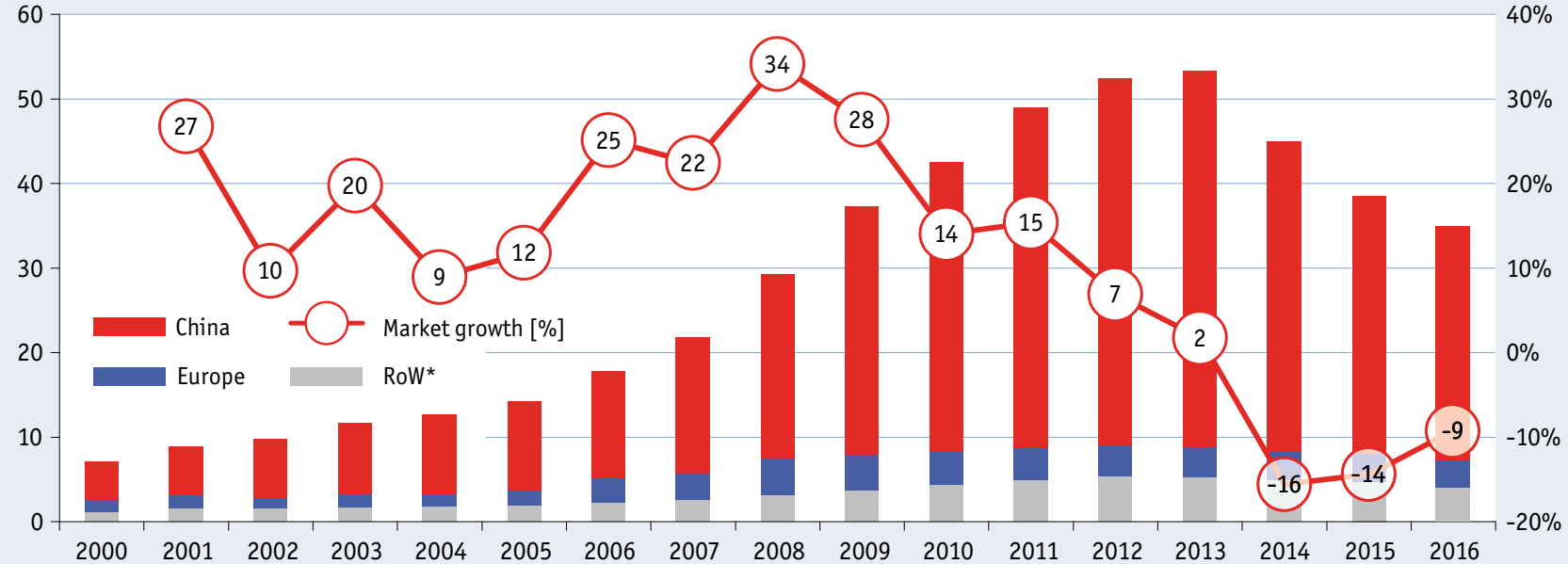

Figure 41: $\quad$ Global market development of glazed water collectors from 2000 to 2016

In 2000 the Chinese market was about three times as large as the European market while in 2016 the Chinese market exceeded the European market nine-fold (Figure 42).

It can also be seen in Figure 42 that after years of very high growth rates in China this trend has changed in the past three years. Compared to the years before, the Chinese market began to experience low growth rates in 2012 and 2013 and continued to shrink significantly in 2014 and 2015.

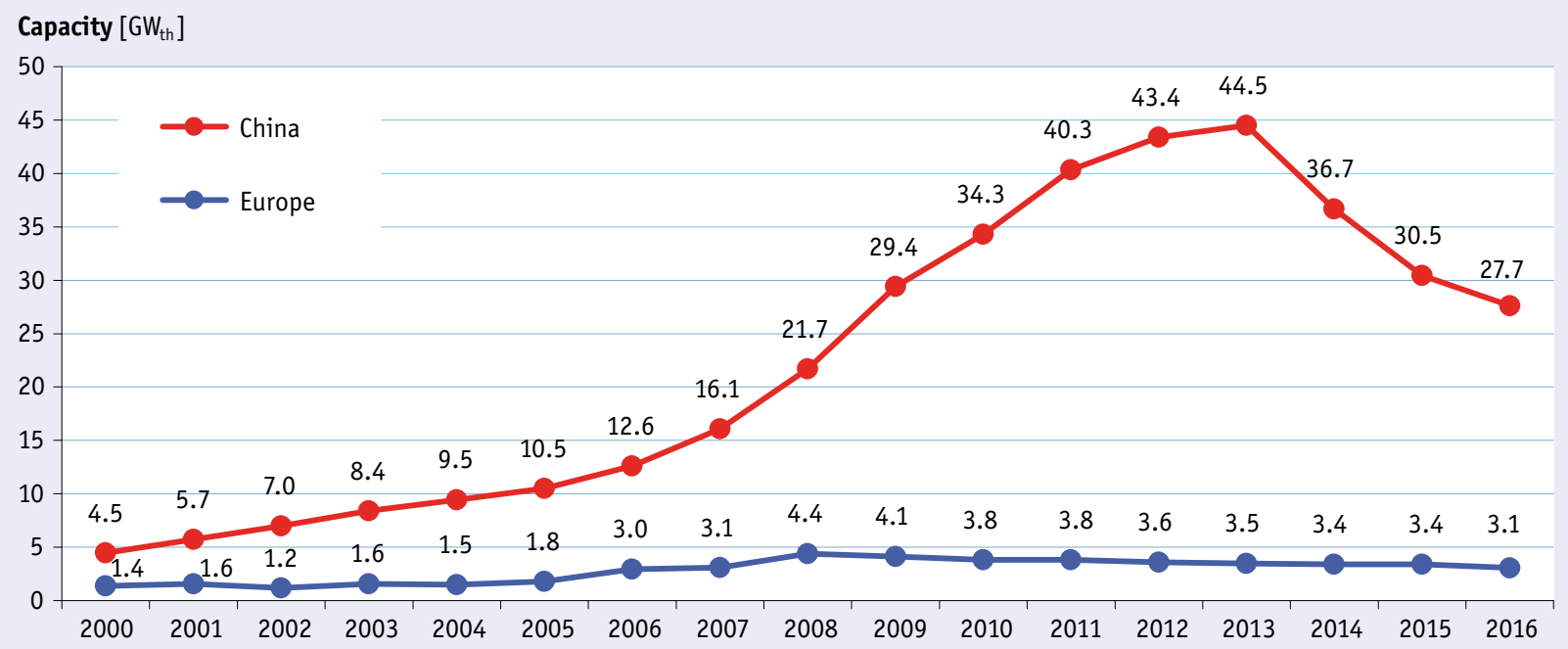

Figure 42: $\quad$ Market development of glazed water collectors in China and Europe 2000 - 2016 
The European market peaked at 4.4 GW th installed capacity in 2008 and has decreased steadily down to $3.4 \mathrm{GW}_{\text {th }}$ in 2015 and $3.1 \mathrm{GW}_{\text {th }}$ in 2016. In the remaining markets worldwide (RoW) an upward trend could be observed between 2002 and 2012 and a falling trend since 2013 (Figure 43).

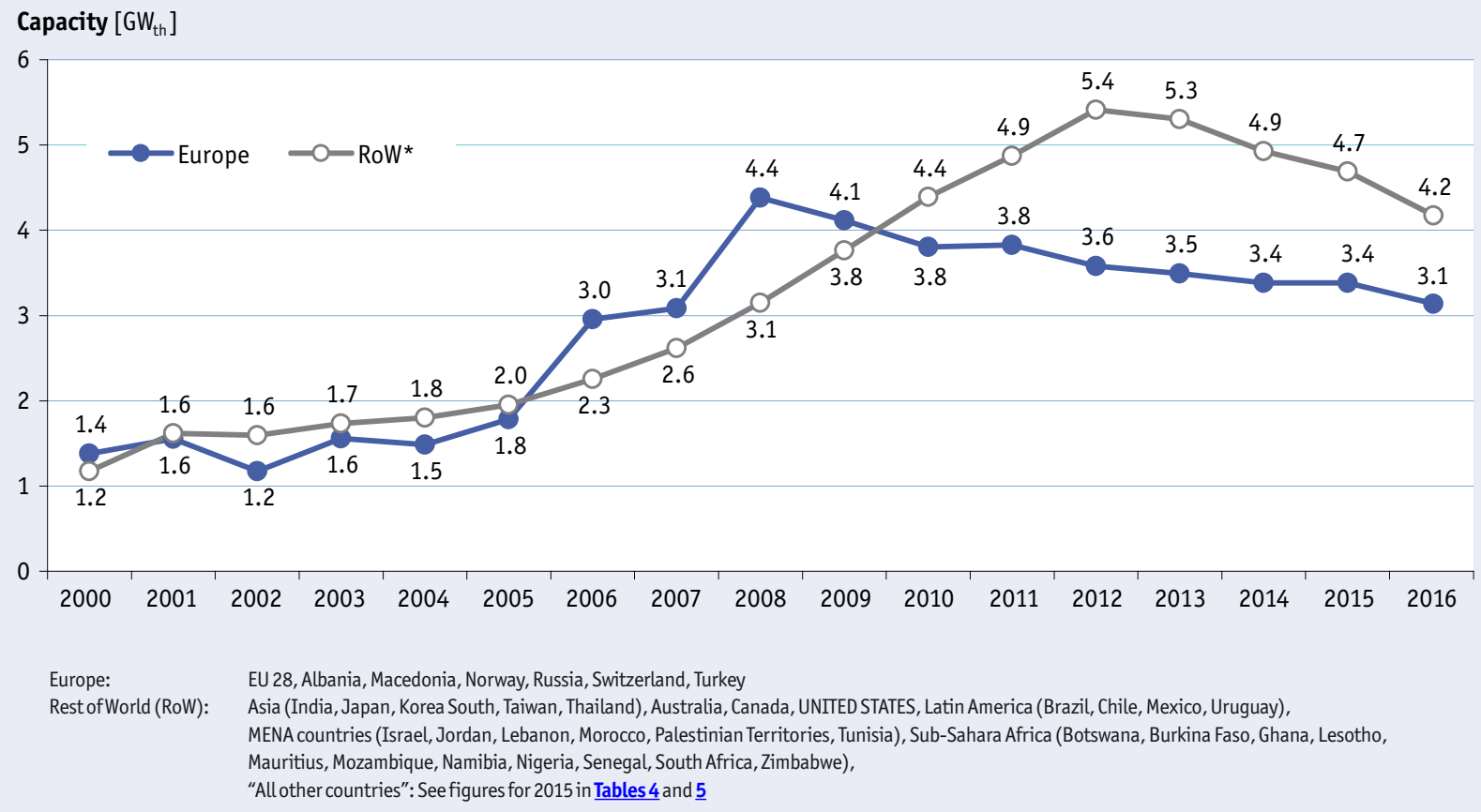

Figure 43: $\quad$ Market development of glazed water collectors in Europe and the rest of the world (RoW, excluding China) from 2000 to 2016

RoW includes all economic regions other than China and Europe. Of these regions, besides "all other countries", Asia (excluding China), Latin America, and the MENA countries hold the largest market shares (see Figure 44).

"Asia excl. China" is mainly influenced by the large Indian market, which dropped in 2013 but recovered significantly in 2014 and 2015. Other markets covered within this economic region (Japan, South Korea and Thailand) reported a market decreasein 2016.

Latin America shows the most steady and dynamic upward trend of all the economic regions. The dominant Brazilian, but also the large Mexican market as well as the evolving markets, for example in Chile, are responsible for the positive growth rates that have lasted 6 years in a row. Since 2015 the market in the region is about stable.

Glazed water collector markets in the MENA countries were characterized by steady growth from 2000 to 2013 . The market decline since 2014, which is shown in Figure 44, is explained by the fact that from 2015 on no data were received from two major markets namely Morocco and Jordan. The sales numbers in the most important market, Israel, slightly decreased in 2016.

The market volume for glazed water collectors in Australia was similar to the volume in Latin America and the MENA countries in 2009 and continued to shrink more or less through 2015. In 2016, a decrease of $-7 \%$ was reported.

Sub-Sahara African markets showed a decrease of $7 \%$ in 2016. Also in the United States and Canada the decreasing trend continued for the third year in a row but slowed down to $-3 \%$ in 2016. 


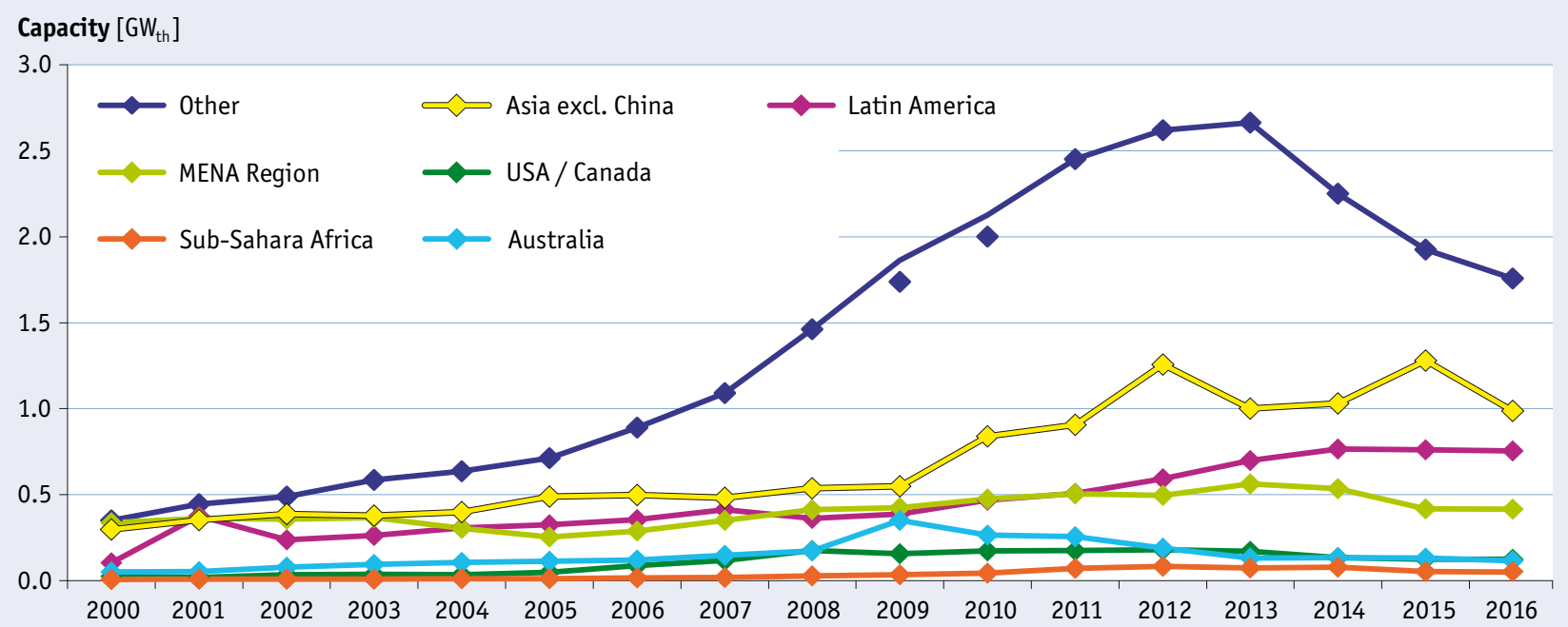

Figure 44: $\quad$ Market development of glazed water collectors in Rest of World (excluding China and Europe) from 2000 to 2016

In relative figures, the annual global market volume for glazed water collectors grew from $1.2 \mathrm{~kW}$ th per 1,000 inhabitants in 2000 to $7.5 \mathrm{~kW}_{\text {th }}$ per 1,000 inhabitants in 2013 and dropped down to $4.8 \mathrm{~kW}_{\text {th }}$ per 1,000 inhabitants in 2016 (Figure 45).

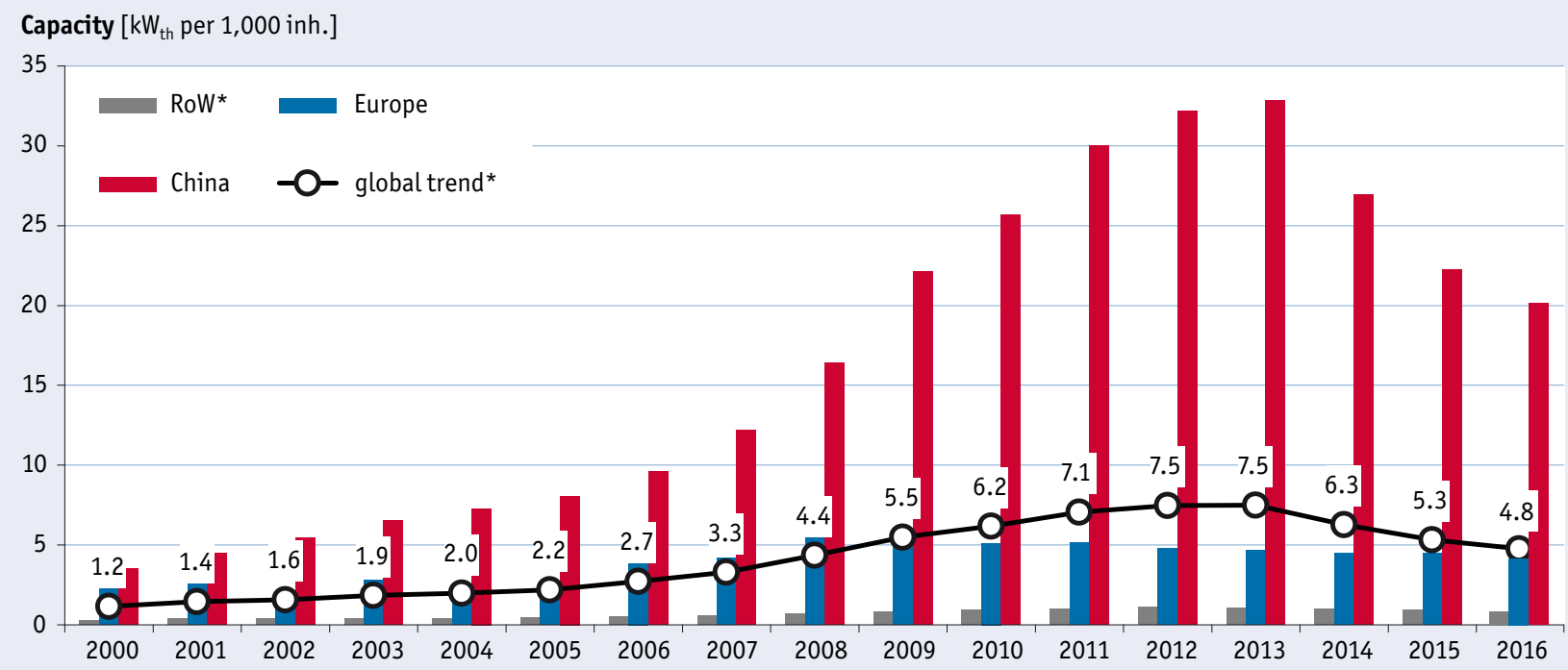

Figure 45: $\quad$ Annual installed capacity of glazed water collectors in $\mathrm{kW}$ th per 1,000 inhabitants from 2000 to 2016

The fact thatChina suffered major market declines from 2014 to 2016 is also reflected in the market penetration of glazed water collector installations per capita. The annually installed capacity rose from $3.5 \mathrm{~kW}_{\text {th }}$ per 1,000 inhabitants in 2000 and peaked at $32.8 \mathrm{~kW}_{\text {th }}$ per 1,000 inhabitants in 2013 and fell down to $20.1 \mathrm{~kW}_{\text {th }}$ per 1,000 inhabitants in 2016.

In Europe, market penetration peaked in 2008 with $5.9 \mathrm{~kW}$ th per 1,000 inhabitants. The downward trend between 2009 and 2013 seems to have stabilized from 2014 on and lies at $4.2 \mathrm{~kW}$ th per 1,000 inhabitants in 2016. 
With a newly installed capacity of $1.5 \mathrm{GW}_{\text {th }}$ in 2016 , unglazed water collectors accounted for $4 \%$ of the total installed solar thermal capacity (Figure 33). Compared to the year 2015 the market decreased by $-6.5 \%$.

The most important markets for unglazed water collectors in 2016 were the United States ( 577 MW $\left(266 \mathrm{MW}_{\text {th }}\right)$, Mexico $\left(75.8 \mathrm{MW}_{\text {th }}\right)$ and South Africa $\left(47.2 \mathrm{MW}_{\text {th }}\right)$, which accounted for $91 \%$ of the recorded unglazed water collector installations worldwide. Another $4 \%$ were installed in the Czech Republic (21 MW $\left.\mathrm{th}_{\mathrm{th}}\right)$, Canada (15 $\left.\mathrm{MW}_{\mathrm{th}}\right)$ and Germany (15 $\left.\mathrm{MW}_{\mathrm{th}}\right)$.

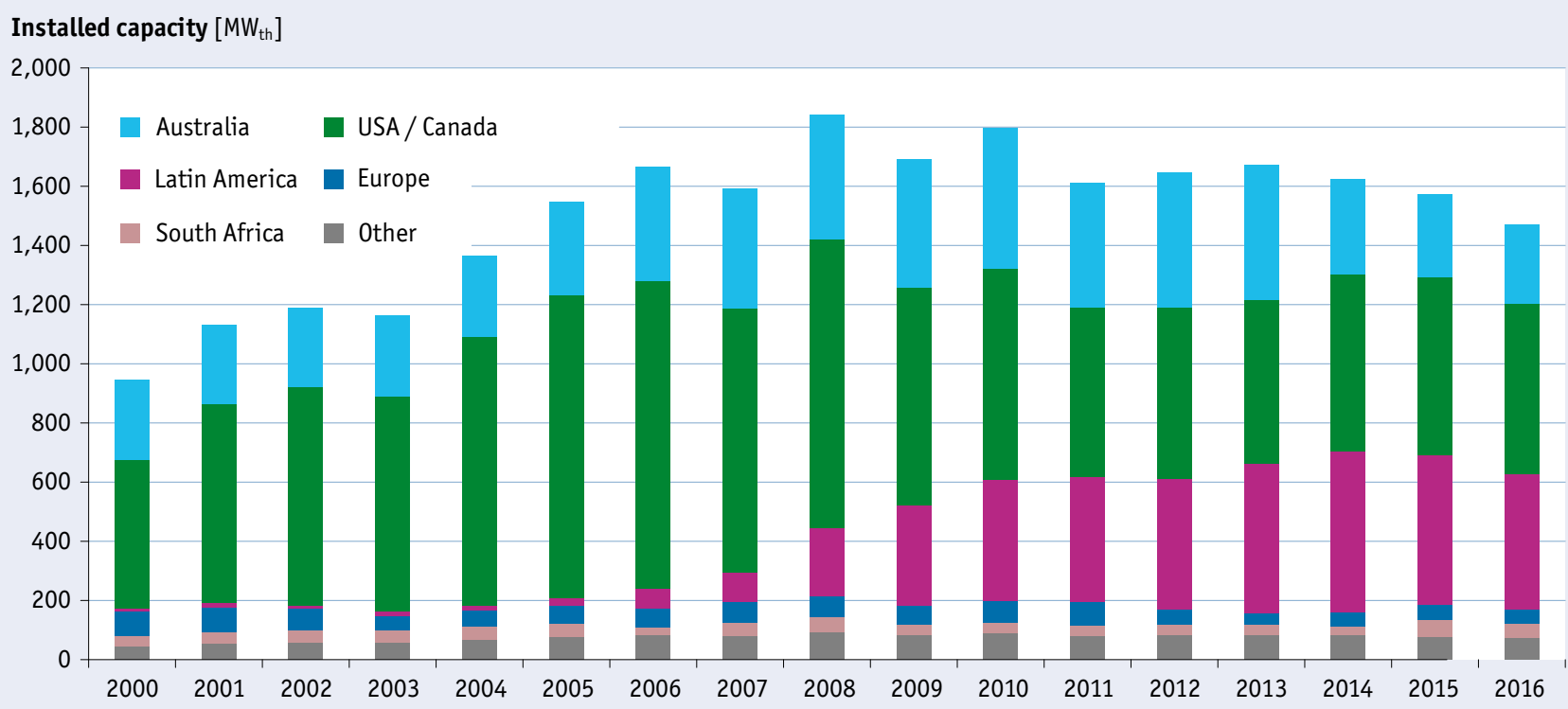

Figure 46: $\quad$ Global market development of unglazed water collectors from 2000 to 2016

The unglazed water collector market in the United States peaked in $2006\left(1.01 \mathrm{GW}_{\text {th }}\right)$ and has almost halved sincethen $\left(0.56 \mathrm{GW}_{\mathrm{th}}\right.$ in 2016). Nevertheless, the annual global market volume for unglazed water collectors has remained at a nearly constant level because of the Brazilian market, which entered in 2007 and peaked in 2014 with $0.45 \mathrm{GW}_{\mathrm{th}}$. Australia has faced a market decrease since 2010 and is now the third largest market for unglazed water collectors behind that of the United States and Brazil. 
In this section, the contribution of the total installed glazed and unglazed water collectors in operation to the thermal energy supply and $\mathrm{CO}_{2}$ reduction is shown.

The basis for these calculations is the total glazed and unglazed water collector area in operation in each country as shown in Table 3. The contribution of the total installed air collector capacity in operation in 2016 of $1.2 \mathrm{GW}_{\text {th }}$ was not taken into consideration with a share of around $0.3 \%$ of the total installed collector capacity these collectors were omitted from the calculation.

The results are based on calculations using the simulation tool T-SOL expert 4.5 for each country. For the simulations, different types of collectors and applications as well as the characteristic climatic conditions were considered for each country. A more detailed description of the methodology can be found in the appendix (see Chapter 9).

The annual collector yield of all water-based solar thermal systems in operation by the end of 2016 in the 66 recorded countries was $375 \mathrm{TWh}(=1,350 \mathrm{PJ})$. This corresponds to a final energy savings equivalent of 40.3 million tons of oil and 130 million tons of $\mathrm{CO}_{2}$. The calculated number of different types of solar thermal systems in operation was around 113 million (Table 7).

The most important application for solar thermal systems is domestic hot water heating (see section 7.3), and therefore, this type of application ccounted for the highest savings in terms of oil equivalent and $\mathrm{CO}_{2}$. In $2016,94 \%$ of the energy provided by solar thermal systems worldwide was used for heating domestic hot water, mainly by small-scale systems in single-family houses (67\%) and larger applications attached to multi-family houses, hotels, schools, etc. (27\%). Swimming pool heating held a share of $4 \%$ in the contribution to the energy supply and $\mathrm{CO}_{2}$ reduction and the remaining $1 \%$ was met by solar combi-systems.

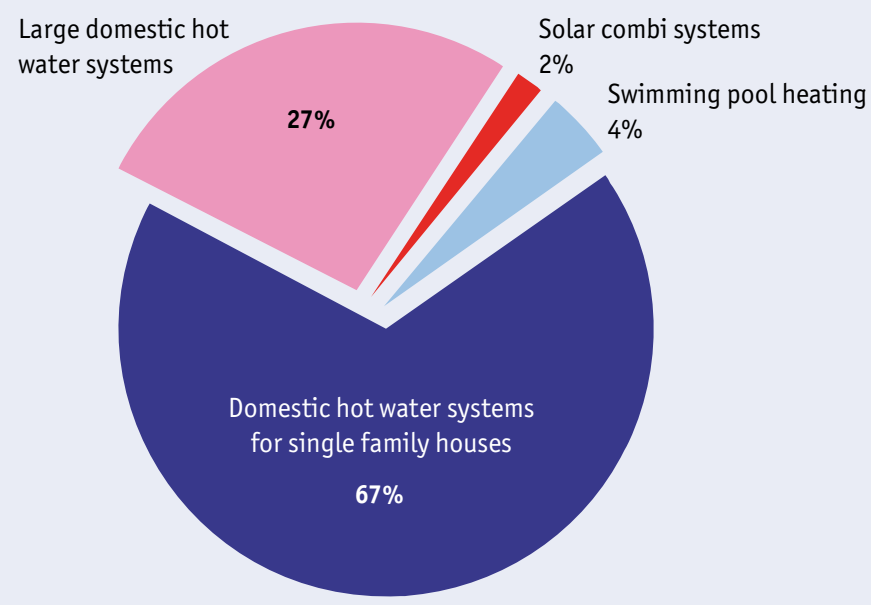

Figure 47: $\quad$ Share of energy savings and $\mathrm{CO}_{2}$ reduction by type of application of glazed and unglazed water collectors in operation in 2016 
Table 7 summarizes the calculated annual collector yields and the corresponding oil equivalents and $\mathrm{CO}_{2}$ reductions of all waterbased solar thermal systems (systems for hot water, space heating and swimming pool heating) in operation by the end of 2016.

\begin{tabular}{|c|c|c|c|c|c|c|}
\hline Country & $\begin{array}{c}\text { Total } \\
\text { collector area }\left[\mathrm{m}^{2}\right]\end{array}$ & $\begin{array}{c}\text { Total } \\
\text { capacity } \\
{\left[\mathrm{MW}_{\text {th }}\right]}\end{array}$ & $\begin{array}{c}\text { Calculated num- } \\
\text { ber } \\
\text { of systems }\end{array}$ & $\begin{array}{c}\text { Collector yield } \\
\text { [GWh/a] }\end{array}$ & $\begin{array}{c}\text { Energy savings } \\
{\left[\mathrm{t}_{\mathrm{oe}} / \mathrm{a}\right]}\end{array}$ & $\begin{array}{c}\mathrm{CO}_{2} \text { reduction } \\
{\left[\mathrm{t}_{\mathrm{coze}} / \mathrm{a}\right]}\end{array}$ \\
\hline Albania & 207,258 & 145 & 43,110 & 146 & 15,714 & 50,725 \\
\hline Australia & $8,830,000$ & 6,181 & $1,121,309$ & 5,484 & 589,469 & $1,902,806$ \\
\hline Barbados & 214,290 & 150 & 53,573 & 189 & 20,325 & 65,610 \\
\hline Belgium & 628,333 & 440 & 109,347 & 250 & 26,847 & 86,661 \\
\hline Botswana**** & 9,500 & 7 & 1,552 & 9 & 957 & 3,089 \\
\hline Burkina Faso ** & 1,071 & 1 & 68 & 1 & 107 & 346 \\
\hline Canada & 925,465 & 648 & 35,295 & 445 & 47,871 & 154,529 \\
\hline Chile & 291,550 & 204 & 60,495 & 202 & 21,659 & 69,914 \\
\hline China & $463,579,999$ & 324,506 & $78,576,810$ & 259,854 & $27,929,294$ & $90,155,760$ \\
\hline Croatia & 210,092 & 147 & 36,562 & 106 & 11,350 & 36,636 \\
\hline Cyprus & 687,133 & 481 & 300,338 & 611 & 65,644 & 211,900 \\
\hline France (mainland)+ & $2,218,807$ & 1,553 & 485,271 & 1,075 & 115,552 & 373,002 \\
\hline Germany & $19,336,110$ & 13,535 & $2,270,801$ & 7,873 & 846,218 & $2,731,591$ \\
\hline Ghana* & 2,274 & 2 & 119 & 2 & 220 & 711 \\
\hline Greece & $4,497,600$ & 3,148 & $1,200,724$ & 3,133 & 336,719 & $1,086,930$ \\
\hline Hungary & 298,100 & 209 & 44,624 & 135 & 14,489 & 46,771 \\
\hline India++ & $9,533,411$ & 6,673 & $4,198,753$ & 8,232 & 884,789 & $2,856,099$ \\
\hline Ireland & 343,251 & 240 & 79,440 & 144 & 15,447 & 49,861 \\
\hline Israel & $4,634,434$ & 3,244 & $1,483,946$ & 4,276 & 459,574 & $1,483,505$ \\
\hline Italy & $4,409,369$ & 3,087 & 767,349 & 2,690 & 289,108 & 933,240 \\
\hline Japan & $3,503,560$ & 2,452 & 851,427 & 2,030 & 218,212 & 704,390 \\
\hline Jordan* & $1,260,506$ & 882 & 223,109 & 1,194 & 128,286 & 414,108 \\
\hline Korea, South & $1,851,618$ & 1,296 & 424,205 & 961 & 103,270 & 333,356 \\
\hline Latvia & 12,332 & 9 & 2,146 & 5 & 562 & 1,814 \\
\hline Morocco* & 451,000 & 316 & 60,900 & 383 & 41,146 & 132,821 \\
\hline Mozambique & 1,386 & 1 & 347 & 1 & 127 & 408 \\
\hline Namibia & 37,898 & 27 & 4,680 & 35 & 3,716 & 11,994 \\
\hline Netherlands & 652,205 & 457 & 155,233 & 260 & 27,978 & 90,312 \\
\hline New Zealand ${ }^{* * *}$ & 159,645 & 112 & 32,703 & 99 & 10,592 & 34,191 \\
\hline Nigeria & 355 & 0 & 136 & 0 & 33 & 108 \\
\hline Norway** & 50,506 & 35 & 2,517 & 19 & 1,998 & 6,450 \\
\hline Palestine $* * * *$ & $1,834,850$ & 1,284 & 630,026 & 1,712 & 183,973 & 593,865 \\
\hline Poland & $2,137,200$ & 1,496 & 268,931 & 873 & 93,802 & 302,794 \\
\hline Portugal & $1,020,132$ & 714 & 184,924 & 788 & 84,651 & 273,253 \\
\hline Romania & 174,490 & 122 & 30,366 & 96 & 10,357 & 33,432 \\
\hline Russia & 23,591 & 17 & 1,264 & 10 & 1,053 & 3,398 \\
\hline Senegal $* * * *$ & 1,734 & 1 & 432 & 2 & 182 & 587 \\
\hline Slovakia & 161,100 & 113 & 19,717 & 75 & 8,084 & 26,094 \\
\hline Slovenia & 146,800 & 103 & 22,849 & 62 & 6,642 & 21,442 \\
\hline South Africa & $1,908,419$ & 1,336 & 433,952 & 1,363 & 146,480 & 472,837 \\
\hline Spain & $3,903,788$ & 2,733 & 459,281 & 2,722 & 292,597 & 944,503 \\
\hline Sweden & 544,154 & 381 & 41,315 & 199 & 21,376 & 69,001 \\
\hline Switzerland & $1,620,150$ & 1,134 & 196,023 & 640 & 68,763 & 221,966 \\
\hline Taiwan & $1,689,148$ & 1,182 & 333,501 & 1,028 & 110,468 & 356,589 \\
\hline Thailand $* * * *$ & 157,536 & 110 & 36,001 & 132 & 14,212 & 45,875 \\
\hline Tunisia & 906,896 & 635 & 274,560 & 818 & 87,909 & 283,769 \\
\hline Turkey & $21,332,636$ & 14,933 & $4,927,839$ & 19,137 & $2,056,893$ & $6,639,650$ \\
\hline United Kingdom & 798,169 & 559 & 138,903 & 310 & 33,333 & 107,598 \\
\hline United States & $25,092,885$ & 17,565 & 421,560 & 11,159 & $1,199,340$ & $3,871,470$ \\
\hline
\end{tabular}

Table 7: $\quad$ Calculated annual collector yield and corresponding oil equivalent and $\mathrm{CO}_{2}$ reduction of glazed and unglazed water collectors in operation by the end of 2016 
In Chapters 6.1 to 6.3, the annual collectoryield, energy savings and $\mathrm{CO}_{2}$ savings by economic regions and worldwide are graphed.

\subsection{Annual collector yield by economic region}

In 2016, gross solar thermal collector yields amounted to 375 TWh worldwide (Table 7) and the major share, $65 \%$, was contributed by domestic hot water applications for single-family houses (Figure 47).

China accounted for $69 \%$ of the thermal energy gains (259.9 TWh), Europe for $12 \%$ (44.7 TWh) and the Rest of the World for $19 \%$ (70.6 TWh) (Figure 48).

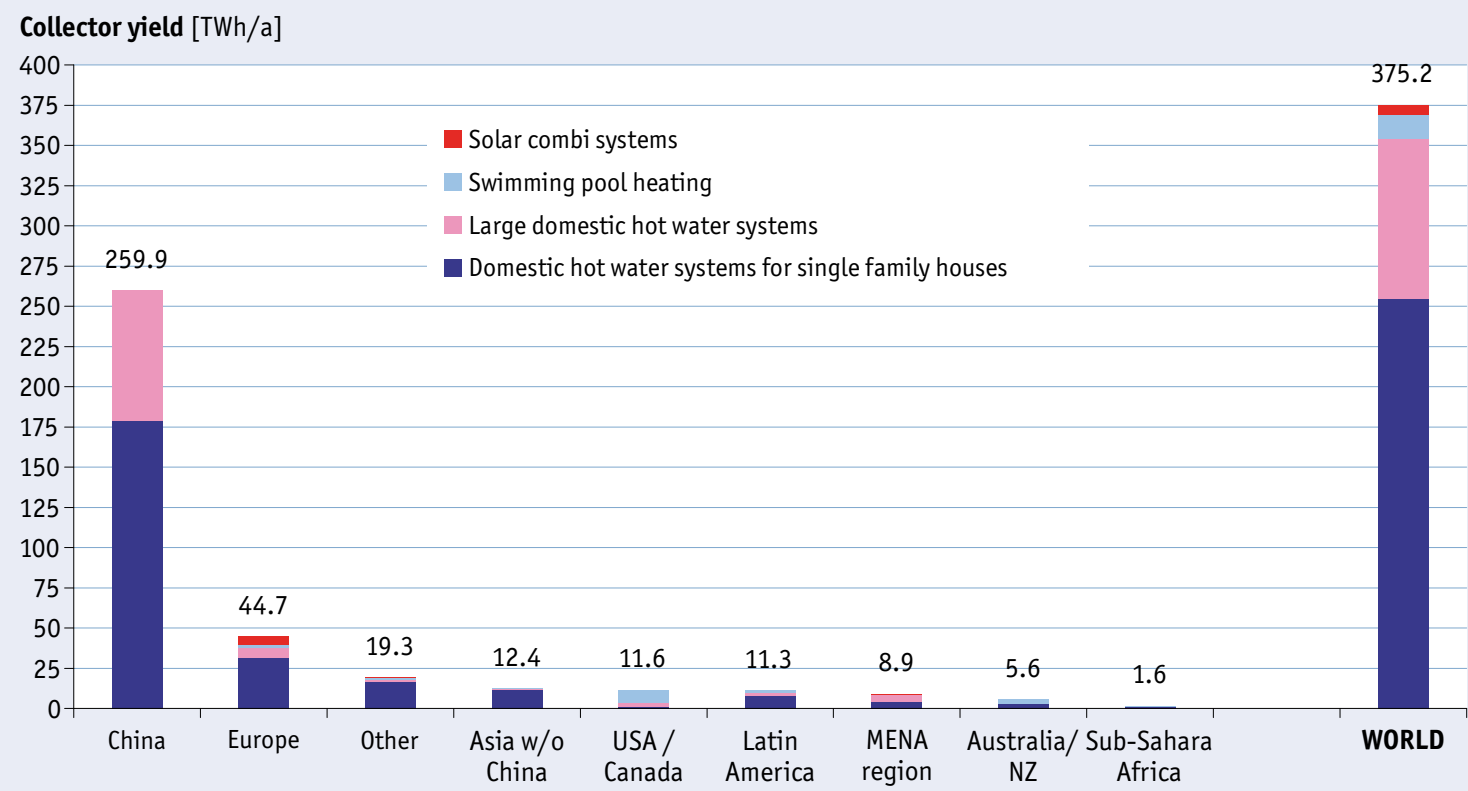

Sub-Sahara Africa: Asiaw/o China:

Latin America:

Europe:

MENA countries:
Botswana, Burkina Faso, Ghana, Lesotho, Mauritius, Mozambique, Namibia, Senegal, South Africa, Zimbabwe India, Japan, South Korea, Taiwan Thailand

Barbados, Brazil, Chile, Mexico, Uruguay

EU 28, Albania, Macedonia, Norway, Russia, Switzerland, Turkey

Israel, Jordan, Lebanon, Morocco, Palestine, Tunisia

Figure 48: $\quad$ Annual collector yield of unglazed and glazed water collectors in operation in 2016 
Considering a utilization ratio of 0.8 for the reference oil boiler, which is assumed to be partially replaced by the solar thermal system (see methodology Chapter 9.1), the annual final energy savings amounted to 469 TWh or 40.3 million tons of oil equivalent in $2016^{24}$.

The breakdown shows that China accounted for 27.9 million tons oil equivalent, Europe for 4.8 million tons oil equivalent, and the Rest of World for 7.6 million tons oil equivalent (Figure 49).

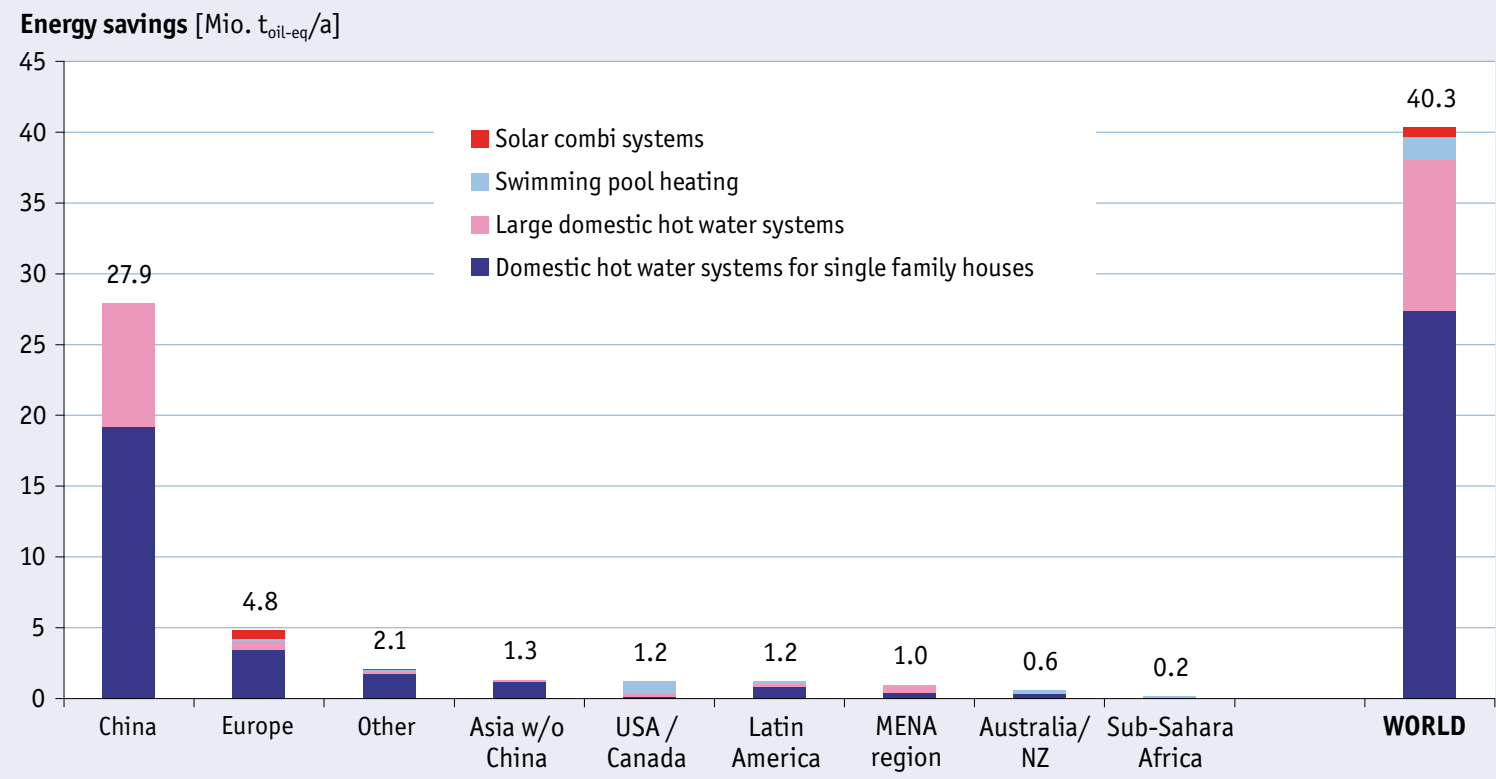

Sub-Sahara Africa: Asiaw/o China:

Botswana, Burkina Faso, Ghana, Lesotho, Mauritius, Mozambique, Namibia, Senegal, South Africa, Zimbabwe

Latin America: India, Japan, South Korea, Taiwan Thailand

Europe:

Barbados, Brazil, Chile, Mexico, Uruguay

EU 28, Albania, Macedonia, Norway, Russia, Switzerland, Turkey

MENA countries:

Israel, Jordan, Lebanon, Morocco, Palestine, Tunisia

Figure 49: $\quad$ Annual energy savings in oil equivalent by unglazed and glazed water collectors in operation in 2016 
The use of solar thermal energy varies greatly from region to region and can be roughly distinguished by the type of solar thermal collector used (unglazed water collectors, evacuated tube collectors, flat plate collectors, glazed and unglazed air collectors, concentrating collectors), the type of system operation (pumped solar thermal systems, thermosiphon systems), and the main type of application (swimming pool heating, domestic hot water preparation, space heating, others such as heating of industrial processes, solar district heating or solar thermal cooling).

In Chapters 7.1 to 7.3, the share of these system types and applications are shown by different economic regions for both the cumulated capacity in operation in 2016 and the newly installed capacity in $2016^{26}$.

\subsection{Distribution by type of solar thermal collector}

In terms of the total water collector area worldwide, evacuated tube collectors dominated with a share of $72 \%$ of the cumulated capacity in operation (Figure 51) and a share of $74 \%$ of the newly installed capacity (Figure 52). Worldwide flat plate collectors accounted for $22 \%$ of the cumulated capacity in operation (Figure 51) and a $22 \%$ share of the newly installed capacity (Figure 52 ). Unglazed water collectors accounted for $6 \%$ of the cumulated water collectors installed worldwide and for $4 \%$ of the newly installed capacity.

In all economic regions besides China (evacuated tube collectors) and North America (unglazed water collectors) flat plate collectors are dominant.

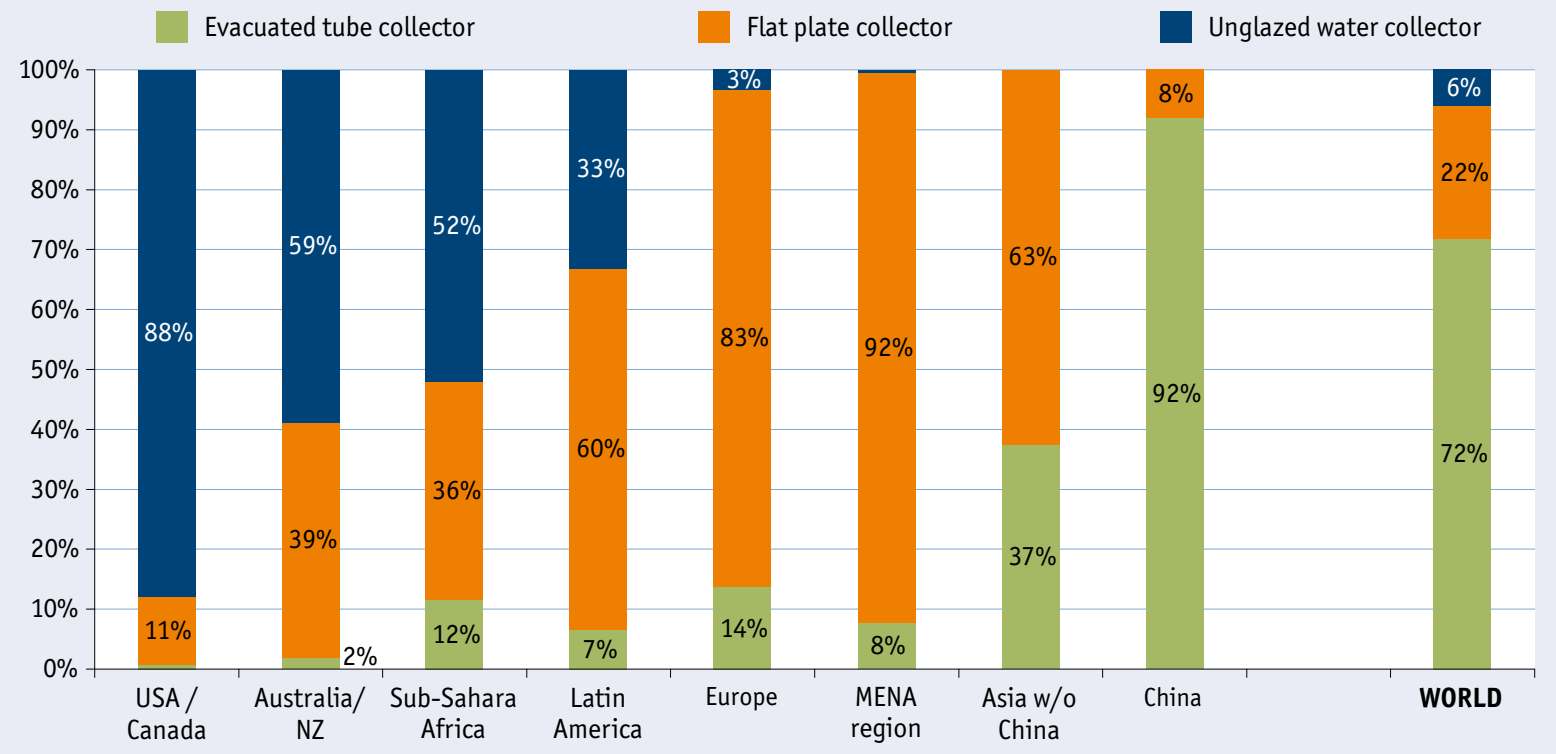

Sub-Sahara Africa: $\quad$ Botswana, Burkina Faso, Ghana, Lesotho, Mauritius, Mozambique, Namibia, Senegal, South Africa, Zimbabwe

Asiaw/o China: $\quad$ India, Japan, South Korea, Taiwan Thailand

Latin America: $\quad$ Barbados, Brazil, Chile, Mexico, Uruguay

Europe: $\quad$ EU 28, Albania, Macedonia, Norway, Russia, Switzerland, Turkey

MENA countries: $\quad$ Israel, Jordan, Lebanon, Morocco, Palestine, Tunisia

Figure 51: Distribution by type of solar thermal collector for the total installed water collector capacity in operation by the end of 2016

26 It has to be considered that statistical information summarized in Chapters 5.1 to 5.4 is sometimes based on rough expert estimations by country representatives only and hence especially the share by type of system and application of the cumulated installed capacity in operation may deviate from figures published in previous editions of this report. 


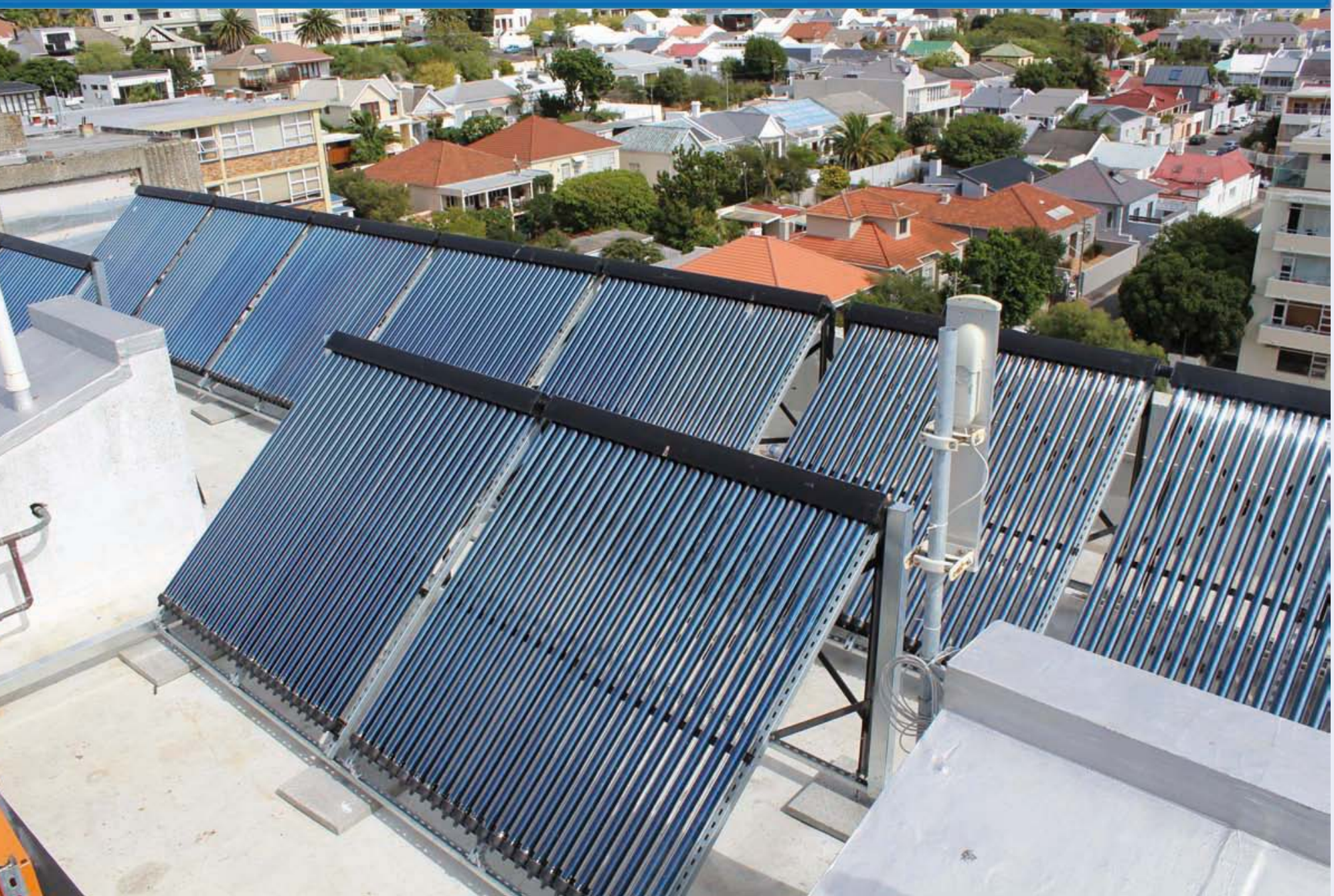

$85 m^{2}$ evacuated tubes at Centurion Building, CapeTown

Photo: SOLTRAIN/AEE INTEC

Evacuated tube collector

Flat plate collector

Unglazed water collector

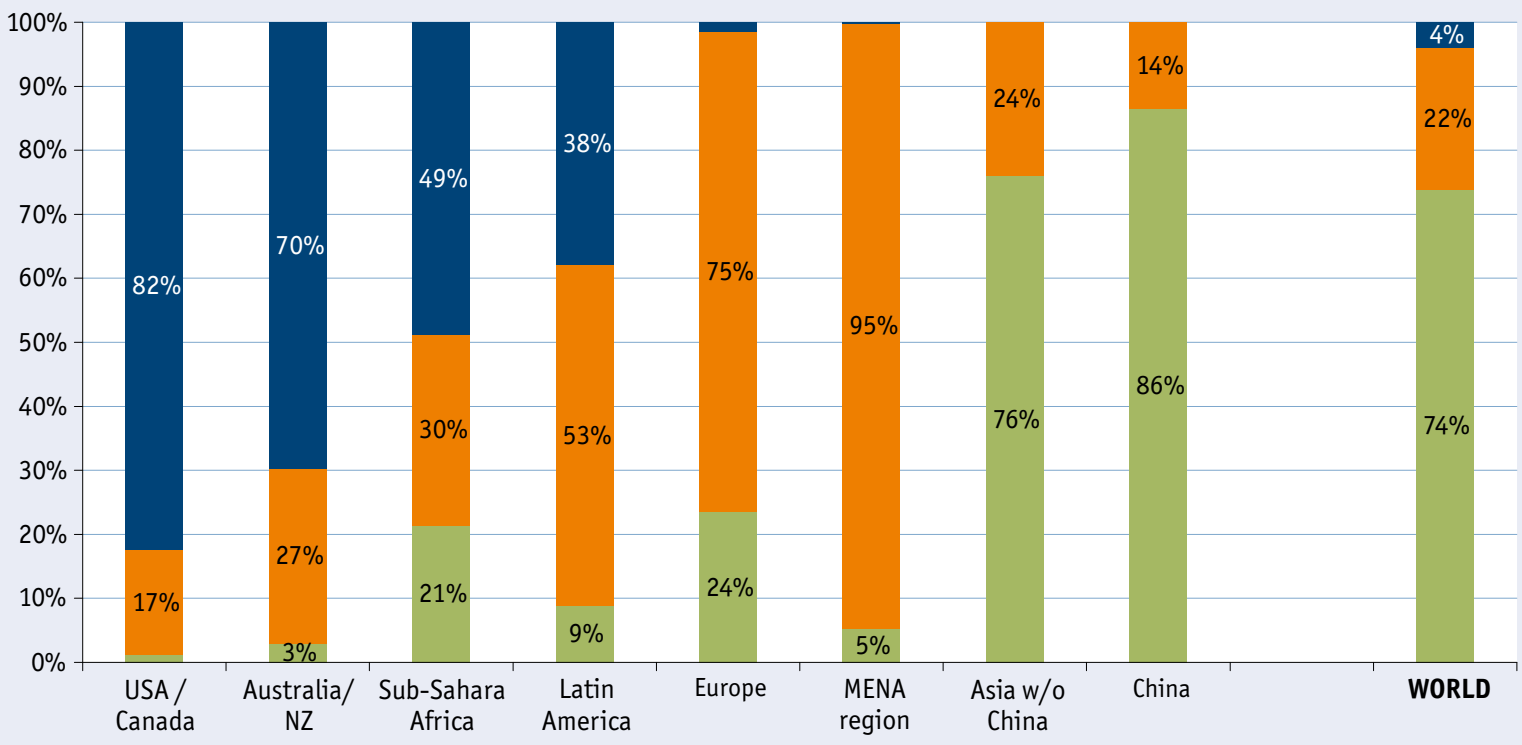

Sub-Sahara Africa:

Asiaw/o China:

Latin America:

Europe:

MENA countries:
Botswana, Lesotho, Mauritius, Mozambique, Namibia, Senegal, South Africa, Zimbabwe India, Japan, South Korea, Taiwan Thailand

Brazil, Chile, Mexico, Uruguay

EU 28, Albania, Macedonia, Norway, Russia, Switzerland, Turkey

Israel, Jordan, Lebanon, Morocco, Palestine, Tunisia

Figure 52: $\quad$ Distribution by type of solar thermal collector for the newly installed water collector capacity in 2016 
Worldwide, morethan three quarters of all solar thermal systems installed are thermosiphon systems and the restare pumped solar heating systems (Figure 53). Similar to the distribution by type of solar thermal collector in total numbers, the Chinese market influenced the overall figures the most. In 2016, $89 \%$ of the newly installed systems were estimated to be thermosiphon systems while pumped systems only accounted for $11 \%$ (Figure 54 ).

In general, thermosiphon systems are more common in warm climates such as in Africa, South America, southern Europe and the MENA countries. In these regions thermosiphon systems are more often equipped with flat plate collectors, while in China the typical thermosiphon system for domestic hot water preparation is equipped with evacuated tubes.

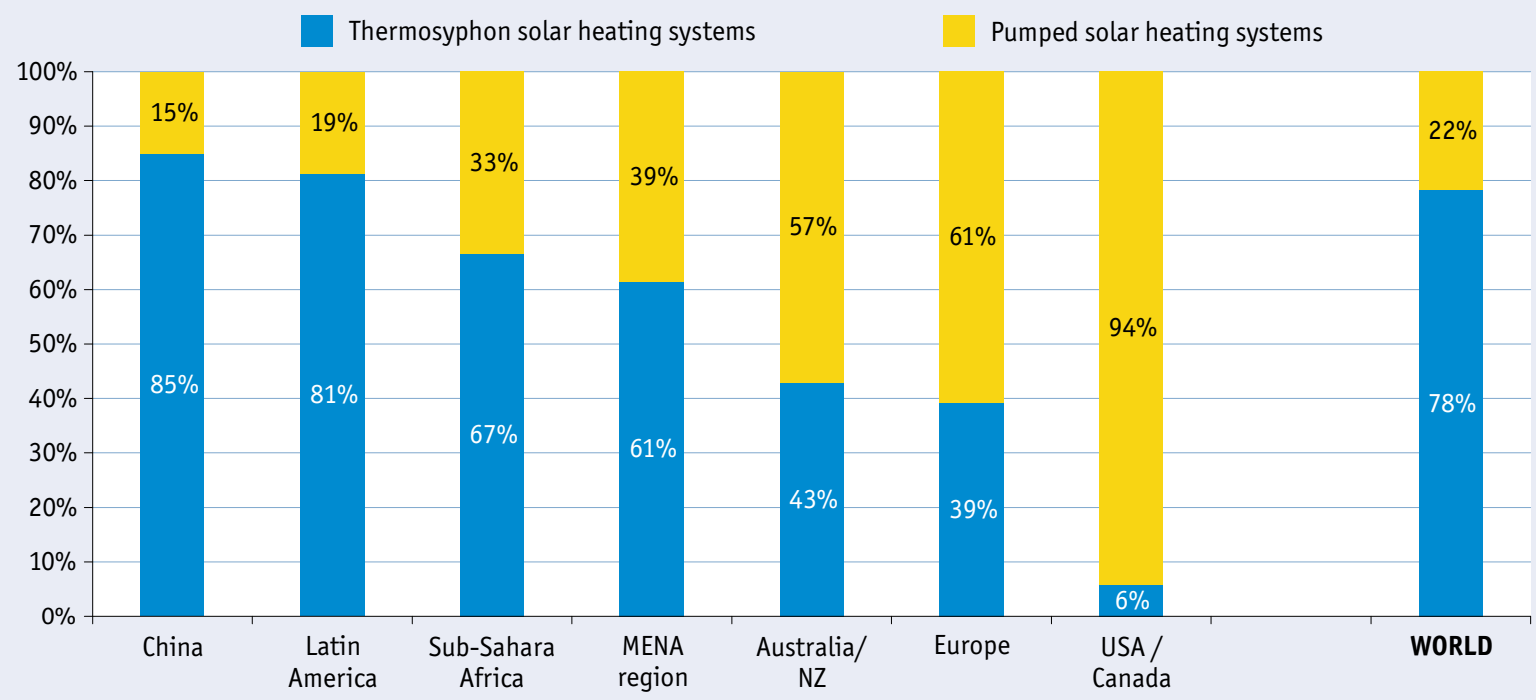

Figure 53: Distribution by type of system for the total installed glazed water collector capacity in operation by the end of 2016

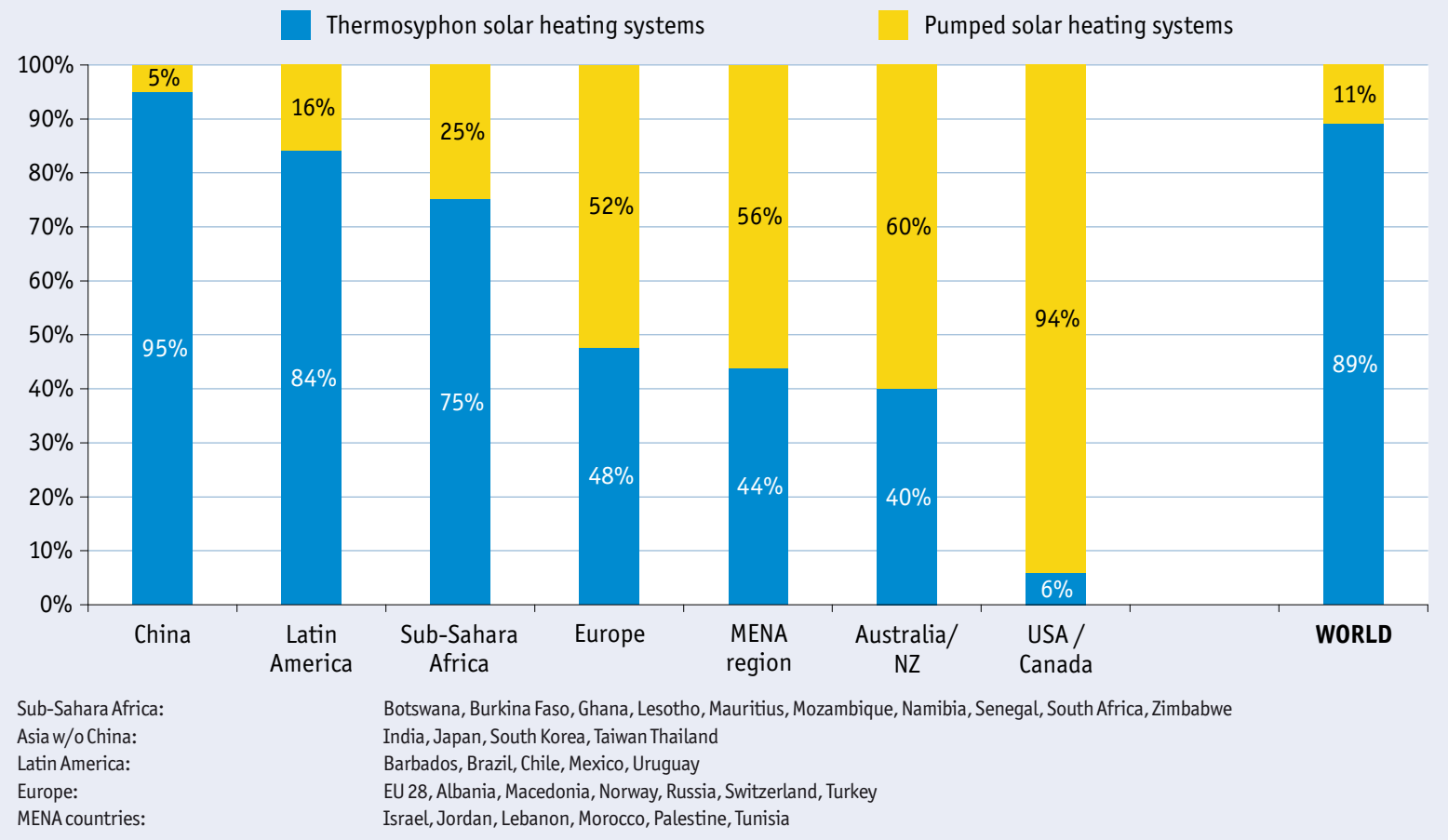

Figure 54: Distribution by type of system for the newly installed glazed water collector capacity in 2016 
By the end of 2016, 651 million square meters of water-based solar thermal collectors corresponding to a thermal peak capacity of $456 \mathrm{GW}_{\text {th }}$ were in operation worldwide (Table 3). Out of these, $6 \%$ were used for swimming pool heating, $63 \%$ were used for domestic hot water preparation in single-family houses and $28 \%$ were attached to larger domestic hot water systems for multifamily houses, hotels, hospitals, schools, etc. Around $2 \%$ of the worldwide installed capacity supplied heat for both domestic hot water and space heating (solar combi-systems). The remaining systems accounted for around $1 \%$ and delivered heat to other applications such as district heating networks, industrial processes or thermally driven solar cooling applications (Figure 55). Considering typical solar thermal system sizes for the mentioned applications in the different countries covered in this report the number of systems in operation worldwide is calculated to be around 113 million.

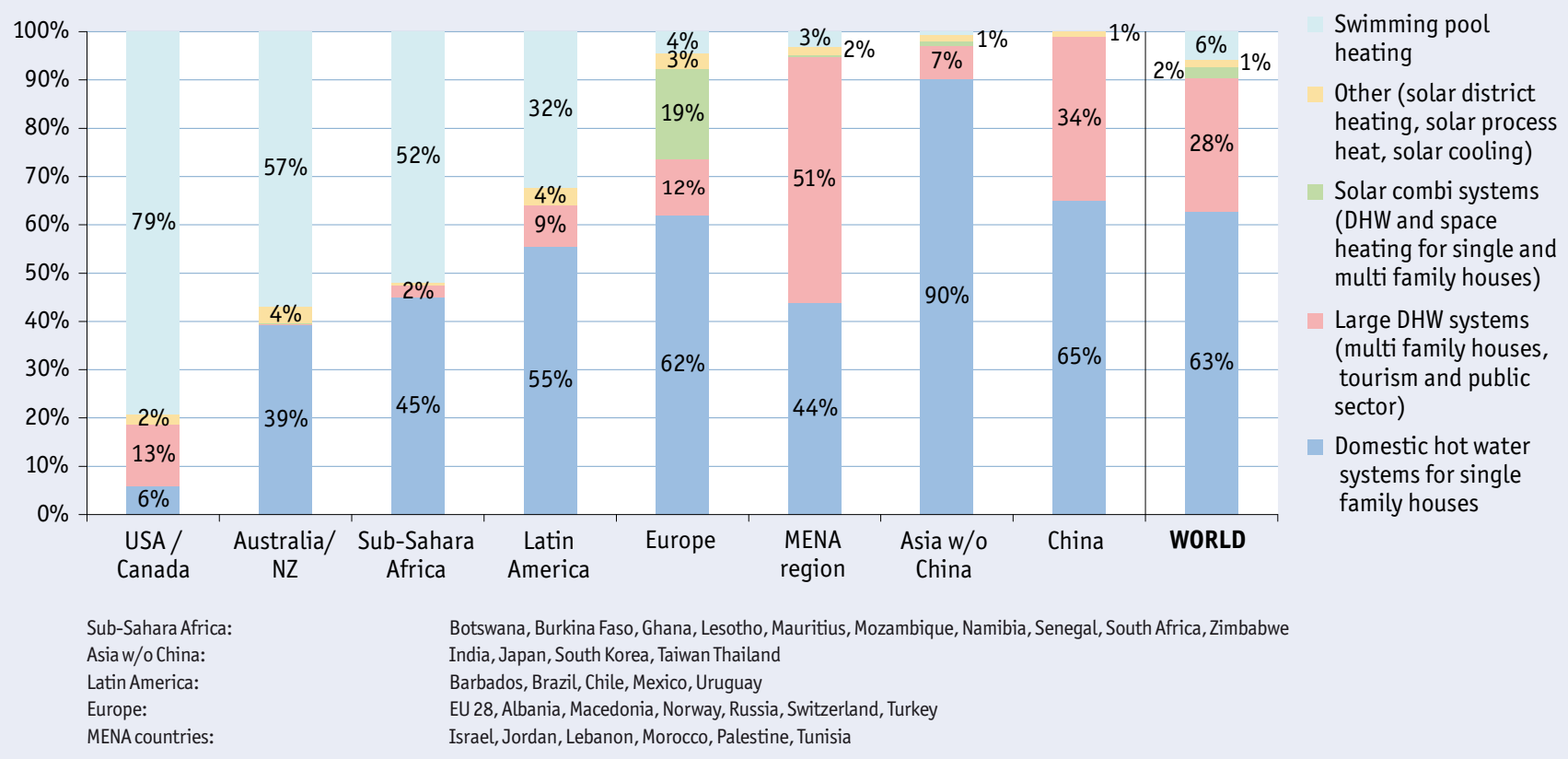

Figure 55: Distribution of solar thermal systems by application for the total installed water collector capacity by economic region in operation by the end of 2016

The newly installed water-based solar thermal collector area amounted to 52.1 million square meters, which corresponds to $36.4 \mathrm{GW}$ of thermal peak capacity (Table 5).

Compared to the cumulated installed capacity, the share of swimming pool heating was less for new installations ( $6 \%$ of total capacity and $3 \%$ of newly installed capacity). A similar trend can be seen for several years now for domestic hot water systems in single-family homes: $63 \%$ of total capacity in operation and $42 \%$ of new installations in 2016 make this kind of systems the most common application worldwide but with a decreasing tendency.

By contrast, the share of large-scale domestic hot water applications basically tends to increase ( $28 \%$ of total capacity and $50 \%$ of newly installed capacity). It can be assumed that this market segment took over some of the market shares from both swimming pool heating and domestic hot water systems in single-family homes. 


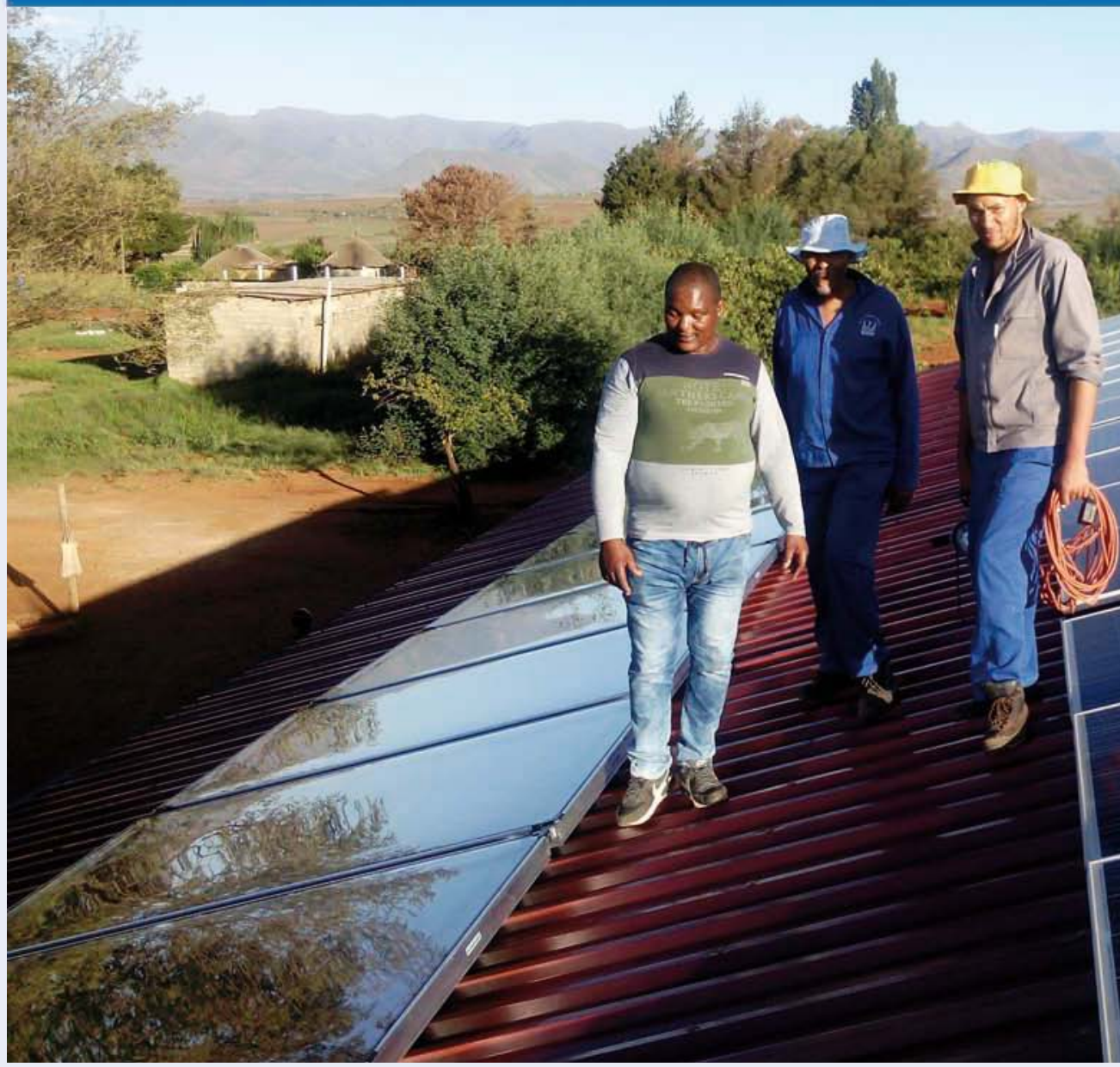

$30 \mathrm{~m}^{2}$ flat plate collectors at Pitseng Highschool, Lesotho

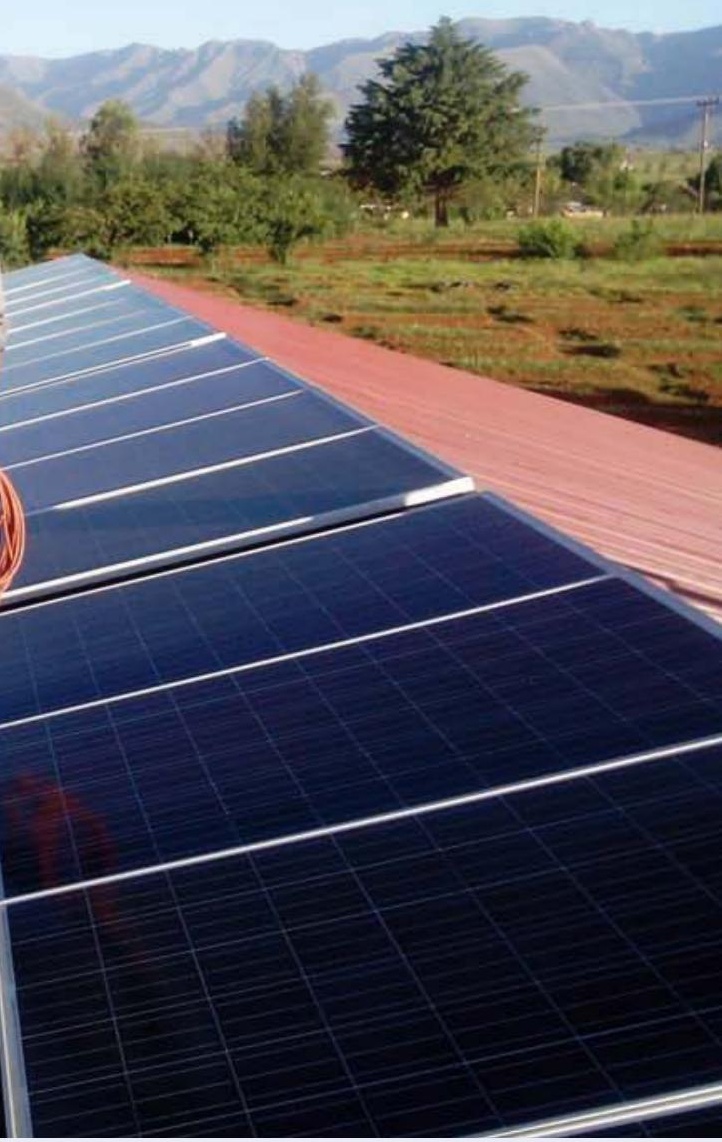

Photo:SOLTRAIN/AEE INTEC

The share of applications, such as solar district heating and solar process heat are increasing the share steadily even if it is still on a low level of $3 \%$ globally (Figure 56 ).

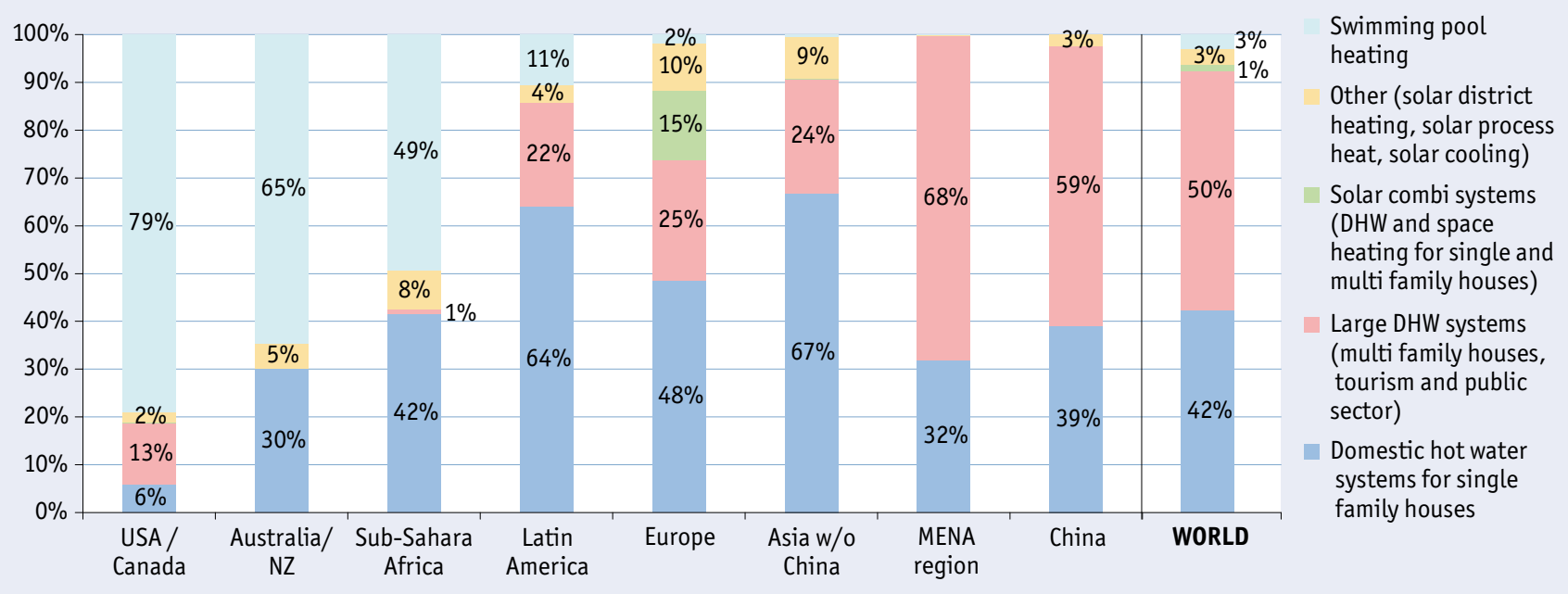

Sub-Sahara Africa: Asiaw/o China:

Latin America:

Europe:

MENA countries:
Botswana, Burkina Faso, Ghana, Lesotho, Mauritius, Mozambique, Namibia, Senegal, South Africa, Zimbabwe India, Japan, South Korea, Taiwan Thailand

Barbados, Brazil, Chile, Mexico, Uruguay

EU 28, Albania, Macedonia, Norway, Russia, Switzerland, Turkey

Israel, Jordan, Lebanon, Morocco, Palestine, Tunisia

Figure 56: Distribution of solar thermal systems by application for the newly installed water collector capacity by economic region in 2016 
In this chapter, economic performance indicators for major solar thermal markets worldwide are analyzed. In total, technical and economic benchmark figures for solar thermal systems from 12 countries (Australia, Austria, Brazil, Canada, China, Denmark, France, Germany, India, Israel, South Africa and Turkey) were collected from a comprehensive questionnaire. Solar thermal experts, solar trade associations, technology providers and installation companies from these countries were asked to provide cost information on solar thermal applications most commonly applied in their countries, including small domestic hot water systems for single-family homes (DHW-SFH), large domestic hot water systems for multi-family homes (DHW-MFH), small combined hot water and space heating systems (COMBI-SFH) and swimming pool heating systems with unglazed water collectors (POOL HEATING). Moreover, cost information on 12 Danish large-scale solar district heating systems (SDH) was collected. All cost figures and the related exchange rates to Euro refer to the year 2016.

In Chapters 8.1 to 8.4 the results are summarized in bar charts that show both the range of investment costs as well as the range of the corresponding Levelized Cost of Solar Thermal Generated Heat ( $L C O H)$ for each solar thermal application available in the respective country. Cost data are expressed as specific values in Euro per square meter gross collector area $\left[€ / \mathrm{m}^{2}\right.$ gross] and refer to end-user (customer) prices excluding value added tax and subsidies. The LCOH is expressed as $€$-cents ${ }^{27}$ per kWh thermal end energy provided by the solar thermal system. The methodology applied for the $\mathrm{LCOH}$ calculation as well as all relevant techno-economic benchmark figures and assumptions are documented in the appendix (Chapter 9.3).

\section{Summary of results}

The lowest $\mathrm{LCOH}$ for domestic applications were:

- $\sim 1 €$-ct/kWh for pool heating systems (Australia, Brazil)

- $2-4 €-c t / k W h$ for small thermosiphon domestic hot water systems (Brazil, India, Turkey) and $7-8 €-c t / k W h$ for small pumped domestic hot water systems (Australia, China)

- $2-3 €-c t / k W h$ for larger pumped systems in multi-family homes (Brazil and India)

- $3 €-\mathrm{ct} / \mathrm{kWh}$ for small combined hot water and space heating systems (Brazil)

The highest $\mathrm{LCOH}$ for domestic applications were:

- $\sim 2 €$-ct/kWh for pool heating systems (Canada, Israel)

- 7-12€-ct/kWh for small thermosiphon systems (Australia, China, South Africa)

- $12-20 €$-ct/kWh for small pumped systems (Australia, Austria, Canada, Denmark, France)

- 8-14€-ct/kWh for larger pumped systems in multi-family homes (Austria, Canada, Denmark, France)

- $11-19 €-c t / k W h$ for small combined hot water and space heating systems (Austria, China, Denmark, Germany, South Africa).

Analysis of Danish large-scale solar district heating (SDH) systems shows that economies of scale enable a huge potential for cost reduction: while the average LCOH for small domestic applications in Denmark ranges between $18.5 €$-ct/kWh for COMBI-SFH and $12.1 €$-ct/kWh for DHW-MFH, the average LCOH for large-scale systems $\left(>10,000 \mathrm{~m}^{2}\right)$ including the cost for a diurnal storage goes

Respective currency exchange rates by January 2016 (https://www.oanda.com/currency/converter) 


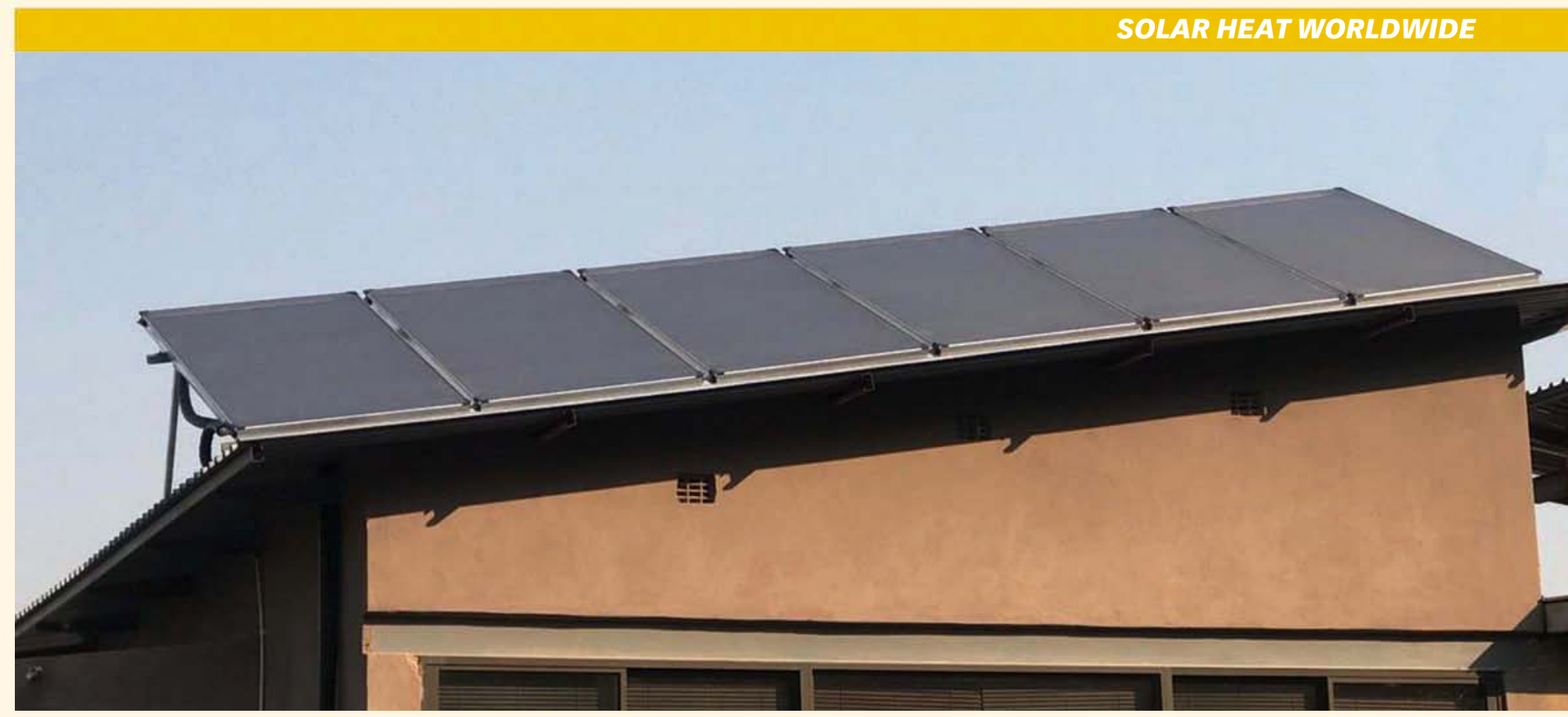

$14 \mathrm{~m}^{2}$ flat plate collectors at Thatch View Lodge, South Africa

down to $3.6 €$-ct/kWh. For even larger systems $\left(>50,000 \mathrm{~m}^{2}\right)$ with seasonal storage attached a $\mathrm{LCOH}$ of $4.9 €$-ct/kWh is achieved. The low $\mathrm{LCOH}$ in combination with a tax on natural gas makes large-scale solar thermal a commercial business case for district heating (consumer) co-operatives all over Denmark. (See Chapter $\mathbf{4 . 2}$ for further information.)

In Figure 57, specific solar thermal system costs in $€ / \mathrm{m}^{2}$ gross are highlighted in blue boxplots for (small-scale) domestic as well as for (large-scale) commercial solar thermal applications in Denmark. The corresponding levelized cost of solar thermal generated heat $(\mathrm{LCOH})$ in $€$-ct/kWh is shown as green bars (a green diamond equals the average value).

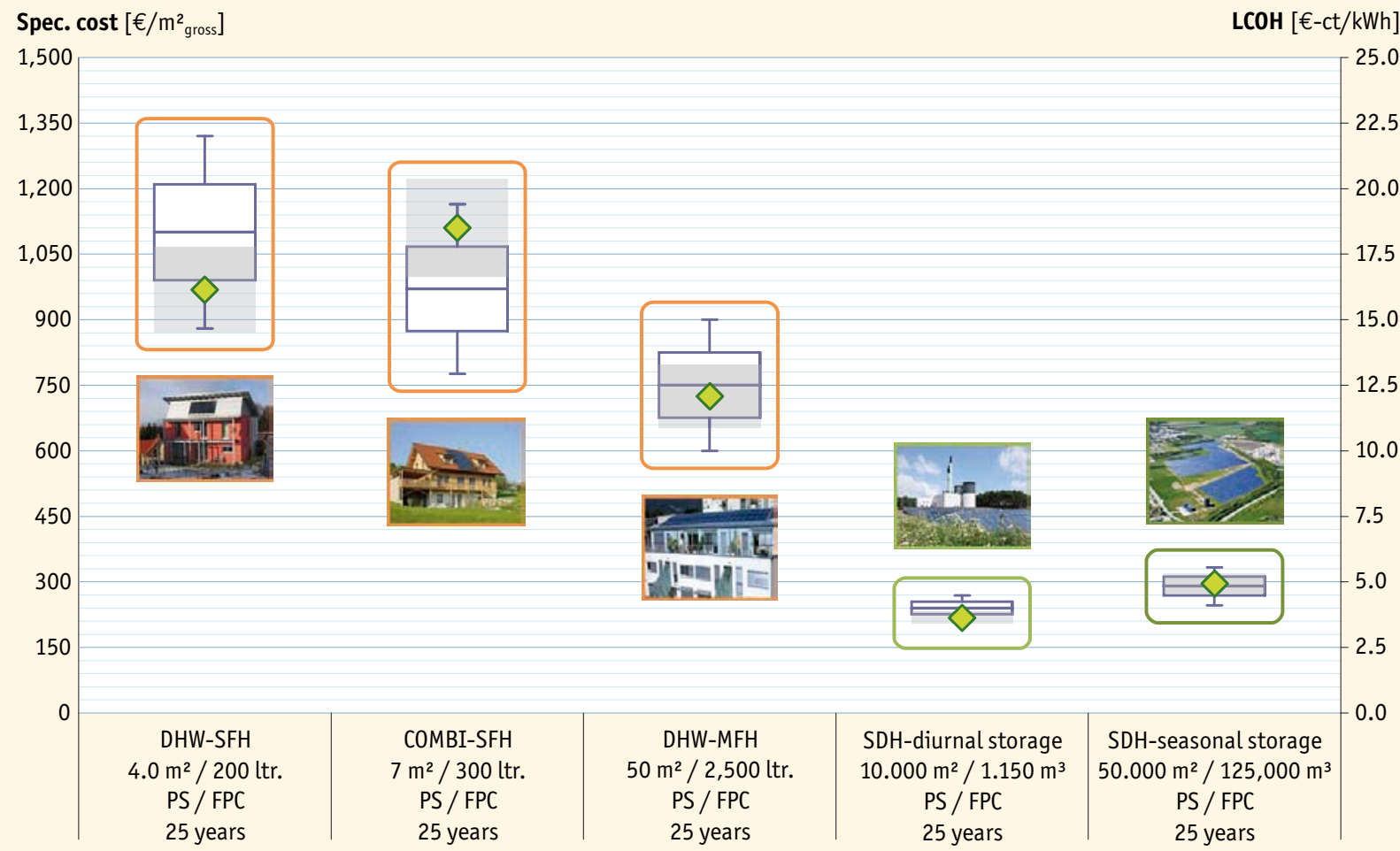

Figure 57: $\quad$ Specific investment costs and levelized costs of heat for different solar thermal applications in Denmark (orange: small-scale domestic systems, green: large-scale commercial applications) 
The majority of solar thermal systems installed worldwide are for domestic hot water preparation. Small domestic hot water systems for single-family homes as investigated in this chapter may differ by type of system (pumped systems, PS, or thermosiphon systems, TS) and/or by type of collector technology used (flat plate collector, FPC, or evacuated tube collector, ETC). Pumped systems are common in central and northern Europe as well as in North America and Australia, whereas thermosiphon systems are more common in warm climates, such as in Africa, Latin America, southern Europe and the MENA region. In Australia, both types of systems are about evenly present. In China, evacuated tube collectors in combination with thermosiphon systems are dominant, but the share of pumped systems with either flat plate or evacuated tube collectors is increasing. Other countries analyzed in this chapter are dominated by systems with flat plate collectors.

In Figure 58, specific solar thermal system costs in $€ / \mathrm{m}^{2}$ gross are highlighted for small pumped DHW systems in different countries within a typical price range (the blue boxplots). The corresponding levelized cost of solar thermal generated heat (LCOH) in $€$-ct/kWh is shown as green bars (a green diamond equals the average value).

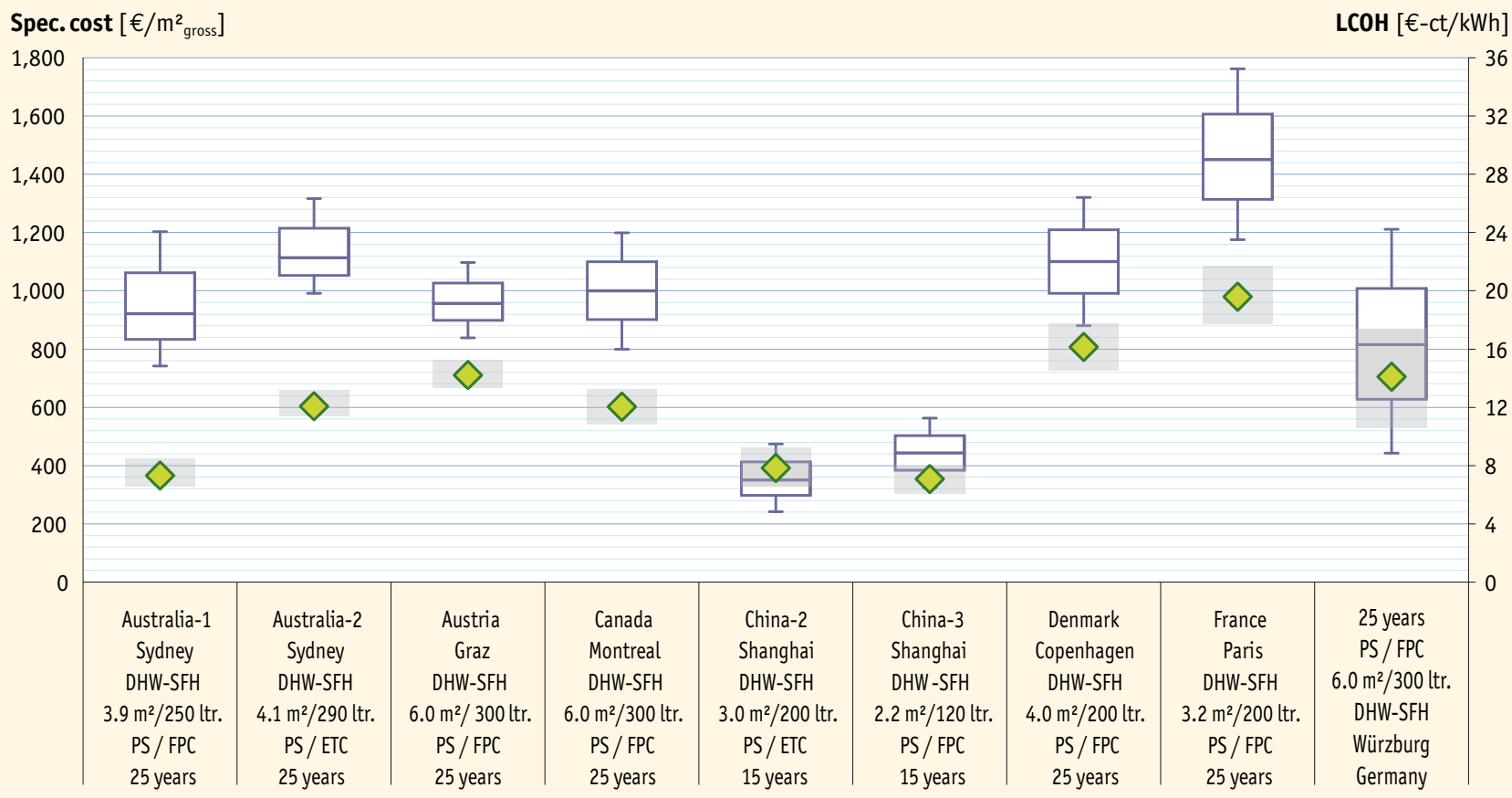

Figure 58: $\quad$ Specific investment costs and levelized costs of solar thermal generated heat for small pumped domestic hot water systems

The pumped solar water heating systems for single-family homes presented above have a collector area in the range between $2.2 \mathrm{~m}^{2}$ (China) and $6 \mathrm{~m}^{2}$ (Austria, Canada, Germany) and corresponding hot water storages between 120 liter and 300 liter. Flat plate collectors as well as evacuated tube collectors are used for this type of system.

Based on long-term experiences, service lifetime of the systems of between 15 years (China) and 25 years (all other countries) were taken as a basis for the calculation of the $\mathrm{LCOH}$. Depending on the lifetime above as well as the end consumer costand the respective climatic conditions the LCOH for small pumped hot water systems is between $7-19 €-\mathrm{ct} / \mathrm{kWh}$. The lowest cost for solar heat is in 
Australia and China. In central and northern Europe (Austria, Denmark, France and Germany) and Canada the cost of solar heat is about twice as high. The type of collector used seems not to have a significant influence on the cost of solar heat.

In Figure 59, specific solar thermal system costs in $€ / \mathrm{m}^{2}$ gross are highlighted for small thermosiphon DHW systems in different countries within a typical price range (blue boxplots). The corresponding levelized cost of solar thermal generated heat ( $(\mathrm{COH})$ in $€$-ct/kWh is shown as green bars (a green diamond equals the average value).

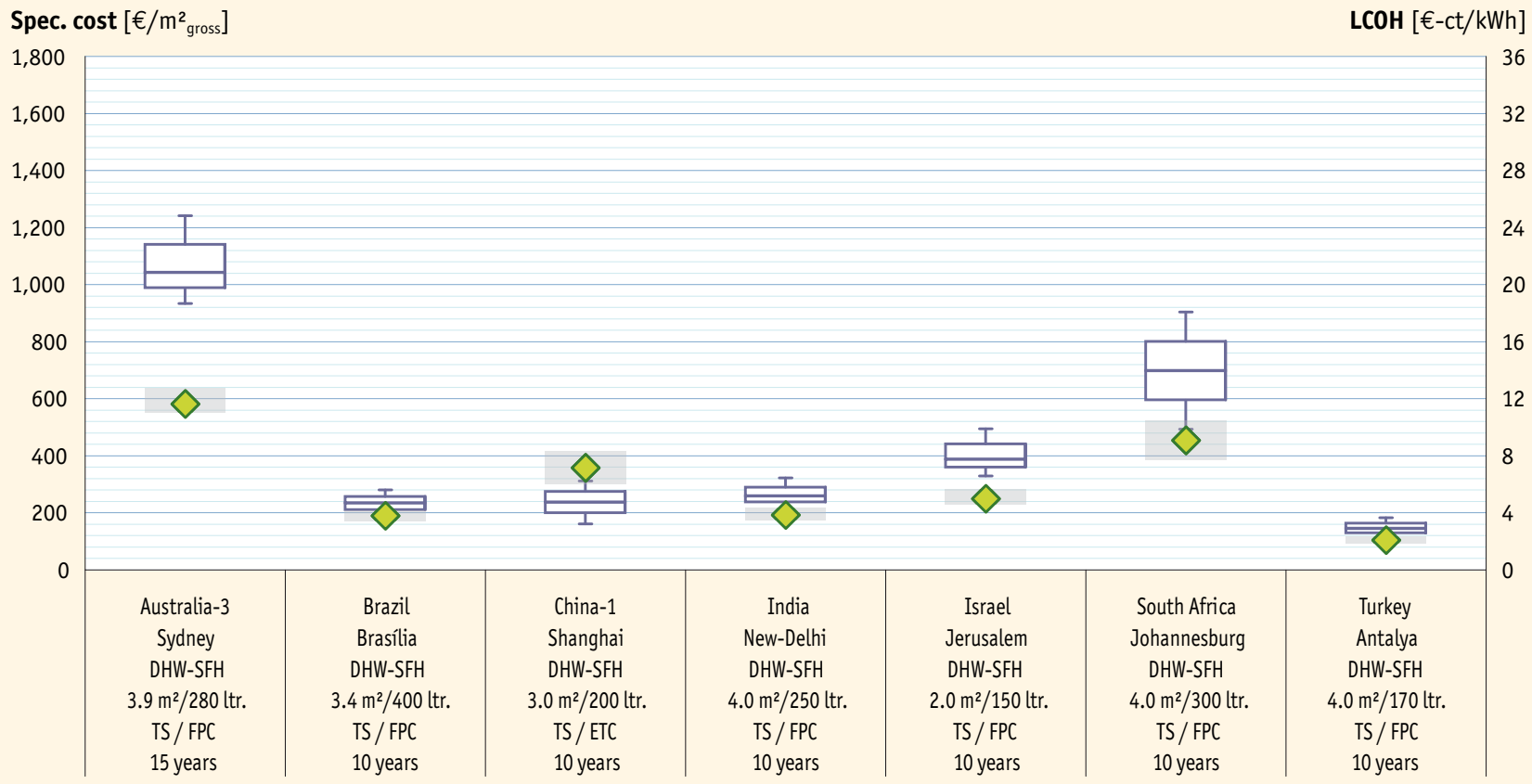

Figure 59: $\quad$ Specific investment costs and levelized costs of solar thermal generated heat for small thermosiphon domestic hot water systems

The thermosiphon solar water heating systems for single-family homes presented above have a collector area in the range between $2 \mathrm{~m}^{2}$ (Israel) and $4 \mathrm{~m}^{2}$ (India, South Africa, Turkey) and corresponding hot water storages between 150 liter and 400 liter. Flat-plate as well as evacuated tube collectors are also used for thermosiphon systems.

Service lifetimes of these systems are between 10 and 15 years depending on the system quality. Depending on the lifetime defined above as well as the end consumer cost and the respective climatic conditions the LCOH for thermosiphon hot water systems are between $2.1 €$-ct/kWh (Turkey) and $11.6 €-c t / k W h$ (Australia). 
In Figure 60, specific solar thermal system costs in $€ / \mathrm{m}^{2}$ gross are highlighted for large pumped DHW systems and for different countries within a typical price range (blue boxplots). The corresponding levelized cost of solar thermal generated heat (LCOH) in $€$-ct/kWh is shown as green bars (a green diamond equals the average value).

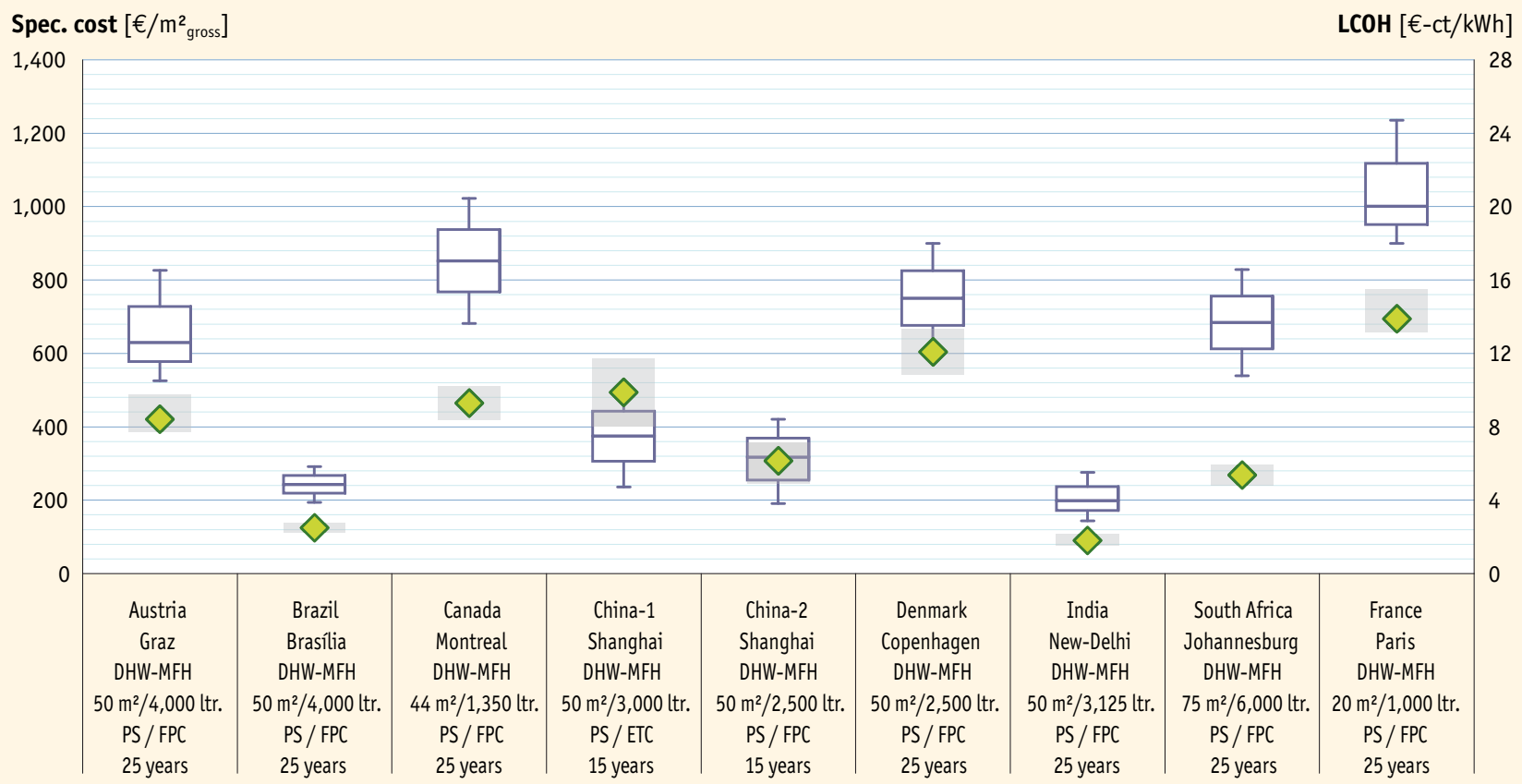

Figure 60: $\quad$ Specific investment costs and levelized costs of solar thermal generated heat for large pumped domestic hot water systems

Larger pumped solar water heating systems for multi-family homes, hotels and hospitals presented above have a collector area in the range between $20 \mathrm{~m}^{2}$ (France) and $75 \mathrm{~m}^{2}$ (South Africa) and corresponding hot water storages between 1,000 liter and 6,000 liter. Flat plate collectors as well as evacuated tube collectors are used for this type of systems.

Based on long-term experiences the service lifetime of the systems is between 15 years (China) and 25 years (all other countries) and served as a basis for the calculation of the $\mathrm{LCOH}$. Depending on the lifetime defined above as well as the end consumer cost and the respective climatic conditions, the $\mathrm{LCOH}$ for larger pumped hot water systems is in the range between $2-14 €$-ct/ $\mathrm{kWh}$. The lowest cost for solar heat is achieved in India and Brazil. In Denmark and France, the highest cost of solar heat is $12 €-\mathrm{ct} / \mathrm{kWh}$ and $14 €-c t / k W h$, respectively. 


\section{3

In Figure 61, specific solar thermal system costs in $€ / \mathrm{m}^{2}$ gross are highlighted for small combined hot water and space heating systems in different countries within a typical price range (blue boxplots). The corresponding levelized cost of solar thermal generated heat $(\mathrm{LCOH})$ in $€$-ct/kWh is shown as green bars (a green diamond equals the average value).

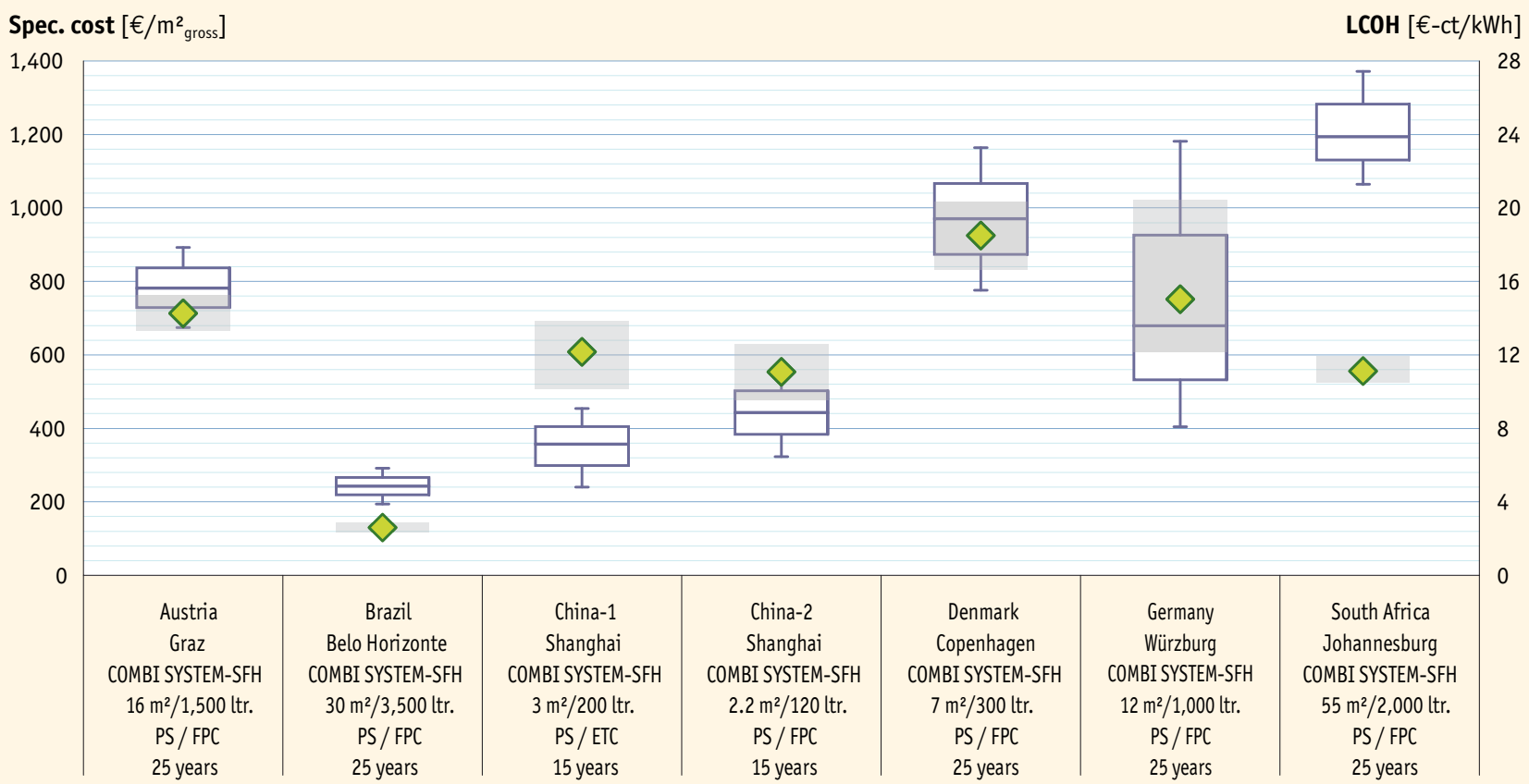

Figure 61: $\quad$ Specific investment costs and levelized costs of solar thermal generated heat for small combined hot water and space heating systems

The investigated solar combi-systems (used in single-family homes for hot water preparation and for space heating in the winter) have collector areas in the range between $2.2 \mathrm{~m}^{2}$ (China) and $55 \mathrm{~m}^{2}$ (South Africa) and corresponding hot water storages between 120 liter and 2,000 liter. Flat plate collectors are used predominantly for these applications.

Depending on the collector size of the systems and the climatic conditions the corresponding solar fraction of these systems has quite a broad variation. The service lifetime of the systems is between 15 years (China) and 25 years (all other countries ${ }^{28}$ ).

Depending on the lifetime defined above as well as the end consumer cost and the respective climatic conditions the LCOH for solar combi-systems is lowest in Brazil ( $3 €$-ct/kWh). In the other countries investigated the LCOH is between 11 and $18.5 €-\mathrm{ct} / \mathrm{kWh}$. 


\section{4 \\ Swimming pool heating systems}

In Figure 62, specific solar thermal system costs in $€ / \mathrm{m}^{2}$ gross are highlighted for swimming pool heating systems with unglazed water collectors in different countries within a typical price range (blue boxplots). The corresponding levelized cost of solar thermal generated heat $(\mathrm{LCOH})$ in $€-\mathrm{ct} / \mathrm{kWh}$ is shown as green bars (a green diamond equals the average value).

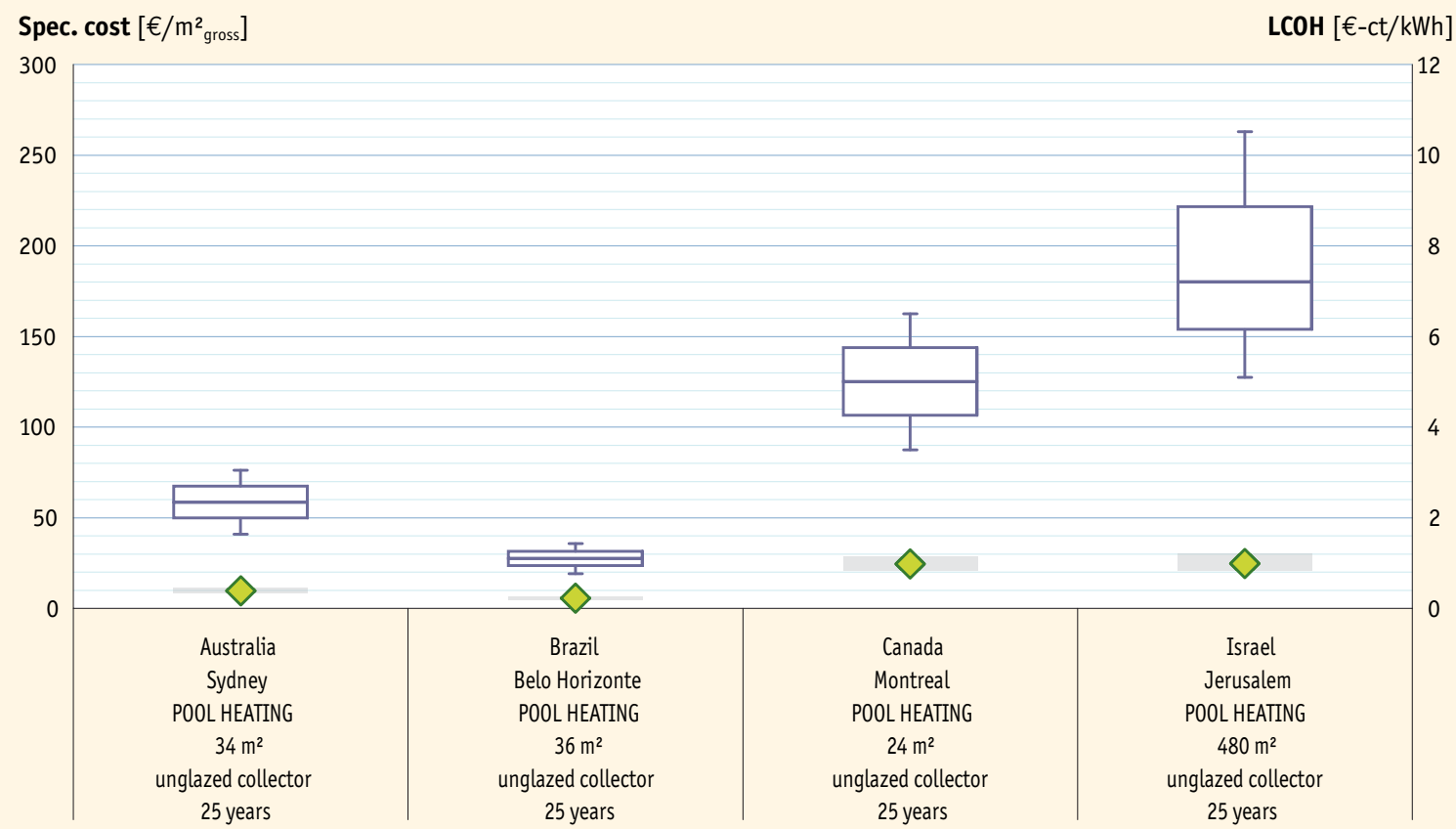

Figure 62: $\quad$ Specific investment costs and levelized costs of solar thermal generated heat for swimming pool heating systems

Swimming pool heating is the most economical solar water heating system. The $\mathrm{LCOH}$ has a range of $1-2 €$-ct/kWh. 


\section{$9.1 \quad$ Methodological approach for the energy calculation}

In order to obtain the energy yield of solar thermal systems, the oil equivalent saved and the $\mathrm{CO}_{2}$ emissions avoided, the following procedure was used:

- Only water collectors were used in the calculations (unglazed water collectors, flat-plate collectors and evacuated tube collectors). Air collectors were not included.

- For each country, the cumulated water collector area was allocated to the following applications (based on available country market data):

- Solar thermal systems for swimming pool heating

Solar domestic hot water systems for single-family houses,

- Solar domestic hotwater systems for multifamily houses including the tourism sector as well as the public sector (to simplify the analysis solar district heating systems, solar process heat and solar cooling applications were also allocated here), and

- Solar combi-systems for domestic hot water and space heating for single- and multi-family houses.

- Reference systems were defined for each country and for each type of application (pumped or thermosiphon solar thermal system).

- The number of systems per country was determined from the share of collector area for each application and the collector area defined for the reference system.

Apart from the reference applications and systems mentioned above, reference collectors and reference climates were determined. On the basis of these boundary conditions, simulations were performed with the simulation program T-Sol [T-Sol, Version 4.5 Expert, Valentin Energiesoftware, www.valentin-software.com] and gross solar yields for each country and each system were obtained. The gross solar yields refer to the solar collector heat output and do not include heat losses through transmission piping or storage heat losses ${ }^{29}$.

The amount of final energy saved is calculated from the gross solar yields considering a utilization rate of the auxiliary heating system of 0.8 . Final energy savings are expressed in tons of oil equivalent (toe): 1 toe $=11,630 \mathrm{kWh}$.

Finally, the $\mathrm{CO}_{2}$ emissions avoided by the different solar thermal applications are quoted as kilograms carbon dioxide equivalent $\left(\mathrm{kgCO}_{2} \mathrm{e}\right)$ per tons of oil equivalent: 1 toe $=3.228 \mathrm{tCO}_{2} \mathrm{e}^{30}$. The emission factor only account for direct emissions.

To obtain an exact statement about the $\mathrm{CO}_{2}$ emissions avoided, the substituted energy medium would have to be ascertained for each country. Since this could only be done in a very detailed survey, which goes beyond the scope of this report, the energy savings and the $\mathrm{CO}_{2}$ emissions avoided therefore relate to fuel oil. It is obvious that not all solar thermal systems just replace systems running on oil. This represents a simplification since gas, coal, biomass or electricity can be used as an energy source for the auxiliary heating system instead of oil.

The following tables describe the key data of the reference systems in the different countries, the location of the reference climate used and the share of the total collector area in use for the respective application. Furthermore, a hydraulic scheme is shown for each reference system.

29 Using gross solaryields for the energy calculations is based on a definition for Renewable Heat by EUROSTAT and IEA SHC. In editions of this report prior to 2011 solaryields calculated included heat losses through transmission piping and hence energy savings considered were about 5 to $15 \%$ less depending on the system, the application and the climate.

30 Source: Defra /DECC 2013 
9.1 .1

\section{Reference systems for swimming pool heating}

The information in Table 8 refers to the total capacity of water collectors in operation used for swimming pool heating as reported from each country by the end of 2016.

\begin{tabular}{|c|c|c|c|c|c|c|}
\hline Country* & $\begin{array}{l}\text { Reference } \\
\text { climate }\end{array}$ & $\begin{array}{l}\text { Horizontal } \\
\text { irradiation } \\
{\left[\mathrm{kWh} / \mathrm{m}^{2} \cdot \mathrm{a}\right]}\end{array}$ & $\begin{array}{c}\text { Total collector } \\
\text { area (swimming } \\
\text { pool) } \\
{\left[\mathrm{m}^{2}\right]}\end{array}$ & $\begin{array}{c}\text { Collector area } \\
\text { per system } \\
{\left[\mathrm{m}^{2}\right]}\end{array}$ & $\begin{array}{l}\text { Total number of } \\
\text { systems }\end{array}$ & $\begin{array}{c}\text { Specific solar } \\
\text { yield (swimming } \\
\text { pool) } \\
{\left[\mathrm{kWh} / \mathrm{m}^{2} \cdot \mathrm{a}\right]}\end{array}$ \\
\hline Australia & Sydney & $1,674.0$ & $5,103,740$ & 35 & 145,821 & 466 \\
\hline Austria & Graz & $1,126.0$ & 590,199 & 200 & 2,951 & 283 \\
\hline Belgium & Brussels & 971.1 & 29,303 & 200 & 147 & 262 \\
\hline Brazil & Brasília & $1,792.5$ & $4,435,725$ & 32 & 138,616 & 375 \\
\hline Bulgaria & Sofia & $1,187.5$ & 6,412 & 200 & 32 & 320 \\
\hline Canada & Montreal & $1,351.4$ & 540,379 & 25 & 21,615 & 386 \\
\hline Chile & Santiago de Chile & $1,752.7$ & 61,809 & 15 & 4,121 & 473 \\
\hline Croatia & Zagreb & $1,212.0$ & 9,798 & 200 & 49 & 327 \\
\hline Cyprus & Nicosia & $1,885.5$ & 1,657 & 200 & 8 & 508 \\
\hline Czech Republic & Praha & 998.4 & 671,211 & 200 & 3,356 & 303 \\
\hline Estonia & Tallin & 960.2 & 677 & 200 & 3 & 259 \\
\hline Finland & Helsinki & 948.0 & 3,115 & 200 & 16 & 256 \\
\hline France (mainland) & Paris & $1,112.4$ & 119,807 & 200 & 599 & 328 \\
\hline Germany & Würzburq & $1,091.3$ & 592,792 & 30 & 19,760 & 314 \\
\hline Greece & Athens & $1,584.6$ & 209,750 & 200 & 1,049 & 427 \\
\hline Hungary & Budapest & $1,198.7$ & 34,252 & 10 & 3,425 & 344 \\
\hline India & Neu-Delhi & $1,960.5$ & 95,334 & 16 & 5,958 & 529 \\
\hline Israel & Jerusalem & $2,198.0$ & 185,377 & 200 & 927 & 568 \\
\hline Italy & Bologna & $1,419.0$ & 205,636 & 200 & 1,028 & 442 \\
\hline Jordan & Amman & $2,145.4$ & 6,661 & 200 & 33 & 578 \\
\hline Korea, South & Seoul & $1,161.1$ & 14,919 & 200 & 75 & 313 \\
\hline Latvia & Riga & 991.2 & 575 & 200 & 3 & 267 \\
\hline Lebanon & Beirut & $1,934.5$ & 27,325 & 17 & 1,656 & 522 \\
\hline Lithuania & Vilnius & $1,001.2$ & 690 & 200 & 3 & 270 \\
\hline Luxembourg & Luxembourg & $1,037.4$ & 2,805 & 200 & 14 & 280 \\
\hline Macedonia & Skopje & $1,380.8$ & 651 & 20 & 33 & 372 \\
\hline Malta & Luqa & $1,901.9$ & 2,410 & 200 & 12 & 513 \\
\hline Mexico & Mexico City & $1,706.3$ & $1,205,643$ & 200 & 6,028 & 311 \\
\hline Morocco & Rabat & $2,000.0$ & 18,040 & 200 & 90 & 539 \\
\hline Netherlands & Amsterdam & 999.0 & 110,875 & 40 & 2,772 & 272 \\
\hline New Zealand & Wellington & $1,401.2$ & 11,175 & 200 & 56 & 378 \\
\hline Norway & Oslo & 971.1 & 2,111 & 200 & 11 & 316 \\
\hline Palestinian Territories & Jerusalem & $2,198.0$ & 73,394 & 200 & 367 & 593 \\
\hline Portugal & Lisbon & $1,686.4$ & 5,101 & 200 & 26 & 421 \\
\hline Romania & Bucharest & $1,324.3$ & 8,138 & 200 & 41 & 357 \\
\hline Russia & Moscow & 996.0 & 189 & 200 & 1 & 269 \\
\hline Slovakia & Bratislava & $1,213.8$ & 7,513 & 200 & 38 & 327 \\
\hline Slovenia & Ljubjana & $1,114.6$ & 1,468 & 200 & 7 & 301 \\
\hline South Africa & Johannesburg & $2,075.1$ & $1,109,120$ & 40 & 27,728 & 505 \\
\hline Spain & Madrid & $1,643.5$ & 195,189 & 200 & 976 & 472 \\
\hline Sweden & Gothenburg & 933.9 & 155,815 & 200 & 779 & 295 \\
\hline Switzerland & Zürich & $1,093.8$ & 270,825 & 200 & 1,354 & 277 \\
\hline Taiwan & Taipei & $1,372.2$ & 13,513 & 175 & 77 & 319 \\
\hline Thailand & Bangkok & $1,764.8$ & 1,804 & 300 & 4 & 476 \\
\hline United Kingdom & London & 942.6 & 37,223 & 200 & 186 & 254 \\
\hline United States & LA, Indianapolis & $1,646.1$ & $20,074,308$ & 200 & 100,372 & 387 \\
\hline \multirow[t]{3}{*}{ All other countries ( $5 \%$ ] } & & $1,460.8$ & $1,975,458$ & 200 & 9,876 & 394 \\
\hline & TOTAL & & $38,229,911$ & & 502,098 & \\
\hline & AVERAGE & 1,415 & & 161 & & 394 \\
\hline
\end{tabular}

* Countries not listed in this table did not reportany share of collectors used for swimming pool heating.

Table 8: $\quad$ Solar thermal systems for swimming pool heating in 2016

Figure 63 shows the hydraulic scheme of the swimming pool reference system as used for the simulations of the solar energy yields. Figure 64 shows the hydraulic scheme used for the energy calculation for all pumped solar thermal systems and Figure 65 refers to the thermosiphon systems. For the Chinese thermosiphon systems the reference system above was used, but instead of a flat plate collector as shown in Figure 65 a representative Chinese vacuum tube collector was used for the simulation.

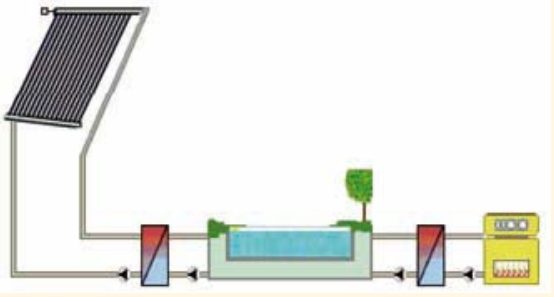

Figures 63, 64, 65: Hydraulic scheme of the swimming pool reference system system for single-family houses

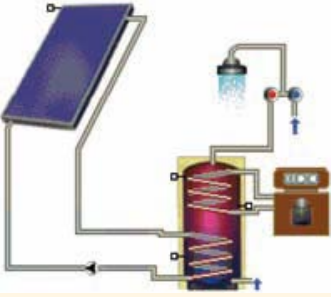

Hydraulic scheme of the domestic hot water pumped reference

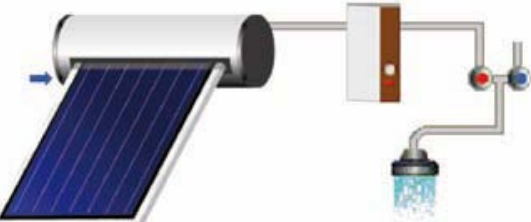

Hydraulic scheme of the domestic hot water thermosiphon reference system for single-family houses 
The information in Table 9 refers to the total capacity of water collectors in operation used for domestic hot water heating in singlefamily houses at the end of 2016 as reported by each country.

\begin{tabular}{|c|c|c|c|c|c|c|c|}
\hline Country & $\begin{array}{l}\text { Reference } \\
\text { climate }\end{array}$ & $\begin{array}{l}\text { Horizontal } \\
\text { irradiation } \\
{\left[\mathrm{kWh} / \mathrm{m}^{2} \cdot \mathrm{a}\right]}\end{array}$ & $\begin{array}{c}\text { Total coll. area } \\
\text { (DHW-SFH) } \\
{\left[\mathrm{m}^{2}\right]}\end{array}$ & $\begin{array}{c}\text { Coll. area } \\
\text { per system } \\
{\left[\mathrm{m}^{2}\right]}\end{array}$ & $\begin{array}{c}\text { Total } \\
\text { number of } \\
\text { systems }\end{array}$ & $\begin{array}{c}\text { Specific solar } \\
\text { yield (DHW-SFH) } \\
{\left[\mathrm{kWh} / \mathrm{m}^{2} \cdot \mathrm{a}\right]}\end{array}$ & $\begin{array}{l}\text { Type of } \\
\text { system }\end{array}$ \\
\hline Albania & Tirana & 1,604 & 124,355 & 3.0 & 41,452 & 713 & TS \\
\hline Australia & Sydney & 1,674 & $3,390,720$ & 3.5 & 968,777 & 844 & PS \\
\hline Austria & Graz & 1,126 & $2,167,454$ & 6.0 & 361,242 & 451 & PS \\
\hline Barbados & Grantley Adams & 2,016 & 214,290 & 4.0 & 53,573 & 882 & TS \\
\hline Belgium & Brussels & 971 & 389,327 & 4.0 & 97,332 & 423 & PDS/PS \\
\hline Botswana & Gaborone & 2,161 & 5,700 & 4.0 & 1,425 & 961 & TS \\
\hline Brazil & Brasília & 1,793 & $7,851,648$ & 2.0 & $3,925,824$ & 809 & TS \\
\hline Bulgaria & Sofia & 1,188 & 85,198 & 4.0 & 21,299 & 524 & PS \\
\hline Burkina Faso & Ouagadougou & 2,212 & 148 & 4.0 & 37 & 983 & TS \\
\hline Canada & Montreal & 1,351 & 40,720 & 6.0 & 6,787 & 556 & PS \\
\hline Chile & Santiago de Chile & 1,753 & 107,874 & 2.0 & 53,937 & 771 & PS \\
\hline China & Shanghai & 1,282 & $301,326,999$ & 4.0 & $75,331,750$ & 592 & TS \\
\hline Croatia & Zagreb & 1,212 & 130,177 & 4.0 & 32,544 & 539 & PS \\
\hline Cyprus & Nicosia & 1,886 & 595,679 & 2.0 & 297,840 & 912 & TS \\
\hline Czech Republic & Praha & 998 & 252,317 & 4.7 & 53,684 & 385 & PS \\
\hline Denmark & Copenhagen & 989 & 256,352 & 4.0 & 64,088 & 454 & PS \\
\hline Estonia & Tallin & 960 & 8,997 & 4.0 & 2,249 & 432 & PS \\
\hline Finland & Helsinki & 948 & 41,391 & 4.0 & 10,348 & 441 & PS \\
\hline France & Paris & 1,112 & $1,446,560$ & 3.2 & 452,050 & 496 & PS \\
\hline Germany & Würzburq & 1,091 & $8,449,245$ & 5.6 & $1,508,794$ & 424 & PS \\
\hline Ghana & Accra & 2,146 & 200 & 4.0 & 50 & 954 & TS \\
\hline Greece & Athens & 1,585 & $2,786,799$ & 2.5 & $1,114,720$ & 772 & TS \\
\hline Hungary & Budapest & 1,199 & 171,437 & 5.0 & 34,287 & 473 & PS \\
\hline India & Neu-Delhi & 1,961 & $8,341,735$ & 2.0 & $4,170,867$ & 882 & TS \\
\hline Ireland & Dublin & 949 & 308,926 & 4.0 & 77,231 & 423 & PS \\
\hline Israel & Jerusalem & 2,198 & 834,198 & 3.0 & 278,066 & 1,024 & TS \\
\hline Italy & Bologna & 1,419 & $2,732,129$ & 4.0 & 683,032 & 661 & PS \\
\hline Japan & Tokyo & 1,175 & $3,359,578$ & 4.0 & 839,895 & 586 & TS \\
\hline Jordan & Amman & 2,145 & $1,003,076$ & 4.6 & 218,060 & 986 & TS \\
\hline Korea, South & Seoul & 1,161 & $1,678,805$ & 4.0 & 419,701 & 525 & PS \\
\hline Latvia & Riga & 991 & 7,641 & 4.0 & 1,910 & 462 & PS \\
\hline Lebanon & Beirut & 1,935 & 403,048 & 4.0 & 100,762 & 860 & TS \\
\hline Lesotho & Maseru & 2,050 & 500 & 2.0 & 250 & 911 & TS \\
\hline Lithuania & Vilnius & 1,001 & 9,170 & 4.0 & 2,293 & 450 & PS \\
\hline Luxembourg & Luxembourg & 1,037 & 37,261 & 4.0 & 9,315 & 450 & PS \\
\hline Macedonia & Skopje & 1,381 & 58,556 & 4.0 & 14,639 & 627 & PS \\
\hline Malta & Luqa & 1,902 & 32,016 & 2.5 & 12,807 & 868 & PS \\
\hline Mauritius & Port Louis & 1,920 & 132,793 & 1.5 & 88,529 & 854 & TS \\
\hline Mexico & Mexico City & 1,706 & $1,519,110$ & 4.0 & 379,778 & 718 & PS \\
\hline Morocco & Rabat & 2,000 & 225,500 & 4.0 & 56,375 & 889 & TS \\
\hline Mozambique & Maputo & 1,910 & 1,386 & 4.0 & 347 & 849 & TS \\
\hline Namibia & Windhoek & 2,363 & 17,054 & 4.0 & 4,264 & 1,032 & TS \\
\hline Netherlands & Amsterdam & 999 & 404,367 & 2.8 & 144,417 & 433 & PDS / PS \\
\hline New Zealand & Wellington & 1,401 & 127,716 & 4.0 & 31,929 & 647 & PS \\
\hline Nigeria & Abuja & 2,007 & 254 & 4.0 & 63 & 892 & TS \\
\hline Norway & Oslo & 971 & 1,754 & 6.0 & 292 & 430 & PS \\
\hline Palestinian Ter. & Jerusalem & 2,198 & 917,425 & 1.5 & 611,617 & 977 & TS \\
\hline Poland & Warsaw & 1,024 & $1,496,040$ & 6.0 & 249,340 & 397 & PS \\
\hline Portugal & Lisbon & 1,686 & 708,992 & 4.0 & 177,248 & 804 & PS \\
\hline Romania & Bucharest & 1,324 & 108,117 & 4.0 & 27,029 & 594 & PS \\
\hline Russia & Moscow & 996 & 3,232 & 4.0 & 808 & 443 & PS \\
\hline Senegal & Dakar & 2,197 & 1,682 & 4.0 & 420 & 977 & TS \\
\hline Slovakia & Bratislava & 1,214 & 99,821 & 6.0 & 16,637 & 481 & PS \\
\hline Slovenia & Ljubjana & 1,115 & 132,120 & 6.0 & 22,020 & 424 & PS \\
\hline South Africa & Johannesburg & 2,075 & 771,213 & 1.9 & 405,902 & 1,009 & TS \\
\hline Spain & Madrid & 1,644 & $1,561,515$ & 4.0 & 390,379 & 766 & PS \\
\hline Sweden & Gothenburg & 934 & 40,752 & 4.0 & 10,188 & 383 & PS \\
\hline Switzerland & Zürich & 1,094 & 904,048 & 5.7 & 158,605 & 426 & PS \\
\hline Taiwan & Taipei & 1,372 & $1,586,110$ & 4.8 & 330,440 & 616 & PS \\
\hline Thailand & Bangkok & 1,765 & 142,833 & 4.0 & 35,708 & 854 & TS \\
\hline Tunisia & Tunis & 1,808 & 905,989 & 3.3 & 274,542 & 902 & TS \\
\hline Turkey & Antalya & 1,795 & $19,626,025$ & 4.0 & $4,906,506$ & 910 & TS \\
\hline United Kingdom & London & 943 & 494,561 & 4.0 & 123,640 & 415 & PS \\
\hline United States & LA, Indianapolis & 1,646 & $1,505,573$ & 6.0 & 250,929 & 646 & PS \\
\hline Uruguay & Montevideo & 1,534 & 58,247 & 4.0 & 14,562 & 682 & TS \\
\hline Zimbabwe & Harare & 2,017 & 27,795 & 2.0 & 13,898 & 854 & TS \\
\hline \multirow[t]{3}{*}{ All other countries ( $5 \%)$} & & 1,403 & $26,139,560$ & 4.0 & $6,534,890$ & 624 & TS/PS \\
\hline & TOTAL & & $408,311,812$ & & $106,524,217$ & & \\
\hline & AVERAGE & 1,517 & & 4 & & 624 & \\
\hline
\end{tabular}

PS: pumped system TS: thermosiphon system PDS: pumpeddrain backsystem

Table 9: $\quad$ Solar thermal systems for domestic hot water heating in single-family houses by the end of 2016 


\subsubsection{Reference systems for domestic hot water preparation in multifamily houses}

The information in Table 10 refers to the total capacity of water collectors in operation used for domestic hot water heating in multifamily houses at the end of 2016 as reported by each country.

\begin{tabular}{|c|c|c|c|c|c|c|}
\hline Country & $\begin{array}{l}\text { Reference } \\
\text { climate }\end{array}$ & $\begin{array}{l}\text { Horizontal } \\
\text { irradiation } \\
{\left[\mathrm{kWh} / \mathrm{m}^{2} \cdot \mathrm{a}\right]}\end{array}$ & $\begin{array}{c}\text { Total collector area } \\
(\mathrm{DHW}-\mathrm{MFH}) \\
{\left[\mathrm{m}^{2}\right]}\end{array}$ & $\begin{array}{c}\text { Collector area per } \\
\text { system } \\
{\left[\mathrm{m}^{2}\right]}\end{array}$ & $\begin{array}{l}\text { Total number of } \\
\text { systems }\end{array}$ & $\begin{array}{c}\text { Specific solar yield } \\
\text { (DHW-MFH) } \\
\text { kWh/m } / \mathrm{m}^{2} \cdot a\end{array}$ \\
\hline Albania & Tirana & 1,604 & 82,903 & 50.0 & 1,658 & 694 \\
\hline Australia & Sydney & 1,674 & 335,540 & 50.0 & 6,711 & 725 \\
\hline Austria & Graz & 1,126 & 404,257 & 50.0 & 8,085 & 505 \\
\hline Belgium & Brussels & 971 & 88,526 & 50.0 & 1,771 & 405 \\
\hline Botswana & Gaborone & 2,161 & 3,800 & 30.0 & 127 & 902 \\
\hline Brazil & Brasília & 1,793 & $1,362,514$ & 60.0 & 22,709 & 658 \\
\hline Bulgaria & Sofia & 1,188 & 19,372 & 50.0 & 387 & 515 \\
\hline Burkina Faso & Ouagadougou & 2,212 & 923 & 30.0 & 31 & 923 \\
\hline Canada & Montreal & 1,351 & 344,273 & 50.0 & 6,885 & 621 \\
\hline Chile & Santiago de Chile & 1,753 & 121,868 & 50.0 & 2,437 & 732 \\
\hline China & Shanghai & 1,282 & $162,253,000$ & 50.0 & $3,245,060$ & 502 \\
\hline Croatia & Zagreb & 1,212 & 29,600 & 50.0 & 592 & 506 \\
\hline Cyprus & Nicosia & 1,886 & 78,830 & 50.0 & 1,577 & 750 \\
\hline Czech Republic & Praha & 998 & 38,495 & 42.4 & 908 & 436 \\
\hline Denmark & Copenhagen & 989 & $1,319,316$ & 50.0 & 26,386 & 413 \\
\hline Estonia & Tallin & 960 & 2,046 & 50.0 & 41 & 401 \\
\hline Finland & Helsinki & 948 & 9,411 & 50.0 & 188 & 396 \\
\hline France & Paris & 1,112 & 652,440 & 20.0 & 32,622 & 489 \\
\hline Germany & Würzburg & 1,091 & $2,283,413$ & 50.0 & 45,668 & 472 \\
\hline Ghana & Accra & 2,146 & 2,074 & 30.0 & 69 & 896 \\
\hline Greece & Athens & 1,585 & 633,667 & 50.0 & 12,673 & 642 \\
\hline Hungary & Budapest & 1,199 & 29,124 & 50.0 & 582 & 522 \\
\hline India & Neu-Delhi & 1,961 & $1,096,342$ & 50.0 & 21,927 & 749 \\
\hline Ireland & Dublin & 949 & 10,298 & 50.0 & 206 & 425 \\
\hline Israel & Jerusalem & 2,198 & $3,614,859$ & 3.0 & $1,204,953$ & 917 \\
\hline Italy & Bologna & 1,419 & 621,236 & 50.0 & 12,425 & 592 \\
\hline Japan & Tokyo & 1,175 & 7,357 & 50.0 & 147 & 516 \\
\hline Jordan & Amman & 2,145 & 250,769 & 50.0 & 5,015 & 801 \\
\hline Korea, South & Seoul & 1,161 & 137,817 & 50.0 & 2,756 & 485 \\
\hline Latvia & Riga & 991 & 1,737 & 50.0 & 35 & 414 \\
\hline Lebanon & Beirut & 1,935 & 252,759 & 40.0 & 6,319 & 807 \\
\hline Lesotho & Maseru & 2,050 & 1,343 & 10.0 & 134 & 856 \\
\hline Lithuania & Vilnius & 1,001 & 2,085 & 50.0 & 42 & 418 \\
\hline Luxembourg & Luxembourg & 1,037 & 8,473 & 50.0 & 169 & 433 \\
\hline Macedonia & Skopje & 1,381 & 5,205 & 50.0 & 104 & 577 \\
\hline Malta & Luqa & 1,902 & 7,280 & 50.0 & 146 & 794 \\
\hline Mexico & Mexico City & 1,706 & 651,047 & 50.0 & 13,021 & 713 \\
\hline Morocco & Rabat & 2,000 & 202,950 & 50.0 & 4,059 & 835 \\
\hline Namibia & Windhoek & 2,363 & 20,844 & 50.0 & 417 & 814 \\
\hline Netherlands & Amsterdam & 999 & 104,353 & 40.0 & 2,609 & 418 \\
\hline New Zealand & Wellington & 1,401 & 15,965 & 50.0 & 319 & 585 \\
\hline Nigeria & Abuja & 2,007 & 101 & 1.4 & 72 & 838 \\
\hline Norway & Oslo & 971 & 19,187 & 50.0 & 384 & 406 \\
\hline Palestinian Territories & Jerusalem & 2,198 & 825,683 & 50.0 & 16,514 & 917 \\
\hline Poland & Warsaw & 1,024 & 534,300 & 50.0 & 10,686 & 447 \\
\hline Portugal & Lisbon & 1,686 & 306,040 & 40.0 & 7,651 & 705 \\
\hline Romania & Bucharest & 1,324 & 24,584 & 50.0 & 492 & 553 \\
\hline Russia & Moscow & 996 & 19,061 & 50.0 & 381 & 416 \\
\hline Senegal & Dakar & 2,197 & 52 & 4.5 & 12 & 917 \\
\hline Slovakia & Bratislava & 1,214 & 22,697 & 50.0 & 454 & 507 \\
\hline Slovenia & Ljubjana & 1,115 & 4,404 & 50.0 & 88 & 477 \\
\hline South Africa & Johannesburg & 2,075 & 28,086 & 87.0 & 323 & 866 \\
\hline Spain & Madrid & 1,644 & $1,834,780$ & 50.0 & 36,696 & 676 \\
\hline Sweden & Gothenburg & 934 & 55,135 & 50.0 & 1,103 & 430 \\
\hline Switzerland & Zürich & 1,094 & 107,946 & 20.0 & 5,397 & 457 \\
\hline Taiwan & Taipei & 1,372 & 89,525 & 30.0 & 2,984 & 518 \\
\hline Thailand & Bangkok & 1,765 & 11,726 & 80.0 & 147 & 737 \\
\hline Tunisia & Tunis & 1,808 & 907 & 50.0 & 18 & 755 \\
\hline Turkey & Antalya & 1,795 & $1,706,611$ & 80.0 & 21,333 & 749 \\
\hline United Kingdom & London & 943 & 112,454 & 50.0 & 2,249 & 393 \\
\hline United States & LA, Indianapolis & 1,646 & $3,513,004$ & 50.0 & 70,260 & 687 \\
\hline Zimbabwe & Harare & 2,017 & 9,265 & 32.0 & 290 & 842 \\
\hline \multirow[t]{3}{*}{ All other countries ( $5 \%)$} & & 1,256 & $3,294,073$ & 50.0 & 65,881 & 524 \\
\hline & TOTAL & & $189,627,730$ & & $4,935,384$ & \\
\hline & AVERAGE & 1,494 & & 46 & & 524 \\
\hline
\end{tabular}

Table 10: $\quad$ Solar thermal systems for domestic hot water heating in multifamily houses by the end of 2016 
Figure 66 shows the hydraulic scheme of domestic hot water reference system for multifamily houses as used for the simulations of the solar energy yields. As opposed to small-scale domestic hot water systems, all large-scale systems are assumed to be pumped solar thermal systems. Figure 67 shows the hydraulic scheme of domestic hot water reference system for multifamily houses as used for the simulations of the solar energy yields.

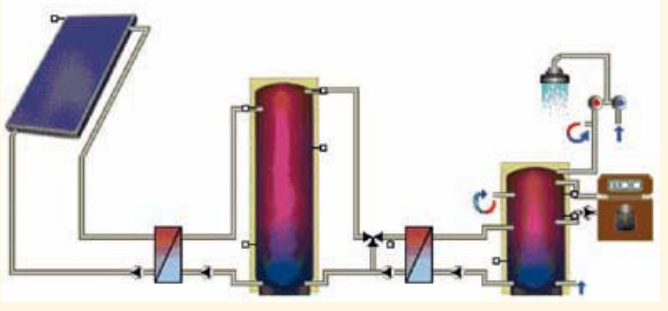

Figures 66, 67: Hydraulic scheme of the domestic hot water pumped reference system for multifamily houses

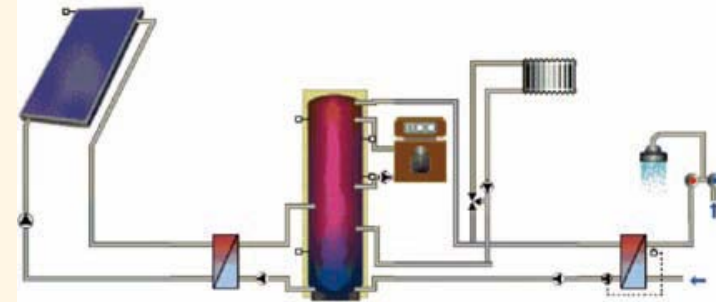

Hydraulic scheme of the solar-combi reference system for single and multifamily houses

9.1 .4

\section{Reference systems for domestic hot water preparation and space heating in single and} multifamily houses (solar combi-systems)

The information in Table 11 refers to the total capacity of water collectors in operation used for domestic hot water heating in multifamily houses at the end of 2016 as reported by each country.

\begin{tabular}{|c|c|c|c|c|c|c|}
\hline Country & $\begin{array}{l}\text { Reference } \\
\text { climate }\end{array}$ & $\begin{array}{l}\text { Horizontal } \\
\text { irradiation } \\
{\left[\mathrm{kWh} / \mathrm{m}^{2} \cdot \mathrm{a}\right]}\end{array}$ & $\begin{array}{l}\text { Total collector } \\
\text { area (Combi } \\
\text { systems) }\left[\mathrm{m}^{2}\right]\end{array}$ & $\begin{array}{c}\text { Collector area } \\
\text { per system } \\
{\left[\mathrm{m}^{2}\right]}\end{array}$ & $\begin{array}{l}\text { Total number } \\
\text { of systems }\end{array}$ & $\begin{array}{c}\text { Spec. solaryield } \\
\text { (Combi systems) } \\
{\left[\mathrm{kWh} / \mathrm{m}^{2} \cdot \mathrm{a}\right]}\end{array}$ \\
\hline Austria & Graz & 1,126 & $2,044,584$ & 14.0 & 146,042 & 369 \\
\hline Belgium & Brussels & 971 & 121,177 & 12.0 & 10,098 & 342 \\
\hline Bulgaria & Sofia & 1,188 & 26,518 & 12.0 & 2,210 & 418 \\
\hline Canada & Montreal & 1,351 & 93 & 12.0 & 8 & 476 \\
\hline Croatia & Zagreb & 1,212 & 40,517 & 12.0 & 3,376 & 426 \\
\hline Cyprus & Nicosia & 1,886 & 10,968 & 12.0 & 914 & 663 \\
\hline Czech Republic & Praha & 998 & 204,490 & 8.5 & 24,058 & 351 \\
\hline Denmark & Copenhagen & 989 & 57,149 & 8.0 & 7,144 & 348 \\
\hline Estonia & Tallin & 960 & 2,800 & 12.0 & 233 & 338 \\
\hline Finland & Helsinki & 948 & 12,883 & 12.0 & 1,074 & 334 \\
\hline Germany & Würzburg & 1,091 & $8,010,660$ & 11.5 & 696,579 & 378 \\
\hline Greece & Athens & 1,585 & 867,384 & 12.0 & 72,282 & 558 \\
\hline Hungary & Budapest & 1,199 & 63,287 & 10.0 & 6,329 & 422 \\
\hline Ireland & Dublin & 949 & 24,028 & 12.0 & 2,002 & 364 \\
\hline Italy & Bologna & 1,419 & 850,368 & 12.0 & 70,864 & 499 \\
\hline Japan & Tokyo & 1,175 & 136,625 & 12.0 & 11,385 & 414 \\
\hline Korea, South & Seoul & 1,161 & 20,077 & 12.0 & 1,673 & 409 \\
\hline Latvia & Riga & 991 & 2,378 & 12.0 & 198 & 349 \\
\hline Lesotho & Maseru & 2,050 & 7 & 12.0 & 1 & 721 \\
\hline Lithuania & Vilnius & 1,001 & 2,854 & 12.0 & 238 & 352 \\
\hline Luxembourg & Luxembourg & 1,037 & 11,598 & 12.0 & 966 & 365 \\
\hline Macedonia & Skopje & 1,381 & 651 & 10.0 & 65 & 486 \\
\hline Malta & Luqa & 1,902 & 9,965 & 12.0 & 830 & 669 \\
\hline Morocco & Rabat & 2,000 & 4,510 & 12.0 & 376 & 704 \\
\hline Netherlands & Amsterdam & 999 & 32,610 & 6.0 & 5,435 & 352 \\
\hline New Zealand & Wellington & 1,401 & 4,789 & 12.0 & 399 & 493 \\
\hline Norway & Oslo & 971 & 27,454 & 15.0 & 1,830 & 342 \\
\hline Palestinian Territories & Jerusalem & 2,198 & 18,349 & 12.0 & 1,529 & 773 \\
\hline Poland & Warsaw & 1,024 & 106,860 & 12.0 & 8,905 & 365 \\
\hline Romania & Bucharest & 1,324 & 33,651 & 12.0 & 2,804 & 466 \\
\hline Russia & Moscow & 996 & 1,109 & 15.0 & 74 & 350 \\
\hline Slovakia & Bratislava & 1,214 & 31,069 & 12.0 & 2,589 & 427 \\
\hline Slovenia & Ljubjana & 1,115 & 8,808 & 12.0 & 734 & 362 \\
\hline Spain & Madrid & 1,644 & 312,303 & 10.0 & 31,230 & 619 \\
\hline Sweden & Gothenburg & 934 & 292,453 & 10.0 & 29,245 & 389 \\
\hline Switzerland & Zürich & 1,094 & 337,331 & 11.0 & 30,666 & 385 \\
\hline Thailand & Bangkok & 1,765 & 1,708 & 12.0 & 142 & 621 \\
\hline United Kingdom & London & 943 & 153,931 & 12.0 & 12,828 & 332 \\
\hline \multirow[t]{3}{*}{ All other countries ( $5 \%$ ) } & & 1,140 & $1,151,503$ & 12.0 & 95,959 & 401 \\
\hline & TOTAL & & $15,039,495$ & & $1,283,315$ & \\
\hline & AVERAGE & 1,265 & & 12 & & 401 \\
\hline
\end{tabular}

combi-system: system for the supply of domestic hot water and space heating 
9.2.1 Data of the reference unglazed water collector for swimming pool heating

$\eta=0.85 \quad \mathrm{a}_{1}=20\left[\mathrm{~W} / \mathrm{m}^{2} \mathrm{~K}\right] \quad \mathrm{a}_{2}=0.1\left[\mathrm{~W} / \mathrm{m}^{2} \mathrm{~K}^{2}\right]$

9.2.2 Data of the reference collector for all other applications except for China

$$
\eta=0.8 \quad a_{1}=3.69\left[\mathrm{~W} / \mathrm{m}^{2} \mathrm{~K}\right] \quad \mathrm{a}_{2}=0.007\left[\mathrm{~W} / \mathrm{m}^{2} \mathrm{~K}^{2}\right]
$$

9.2.3 Data of the Chinese reference vacuum tube collector

$$
\eta=0.74 \quad a_{1}=2.5\left[\mathrm{~W} / \mathrm{m}^{2} \mathrm{~K}\right] \quad \mathrm{a}_{2}=0.013\left[\mathrm{~W} / \mathrm{m}^{2} \mathrm{~K}^{2}\right]
$$

9.3 Methodological approach for the cost calculation

The economic performance of the investigated solar thermal systems in Chapter 8 is quantified using the levelized cost of energy (LCOE) approach (e.g., acc. to $/{ }^{31} /$ ). The idea of this approach is to compare the total costs (C) related to an energy supply system with the resulting energy supplied by this system (E). Since both the costs as well as the energy supplied are subject to the time preference of the investors, both terms are discounted at the interest rate $r$ with an economic assessment period of $t$. LCOE are calculated according to Eq. 1:

$L C O E=\frac{\sum_{t=1}^{t_{\text {ges }}} C_{t} \cdot(1+r)^{-t}}{\sum_{t=1}^{t_{\text {ges }}} E_{t} \cdot(1+r)^{-t}}$

The calculation of levelized cost of solar thermal generated heat $\mathrm{LCOH}$ in this reportis derived from Equation 1 and may be expressed as the following:

$L C O E=\frac{I_{0}+\sum_{t=1}^{t_{\text {ges }}} A_{t} \cdot(1+r)^{-t}}{\sum_{t=1}^{t_{\text {ges }}} S E \cdot(1+r)^{-t}} \quad$ (Eq. 2)

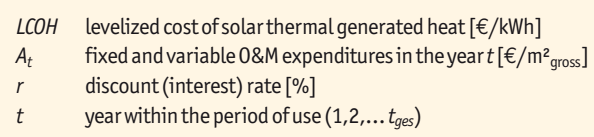

$\begin{array}{ll}I_{0} & \text { specific solar thermal system costs incl. installation (excl. VAT and subsidies) }\left[€ / \mathrm{m}^{2} \text { gross }\right] \\ S E & \text { solar energy yield in theyear } t\left[\mathrm{kWh} / \mathrm{m}^{2} \text { gross }\right] \\ t_{\text {ges }} & \text { period of use (solar thermal system life time in years) [a] }\end{array}$

All technical and economical parameters of the investigated solar thermal systems are elaborated for both the solar loop and solar energy storage. Conventional heat supply is not considered.

All specific benchmark figures are referred to gross collector area installed (e.g., € $/ \mathrm{m}^{2}$ gross, $\mathrm{kWh} / \mathrm{m}^{2}$ gross).

Cost data refer to end-user (customer) prices excluding value added taxes or subsidies. Solar energy yield SE is referred to as specific annual thermal energy delivered by the solar thermal collector in $\mathrm{kWh}$ per $\mathrm{m}^{2}$ gross collector area installed (thermal losses in solar loop piping and thermal energy storage not considered).

Calculation of levelized cost of solar thermal generated heat $\mathrm{LCOH}$ in this report is based on following assumptions for all systems:

- Discount (interest) rate $r=3 \%$

- Annual $0 \& M$ expenditures $A_{t}=0.5 \%$ of specific costs incl. installation $I_{0}$ in case of pumped systems

- Annual $0 \&$ M expenditures $A_{t}=0.25 \%$ of specific costs incl. installation $I_{0}$ in case of thermosiphon systems 
- Period of use (solar thermal system life time) $t_{\text {ges }}=25$ years for all pumped systems (except China: 15 years) and 10 years for all thermosiphon systems (except Australia: 15 years).

In Table 12, techno-economic benchmark figures of the investigated solar thermal systems are summarized for all countries and all kinds of applications.

\begin{tabular}{|c|c|c|c|c|c|c|c|c|c|}
\hline \multirow{3}{*}{$\begin{array}{l}\text { Country } \\
\qquad[-]\end{array}$} & \multirow{3}{*}{$\begin{array}{c}\text { Type of system } \\
\text { [-] }\end{array}$} & \multirow{3}{*}{$\begin{array}{c}\begin{array}{c}\text { Global } \\
\text { horizontal } \\
\text { irradiation }\end{array} \\
\mathrm{kWh} /\left(\mathrm{m}^{2} \cdot \mathrm{a}\right)\end{array}$} & \multirow{3}{*}{$\begin{array}{l}\text { Kind of sys- } \\
\text { tem / Kind of } \\
\text { collector } \\
{[-]}\end{array}$} & \multirow{3}{*}{$\begin{array}{c}\text { Gross coll. area / } \\
\text { storage volume } \\
\qquad \mathrm{m}^{2} / \text { liter }\end{array}$} & \multirow{3}{*}{$\begin{array}{c}\text { Annual } \\
\text { solar energy } \\
\text { yield* }\end{array}$} & \multicolumn{2}{|c|}{$\begin{array}{l}\text { Net spec. solar } \\
\text { thermal system } \\
\text { costs incl. labour }\end{array}$} & \multicolumn{2}{|c|}{$\begin{array}{l}\text { Levelized cost } \\
\text { of heat }\end{array}$} \\
\hline & & & & & & MIN & MAX & MIN & MAX \\
\hline & & & & & & \multicolumn{2}{|c|}{$€ /\left(m^{2}\right.$ gross $)$} & \multicolumn{2}{|c|}{$€-\mathrm{ct} / \mathrm{kWh}$} \\
\hline \multicolumn{10}{|c|}{ Economies of Scale - Example Denmark (Figure 57) } \\
\hline Denmark & DHW-SFH & 989 & PS/FPC & $4.0 \mathrm{~m}^{2} / 200$ ltr. & 454 & 880 & 1,320 & 12.9 & 19.4 \\
\hline Denmark & COMBI-SFH & 989 & PS / FPC & $7.0 \mathrm{~m}^{2} / 300$ ltr. & 348 & 776 & 1,164 & 14.8 & 22.2 \\
\hline Denmark & DHW-MFH & 989 & PS / FPC & $50 \mathrm{~m}^{2} / 2,500$ ltr. & 414 & 600 & 900 & 9.7 & 14.5 \\
\hline Denmark & $\begin{array}{l}\text { SDH (diurnal } \\
\text { storage) }\end{array}$ & 989 & PS / FPC & $\begin{array}{c}10.000 \mathrm{~m}^{2} / \\
1.150 \mathrm{~m}^{3}\end{array}$ & 451 & 211 & 269 & 3.2 & 4.1 \\
\hline Denmark & $\begin{array}{l}\text { SDH (seasonal } \\
\text { storage) }\end{array}$ & 989 & PS / FPC & $50.000 \mathrm{~m}^{2} / 125,000 \mathrm{~m}^{3}$ & 402 & 247 & 334 & 4.2 & 5.7 \\
\hline Country & $\begin{array}{l}\text { Reference } \\
\text { climate }\end{array}$ & $\begin{array}{c}\text { Global } \\
\text { horizontal } \\
\text { irradiation }\end{array}$ & $\begin{array}{l}\text { Kind of sys- } \\
\text { tem / Kind of } \\
\text { collector }\end{array}$ & $\begin{array}{c}\text { Gross coll. } \\
\text { area / storage volume }\end{array}$ & $\begin{array}{c}\text { Annual } \\
\text { solar energy } \\
\text { yield* }\end{array}$ & \multicolumn{2}{|c|}{$\begin{array}{l}\text { Net spec. solar } \\
\text { thermal system } \\
\text { costs incl. labour }\end{array}$} & \multicolumn{2}{|c|}{$\begin{array}{l}\text { Levelized Cost } \\
\text { of Heat }\end{array}$} \\
\hline \multirow{2}{*}[-]{} & \multirow{2}{*}[-]{} & \multirow{2}{*}{$\mathrm{kWh} /\left(\mathrm{m}^{2} \cdot \mathrm{a}\right)$} & \multirow{2}{*}[-]{} & \multirow{2}{*}{$\mathrm{m}^{2} /$ liter } & $\mathrm{kWh} /\left(\mathrm{m}^{2} \cdot \mathrm{a}\right)$ & MIN & MAX & MIN & MAX \\
\hline & & & & & $\operatorname{kWM} /\left(\mathrm{II}^{2} \cdot \mathrm{d}\right)$ & $€ /\left(\mathrm{m}^{2}\right.$ & oss) & $€-c$ & Wh \\
\hline Small domest & hot water systems ( & g. in single far & ily homes) - A) Pur & mped systems (Figure 58) & & & & & \\
\hline Australia-1 & Sydney & 1,674 & PS / FPC & $3.9 \mathrm{~m}^{2} / 250$ ltr. & 844 & 740 & 1,200 & 5.9 & 9.6 \\
\hline Australia-2 & Sydney & 1,674 & PS / ETC & $4.1 \mathrm{~m}^{2} / 290$ ltr. & 844 & 990 & 1,320 & 10.7 & 14.3 \\
\hline Austria & Graz & 1,126 & PS / FPC & $6.0 \mathrm{~m}^{2} / 300$ ltr. & 451 & 840 & 1,100 & 12.5 & 16.2 \\
\hline Canada & Montreal & 1,351 & PS/FPC & $6.0 \mathrm{~m}^{2} / 300$ ltr. & 556 & 800 & 1,200 & 9.6 & 14.5 \\
\hline China-2 & Shanghai & 1,282 & PS / ETC & $3.0 \mathrm{~m}^{2} / 200$ ltr. & 592 & 240 & 470 & 5.4 & 10.6 \\
\hline China-3 & Shanghai & 1,282 & PS/FPC & $2.2 \mathrm{~m}^{2} / 120$ ltr. & 592 & 320 & 560 & 5.2 & 9.0 \\
\hline Denmark & Copenhagen & 989 & PS / FPC & $4.0 \mathrm{~m}^{2} / 200$ ltr. & 454 & 880 & 1,320 & 12.9 & 19.4 \\
\hline Germany & Wurzburg & 1,091 & PS/FPC & $6.0 \mathrm{~m}^{2} / 300$ ltr. & 424 & 440 & 1,210 & 7.8 & 20.6 \\
\hline France & Paris & 1,112 & PS/FPC & $3.2 \mathrm{~m}^{2} / 200$ ltr. & 496 & 1,180 & 1,760 & 15.9 & 23.8 \\
\hline Small domest & hot water systems ( & g. in single far & ily homes) - B) Th & ermosiphon systems (Figur & re 59) & & & & \\
\hline Australia-3 & Sydney & 1,674 & TS/FPC & $3.9 \mathrm{~m}^{2} / 280$ ltr. & 844 & 930 & 1,240 & 10.4 & 13.9 \\
\hline Brazil & Brasília & 1,793 & TS / FPC & $3.4 \mathrm{~m}^{2} / 400$ ltr. & 809 & 190 & 280 & 3.0 & 4.6 \\
\hline China-1 & Shanghai & 1,282 & TS/ETC & $3.0 \mathrm{~m}^{2} / 200$ ltr. & 592 & 160 & 310 & 4.9 & 9.5 \\
\hline India & New-Delhi & 1,961 & TS / FPC & $4.0 \mathrm{~m}^{2} / 250$ ltr. & 882 & 220 & 320 & 3.2 & 4.8 \\
\hline Israel & Jerusalem & 2,198 & TS/FPC & $2.0 \mathrm{~m}^{2} / 150$ ltr. & 1,024 & 330 & 500 & 4.2 & 6.4 \\
\hline South Africa & Johannesbg. & 2,075 & TS/FPC & $4.0 \mathrm{~m}^{2} / 300$ ltr. & 1,009 & 490 & 900 & 6.4 & 11.8 \\
\hline Turkey & Antalya & 1,795 & TS/FPC & $4.0 \mathrm{~m}^{2} / 170$ trr. & 910 & 110 & 180 & 1.6 & 2.6 \\
\hline Large domest & hot water and/or sp & ace heating syst & ems (e.g. in multif & amily homes, hotels, etc.) & (Figure 60) & & & & \\
\hline Austria & Graz & 1,126 & PS / FPC & $50 \mathrm{~m}^{2} / 4000$ ltr. & 505 & 530 & 830 & 7.0 & 11.1 \\
\hline Brazil & Brasília & 1,793 & PS / FPC & $50 \mathrm{~m}^{2} / 4000$ ltr. & 658 & 190 & 290 & 2.0 & 3.0 \\
\hline Canada & Montreal & 1,351 & PS / FPC & $44 \mathrm{~m}^{2} / 1350$ ltr. & 621 & 680 & 1,020 & 7.4 & 11.1 \\
\hline China-1 & Shanghai & 1,282 & PS / ETC & $50 \mathrm{~m}^{2} / 3000$ ltr. & 502 & 240 & 510 & 6.2 & 13.5 \\
\hline China-2 & Shanghai & 1,282 & PS / FPC & $50 \mathrm{~m}^{2} / 2500$ ltr. & 502 & 190 & 420 & 3.7 & 8.1 \\
\hline Denmark & Copenhagen & 989 & $\mathrm{PS} / \mathrm{FPC}$ & $50 \mathrm{~m}^{2} / 2500$ ltr. & 414 & 600 & 900 & 9.7 & 14.5 \\
\hline France & Paris & 1,112 & PS / FPC & $20 \mathrm{~m}^{2} / 1000$ ltr. & 489 & 900 & 1,240 & 12.5 & 17.1 \\
\hline India & New-Delhi & 1,961 & PS/FPC & $50 \mathrm{~m}^{2} / 3125$ ltr. & 749 & 140 & 280 & 1.3 & 2.5 \\
\hline South Africa & Johannesbg. & 2,075 & PS/FPC & $75 \mathrm{~m}^{2} / 6000$ ltr. & 867 & 540 & 830 & 4.2 & 6.5 \\
\hline Combined hot & later and space heat & ing systems (Fic & ure 61) & & & & & & \\
\hline Austria & Graz & 1,126 & PS / FPC & $16 \mathrm{~m}^{2} / 1500$ ltr. & 369 & 670 & 890 & 12.4 & 16.2 \\
\hline Brazil & Belo Horizonte & 1,789 & PS / FPC & $30 \mathrm{~m}^{2} / 3500$ ltr. & 631 & 190 & 290 & 2.1 & 3.1 \\
\hline China-1 & Shanghai & 1,282 & PS/ETC & $3 \mathrm{~m}^{2} / 200$ ltr. & 388 & 240 & 450 & 8.2 & 15.5 \\
\hline China-2 & Shanghai & 1,282 & PS / FPC & $2.2 \mathrm{~m}^{2} / 120$ ltr. & 388 & 320 & 560 & 8.1 & 14.1 \\
\hline Denmark & Copenhagen & 989 & PS / FPC & $7 \mathrm{~m}^{2} / 300$ ltr. & 348 & 780 & 1,160 & 14.8 & 22.2 \\
\hline Germany & Wurzburg & 1,091 & PS / FPC & $12 \mathrm{~m}^{2} / 1000$ ltr. & 378 & 410 & 1,180 & 8.1 & 22.6 \\
\hline South Africa & Johannesbg. & 2,075 & PS / FPC & $55 \mathrm{~m}^{2} / 2000$ ltr. & 730 & 1,060 & 1,370 & 9.9 & 12.7 \\
\hline Pool heating s & stems with unglaze & water collector & (Figure 62) & & & & & & \\
\hline Australia & Sydney & 1,674 & PS/ unglazed & $34 m^{2} /-$ & 466 & 40 & 80 & 0.5 & 1.0 \\
\hline Brazil & Belo Horiz. & 1,789 & PS/ unglazed & $36 m^{2} /-$ & 375 & 20 & 40 & 0.3 & 0.6 \\
\hline Canada & Montreal & 1,351 & PS/ unglazed & $24 \mathrm{~m}^{2} /-$ & 386 & 90 & 160 & 1.4 & 2.6 \\
\hline Israel & Jerusalem & 2,198 & PS/ unglazed & $480 \mathrm{~m}^{2} /-$ & 568 & 130 & 260 & 1.4 & 2.9 \\
\hline
\end{tabular}

* Annual solar energy yields in Table 12 are referred to aperture collector area. For LCOH calculation annual solar energy yields referring to gross collector area were used (conversion factors of 1 / 1.1 for flat plate collectors and 1 / 1.5 for evacuated tube collectors were assumed)

Table 12: $\quad$ Country-specific techno-economic benchmark figures of the investigated solar thermal systems 


\section{4 \\ Methodological approach for job the calculation}

The job calculation is based on a comprehensive literature study, information provided by the China National Renewable Energy Centre and IRENA as well as data collected from different country market reports. Based on this information the following assumptions were taken to calculate the number of full time jobs:

In countries with high labor cost, advanced automated production of flat plate or evacuated tube collectors and heat storages pumped systems with a total of $133 \mathrm{~m}^{2}$ solar collector area have to be installed on average per full time job. In countries with low labor cost and advanced automated production of evacuated tube collectors and heat storages - thermosiphon systems with a total of $87 \mathrm{~m}^{2}$ solar collector area have to be installed per full timejob on average. The same collector area has to be installed per full time job in countries with mainly manual flat plate collector production and low labor cost. For swimming pool systems with unglazed polymeric collectors or air collectors around $200 \mathrm{~m}^{2}$ solar collector area have to be installed per full time job.

The numbers presented are full time jobs and consider production, installation and maintenance of solar thermal systems.

$9.5 \quad$ Reference climates

\begin{tabular}{|c|c|c|c|c|c|}
\hline No. & Country & Reference climate & $\begin{array}{c}\text { Horizontal irradiation } \\
{\left[\mathrm{kWh} / \mathrm{m}^{2} \cdot \mathrm{a}\right]}\end{array}$ & $\begin{array}{c}\text { Inclined irradiation } \\
{\left[\mathrm{kWh} / \mathrm{m}^{2} \cdot \mathrm{a}\right]}\end{array}$ & $\begin{array}{c}\text { Avg. outside air temp. } \\
{\left[{ }^{\circ} \mathrm{C}\right]}\end{array}$ \\
\hline 2 & Australia & Sydney & 1,674 & 1,841 & 18.1 \\
\hline 4 & Barbados & Grantley Adams & 2,016 & 2,048 & 27.4 \\
\hline 5 & Belgium & Brussels & 971 & 1,095 & 10.0 \\
\hline 6 & Botswana & Gaborone & 2,161 & 2,365 & 18.0 \\
\hline 7 & Brazil & Brasília & 1,793 & 1,838 & 22.0 \\
\hline 10 & Canada & Montreal & 1,351 & 1,568 & 6.9 \\
\hline 11 & Chile & Santiago de Chile & 1,753 & 1,850 & 14.5 \\
\hline 12 & China & Shanghai & 1,282 & 1,343 & 17.1 \\
\hline 13 & Croatia & Zagreb & 1,212 & 1,352 & 11.3 \\
\hline 14 & Cyprus & Nicosia & 1,886 & 2,098 & 19.9 \\
\hline 15 & Czech Republic & Praha & 998 & 1,111 & 7.9 \\
\hline 20 & Germany & Würzburg & 1,091 & 1,225 & 9.5 \\
\hline 21 & Ghana & Accra & 2,146 & 2,161 & 23.7 \\
\hline 22 & Greece & Athens & 1,585 & 1,744 & 18.5 \\
\hline 23 & Hungary & Budapest & 1,199 & 1,346 & 11.0 \\
\hline 24 & India & Neu-Delhi & 1,961 & 2,275 & 24.7 \\
\hline 25 & Ireland & Dublin & 949 & 1,091 & 9.5 \\
\hline 26 & Israel & Jerusalem & 2,198 & 2,400 & 17.3 \\
\hline 27 & Italy & Bologna & 1,419 & 1,592 & 14.3 \\
\hline 28 & Japan & Tokyo & 1,175 & 1,287 & 16.7 \\
\hline 29 & Jordan & Amman & 2,145 & 2,341 & 17.9 \\
\hline 30 & Korea, South & Seoul & 1,161 & 1,280 & 12.7 \\
\hline 31 & Latvia & Riga & 991 & 1,187 & 6.3 \\
\hline 41 & Mozambique & Maputo & 1,910 & 2,100 & 22.8 \\
\hline 42 & Namibia & Windhoek & 2,363 & 2,499 & 21.0 \\
\hline
\end{tabular}




\begin{tabular}{|c|c|c|c|c|c|}
\hline \multirow{2}{*}{ No. } & \multirow{2}{*}{ Country } & \multirow{2}{*}{ Reference climate } & Horizontal irradiation & Inclined irradiation & Avg. outside air temp. \\
\hline & & & {$\left[\mathrm{kWh} / \mathrm{m}^{2} \cdot \mathrm{a}\right]$} & {$\left[\mathrm{kWh} / \mathrm{m}^{2} \cdot \mathrm{a}\right]$} & {$\left[{ }^{\circ} \mathrm{C}\right]$} \\
\hline 43 & Netherlands & Amsterdam & 999 & 1,131 & 10.0 \\
\hline 44 & New Zealand & Wellington & 1,401 & 1,542 & 13.6 \\
\hline 45 & Nigeria & Abuja & 2,007 & 2,051 & 25.7 \\
\hline 46 & Norway & Oslo & 971 & 1,208 & 5.8 \\
\hline 47 & Palestinian Territories & Jerusalem & 2,198 & 2,400 & 17.3 \\
\hline 48 & Poland & Warsaw & 1,024 & 1,156 & 8.1 \\
\hline 49 & Portugal & Lisbon & 1,686 & 1,875 & 17.4 \\
\hline 50 & Romania & Bucharest & 1,324 & 1,473 & 10.6 \\
\hline 51 & Russia & Moscow & 996 & 1,181 & 5.9 \\
\hline 52 & Senegal & Dakar & 2,197 & 2,259 & 24.9 \\
\hline 53 & Slovakia & Bratislava & 1,214 & 1,374 & 10.3 \\
\hline 54 & Slovenia & Ljubjana & 1,115 & 1,231 & 9.8 \\
\hline 55 & South Africa & Johannesburg & 2,075 & 2,232 & 15.6 \\
\hline 56 & Spain & Madrid & 1,644 & 1,844 & 15.5 \\
\hline 57 & Sweden & Gothenburg & 934 & 1,105 & 7.2 \\
\hline 58 & Switzerland & Zürich & 1,094 & 1,218 & 9.6 \\
\hline 59 & Taiwan & Taipei & 1,372 & 1,398 & 20.8 \\
\hline 60 & Thailand & Bangkok & 1,765 & 1,898 & 29.1 \\
\hline 61 & Tunisia & Tunis & 1,808 & 2,038 & 19.3 \\
\hline 62 & Turkey & Antalya & 1,795 & 1,958 & 18.4 \\
\hline 63 & United Kingdom & London & 943 & 1,062 & 12.0 \\
\hline 64 & United States & LA, Indianapolis & 1,646 & 1,816 & 14.3 \\
\hline 65 & Uruguay & Montevideo & 1,534 & 1,647 & 15.9 \\
\hline 66 & Zimbabwe & Harare & 2,017 & 2,087 & 18.9 \\
\hline
\end{tabular}

Source: T-Sol expertversion 4.5 and Meteonorm version 6.1.

Table 13: $\quad$ Reference climates for the 66 countries surveyed

\begin{tabular}{|r|l|c|c|}
\hline No & Country & $\mathbf{2 0 1 6}$ & $\begin{array}{c}\text { Reg. } \\
\text { code }\end{array}$ \\
\hline 1 & Albania & $3,038,594$ & 6 \\
\hline 2 & Australia & $22,992,654$ & 3 \\
\hline 3 & Austria & $8,711,770$ & 6 \\
\hline 4 & Barbados & 291,495 & 4 \\
\hline 5 & Belgium & $11,409,477$ & 6 \\
\hline 7 & Botswana & $2,180,597$ & 1 \\
\hline 8 & Bulgaria & $205,823,665$ & 4 \\
\hline 9 & Burkina Faso & $7,144,653$ & 6 \\
\hline 10 & Canada & $19,512,533$ & 1 \\
\hline 11 & Chile & $35,362,905$ & 8 \\
\hline 12 & China & $17,650,114$ & 4 \\
\hline 13 & Croatia & $1,373,541,278$ & 5 \\
\hline 14 & Cyprus & $4,313,707$ & 6 \\
\hline 15 & Czech Republic & $1,205,575$ & 6 \\
\hline 16 & Denmark & $10,660,932$ & 6 \\
\hline 17 & Estonia & $5,593,785$ & 6 \\
\hline 18 & Finland & $1,258,545$ & 6 \\
\hline 19 & France & $5,498,211$ & 6 \\
\hline 20 & Germany & $66,836,154$ & 6 \\
\hline 21 & Ghana & $80,722,792$ & 6 \\
\hline 22 & Greece & $26,908,262$ & 1 \\
\hline 23 & Hungary & $10,773,253$ & 6 \\
\hline 24 & India & $9,874,784$ & 6 \\
\hline 25 & Ireland & $1,266,883,598$ & 2 \\
\hline 26 & Israel & $4,952,473$ & 6 \\
\hline 27 & Italy & $8,174,527$ & 7 \\
\hline 28 & Japan & $62,007,540$ & 6 \\
\hline 29 & Jordan & $126,702,133$ & 2 \\
\hline 30 & Korea, South & $10,041,098$ & 7 \\
\hline 31 & Latvia & $50,924,172$ & 2 \\
\hline 32 & Lebanon & $1,965,686$ & 6 \\
\hline 33 & Lesotho & $6,237,738$ & 7 \\
\hline 34 & Lithuania & $1,953,070$ & 1 \\
\hline 35 & Luxembourg & $2,854,235$ & 6 \\
\hline 36 & Macedonia & 582,291 & 6 \\
\hline & & & 6 \\
\hline
\end{tabular}

\begin{tabular}{|c|l|c|c|}
\hline No & Country & $\mathbf{2 0 1 6}$ & $\begin{array}{c}\text { Reg. } \\
\text { code }\end{array}$ \\
\hline 37 & Malta & 415,196 & 6 \\
\hline 38 & Mauritius & $1,348,242$ & 1 \\
\hline 39 & Mexico & $123,166,749$ & 4 \\
\hline 40 & Morocco & $33,655,786$ & 7 \\
\hline 41 & Mozambique & $25,930,150$ & 1 \\
\hline 42 & Namibia & $2,436,469$ & 1 \\
\hline 43 & Netherlands & $17,016,967$ & 6 \\
\hline 44 & NewZealand & $4,474,549$ & 3 \\
\hline 45 & Nigeria & $186,053,386$ & 1 \\
\hline 46 & Norway & $5,265,158$ & 6 \\
\hline 47 & Palestinian Territories & $4,451,014$ & 7 \\
\hline 48 & Poland & $38,523,261$ & 6 \\
\hline 49 & Portugal & $10,833,816$ & 6 \\
\hline 50 & Romania & $21,599,736$ & 6 \\
\hline 51 & Russia & $142,355,415$ & 6 \\
\hline 52 & Senegal & $14,320,055$ & 1 \\
\hline 53 & Slovakia & $5,445,802$ & 6 \\
\hline 54 & Slovenia & $1,978,029$ & 6 \\
\hline 55 & South Africa & $54,300,704$ & 1 \\
\hline 56 & Spain & $48,563,476$ & 6 \\
\hline 57 & Sweden & $9,880,604$ & 6 \\
\hline 58 & Switzerland & $8,179,294$ & 6 \\
\hline 59 & Taiwan & $23,464,787$ & 2 \\
\hline 60 & Thailand & $68,200,824$ & 2 \\
\hline 61 & Tunisia & $11,285,452$ & 7 \\
\hline 62 & Turkey & $80,274,604$ & 6 \\
\hline 63 & United Kingdom & $64,430,428$ & 6 \\
\hline 64 & United States & $323,127,513$ & 8 \\
\hline 65 & Uruguay & $3,351,016$ & 4 \\
\hline 66 & Zimbabwe & $13,600,580$ & 1 \\
\hline & All other countries & $2,501,383,326$ & 9 \\
\hline & & $4,824,613,383$ & $66 \%$ \\
\hline $\mathbf{5}$ Solar Thermal World & $7,325,996,709$ & $100 \%$ \\
\hline Statistics & & \\
\hline $\mathbf{I n}$ Inhabitants world & & \\
\hline & & & \\
\hline
\end{tabular}

Data source: International Data Base of the U.S. Census Bureau http://www.census.gov/ipc/www/idb/country.php

Table 14: $\quad$ Inhabitants by the end of 2016 of the 66 surveyed countries in alphabetical order 


\begin{tabular}{|c|c|c|c|}
\hline \multicolumn{2}{|c|}{ Region Code / Region } & $\Sigma$ Inhabitants 2016 & Share 2016 \\
\hline 1 & Sub-Sahara Africa & $348,544,048$ & $5 \%$ \\
\hline 2 & Asia excl. China & $1,536,175,514$ & $21 \%$ \\
\hline 3 & Australia / New Zealand & $27,467,203$ & $0 \%$ \\
\hline 4 & Latin America & $350,283,039$ & $5 \%$ \\
\hline 5 & China & $1,373,541,278$ & $19 \%$ \\
\hline 6 & Europe & $756,266,268$ & $10 \%$ \\
\hline 7 & MENA Region & $73,845,615$ & $1 \%$ \\
\hline 8 & United States / Canada & $358,490,418$ & $5 \%$ \\
\hline & Other countries & $2,501,383,326$ & $34 \%$ \\
\hline \multicolumn{2}{|c|}{ TOTAL } & $7,325,996,709$ & $100 \%$ \\
\hline
\end{tabular}

Sub-Sahara Africa: $\quad$ Botswana, Burkina Faso, Ghana, Namibia, Nigeria, Mozambique, Senegal, South Africa, Zimbabwe

Asia excluding China: India, Japan, Korea South, Taiwan, Thailand

Latin America: $\quad$ Barbados, Brazil, Chile, Mexico, Uruguay

Europe: $\quad$ Albania, EU 28, Macedonia, Norway, Russia, Switzerland, Turkey

MENA countries: $\quad$ Israel, Jordan, Lebanon, Morocco, Palestinian Territories, Tunisia

Data source:International Data Base of the U.S. Census Bureau http://www.census.gov/ipc/www/idb/country.php

Table 15: $\quad$ Inhabitants per economic region by the end of 2016

\section{Market data of the previous years}

The data presented in Chapters $\mathbf{5}$ to $\mathbf{8}$ were originally collected in square meters. Through an agreement of international experts the collector areas of these solar thermal applications have been converted and are shown in installed capacity as well.

Making the installed capacity of solar thermal collectors comparable with that of other energy sources, solar thermal experts from seven countries agreed upon a methodology to convert installed collector area into solar thermal capacity.

The methodology was developed during a meeting with IEA SHC Programme officials and major solar thermal trade associations in Gleisdorf, Austria in September 2004. The represented associations from Austria, Canada, Germany, the Netherlands, Sweden and the United States as well as the European SolarThermal Industry Federation (ESTIF) and theIEA SHC Programme agreed to use a factor of $0.7 \mathrm{~kW}_{\mathrm{th}} / \mathrm{m}^{2}$ to derive the nominal capacity from the area of installed collectors.

In order to ensure consistency of the calculations within this report the following tables provide data from the previous years. If necessary, the numbers have been revised in 2018 compared to the data originally published in earlier editions of this report due to changes in methodology or the origin of the data for each country.

In the following Table 16, Table 17 and Table 18 these countries are marked accordingly and in Chapter 9.8 (References) the respective data source is cited. 


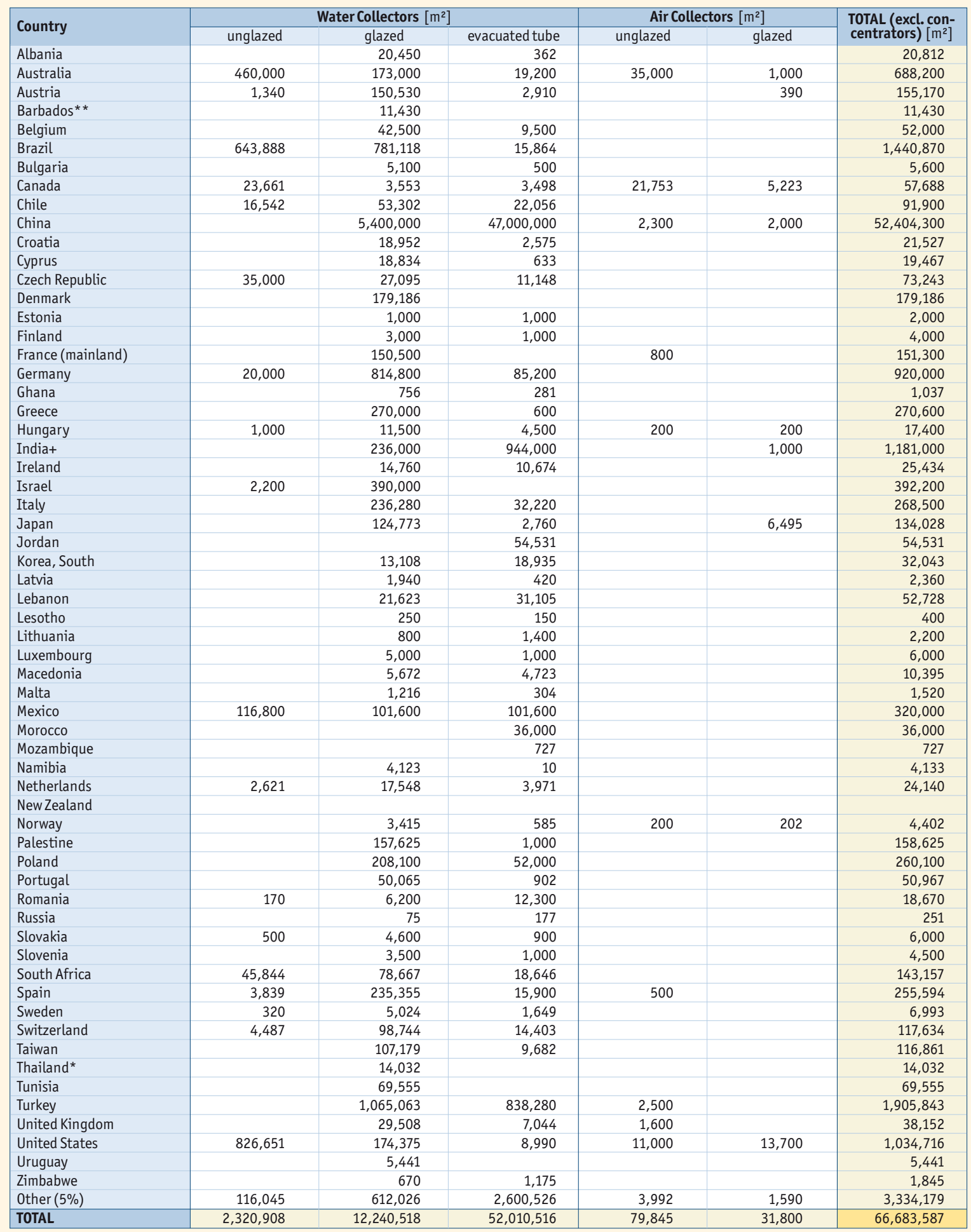

* Revised due to new/adapted database in 2018.

* * Based on Solar Water Heating Techscope Market Readiness Assessment-Reports UNEP 2015.

+ The figures for India refer to the fiscalyear April 2014 to March 2015.

Table 16: $\quad$ Newly installed collector area in $2014\left[\mathrm{~m}^{2}\right]$ 


\begin{tabular}{|c|c|c|c|c|c|c|}
\hline \multirow{2}{*}{ Country } & \multicolumn{3}{|c|}{ Water Collectors [ $\left.\mathrm{m}^{2}\right]$} & \multicolumn{2}{|c|}{ Air Collectors $\left[\mathrm{m}^{2}\right]$} & \multirow{2}{*}{$\begin{array}{l}\text { TOTAL (excl. con- } \\
\text { centrators) }\left[\mathrm{m}^{2}\right]\end{array}$} \\
\hline & unglazed & glazed & evacuated tube & unglazed & glazed & \\
\hline Albania & & 20,574 & 544 & & & 21,118 \\
\hline Australia & 400,000 & 169,000 & 18,700 & 30,000 & 1,000 & 618,700 \\
\hline Austria & 890 & 134,260 & 2,320 & & 270 & 137,740 \\
\hline Barbados** & & 11,430 & & & & 11,430 \\
\hline Belgium & & 38,250 & 6,750 & & & 45,000 \\
\hline Botswana & & 2,500 & & & & 2,500 \\
\hline Brazil & 610,066 & 767,311 & 25,055 & & & $1,402,432$ \\
\hline Bulgaria & & 5,100 & 500 & & & 5,600 \\
\hline Burkina Faso & & 932 & 139 & & & 1,070 \\
\hline Canada & 22,593 & 2,684 & 3,384 & 14,583 & 13,981 & 57,225 \\
\hline Chile & 10,045 & 25,114 & 10,502 & 0 & 80 & 45,741 \\
\hline China & & $5,500,000$ & $38,000,000$ & 200 & & $43,500,200$ \\
\hline Croatia & & 19,000 & 2,500 & & & 21,500 \\
\hline Cyprus & & 18,800 & 600 & & & 19,400 \\
\hline Czech Republic & 30,000 & 22,000 & 9,000 & & & 61,000 \\
\hline Denmark & & 250,000 & & 1,000 & & 251,000 \\
\hline Estonia & & 1,000 & 1,000 & & & 2,000 \\
\hline Finland & & 3,300 & 1,700 & & & 5,000 \\
\hline France (mainland) & 2,000 & 91,600 & 4,850 & 700 & & 99,150 \\
\hline Germany & 25,000 & 731,000 & 75,000 & & & 831,000 \\
\hline Ghana & & 76 & 24 & & & 100 \\
\hline Greece & & 271,000 & 600 & & & 271,600 \\
\hline Hungary & 1,000 & 11,000 & 4,000 & 150 & 150 & 16,300 \\
\hline India+ & & 172,267 & $1,379,550$ & & 1,000 & $1,552,817$ \\
\hline Ireland & & 12,716 & 9,951 & & & 22,667 \\
\hline Israel & 1,000 & 428,350 & & & & 429,350 \\
\hline Italy & & 201,810 & 27,520 & & & 229,330 \\
\hline Japan & & 98,608 & 2,163 & & 6,435 & 107,206 \\
\hline Korea, South & & 9,888 & 19,145 & & & 29,033 \\
\hline Latvia & & 1,580 & 330 & & & 1,910 \\
\hline Lebanon & & 21,348 & 32,628 & & & 53,976 \\
\hline Lesotho & & 70 & 140 & & & 210 \\
\hline Lithuania & & 800 & 1,400 & & & 2,200 \\
\hline Luxembourg & & 4,700 & 750 & & & 5,450 \\
\hline Macedonia & & 5,955 & 4,936 & & & 10,891 \\
\hline Malta & & 800 & 200 & & & 1,000 \\
\hline Mexico & 104,000 & 130,000 & 111,000 & & & 345,000 \\
\hline Mozambique & 136 & 48 & 32 & & & 216 \\
\hline Namibia & 780 & 4,802 & 3 & & & 5,585 \\
\hline Netherlands & 2,621 & 17,548 & 3,971 & & & 24,140 \\
\hline Nigeria & & 58 & 90 & & 35 & 184 \\
\hline Norway & & 0 & 3,415 & & & 3,415 \\
\hline Palestine & & 49,000 & 225 & & & 49,225 \\
\hline Poland & & 225,000 & 52,000 & & & 277,000 \\
\hline Portugal & & 45,304 & 830 & & & 46,134 \\
\hline Romania & 170 & 6,800 & 11,000 & & & 17,970 \\
\hline Russia & & 716 & 32 & & & 748 \\
\hline Senegal & & 4 & 80 & & 55 & 139 \\
\hline Slovakia & 500 & 4,500 & 800 & & & 5,800 \\
\hline Slovenia & & 2,200 & 600 & & & 2,800 \\
\hline South Africa & 78,940 & 29,016 & 24,000 & & & 131,956 \\
\hline Spain & 3,375 & 226,669 & 11,121 & & & 241,165 \\
\hline Sweden & 82 & 5,036 & 1,535 & & & 6,653 \\
\hline Switzerland & 6,676 & 76,275 & 15,485 & & & 98,436 \\
\hline Taiwan & & 119,015 & 8,969 & & & 127,985 \\
\hline Thailand* & & 6,700 & & & & 6,700 \\
\hline Tunisia & & 63,223 & & & & 63,223 \\
\hline Turkey & & $1,071,070$ & $1,024,665$ & 1,000 & & $2,096,735$ \\
\hline United Kingdom & & 20,322 & 3,967 & 500 & & 24,789 \\
\hline United States & 835,744 & 162,189 & 8,361 & 10,500 & 11,000 & $1,027,794$ \\
\hline Uruguay & & 6,003 & & & & 6,003 \\
\hline Zimbabwe & & 353 & 2,898 & & & 3,251 \\
\hline Other (5\%) & 112,401 & 596,141 & $2,154,261$ & 3,086 & 1,790 & $2,867,678$ \\
\hline TOTAL & $2,248,019$ & $11,922,813$ & $43,085,223$ & 61,719 & 35,795 & $57,353,569$ \\
\hline
\end{tabular}

* Revised due to new/adapted database in 2018.

** Based on Solar Water Heating Techscope Market Readiness Assessment-Reports UNEP 2015.

$+\quad$ The figures for India refer to the fiscalyear April 2015 to March 2016.

Table 17: $\quad$ Newly installed collector area in $2015\left[\mathrm{~m}^{2}\right]$ 


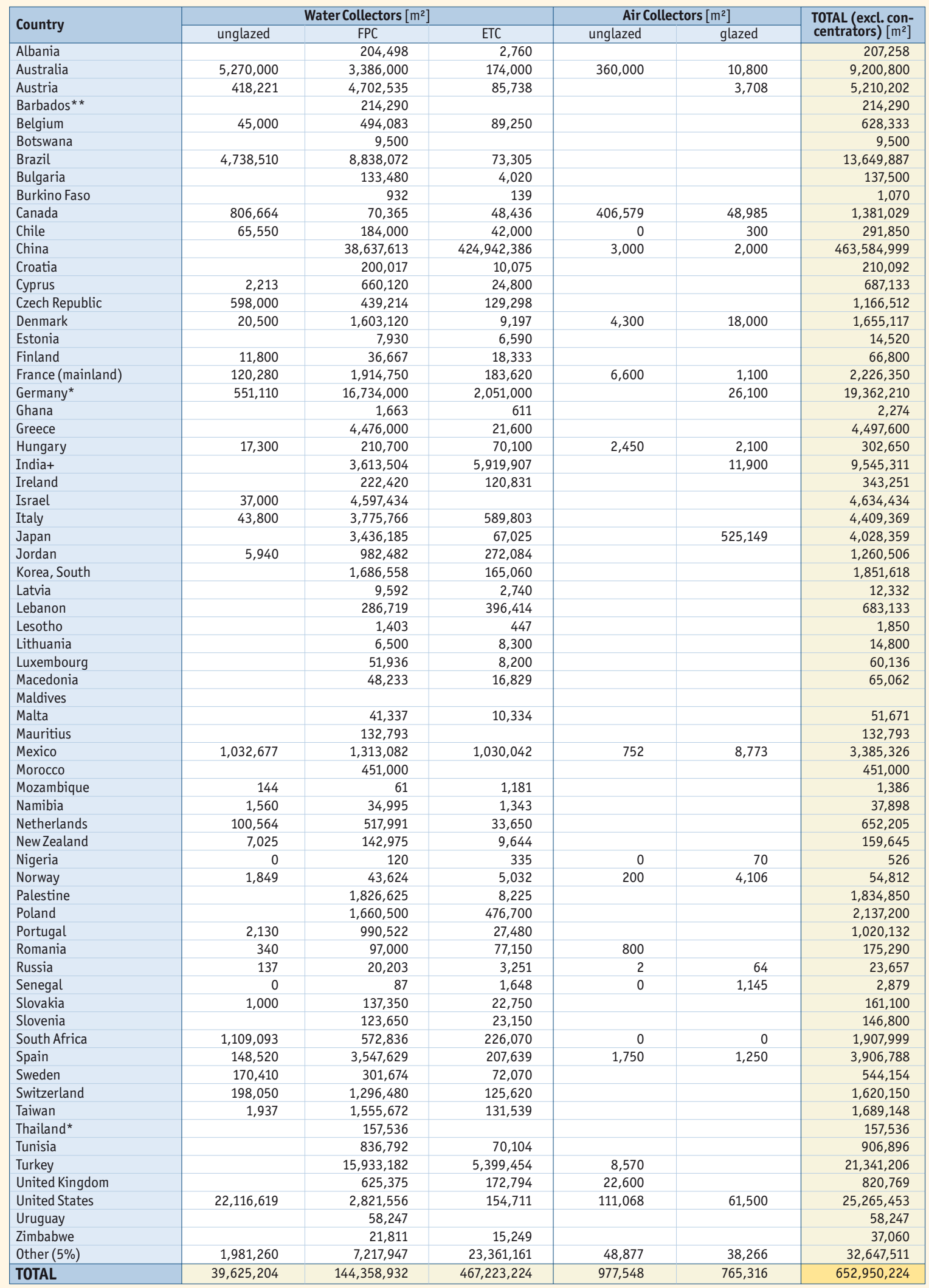

* Revised due to new/adapted database in 2018.

* * Based on Solar Water Heating Techscope Market Readiness Assessment-Reports UNEP 2015.

+ The figures for India refer to the fiscal year April 2015 to March 2016.

Table 18: $\quad$ Total collector area in operation by the end of $2015\left[\mathrm{~m}^{2}\right]$ 
The production of the report, Solar Heat Worldwide - Edition 2018 was kindly supported by national representatives of the recorded countries or other official sources of information as cited below.

\begin{tabular}{|c|c|c|}
\hline COUNTRY & CONTACT & $\begin{array}{l}\text { SOURCE } \\
\text { REMARKS }\end{array}$ \\
\hline Albania & $\begin{array}{l}\text { Dr. Eng. Edmond M. HIDO } \\
\text { EEC - Albania-EU Energy Efficiency Centre (EEC) }\end{array}$ & EEC - Albania-EU Energy Efficiency Centre \\
\hline Australia & $\begin{array}{l}\text { Dr. David Ferrari } \\
\text { Sustainability Victoria }\end{array}$ & $\begin{array}{l}\text { Sustainability Victoria } \\
\text { Out of operation systems calculated by Sustainability Victoria }\end{array}$ \\
\hline Austria & $\begin{array}{l}\text { Werner Weiss } \\
\text { AEE - Institute for Sustainable Technologies }\end{array}$ & $\begin{array}{l}\text { Biermayr et al, 2017: Innovative } \\
\text { Energietechnologien in Österreich - } \\
\text { Marktentwicklung } 2016 \text { (Report in German) } \\
\text { Out ofoperation systems calculated by AEEINTEC }\end{array}$ \\
\hline Barbados & & $\begin{array}{l}\text { Based on Solar Water Heating Techscope Market } \\
\text { Readiness Assessment - Reports, UNEP } 2015 \\
0 \% \text { growth assumed in } 2016\end{array}$ \\
\hline Belgium & $\begin{array}{l}\text { ESTIF - European Solar Thermal } \\
\text { Industry Federation } \\
\text { AEE INTEC }\end{array}$ & $\begin{array}{l}\text { Solar Thermal Markets in Europe - Trends and } \\
\text { Market Statistics 2016, ESTIF } 2017 \\
\text { Glazed water collectors: ESTF, } 2017 \\
\text { Unglazed water collectors: AEEINTEC recordings }\end{array}$ \\
\hline Botswana & $\begin{array}{l}\text { Dr. Edwin Matlotse } \\
\text { Botswana University }\end{array}$ & $0 \%$ growth assumed in 2016 \\
\hline Brazil & $\begin{array}{l}\text { Marcelo Mesquita } \\
\text { ABRASOL - Brazilian Solar Thermal Energy Association }\end{array}$ & $\begin{array}{l}\text { ABRASOL } \\
\text { Out of operation systems calculated based on ABRASOL } \\
\text { long time recordings }\end{array}$ \\
\hline Bulgaria & $\begin{array}{l}\text { ESTIF - European Solar Thermal } \\
\text { Industry Federation } \\
\text { AEE INTEC }\end{array}$ & $\begin{array}{l}\text { Solar Thermal Markets in Europe - Trends and } \\
\text { Market Statistics 2016, ESTIF } 2017 \\
\text { Glazed water collectors: ESTF, 2017 } \\
\text { Unglazed water collectors: AEEINTEC recordings }\end{array}$ \\
\hline Burkina Faso & $\begin{array}{l}\text { Kokouvi Edem N'Tsoukpoe } \\
\text { International Institute for Water and Environmental Engineering } \\
\text { Ouagadougou, Burkina Faso }\end{array}$ & $\begin{array}{l}\text { Rapport de l'étude de marché du solaire } \\
\text { thermique: production d'eau chaude et de } \\
\text { séchage de produits agricoles, } 2015 \\
0 \% \text { growthassumed in } 2016\end{array}$ \\
\hline Canada & $\begin{array}{l}\text { Reda Djebbar, Ph.D., P.Eng. } \\
\text { Natural Resources Canada }\end{array}$ & $\begin{array}{l}\text { Clear Sky Advisors, April } 2017 \text { Report - "Survey } \\
\text { of Active Solar Thermal Collectors, Industry and } \\
\text { Markets in Canada (2016)“ } \\
\text { Out ofoperation systems considered by NRC }\end{array}$ \\
\hline Chile & $\begin{array}{l}\text { Prof. Asistente José Miguel Cardemil } \\
\text { Departamento de Ing. Mecánica, Fac. de Ciencias Físicas y Matemáticas, }\end{array}$ & $\begin{array}{l}\text { www.minenergia.cl/sst/ } \\
\text { Universidad de Chile }\end{array}$ \\
\hline China & $\begin{array}{l}\text { Hu Runqing } \\
\text { Center for Renewable Energy Development- } \\
\text { Energy Research Institute (NDRC) }\end{array}$ & $\begin{array}{l}\text { CSTIF-Chinese Solar Thermal Industry Federation } \\
\text { Out of operation systems calculated by CSIIF }\end{array}$ \\
\hline Croatia & $\begin{array}{l}\text { ESTIF - European Solar Thermal } \\
\text { Industry Federation }\end{array}$ & $\begin{array}{l}\text { Solar Thermal Markets in Europe - Trends and } \\
\text { Market Statistics 2016, ESTIF } 2017 \\
\text { Glazed water collectors: ESTIF, } 2017\end{array}$ \\
\hline
\end{tabular}


Cyprus

Panayiotis Kastania

Soteris Kalogirou

Cyprus University of Technlolgy
Cyprus Employers and Industrialists Federation

http://www.ebhek.org.cy/wp-content/ uploads/2018/01/Cyprus-Solar-ThermalMarket-Analysis-EBHEK-2014-20152016.pdf

Newinstallations 2016: EBHEK SolarThermal Market Analysis 2014-2016

Cumulated calculated by AEEINTEC

\begin{tabular}{lll}
\hline Czech Republic & $\begin{array}{l}\text { Ales Bufka } \\
\text { Ministry of Industry and Trade }\end{array}$ & Ministry of Industry and Trade \\
\hline Denmark & $\begin{array}{l}\text { ESTIF - European Solar Thermal } \\
\text { Industry Federation }\end{array}$ & $\begin{array}{l}\text { Solar Thermal Markets in Europe - Trends and } \\
\text { Market Statistics 2016, ESTIF 2017 } \\
\text { Unglazed water collectors: AEEINTEC recordings }\end{array}$ \\
& AEE INTEC & \\
& $\begin{array}{l}\text { Jan-Erik Nielsen } \\
\text { Planenergi }\end{array}$ & \\
\hline ESTIF - European Solar Thermal & Industry Federation & $\begin{array}{l}\text { Solar Thermal Markets in Europe - Trends and } \\
\text { Market Statistics 2016, ESTIF 2017 }\end{array}$ \\
\hline Finland & Gille Maljanen & Solar Energy Statistics Finland \\
Solar Energy Statistics Finland & $\begin{array}{l}\text { Expert Estimation } \\
\text { Observ'ER - Observatoire des énergies renouvelables }\end{array}$ & $\begin{array}{l}\text { Observ'ER 2017, data provided by Frédéric Tuillé } \\
\text { Aircollectors: John Hollick }\end{array}$
\end{tabular}

\section{Paul KAAIJK}

Agence de l'Environnement et de la Maîtrise de l'Énergie (ADEME)

\section{John Hollick}

SAHWIA - Solar Air Heating World Industry Association

\begin{tabular}{|c|c|c|}
\hline Germany & $\begin{array}{l}\text { Marco Tepper } \\
\text { BSW - Bundesverband Solarwirtschaft e.V. } \\
\text { John Hollick } \\
\text { SAHWIA - Solar Air Heating World Industry Association }\end{array}$ & $\begin{array}{l}\text { BSW - Bundesverband Solarwirtschaft e.V. } \\
\text { Air collectors: SAHWIA } \\
\text { FPC/ETC: BSW solar long time recordings; unglazed water collectors \& } \\
\text { glazed air collectors: recordings AEE INTEC }\end{array}$ \\
\hline Ghana & $\begin{array}{l}\text { Divine Atsu } \\
\text { Koforidua Polytechnic, Department of } \\
\text { Energy Systems Engineering }\end{array}$ & $\begin{array}{l}\text { Data provided by Divine Atsu } \\
0 \% \text { growthassumed in } 2016\end{array}$ \\
\hline Greece & $\begin{array}{l}\text { Costas Travasoras (EBHE) } \\
\text { AEE INTEC }\end{array}$ & $\begin{array}{l}\text { Costas Travasoras (EBHE) } \\
\text { Solar Thermal Markets in Europe - Trends and } \\
\text { Market Statistics 2016, ESTIF } 2017 \\
\text { Newinstallations: ETC/FPC by ESTIF; Costas TRAVASAROS (EBHE) } \\
\text { Cumulated installations: cumulated area: ESTIF 2017/ share FPC-ETC: } \\
\text { AEEINTEC }\end{array}$ \\
\hline Hungary & $\begin{array}{l}\text { Pál Varga } \\
\text { MÉGNAP - Hungarian Solar Thermal Industry Federation }\end{array}$ & $\begin{array}{l}\text { MÉGNAP - Hungarian Solar Thermal Industry } \\
\text { Federation } \\
\text { Newand cumulated installations: Hungarian SolarThermalIndustry } \\
\text { Federation (MÉGNAP); provided by PálVarga (personal estimation) }\end{array}$ \\
\hline India & $\begin{array}{l}\text { Jaideep N. Malaviya } \\
\text { Malaviya Solar Energy Consultancy }\end{array}$ & $\begin{array}{l}\text { Malaviya Solar Energy Consultancy (based on } \\
\text { market survey) } \\
\text { Newand cumulated installations based on survey from Malaviya Solar } \\
\text { Energy Consultancy; out of operation systems considered in } 2016 \text { re- } \\
\text { corded data changed from fiscal to calendaryear }\end{array}$ \\
\hline
\end{tabular}


Ireland Mary Holland

Sustainable Energy Authority of Ireland
Energy policy statistical support unit of Sustainable Energy Authority of Ireland

Grantscheme data; BER database: Source: Energy policystatistical supportunit of Sustainable Energy Authority of Ireland; provided by Mary Holland

$\begin{array}{ll}\text { Israel } & \begin{array}{l}\text { Eli Shilton } \\ \text { ELSOL }\end{array} \\ & \begin{array}{l}\text { Bärbel Epp } \\ \text { Solrico - Solar market research, http://www }\end{array} \\ & \begin{array}{l}\text { ESTIF - European Solar Thermal } \\ \text { Industry Federation }\end{array}\end{array}$

AEE INTEC

ELSOL (Eli Shilton), data provided by Bärbel Epp Cumulated collector area calculated by AEEINTEC based on new installation and replacementfigures from EliShilton (ELSOL)

Solar Thermal Markets in Europe - Trends and Market Statistics 2016, ESTIF 2017

Cumulated area: ESTIF 2017 / share FPC-ETC: AEEINTEC / unglazed watercollectors: AEEINTEC

Japan

EurObservEr 2017

Solar System Development Association (SSDA) Share FPC/ETCAEEINTEC

Jordan AEE INTEC

Korea, South Eunhee Jeong

Korea Energy Management Corporation (KEMCO)

Latvia ESTIF - European Solar Thermal Industry Federation

AEE INTEC

Newinstallations: no new collectors for 2016 Cumulated installations by end of 2014

2016 New \& Renewable Energy Statistics by the Korea New \& Renewable Energy Center, 2017

Solar Thermal Markets in Europe - Trends and Market Statistics 2016, ESTIF 2017

Glazed water collectors: ESTF, 2017 (estimation)

\begin{tabular}{ll} 
Lebanon & $\begin{array}{l}\text { Tony Gebrayel } \\
\text { Lebanese Center for Energy Conservation (LCEC) }\end{array}$ \\
\hline Lesotho & $\begin{array}{l}\text { Bethel Business and Community } \\
\text { Development Center (BBCDC) }\end{array}$ \\
\hline Lithuania & $\begin{array}{l}\text { ESTIF - European Solar Thermal } \\
\text { Industry Federation }\end{array}$
\end{tabular}
Industry Federation

Luxembourg ESTIF - European Solar Thermal Industry Federation

Lebanese Center for Energy Conservation (LCEC) Cumulated calculated by AEEINTEC

SOLTRAIN Study, Data provided by Puleng Mosothoane

Solar Thermal Markets in Europe - Trends and Market Statistics 2016, ESTIF 2017

Glazed water collectors: ESTF, 2017 (estimation)

Solar Thermal Markets in Europe - Trends and Market Statistics 2016, ESTIF 2017

Glazed water collectors: ESTF, 2017 (estimation)

\section{Macedonia $\quad$ Prof. Dr. Ilja Nasov}

National University St. Kiril and Metodij, Faculty for Natural Science, Institute of Physics, Solar Energy Department

2016 data estimation of Ilya Nasov and other solar experts

Newinstallations: estimation of Ilya Nasovand other solar experts;

Cumulated installations: calculated by AEEINTEC based on newinstallation figures

$\begin{array}{ll}\text { Malta } & \text { Ing. Therese Galea } \\ \text { Sustainable Energy and Water Conservation Unit (SEWCU) }\end{array}$

Sustainable Energy and Water Conservation Unit (SEWCU) based on data provided by the Ministry for Energy and Health

$\begin{array}{ll}\text { Mauritius } & \text { Mrs Devika Balgobin } \\ & \text { Statistician } \\ & \text { Environment Statistics Unit, Ministry of Environment } \\ & \text { and Sustainable Development }\end{array}$
Regulator for Energy and Water Services (REWS)

Statistics Mauritius

No new collector area 2016; cumulated collector area by end of 2015 and Sustainable Development

$\begin{array}{ll}\text { Mexico } & \text { David Garcia } \\ & \text { FAMERAC }\end{array}$

\section{Bärbel Epp}

Solrico - Solar market research, http://www.solrico.com/
Glazed and unglazed water collectors: FAMERAC - Renewable Energy Industry Associationdata provided by Bärbel Epp Air collectors: SAHWIA - Solar Air Heating World Industry Association Cumulated installations: calculated by AEEINTEC 
Morocco

Ashraf Kraidy

RECREEE - Regional Center for Renewable Energy and

No new collector area 2016; cumulated collector area by end of 2014

Energy Efficiency

\begin{tabular}{lll} 
Mozambique & $\begin{array}{l}\text { Fabião Cumbe } \\
\text { ENPCT, E.P. }\end{array}$ & $\begin{array}{l}\text { Estimation provided by Fabião Cumbe } \\
\text { Cumulated installations calculated by AEEINTEC based on new } \\
\text { installation figures for 2016 }\end{array}$ \\
\hline Namibia & ZEE INTEC & $\begin{array}{l}2014-2016 \text { survey provided by Zivayi Chiguvare } \\
\text { Namibian Energy Institute, Namibia University of Science and Technology }\end{array}$ \\
\hline Netherlands & $\begin{array}{l}\text { André Meurink, Reinoud Segers } \\
\text { Statistics Netherlands (CBS) }\end{array}$ & $\begin{array}{l}\text { Statistics Netherlands (CBS) } \\
\text { Newlyinstalled areas: Statistics Netherlands based on survey of sales. } \\
\text { Market Shares: Expertestimates Netherlands Enterprise Agencyand } \\
\text { Holland Solar. }\end{array}$ \\
\hline New Zealand & $\begin{array}{l}\text { No data available since } 2010 \\
\text { Cumulated area in } 2009\end{array}$
\end{tabular}

$\begin{array}{ll}\text { Nigeria } & \text { National Centre for Energy Research and } \\ \text { Development, University of Nigeria, } \\ \text { Nsukka }\end{array}$

National Centre for Energy Research and Development, University of Nigeria, provided by Okala Nwoke

Norway

2015 data projected by AEEINTEC

(0\% growth rate 2015/2016 assumed)

Palestinian Territories Mohammed Mobayyed

EEU Director, Palestinian Energy Authority

Poland Janusz Staroscik- President

Association of Heating Appliances manufacturers and

Importers in Poland

Portugal ESTIF - European Solar Thermal Industry Federation

ESTIF - European Solar Thermal Industry Federation

Romania

$\begin{array}{ll}\text { Russia } & \text { Dr. Semen Frid, Dr. Sophia Kiseleva } \\ \text { Moscow State University }\end{array}$

Prof. Vitaly Butuzov

Yuzhgeoteplo corporation, Krasnodar

Senegal

Université Cheikh Anta DIOP
Palestinian Energy Authority

$0 \%$ growth assumed in 2016, Cumulated area calculated by AEEINTEC (replacements not considered)

Solar Thermal Markets in Europe - Trends and Market Statistics 2016, ESTIF 2017

Solar Thermal Markets in Europe - Trends and Market Statistics 2016, ESTIF 2017

Glazed water collectors: ESTIF, 2017 (estimation)

Solar Thermal Markets in Europe - Trends and Market Statistics 2016, ESTIF 2017

Glazed water collectors: ESTIF, 2017 (estimation)

Joint Institute for High Temperatures of Russian Academy of Scienses (JIHT RAS) Dr. Semen Frid, Sophia Kiseleva - Moscow State University, Vitaly Butuzov - Energytechnologies Ltd. (Krasnodar); the source of information-JIHT RAS

Rapport de Merché du Solaire Thermique: Production d'Eau Chaude et Séchage de Produits Agricoles: provided by T. Ababacar

0\% growthassumed 2016

Slovakia

ESTIF - European Solar Thermal Industry Federation

Solar Thermal Markets in Europe - Trends and Market Statistics 2016, ESTIF 2017 Glazed water collectors: ESTIF, 2017 (estimation)

Slovenia University of Ljubljana, Faculty of Mechanical Engineering

\section{ESTIF - Europe}

University of Ljubljana, Faculty of Mechanical Engineering;Eco Fund, Slovenian Environmental Public Fund; provided by Ciril Arkar

\section{Karin Kritzinger}

Centre of Renewable and Sustainable Energy Studies University of Stellenbosch
Department of Energy, SESSA, Stellenbosch University, Solco, GIZ, Sanedi, City of Cape Town Metro; provided by Karin Kritzinger 
Spain

Pascual Polo

ASIT - Asociación Solar de la Industria Térmica

Prof.Jan-Olof Dalenbäck

Svensk Solenergi / CHALMERS

http://www.swissolar.ch/
ASIT (Solar Energy Industry Association of Spain)

Out of operation systems calculated by AST

Svensk solenergi (Solar Energy Association of Sweden)

SWISSOLAR - Markterhebung Sonnenenergie 2016, Bundesamt für Energie 2017

Out of operation systems calculated by SWISSOLAR

Taiwan

K.M. Chung

Energy Research Center - National Cheng Kung University

Bureau of Energy, Ministry of Economic Affairs, R.O.C.

Out of operation systems calculated by Bureau of Energy, Ministry of Economic Affairs, R.O.C.

Thailand Charuwan Phipatana-phuttapanta Department of Alternative Energy Development and Efficiency (DEDE), Ministry of Energy

GIZ study, Department of Alternative Energy Development and Efficiency (DEDE), Ministry of Energy (Subsidized systems) Data for subsidized systems, provided by Charuwan Phipatanaphuttapanta, single-family houses estimated by AEEINTEC based on GIZstudy

\begin{tabular}{|c|c|c|}
\hline Tunisia & $\begin{array}{l}\text { Abdelkader Baccouche } \\
\text { Agence Nationale pour la Maîtrise de l'Energie (ANME) }\end{array}$ & ANME (National Agency of Energy Conservation) \\
\hline Turkey & $\begin{array}{l}\text { A. Kutay Ulke } \\
\text { Bural Heating Corporation Ltd. } \\
\text { John Hollick } \\
\text { SAHWIA - Solar Air Heating World Industry Association } \\
\text { Prof. Bulent Yesilata } \\
\text { GAP Renewable Energy and Energy Efficiency Center Harran University }\end{array}$ & $\begin{array}{l}\text { Water collectors: A. Kutay Ulke, personal studies } \\
\text { Air collectors: SAHWIA } \\
\text { Newinstallations: A. Kutay Ulke } \\
\text { Cumulated installations: calculated by AEEINTEC } \\
\text { considering } 14 \text { years lifetime } \\
\text { Shares provided by BulentYesilata (2016) }\end{array}$ \\
\hline United Kingdom & $\begin{array}{l}\text { Lethbridge Yehuda } \\
\text { Department of Energy and Climate Change } \\
\text { John Hollick } \\
\text { SAHWIA - Solar Air Heating World Industry Association }\end{array}$ & $\begin{array}{l}\text { UK Solar Trade Association and ESTIF Reports } \\
\text { collated in BEIS annual survey Active Solar } 2016 \\
\text { survey, provided by Yehuda Lethbridge, } \\
\text { air collectors provided by John Hollick } \\
\text { Cumulated ESTIF 2017; FPC/ETC calculated by AEEINTEC; air collectors } \\
\text { provided by John Hollick }\end{array}$ \\
\hline United States & $\begin{array}{l}\text { Les Nelson } \\
\text { IAPMO Solar Heating \& Cooling Programs } \\
\text { John Hollick } \\
\text { SAHWIA - Solar Air Heating World Industry Association }\end{array}$ & $\begin{array}{l}\text { Water Collectors and air collectors: IAPMO Solar } \\
\text { Heating \& Cooling Programs; } \\
\text { Air collectors: SAHWIA } \\
\text { Newinstallations: DOE/SEIA/IAPMO; Totals: calculated by AEEINTEC } \\
\text { considering } 25 \text { years lifetime }\end{array}$ \\
\hline Uruguay & Ministry of Industry, Energy and Mining & $\begin{array}{l}\text { Ministry of Industry, Energy and Mining, pro- } \\
\text { vided by Martín Scarone } \\
0 \% \text { growth rate assumed 2015/2016 }\end{array}$ \\
\hline Zimbabwe & $\begin{array}{l}\text { Samson Mhlanga } \\
\text { National University of Science and Technology, Bulawayo }\end{array}$ & $\begin{array}{l}\text { Dr. Anton Schwarzlmüller } \\
\text { Domestic Solar Heating unpublished statistics } \\
\text { SOLTRAIN survey (unpublished sources) } \\
\text { cumulated } 2016 \text { calculated by AEEINTEC }\end{array}$ \\
\hline
\end{tabular}




\section{Additional literature and web sources used}

The following reports and statistics were used in this report:

- Bundesamt für Energie (BFE): Markterhebung Sonnenenergie 2016 - Teilstatistik der Schweizerischen Statistik der erneuerbaren Energien; prepared by SWISSOLAR, Thomas Hostettler, Bern, Switzerland July 2017

- Bundesministerium für Verkehr, Innovation und Technologie (BMVIT): Innovative Energy Technologies in Austria - Market Development 2016; prepared by Peter Biermayr et al, Vienna, Austria June 2017

- Bundesverband Solarwirtschafte.V. (BSW-Solar):StatistischeZahlen der deutschen Solarwärmebranche (Solarthermie) 2016; accessed October 2017

- ClearSky Advisors Inc.: Survey of Active Solar Thermal Collectors, Industry and Markets in Canada (2016); Prepared by ClearSky Advisors Inc., Dr. Reda Djebbar, Natural Resources Canada, March 2017

- European Solar Thermal Industry Federation (ESTIF): Solar Thermal Markets in Europe, Trends and Market Statistics 2016; Belgium - Brussels; November 2017

- IRENA: Renewable Energy and Jobs: Annual Review 2016

- Weiss, W. (2003) Wirtschaftsfaktor Solarenergie, Wien

- Weiss, W., Biermayr, P. (2006) Potential of Solar Thermal in Europe, published by ESTIF

- Lehr, U. et.al (2015) Beschäftigung durch erneuerbare Energien in Deutschland: Ausbau und Betrieb, heute und morgen

The following online sources were used in this report:

- http://www.anes.org/anes/index.php

- http://www.asit-solar.com/

- http://www.solarpowereurope.org/home/

- http://www.iea-shc.org/

- http://www.mnre.gov.in/

- http://www.olade.org/

- http://sahwia.org/

http://www.solarwirtschaft.de/

http://www.solarthermalworld.org/
- http://www.aderee.ma/

- http://www.dasolabrava.org.br/

- http://www.giz.de/

- http://www.irena.org/

- http://www.ome.org/

- http://www.ren21.net/

- http://www.solar-district-heating.eu/

- http://www.solrico.com/

- http://www.swissolar.ch/

\section{9 \\ List of Figures}

Figure 1: $\quad$ From countries shown in color detailed market data are available. The market data from countries shown in grey the data are estimated. $\quad . . . . . . . \quad 4$

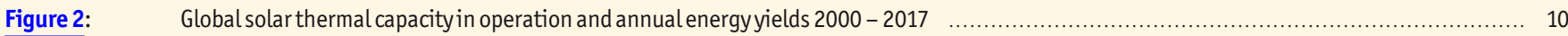

Figure 3: $\quad$ Global capacity in operation $\left[\mathrm{GW}_{\mathrm{el}}\right],\left[\mathrm{GW}_{\mathrm{th}}\right] 2017$ and annual energyyields [TWh $\mathrm{el},\left[\mathrm{TWh}_{\mathrm{th}}\right]$

(Sources: AEE INTEC, Global Wind Energy Council (GWEC), European PVIndustry Association (EPIA), REN21 - Global Status Report 2018)

Figure 4: $\quad$ Global solar thermal heat, wind power and photovoltaic capacity in operation and market growth rates between 2010 and 2017 (Sources: AEE INTEC, Global Wind Energy Council (GWEC), European PVIndustry Association (EPIA), REN21 - Global Status Reports 2011 - 2018) ... 12

Figure 5: $\quad$ Large-scale systems for solar district heating and large residential, commercial and public buildings worldwide - annual achievements and cumulated area in operation in 2017

(Data source: Jan-Olof Dalenbäck-Chalmers University of Technology, SE and Sabine Putz-IEA SHCTask 55, Bärbel Epp solarthermalworld.org) .... 14 
Figure 6: Large-scale systems for solar district heating and residential buildings - capacities and collector area installed and number of systems in 2017 (Data source: Jan-Olof Dalenbäck-Chalmers University of Technology, SE and Sabine Putz-IEA SHCTask55, Bärbel Epp solarthermalworld.org) $\quad \ldots \quad 15$

Figure 7: Solar districtheating systems $>500 \mathrm{~m}^{2}(>350 \mathrm{~kW}$ th) in Europe. (Source: Heat Roadmap Europe)

Figure 8: $\quad$ Share of concentrating and non-concentrating collector systems in India, Mexico and the rest of the world by end of March 2018. The inner ring shows the share of concentrating collector systems. The outer ring shows the share of non-concentrating collector systems.

(Source: IEA SHCTask49/IVSHIP database)

Figure 9: $\quad$ Number and gross area of installed plants with concentrating collectors in India and Mexico by end of March 2018.

(Source: IEA SHCTask49/IVSHIP database)

Figure 10:

Application of concentrating collectors to various industrial sectors in India and Mexico by end of March 2018.

(Source: IEA SHCTask49/IVSHIP database)

Figure 11: Number, gross area and thermal capacity of installed plants with concentrating collector types in different size categories in Mexico by end of March 2018. (Source: IEA SHCTask49/IVSHIP database)

Figure 12: $\quad$ Number, gross area and thermal capacity of installed plants with concentrating collector types in different size categories in India by end of March 2018. (Source: IEA SHCTask49/IVSHIP database)

Figure 13: Global solar process heat plants in operation by capacity and collector area by end of March 2018, (Source: IEA SHC Task49/IVSHIP database) $\quad \ldots \quad 27$

Figure 14:

Figure 15: Global solar process heat applications in operation by type of collector by end of March 2018. (Source: IEA SHCTask49/IVSHIP database) $\quad . . . . . . . .28$

Figure 16: Global solar process heat applications in operation by industry sector by end of March 2018. (Source: IEA SHCTask49/IVSHIP database) $\quad \ldots \ldots \ldots . . .28$ Global solar process heat applications in operation by country by end of March 2018. Only countries with at least $0.7 \mathrm{MW}_{\text {th }}$

(1,000 $\mathrm{m}^{2}$ gross area) are shown (248 of 271 systems accounting for $98 \%$ of installed thermal capacity)

Figure 17: Specific useful heat delivery and latitude of installed systems by end of March 2018 (Source: IEA SHC Task49/IVSHIP database) Share of the total installed capacity in operation (glazed and unglazed water and air collectors) by economic region in 2016

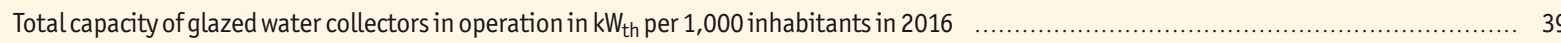
Solar thermal market penetration per capita worldwide in $\mathrm{kW}_{\text {th }}$ per 1,000 inhabitants

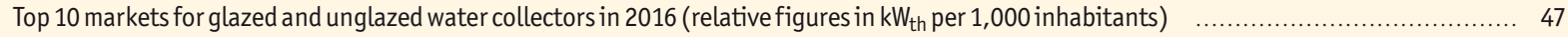

Figure 37: Newly installed capacity of glazed water collectors in 2016 
Figure 57: Distribution of solar thermal systems by application for the newly installed water collector capacity by economic region in 2016 domestic systems, green: large-scale commercialapplications)

Figure 58: $\quad$ Specific Investment costs and levelized costs of solar thermal generated heat for small pumped domestic hot water systems $\quad \ldots \ldots \ldots \ldots \ldots \ldots \ldots . . . . . . . .66$

Figure 59: $\quad$ Specific Investment costs and levelized costs of solar thermal generated heat for small thermosiphon domestic hot water systems $\quad \ldots \ldots \ldots \ldots \ldots . . . . .67$

Figure 60: $\quad$ Specific Investment costs and levelized costs of solar thermal generated heat for large pumped domestic hot water systems $\quad \ldots \ldots \ldots \ldots \ldots \ldots \ldots . . . . . . . . .68$

Figure 61: Specific Investment costs and levelized costs of solar thermal generated heat for small combined hot water and space heating systems .......... 69

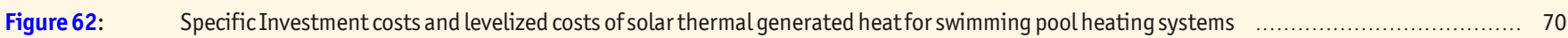

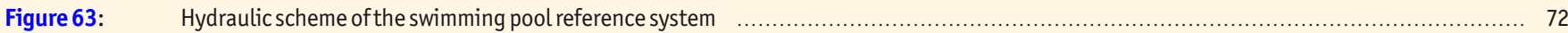

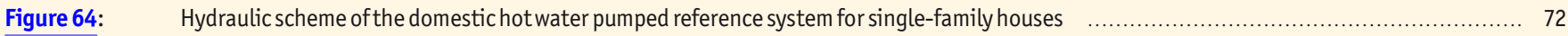

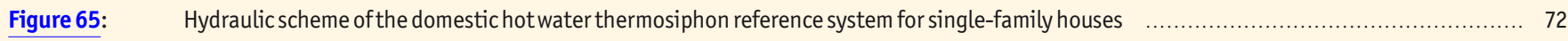

Figure 66: Hydraulic scheme of the domestic hot water pumped reference system for multifamily houses _................................................. 75

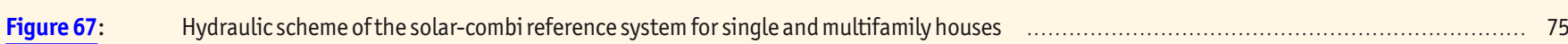

\section{$9.10 \quad$ List of Tables}

Table 1: $\quad$ SHIP plants installed in 2017 Sources: Solar Payback SHIP Supplier Survey 2017 and AEE INTEC _............................................. 21

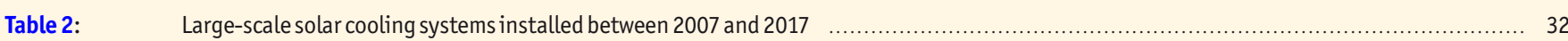

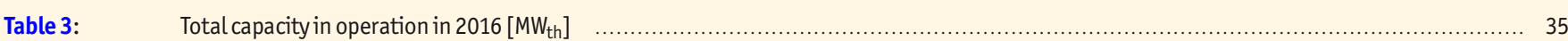

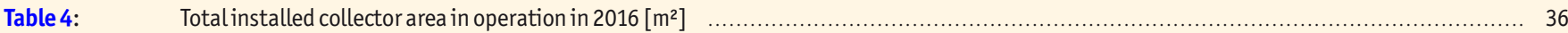

Table 5: $\quad$ Calculated annual collector yield and corresponding oil equivalent and $\mathrm{CO}_{2}$ reduction of glazed and unglazed water collectors

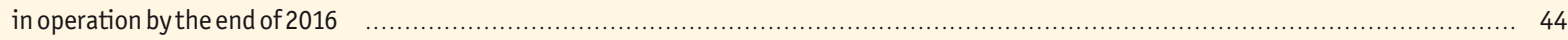

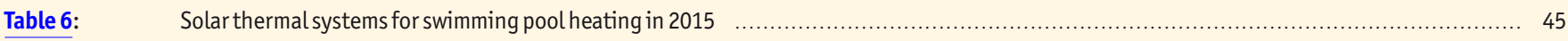

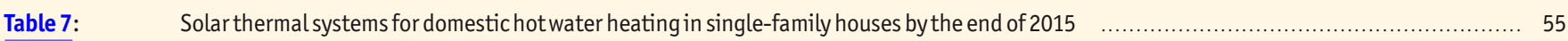

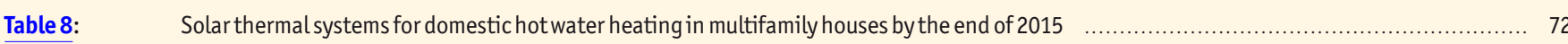

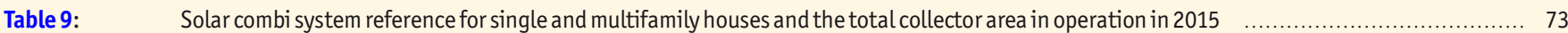

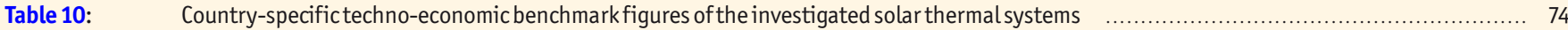

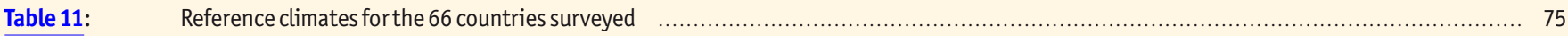

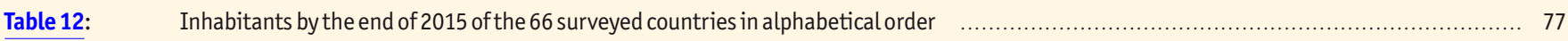

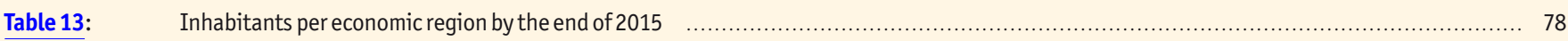

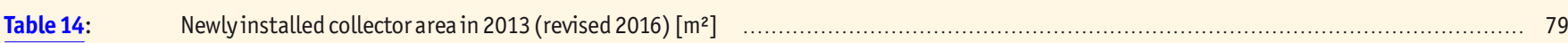

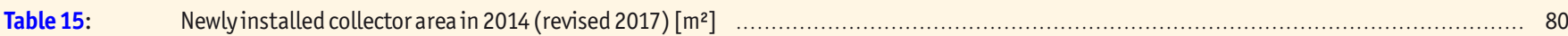

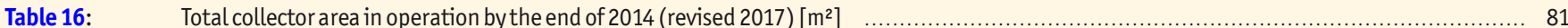


